\author{
UNIVERSIDADE DE SÃO PAULO \\ FACULDADE DE FILOSOFIA, LETRAS E CIÊNCIAS HUMANAS \\ DEPARTAMENTO DE LETRA ORIENTAIS \\ PROGRAMA DE LINGUA HEBRAICA, LITERATURA E CULTURA \\ JUDAICAS
}

São Paulo

2005 
“Não sou judeu nem cristão, mas ambos ao mesmo tempo. Não rezo no templo nem na igreja, só no velho Muro das Lamentações."

\section{Eric Brill}

(pintor e viajante, nascido em 1895 em Luebeck, Alemanha, viveu no Brasil entre 1934 e 1936 e morreu fuzilado em 1942 no Campo de Concentração de Jungfernhof) 
Agradecimentos:

A todos que colaboraram direta ou indiretamente na realização desta dissertação, em especial a Berta e Ada pelo carinho com que me receberam e acolheram no Departamento e a Rita pela paciência e disposição. 


\section{1 - ÍNDICE}

1 - ÍNDICE

2 - RESUMO

$\begin{array}{ll}3 \text { - ABSTRACT } & 7\end{array}$

4 - PALAVRAS CHAVES/KEY WORDS 8

4.1 - Palavras chaves: Gilberto Freyre, imigração, judeu, literatura, preconceito. $\quad 8$

$\underline{4.2-\text { Key words: Gilberto Freyre, immigration, jewish, literature, prejudice. }} \quad 8$

$\underline{5 \text { - INTRODUÇÃO }} \quad 9$

6 - OBJETIVO DA PESQUISA

7 - METODOLOGIA DE PESQUISA

7.1 Delimitação do período: $\quad 16$

$\begin{array}{ll}7.2 \text { Escolha dos autores e das obras que serão estudadas: } & 16\end{array}$

7.3 Análise do texto: 17

\begin{tabular}{ll}
\hline 7.4 Conclusão: & 18
\end{tabular}

8 - SÍNTESE DA PRESENCA JUDAICA NO BRASIL $\quad 19$

$\begin{array}{ll}\text { 8.1 OS REFLEXOS NA LITERATURA } & 37\end{array}$

9 - OS JUDEUS EM GILBERTO FREYRE

$\begin{array}{ll}9.1 \text { QUEM FOI GILBERTO FREYRE? } & 45\end{array}$

$\begin{array}{ll}\text { 9.2 A OBRA DE GILBERTO FREYRE } & 50\end{array}$

9.3 MANIFESTO REGIONALISTA - 1926

9.4 CASA GRANDE \& SENZALA E SOBRADOS E MUNCAMBOS

9.4.1 FREYRE E O USO NEGATIVO DA IMAGEM DO JUDEU EM CASA GRANDE \& SENZALA E SOBRADOS E MUCAMBOS $\quad 59$

9.4.2 FREYRE E A VISÃO POSITIVA DOS JUDEUS EM CASA GRANDE \& SENZALA E SOBRADOS E

$\begin{array}{ll}\text { MUCAMBOS } & 65\end{array}$

9.5 O VELHO FÉLIX E SUAS MEMÓRIAS DE UM CAVALCANTI

9.6 OS GUIAS PRÁTICOS, HISTÓRICOS E SENTIMENTAIS DE CIDADES BRASILEIRAS 76

$\begin{array}{ll}\text { 9.7 DEMAIS OBRAS DE FREYRE NO PERÍODO } & 78\end{array}$

9.8 A ESCOLA DE FREYRE E SEUS DISCÍPULOS 
11- BIBLIOGRAFIA 


\section{2 - RESUMO}

Através do levantamento de obras, escritas entre 1920 e 1940, foi elaborada a pesquisa, que procura identificar elementos e personagens que compõem o judaísmo e/ou à cultura judaica. Paralelamente à pesquisa bibliográfica, também são estudadas as obras escritas por Gilberto Freyre no período, procurando-se visualizar o ponto de vista do autor sobre os judeus na história do Brasil.

Para uma melhor compreensão da pesquisa e da obra de Freyre, foi traçado um panorama histórico da presença judaica no Brasil e da literatura brasileira a partir dos movimentos modernista e regionalista. 


\section{3 - ABSTRACT}

This research was developed through a survey of works which were written between 1920 and 1940. It aims to identify elements and characters that belong to the Judaism or to the Jewish culture. At the same time, it covers the works written by Gilberto Freyre in the same period by analyzing the author's point of view on the Jewish participation in the Brazilian history.

In order to better understand the research and Freyre's works, it was presented the picture of the presence of the jews in Brazil as well as the Brazilian literature (considering the "Modernism" and "Regionalism" as starting points). 


\section{4 - PALAVRAS CHAVES/KEY WORDS}

4.1 - Palavras chaves: Gilberto Freyre, imigração, judeu, literatura, preconceito.

4.2 - Key words: Gilberto Freyre, immigration, jewish, literature, prejudice. 


\section{5 - INTRODUÇÃO}

"A literatura e a arte não pertencem apenas ao domínio da crítica literária ou da arte: incidem também no domínio do sociólogo, do historiador social, do antropólogo e do psicólogo social. Porque através da literatura e da arte é que os homens parecem mais projetar a sua personalidade, e, através da personalidade, o seu éthos nacional. Através das artes eles descrevem as condições mais angustiosas do meio em que vivem e refletem os seus desejos mais revolucionários. $E$ ainda, através das artes, exprimem os aspectos mais particularmente oprimidos, tanto como os mais vigorosamente dinâmicos, da sua personalidade e do seu éthos nacional." ${ }^{1}$

A análise textual funciona como suporte para a historiografia literária. A história, a sociologia, a psicologia e as ciências sociais em geral podem se beneficiar do estudo do texto literário. O conjunto das obras de Balzac, por exemplo, exibe verdadeiros tratados de psicologias individuais, constituindo um documento da sociedade francesa, que pode ser útil por permitir uma visão global do que ela foi no século XIX.

Desse modo, através da literatura, podemos obter informações importantes que retratam e corroboram momentos históricos e simbólicos de uma sociedade, de uma cultura e de um povo.

Aldous Huxley, em sua obra Texts and Pretexts, afirma que "em grande parte, as nações são inventadas pelos seus poetas e novelistas". Adotando este mesmo pensamento, Teixeira Soares, estudioso de Machado de Assis, diz: "Machado de Assis , em grande parte, inventou a vida do Rio de Janeiro durante o Império".. ${ }^{2}$

A literatura brasileira também constitui uma importante fonte documental, retratando momentos sociais e históricos desde os idos do Brasil colônia até os dias atuais. No princípio, nossa literatura estava fortemente atrelada a Portugal e, aos poucos, foi

\footnotetext{
${ }^{1}$ FREYRE, Gilberto. Interpretações do Brasil: aspectos da formação social brasileira como processo de amalgamento de raças e culturas; tradução Olívio Montenegro. São Paulo, Cia. das Letras, 2001. Pág. 281.

${ }^{2}$ SOARES, Teixeira. Machado de Assis(ensaio e interpretação), Rio de Janeiro, Typ. Guido \& Cia., 1936.
} 
adquirindo suas características nacionais, distanciando-se da metrópole e percorrendo um caminho próprio, que transcorreu paralelamente aos momentos históricos e sociais brasileiros.

Segundo Antonio Cândido, num romance o que há de mais vivo é a personagem e a leitura do texto depende basicamente da aceitação da verdade da personagem por parte do leitor: "A personagem é um ser fictício, - expressão que soa como paradoxo. De fato, como pode uma ficção ser? Como pode existir o que não existe? No entanto, a criação literária repousa sobre este paradoxo, e o problema da verossimilhança no romance depende desta possibilidade de um ser fictício, isto é, algo que, sendo uma criação da fantasia, comunica a impressão da mais lídima verdade existencial. Podemos dizer, portanto, que o romance se baseia, antes de mais nada, num certo tipo de relação entre o ser vivo e o ser fictício, manifestada através da personagem, que é a concretização deste." 3

No contexto histórico, estudos demonstram que a presença judaica no Brasil remonta ao período colonial e ao período das grandes navegações. Numerosos judeus fugindo da Inquisição se refugiaram na distante e exótica colônia de Portugal. Cripto-judeus desenvolveram comunidades secretas, apesar dos visitadores da Inquisição, dos processos que sofreram, das prisões e até da pena capital.

Durante o período de dominação holandesa, sob o comando do Conde Maurício de Nassau, a comunidade judaica que existiu em Recife conseguiu atingir considerável desenvolvimento sócio-econômico e cultural, em uma época de liberdade, em que a igreja católica não podia interferir. Porém, quando da retomada de Recife pelos portugueses, esta mesma comunidade foi forçada a emigrar. Durante os séculos XVII e XVIII, não há notícias de ondas imigratórias de população judaica e aqueles que ficaram esconderam sua fé e suas origens, pois este era o princípio básico para se manter vivo e em liberdade.

Com o estabelecimento do império no século XIX, surgiram pequenos núcleos de imigrantes judeus na região norte do Brasil, concomitantes com o ciclo da borracha. Tais núcleos eram compostos por judeus marroquinos ou norte-africanos em geral,

\footnotetext{
${ }^{3}$ CÂNDIDO, Antonio. A personagem do romance, in A personagem de ficção. São Paulo, Perspectiva, 2000.
} 
mas somente no final da década de 20 do século passado é que a imigração judaica começa a ser visível socialmente.

Esta visibilidade da imigração passa a ser retratada na literatura brasileira através de personagens que começam a povoar o caldeirão social brasileiro. O judeu passa a conviver lado a lado com italianos, portugueses, espanhóis, alemães, sírios, libaneses e muitos outros imigrantes que aqui aportaram.

Vejamos, por exemplo, dois trechos do conto O Ingênuo Dagoberto (Seu Dagoberto Piedade), de Antonio de Alcântara Machado, que faz parte do livro Laranja da China, publicado a primeira vez em 1928:

"Diante da porta da loja pararam. Seu Dagoberto carregava o menorzinho. Silvana a maleta das fraldas. Nharinha segurava na mão do Polidoro que segurava na mão do Gaudêncio. Quim tomava conta do pacote de balas. Lázaro Salém veio correndo do balcão e obrigou a família a entrar. Seu Dagoberto queria um paletó de alpaca. A mulher queria um corte de cassa verde ou (...)Vivia passando a língua nos lábios. Comprara o último retrato de Buck Jones. E alimentava uma paixão exaltada pelo turco da Rua Brigadeiro Tobias $\mathrm{n}^{\circ}$ 24-D sobrado. Só porque o turco usava costeletas. Um perigo em suma". 4

No fragmento acima, não há qualquer menção à palavra judeu ou qualquer referência que remeta ao judaísmo. Um leitor com um menor repertório e conhecimento sobre imigração e/ou sobre a comunidade judaica, não irá supor que o sobrenome Salém do atendente da loja, tradicionalmente árabe, pode também ser de um judeu sefardita, "que deriva da expressão hebraica Shalom". 5

E o que pode significar a palavra turco inserida no segundo fragmento do texto?

Com auxílio de outros elementos históricos e sociais podemos supor que Lázaro Salém seja um dos muitos judeus sefarditas que moravam e trabalhavam no Bom Retiro, local onde o conto é ambientado. Já a expressão "turco" para designar o morador do $n^{\circ}$ 24-D da Rua Brigadeiro Tobias, em São Paulo - Capital, pode ser, sim, uma alcunha para judeu.

\footnotetext{
${ }^{4}$ MACHADO, António de Alcântara. Novelas Paulistanas. Rio de Janeiro, Ediouro, 1999.

${ }^{5}$ FAUSTO, Boris. Negócios e Ócios. histórias da imigração. São Paulo, Cia das Letras, 1997.
} 
Mas como chegar a uma conclusão? Em primeiro lugar, a citação do local oferece uma pista: a rua Brigadeiro Tobias, nas cercanias da Estação da Luz, próximo ao Bom Retiro, bairro paulistano conhecido por abrigar muitos judeus que aportaram no Brasil desde o final do século XIX.

Os primeiros imigrantes judeus que chegaram aqui por volta de 1900 eram sefarditas, oriundos do antigo Império Turco-Otomano, conhecidos na comunidade como turquinos, e pela população em geral como turcos. Por muito tempo, estes mesmos imigrantes judeus ficaram conhecidos pela alcunha de "turco da prestação", não só por conta do país de origem, mas também pela profissão, pois muitos vendiam roupas e armarinhos pelo sistema de prestação e de porta em porta. ${ }^{6}$ Não que todos fossem realmente turcos, muitos vieram do Líbano, Marrocos, Palestina e outras localidades que, na época, faziam parte do Império Turco-Otomano. Porém o passaporte era turco.

Mesmo após a chegada de muitos imigrantes judeus ashkenazitas, provenientes da Europa Central, Oriental e do Norte, portanto distantes da região da Turquia, a população local continuou a identificar os judeus como turcos, situação esta que ainda persiste em algumas localidades, especialmente no nordeste brasileiro.

Retomando o trecho do conto, se nos detivermos nas características do autor, teremos ainda que Alcântara Machado era um escritor voltado para as crônicas, retratando sempre o imigrante, o operário urbano, enfim a vida da cidade de São Paulo no início do século XX com todos seus migrantes, não só estrangeiros, mas também do próprio país.

Quando o autor cita "um perigo em suma", o que quer ele dizer? O fragmento retirado é curto, não é possível inferir nenhuma consideração mais detalhada, mas quando é feita a leitura do conto percebe-se que a matriarca Silvana preocupava-se com a filha Nharinha, enamorada pelo vizinho. O tal perigo podia ser a adolescência da menina que aflorava ou o fato de o turco querer se aproveitar da ingenuidade da moça que vinha do interior ou, ainda, pode ser que o elemento estrangeiro causasse um certo temor, e o autor encontrou esta forma para expressá-lo.

\footnotetext{
${ }^{6}$ Ver Jeffrey Lesser em $O$ judeu é o turco da prestação: etnicidade, assimilação e imagens das elites sobre árabes e judeus no Brasil. Estudos Afro-Aiáticos (Rio de Janeiro), v27, abril, 1995.
} 
Mas isto só poderá ser confirmado através de um estudo mais aprofundado, pesquisando o que o autor lia, o que escrevia quando trabalhava em jornais, quais pensadores influenciaram seu escritos, entre outros aspectos.

Esta dissertação de mestrado iria, inicialmente, focar os anos compreendidos entre 1900 e 1945, período que se mostrou um tanto longo e com uma produção literária muito rica e numerosa. Estes fatos mostraram a necessidade de redução do recorte temporal, a pesquisa sendo restringida, então, ao período entre 1920 e 1940, os anos mais férteis e quando os judeus começam a ter visibilidade social e, conseqüentemente, literária.

Através de um levantamento das obras e seus respectivos autores e uma abordagem do contexto histórico-sócio-cultural, este projeto tem como objetivo principal identificar o personagem judeu na literatura brasileira: como foi retratado, as características que lhe foram atribuídas e sua importância e papel no texto literário. Mas esta identificação não visa simplesmente destacá-lo como o único elemento "diferente" nesta sociedade em formação, mas sim identificá-lo e mostrar a forma de tratamento recebida, comparativamente com os demais elementos estrangeiros que compunham a sociedade brasileira naqueles tempos.

Esta pesquisa vem acrescentar mais elementos aos estudos já existentes que abordam o tema, no intuito de mostrar como o judeu é representado na literatura brasileira, pois como já foi dito anteriormente, a literatura funciona como um espelho que reflete a sociedade onde está inserida. Através da ficção, teremos uma indicação de um momento histórico, em uma abordagem diferenciada do enfoque apresentado pelos historiadores, podendo constituir uma pesquisa de referência para futuros estudos que abordem o judeu na literatura e/ou na sociedade brasileira nos primórdios do século XX.

Além disto, a oportunidade que tive ao fazer este trabalho transcende os limites acadêmicos, pois é um encontro com reminiscências de meu passado. Ao iniciar os estudos na área de Língua, Literatura e Cultura Judaicas, deparei com elementos que me eram muito familiares. Algo próximo do expressado por Maurice Lamm, ao falar dos marranos brasileiros. 
"Muitos dos marranos, ao batismo, observavam os rituais cristãos apenas externamente. No íntimo de suas almas, eles continuaram observando os costumes judaicos. Curiosamente, a escolha das observâncias era quase aleatória e exclusiva de cada comunidade. Por exemplo, as velas de Shabat eram acesas no porão, de modo clandestino e seguro, enquanto outras cerimônias importantes foram descartadas, mesmo na privacidade. Por séculos, seus descendentes continuaram a praticar sub-repticiamente estes costumes e leis, como era o costume de sua família, embora eles não soubessem mais porque assim o procediam." 7

Quando encontrei este texto de Lamm, lembrei-me de minha mãe acendendo suas velas, no fundo de nossa casa na Vila Pompéia e sempre às sextas-feiras. Lá não se comia carne de porco e ainda tinhamos o hábito de cobrir os espelhos quando falecia algum parente.

Tais costumes pareciam estranhos aos olhos de nossos vizinhos e até mesmo para alguns membros mais distantates da família, mas estavam presentes em nosso cotidiano, em nossa memória. Tanto minha mãe, quanto minha avó e demais membros da família. não compreendiam o que isto representava e qual seu significado. Apenas recentemente, quando iniciei os estudos, é que consegui decifrar estes enigmas que me rodeavam e estão em minha família há muitas gerações.

\footnotetext{
${ }^{7}$ Lamm, Maurice. Bem vindo ao judaísmo: retorno e conversão. Tradução Dagoberto Mensch. São Paulo, Sêfer, 1999. Pág. 426, 427.
} 


\section{6 - OBJETIVO DA PESQUISA}

Conforme já foi antecipado pela "Introdução", o objetivo principal desta pesquisa é identificar o personagem judeu na literatura brasileira: como foi retratado, as características que lhe foram atribuídas e sua importância e papel no texto literário. Mas esta identificação não visa simplesmente destacá-lo como o único elemento "diferente" nesta sociedade em formação, mas sim identificá-lo e mostrar a forma de tratamento recebida, comparativamente com os demais elementos estrangeiros que compunham a sociedade brasileira naqueles tempos.

Não se trata, porém, de um simples levantamento de obras. Foi também estabelecido que seria detalhado o estudo de um dos autores do período, tendo sido escolhida a obra do autor Gilberto de Mello Freyre.

Tal escolha se deu, sobretudo, em virtude do ineditismo e da forma particular com que aborda os judeus e a cultura judaica, elementos que, em geral, se fazem presentes no conjunto de sua obra, especialmente naquelas escritas dentro do período a ser estudado. Tudo isto, aliado à possibilidade de mensurar a importância dos judeus dentro deste contexto de colonização e formação do povo brasileiro a partir do olhar de um autor reconhecido internacionalmente e ao fato de que os estudos sobre sua obra transitam por várias áreas, como sociologia, antropologia, história e até mesmo pela literatura. 


\section{7 - METODOLOGIA DE PESQUISA}

No início de um estudo como este, deve ser apresentada uma metodologia de pesquisa, para tornar claro o caminho a ser percorrido e que, ao final, se consiga atingir seu objetivo, pois caso contrário poderá o pesquisador andar em círculos.

Para iniciar esta pesquisa, também foi elaborada uma metodologia, conforme segue:

\subsection{Delimitação do período:}

Como já foi mencionado na "Introdução", o período a ser pesquisado seria, inicialmente, de 45 anos, entre 1900 e 1945 (portanto, do início do século $X X$ até o final da $2^{\mathrm{a}}$ Grande Guerra, para se fechar um ciclo histórico), mas por ser muito extenso e por conta do grande número de obras produzidas neste intervalo, foi necessário reduzi-lo em alguns anos. Assim, o período foi delimitado entre 1920 e 1940, que cobre o pré-Modernismo e o próprio Modernismo.

Cabe salientar que as obras pesquisadas entre 1900 e 1919, bem como as pesquisadas entre 1941 e 1945, embora não façam mais parte do projeto e, portanto, não tenham sido estudadas, constarão da relação de obras. Tal medida visa preservar a pesquisa inicial que foi efetivamente realizada e auxiliar estudos e pesquisas futuras sobre o mesmo assunto.

\subsection{Escolha dos autores e das obras que serão estudadas:}

As obras foram selecionadas através de dois critérios. Primeiro, é que tenham sido produzidas dentro do período delimitado e o segundo, que tenham sido escritas por autores brasileiros.

Em seguida, foram catalogadas todas as obras que seriam estudadas, separadas por ano de publicação. Esta relação servirá de guia para todo o trabalho, desde as pesquisas em biblioteca até a conclusão. Com ela, será possível mensurar se todo o período foi pesquisado e as obras, lidas. Ver anexo II. 


\subsection{Análise do texto:}

Todos os livros pesquisados, que compõem a maior parte das obras escritas no período (não estando esgotado o universo total de livros), serão lidos, fichados e colocadas as indicações da existência de personagens judeus e/ou estrangeiros, referências à cultura judaica e/ou estrangeiras e outros elementos auxiliares na compreensão e análise da obra e que sejam elucidativos à pesquisa. A ficha utilizada encontra-se no Anexo I.

Devido ao grande número de autores, seria quase impossível analisar pormenorizadamente cada um deles. Assim, foi estabelecido que seria detalhado apenas o estudo sobre a obra do autor Gilberto Freyre. Tal escolha se deu, sobretudo, em virtude da forma particular com que aborda os judeus e a cultura judaica, elementos que sempre se fazem presentes no conjunto de sua obra, especialmente naquelas escritas dentro do período a ser estudado.

Para avaliar como Gilberto Freyre retratou os judeus, foi feita uma comparação entre a forma de abordargem utilizada pelo autor para retratar não apenas o judeu, mas o estrangeiro em geral e os negros, além de ser elaborada uma análise em que foram levantados os seguintes pontos:

- notícias sobre o autor e sua obra;

- definição do universo da obra (lugar, época da ação, tempo de duração, personagens, estilo, características principais);

- ação principal;

- identificação dos personagens judeus (se são principais e/ou secundários, importância, objetivos, vontade, consciência, determinações);

- conflitos enfrentados pelos personagens judeus;

- modo de caracterização dos personagens judeus (pensamento, ações etc...);

- funções dos personagens judeus. 


\subsection{Conclusão:}

Após todo o levantamento, as obras serão situadas no contexto histórico e social para, finalmente, ser desenvolvida uma conclusão sobre aquilo que foi pesquisado. 


\section{8 - SÍNTESE DA PRESENÇA JUDAICA NO BRASIL}

Para a melhor compreensão do momento histórico da pesquisa é necessário que se faça, primeiramente, um apanhado da presença judaica no Brasil nos últimos quinhentos anos.

Em 12 de outubro de 1492, no mesmo dia em que Colombo chegou às Américas, os Reis da Espanha deram um ultimato aos judeus, expulsando-os daquele país. Muitos emigraram para Portugal, Norte da África, Holanda e para o extinto Império Turco-Otomano, onde hoje se localiza a maior parte dos países da região do Oriente Médio.

O Brasil foi oficialmente descoberto em 22 de abril de 1500, fato ocorrido depois de um período de grandes expedições marítimas em que Portugal e Espanha se destacaram com primazia.

A história do povo judeu no Brasil é feita de altos e baixos, mas de forma única, pois em nenhum outro país se pode dizer que os judeus tenham vivido ao longo de toda a sua existência contribuindo substancialmente para o seu desenvolvimento econômico e social, apesar das perseguições e dos tentáculos da Inquisição que aqui se fizeram presentes.

De fato, desde o descobrimento do país - evento do qual os judeus também participaram, tendo inclusive ajudado em seus preparativos (como cartógrafos, cosmógrafos, astrônomos, matemáticos e outras atividades científicas da época), até os dias atuais, quase sem intermitência, aberta ou disfarçadamente, estiveram integrados no processo de formação da nacionalidade brasileira.

Assim, o infante D. Henrique, que tinha a alcunha de "O Navegador", ao fundar, no ano de 1412, a primeira academia de navegação, a famosa "Escola de Sagres", escolheu para sua direção um dos mais famosos cartógrafos daquele século, o judeu Jehuda Crescas, indo buscá-lo nas Ilhas Baleares (pequeno arquipélago 
espanhol do Mediterrâneo Ocidental, formado por 4 ilhas: Maiorca, Minorca, Ibiza e Formentera).

Jehuda Crescas, conhecido como "mestre Jácome de Maiorca" e, devido a sua grande experiência na fabricação de bússolas, também chamado de "El judio de las Brújulas", teve por essencial missão ensinar aos portugueses os fundamentos da navegação e a produção e manejo de cartas e instrumentos náuticos.

Apenas como exemplo, há casos de judeus de renome científico que prestaram sua colaboração à Escola de Sagres, destacando-se entre eles José Vizinho, mestre Rodrigo e, sobretudo, Abraham Zacuto. Este último, autor do Almanaque Perpétuo de todos os Movimentos Celestes, indivíduo de grande influência em todas as decisões que diziam respeito aos interesses do Estado Português, inclusive sobre às expedições oceânicas, uma das quais, a importante e bem sucedida viagem de Vasco da Gama que o levou ao caminho marítimo das Índias, foi por ele planejada. ${ }^{8}$

Vale salientar que, embora os judeus tenham representado continuamente uma parcela da sociedade, a sua história não acompanha simplesmente a do Brasil. Longe de um esperado paralelismo, o que se verifica é a existência de inúmeros desvios e meandros, os quais não raro atingem um grau de contraste.

Um bom exemplo é o período da invasão holandesa. Considerado como um fracasso para o país, constituiu-se, entretanto, no ponto mais alto do desenvolvimento da coletividade judaica local, dando-se o inverso com a fase subseqüente, quando, após a expulsão dos invasores, sobreveio a decomposição, o êxodo e a dispersão dos judeus no Brasil.

O mesmo ocorreu durante as intensas perseguições religiosas ocorridas na primeira metade do século XVIII, de parcos efeitos diretos sobre a população geral do país, mas que tiveram influência marcante sobre a vida dos judeus brasileiros, cujas famílias fugiram da Europa em virtude dessas mesmas perseguições. ${ }^{9}$

Finalmente, sob outro aspecto, a implantação do regime e disposições liberais no país, no início do século XIX, culminando com a proclamação da Independência, e

\footnotetext{
${ }^{8}$ Sobre o navegador Gaspar da Gama há um obra dedicada exclusivamente a ele, elaborada por Elias Lipiner, intitulada Gaspar da Gama: um converso na frota de Cabral. Rio de Janeiro, Nova Fronteira, 1987.
} 
que resultou tão favoravelmente ao progresso geral do país. Este novo cenário, porém, determinou a assimilação quase total dos judeus, efeito este que é tido como negativo do ponto de vista da preservação de uma identidade judaica e de uma comunidade judaica brasileira.

Mas o período de maior tranqüilidade e crescimento da população judaica no Brasil foi, sem dúvida, o da invasão holandesa. Após uma série de tentativas frustradas com que visavam reconquistar a região da Bahia no decorrer do ano de 1627 , os holandeses verificaram que a façanha seria mais facilmente executada em Pernambuco. Região com pior defesa e mais fácil de ser fortificada posteriormente, atacaram-na em 15 de fevereiro de 1630 com uma poderosa esquadra composta de setenta navios, guarnecida e tripulada por aproximadamente sete mil homens, iniciando assim a ocupação do Nordeste brasileiro, a qual iria durar até o ano de 1654, centralizada na próspera capitania de Pernambuco.

Este período é singular na vida judaica no Brasil, sendo considerado como totalmente relacionado com a ocupação holandesa, com ela tendo iniciado e se encerrado quase que abruptamente.

O que mais impressiona, no entanto, não é essa coincidência, mas a rapidez com que os judeus ocuparam o Nordeste brasileiro, uma comunidade das mais florescentes do mundo de então.

De fato, não se deve levar em conta a tumultuada fase de 1630 a 1635, em que se processou a consolidação da conquista e que foi assinalada por incessantes combates, devido à resistência tenaz dos pernambucanos. Do mesmo modo, se deve deduzir a fase de decadência do domínio holandês, que se estendeu de 1645 a 1654. Resta, assim, o período de 1635 a 1644, que abrangeu o governo liberal e progressista do Conde Maurício de Nassau, espaço esse de pouco mais de 10 anos, o qual, entretanto, bastou aos judeus para alcançarem um nível excepcional na vida econômica, social e cultural.

A ocupação holandesa do Nordeste brasileiro introduziu modificações na vida econômica dos judeus, alargando seus horizontes. Eles diversificaram e

\footnotetext{
${ }^{9}$ Com relação ao período marcado pelas perseguições ver a obra Cristãos Novos na Bahia: a inquisicão, elaborada por Anita Novinsky e publicada pela Editora Perspectiva, São Paulo, 1970.
} 
desenvolveram novas atividades, incrementando e aumentando gradativamente suas potencialidades.

Antes da conquista holandesa, os judeus exerciam, em larga escala, as atividades de plantadores de açúcar, mas os donos de engenho representavam apenas uma percentagem razoável, e os bem sucedidos não passavam de uma escassa minoria. No mais, a colônia judaica era constituída de pequenos comerciantes e de profissionais artesanais, muito mal remunerados.

Com a chegada dos holandeses e a decorrente implantação de uma grande liberdade religiosa, o panorama foi se alterando. Levas ininterruptas de judeus aportavam em Pernambuco, oriundos de vários países, especialmente da Holanda, que era a metrópole, trazendo riquezas, experiência comercial e um prodigioso espírito de realização.

Estes judeus vindos da Holanda, que em grande parte eram ex-refugiados de Portugal, Espanha e França, tinham a vantagem de falar vários idiomas: espanhol, francês, ladino e holandês, além do mais importante, "o português", a língua falada no Brasil (ao menos pelos colonizadores). Era fácil, então, servir de intérpretes para os 7.000 homens do exército e da marinha holandesa, constituídos de mercenários de várias nacionalidades, muitos sendo holandeses, outros ingleses, franceses, alemães e até poloneses, que não falavam ou entendiam a língua portuguesa. ${ }^{10}$

De meros intérpretes, foram paulatinamente mudando suas tarefas e logo passaram à prática do escambo, desenvolvendo-se, mais tarde, no comércio. Exerceram também a tarefa de intermediários, que se tornou quase monopólio dos judeus, com os quais não podiam competir os pequenos negociantes e operários brasileiros e flamengos.

Por volta de 1638, aproveitando-se do confisco dos engenhos de cana-de-açúcar pertencentes aos portugueses, feito pelos governantes holandeses, que puseram essas propriedades em licitação pública, os judeus os arremataram e fizeram grandes aquisições por preços considerados irrisórios.

\footnotetext{
${ }^{10}$ No livro A História do Povo de Israel, Abba Eban dedica um capítulo inteiro sobre a expulsão dos judeus na Espanha e em Portugal, como chegaram a Holanda e no "novo mundo".
} 
Não tardou assim que os judeus se tornassem grandes proprietários urbanos e rurais, controlando a vida econômica da "Nova Holanda". Vale lembrar, como testemunho do período, que a principal rua de Recife naquela época era conhecida como "Rua dos Judeus" (após 1654, foi renomeada pelos novos administradores para "Rua da Cruz" e, posteriormente, como "Rua do Bom Jesus", nome que permanece até os dias atuais) e o porto da cidade era popularmente conhecido como "O Cais dos Judeus".

A prosperidade do povo judeu nas terras da "Nova Holanda" não passou totalmente sem incômodos. O crescimento do seu bem-estar e o desenvolvimento extraordinário do seu poderio econômico despertaram a inveja da concorrência e geraram uma perigosa inimizade com a comunidade cristã.

Se tais ondas de xenofobia não tiveram maiores conseqüências, o fato se deve à ação equilibrada no governo de Maurício de Nassau, que, durante uma administração que durou apenas sete anos, trabalhou para estabelecer a união de todas as correntes religiosas na colônia, distribuindo justiça imparcial: era o primeiro a exigir reparação quando ocorriam provadas infrações cometidas por judeus, mas também sabia defendê-los quando os via vítimas da inveja e do atiçamento dos concorrentes que usavam a religião como desculpa para descontar o fracasso nos negócios. ${ }^{11}$

Sob o domínio holandês, a população judaica pôde crescer e se solidificar, concentrando-se em Recife, bastando dizer que, enquanto essa cidade, em 1630, apenas possuía 150 casas, já em 1639 ali passaram a existir 2.000 construções residenciais. Havia judeus em tamanho número que, à primeira vista, se tinha a impressão de uma cidade puramente judaica.

Esse crescimento populacional dos judeus no Brasil resultou principalmente da intensa imigração que se operou naquele período. Vieram judeus de diversos países, sobretudo da Holanda. Do porto de Amsterdã, partiam continuamente embarcações carregadas de judeus e conversos, sendo que só de uma feita, em 1642, embarcaram número próximo de 600 emigrantes.

\footnotetext{
${ }^{11}$ O livro Os Holandeses no Brasil, escrito em 1955 por Varnhage, traça um bom panorama sobre o período holandês (ver bibliografia).
} 
Não se sabe exatamente o número de judeus que viviam no Brasil holandês. A maioria dos historiadores cita a elevada cifra de 5.000 pessoas. Ainda que esse número seja um tanto excessivo (parece mais aceitável a quantia de 1.500 indivíduos), o certo é que, no auge do desenvolvimento da comunidade judaica da Nova Holanda, os judeus representavam cerca de $50 \%$ de toda a população civil, na época estimada em 3.000 pessoas.

Para se ter uma idéia da importância deste dado, no tempo em que Pernambuco se constituía em uma comunidade israelita com mais ou menos 1.500 pessoas, basta lembrar que a própria comunidade judaica de Amsterdã, no seu apogeu, não era muito mais numerosa que isto.

Em virtude das condições favoráveis existentes e que foram citadas, é perfeitamente compreensível que a vida social dos judeus em Pernambuco evoluísse rapidamente até assumir a forma de uma sociedade organizada.

A esta altura, já existiam duas sinagogas - uma no Recife, a outra na localidade de Santo Antônio - e um cemitério próprio na Boa Vista. Possuíam os judeus pernambucanos uma comunidade sagrada, a "kahal kadoch".

Havia ainda uma Congregação, a "Sur Israel do Recife", que mantinha um "Pinkes" (livro de atas) e baixava "hascamot" (regulamentos). Assim, os regulamentos revistos em 1648 estabeleciam que todos os judeus residentes no Estado do Brasil e todos os futuros imigrantes tornavam-se automaticamente membros da Comunidade Judaica e deviam inscrever seus nomes no Pinkes como demonstração de que aceitavam os regulamentos.

Também na ilha de Itamaracá (litoral de Pernambuco), formou-se uma comunidade presidida por um rabino próprio, Jacob Lagarto, que foi o primeiro escritor talmúdico na América do Sul. Em tal ambiente de segurança e de organização coletiva, a consciência de grupo se sobressaiu, chegando as festas judaicas a serem celebradas publicamente.

O auge desse desenvolvimento sócio-cultural, de fundo predominantemente religioso, foi atingido pelos judeus em Pernambuco por volta de 1642, quando 
providenciaram a vinda da Holanda de um destacado líder espiritual, Isaac Aboab da Fonseca, que veio acompanhado do hazan Moisés Rafael de Aguiar.

Isaac Aboab era nascido em Portugal, de onde emigrou para a Holanda, contando então com sete anos de idade. Em Amsterdã, desenvolveu seus dotes e, em virtude de suas qualidades excepcionais, fez brilhante carreira, alcançando altas posições, inclusive a de membro do rabinato. ${ }^{12}$

Quando se pensou em enviar um rabino para o Brasil, foi ele o escolhido pelo presidente da comunidade holandesa, o que, aliás, serve para corroborar a importância que então se atribuía à coletividade israelita que existia no Nordeste brasileiro, além do fato de Isaac Aboab possuir o domínio das línguas portuguesa e holandesa.

Quando o rabino Aboab chegou ao Brasil, já encontrou uma vida judaica completamente desenvolvida, um local ideal para aplicar sua experiência e seus conhecimentos. Desdobrou-se em várias atividades, com destaque para seus admiráveis discursos sobre leis e costumes judaicos, cujo êxito era devido não só aos seus vastos conhecimentos, mas também à sua extraordinária arte de falar bem e pelo fato de discursar em português.

Paralelamente às atividades rabínicas, Isaac Aboab continuou no Brasil seus trabalhos literários, tendo escrito, em colaboração com o rabino Moisés Rafael de Aguiar, a obra Miimei lehuda, que trata da vida cultural dos judeus brasileiros. Permaneceu Isaac Aboab à frente da comunidade brasileira até o final, quando os portugueses retomaram Pernambuco e expulsaram os holandeses do Brasil, em 1654

Por volta do ano de 1645, a vida judaica no Brasil entra em estágio de estagnação e começa a declinar. A bem dizer, isto já vinha acontecendo desde 6 de maio de 1644, data em que Nassau, após uma série de desentendimentos com a Companhia das Índias Ocidentais, deixa o governo, marcando o fim simbólico dessa fase que iria terminar uma década mais tarde com a liqüidação da comunidade que havia sido implantada, aparentemente com tanta solidez, na região Nordeste do Brasil.

\footnotetext{
${ }^{12}$ Sobre o rabino Isaac Aboab da Fonseca há um importante texto: Isaac Aboab, “The First Jewish Author in America”, escrito por M. Kayserling e inserido na obra American Jewish Historical Society (ver bibliografia).
} 
Sobre a atitude do judeus de assumirem inteira fidelidade aos holandeses remanescentes de Recife, não faltam pronunciamentos desfavoráveis, sendo descrita por historiadores como uma espécie de deslealdade ou ingratidão para com Portugal e com o Brasil.

Vale lembrar que o Brasil, como uma colônia portuguesa, não estava propriamente em jogo. Aos membros da comunidade judaica impunha-se escolher entre dois senhores, entre duas potências estrangeiras daquele tempo, Portugal e Holanda, ambas querendo o domínio dos mares e ansiando mais colônias e fontes de riquezas para o abastecimento de suas metrópoles.

De um lado, estava o país que perseguia seu povo, torturava, expulsava e o queimava vivo; do outro, a nação que agia para com os judeus, tanto na metrópole como nas colônias, com a maior tolerância religiosa possível. Ou seja, de um lado, a Inquisição e seus autos de fé; do outro, a liberdade de consciência e expressão.

Entre as duas opções, não havia outra possibilidade de escolha. Agindo como agiram, os judeus mantiveram uma coerência. Eles ajudaram os holandeses a conquistar o nordeste brasileiro, na esperança, de obterem no Brasil um lar tranqüilo, como haviam sido Espanha e Portugal num passado até então recente. Não poderiam virar as costas ou abandonar os aliados e protetores da véspera no momento em que a sorte era substituída por um grande revés.

Assim como souberam usufruir dos benefícios de viver na Nova Holanda, os judeus também mostraram saber suportar a sua ruína, lutando bravamente até a derradeira queda de sua cidade, com o que se haveria de encerrar o ciclo mais glorioso, embora curto, da vida judaica no Brasil colônia.

Não obstante o acordo feito entre os holandeses com os portugueses no sentido de ficarem impunes os judeus remanescentes ou permitir a estes emigrar em busca de um refúgio onde pudessem reconstruir as suas vidas, uma pequena parcela resignou-se a permanecer no Brasil, dispersando-se pelo seu território, enquanto o grosso optou pela emigração. 
Destes, um grupo, constituído provavelmente dos mais afortunados e bem relacionados na Holanda, entre eles o próprio chefe da comunidade, o rabino Isaac Aboab da Fonseca, decidiu retornar a esse país, ao passo que a maioria, a parte menos abonada da comunidade, preferiu enfrentar o desconhecido, aventurando-se em direção das mais longínquas paragens nas três Américas. ${ }^{13}$

Os que regressaram à Holanda se reintegraram na comunidade judaica, sem que deixassem maiores vestígios; os outros foram pulverizados entre diversas colônias francesas, inglesas e holandesas das Américas.

O fim do período holandês marca o início da inquisição portuguesa no Brasil. A acomodação, tão bem levada a efeito pelos judeus brasileiros na segunda metade do século XVII, não chegou ao século seguinte, quando, afinal, a Inquisição de Lisboa, cujas garras até então mal haviam conseguido arranhar a população judaica do Brasil, acabou estendendo sobre este país as suas implacáveis perseguições.

Essa onda de terror que, com algumas intermitências, se desdobrou por longos setenta anos, com especial virulência nos períodos compreendidos entre 1707 a 1711 e 1729 a 1739, e conferiu à primeira metade do século XVIII as características de época negra para a história dos judeus no Brasil.

A perseguição aos cristãos-novos em Portugal atingira então justamente o seu apogeu, assumindo a face cruel da Inquisição, em aspectos verdadeiramente pavorosos. Despovoavam-se extensas zonas de Portugal e a Europa contemplava atônita uma nação que se destruía à ordem de religiosos. Não admira, pois, que tal fúria acabasse também repercutindo em suas colônias.

Por outro lado, os judeus aqui residentes, graças ao seu ajustamento econômico e social, operado na segunda metade do século XVII, haviam voltado a constituir uma parcela das mais opulentas da colônia; havia, pois, bens a serem confiscados, e com facilidade.

E, se isso não bastasse, foi designado o bispo do Rio de Janeiro, D. Francisco de São Jerônimo, que exercera, em Évora, o cargo de qualificador do Santo Ofício, ali se distinguindo pela sua intolerância religiosa e pelo seu rancor contra os judeus.

\footnotetext{
${ }^{13}$ Ver matéria publicada pela jornalista Dina Duarte Rota de Passagem: Historiadores restauram sinagoga dos judeus recifenses que ajundaram a fundar Nova YorK, in Revista Veja 07/04/1999. São Paulo, Abril, 1999.
} 
Tão furiosa passou a ser então a caça aos judeus brasileiros, principalmente na região do Rio de Janeiro e região da Paraíba, que, apenas entre 1707 e 1711, levou mais de 500 pessoas prisioneiras para a Inquisição de Lisboa. Um número considerável para a época, mesmo porque a população da colônia naqueles tempos era muita pequena.

O pânico se alastrou, paralisando por completo o desenvolvimento das relações mercantis da colônia com a metrópole, e a esta causando tão sérios prejuízos que a coroa portuguesa afinal se viu forçada a proibir que prosseguisse o confisco dos engenhos de açúcar, na maioria pertencentes a indivíduos de origem judaica.

Sucedeu então uma relativa calmaria, que, entretanto, não chegou a durar mais do que vinte anos, tendo neste intervalo os judeus se refeito dos abalos anteriores e mesmo voltado a enriquecer graças ao incremento da exploração das minas de ouro e do comércio de diamantes. Mas logo recomeçou a sanha dos inquisidores, atraídos pelas renascidas perspectivas de maciços confiscos.

A nova fase de perseguições, mais intensa durante o decênio 1729-1739, prosseguiu, praticamente, até 1770 , quando outras condições vieram aniquilar para sempre a inquisição, que tanto manchara a história de Portugal e fizera também decair o grande império construído nos tempos manoelinos.

Até hoje não se sabe ao certo quantos judeus residentes no Brasil caíram vítimas da Inquisição de Portugal. Há quem estime em quase dois mil o número dos “judaizantes" brasileiros processados.

Estas cifras parecem ser relativamente modestas para os 230 anos de funcionamento da inquisição em Portugal, mas tal estimativa parece longe de dar uma idéia exata da extensão que na verdade a tragédia assumiu. Há ainda hoje, nos arquivos da Torre do Tombo, em Lisboa, 40 mil processos de Inquisição, sendo que a maioria permanece intacta, cujos mistérios aguardam o trabalho paciente de estudiosos que se disponham a desvendá-los para revelar à história todos estes fatos.

Entre as vítimas brasileiras, uma das mais ilustres é Antônio José da Silva, conhecido pela alcunha de "O Judeu". Nascido no Rio de Janeiro, em 1705, quando tinha apenas oito anos de idade foi obrigado a mudar-se junto com seu pai 
para Lisboa, aonde acabava de ser enviada como prisioneira sua mãe, acusada de “judaizar" pelos agentes da Inquisição.

Em Portugal, Antônio José da Silva freqüentou o colégio e a universidade, sempre revelando excepcionais dotes de inteligência e invulgar tendências literárias. Em poucos anos, seu espírito criador enriqueceu a literatura portuguesa de numerosas peças teatrais de singular valor, atingindo os mais altos degraus da fama e da popularidade.

Como em suas peças teatrais, extravasasse, com freqüência, seu sarcasmo contra a atividade da Inquisição, esta o marcou e não mais descansou enquanto não conseguiu interromper suas atividades. Tentaram a princípio intimidá-lo, confiscando-Ihe os bens e "esmagando-lhe os dedos" - ato este praticado na igreja de São Domingos em 13 de outubro de 1726, no intuito de que assim não mais viesse a escrever.

Constando que, com isso, haviam acirrado ainda mais o seu ódio contra o tribunal, os inquisidores enredaram Antônio José da Silva numa complicada trama de denúncias e falsos testemunhos, entre os quais o de que ele ria do nome de Cristo, jejuava às segundas e quintas-feiras, vestia roupa limpa aos sábados e rezava o Padre Nosso substituindo, no fim, o nome de Jesus pelo de Abraão.

Condenado à pena de morte em 11 de março de 1739, foi queimado em 21 de outubro do mesmo ano, em praça pública, não faltando ao suplício requintes de crueldade: foram obrigadas a assistir ao ato sua mãe, que contava então com mais de setenta anos, sua mulher e sua filha de quatro anos. Tudo praticado em nome de Deus, da Igreja e do Santo Ofício. Esta é apenas uma das histórias conhecidas. O que não estará guardado nos já citados quarenta mil processos que estão fechados na Torre do Tombo em Portugal?

Por volta de 1770, iniciou-se um novo ciclo para a vida judaica no Brasil, sem nenhuma semelhança com todo o seu passado. As cinco décadas seguintes constituiram uma fase de transição para uma política liberal, que não mais sofreria retrocessos, ampliando cada vez mais suas conquistas até a eclosão definitiva em 1824, após a proclamação da independência do Brasil e sua constitucionalização. 
Em Portugal, o cenário mudara e a Inquisição entrara em declínio em virtude da ação do ministro Sebastião José de Carvalho e Melo, mais conhecido como o Marquês de Pombal, homem de grande visão e ideais libertários.

Em 5 de outubro de 1768, como medida inovadora, o Marquês de Pombal desarticulou os defensores da Inquisição, dando um prazo de quatro meses àqueles que tivessem filhos em idade de casamento para que procedessem união matrimonial com famílias de cristãos-novos, até então excluídas.

Poucos anos depois, na data de 25 de maio de 1773, foi conseguido junto ao rei de Portugal, D. José I, a promulgação de uma lei que extinguiu as diferenças entre cristãos-velhos e cristãos-novos.

Tal lei revogou todos os decretos e disposições com respeito à discriminação contra os cristãos-novos. As penalidades pela simples aplicação da palavra "cristão-novo" a quem quer que fosse, por escrito ou oralmente, eram rigorosas, e seus infratores punidos com chicoteamento em praça pública ou até corriam o risco de serem degredados para a Colônia de Angola.

O Brasil, após a promulgação de sua primeira constituição, assistia à implantação de uma inovadora liberdade de consciência. Da população judaica, não restava quase nada, pois já estava bastante reduzida como conseqüência da assimilação ao longo dos últimos dois séculos.

Os judeus remanescentes no Brasil, cujo espírito coletivo estava debilitado, pois quase só se consideravam judeus em virtude da discriminação vinda de fora, logo perceberam que, desta vez, a liberdade viera em caráter definitivo, tendo sido rompidos os últimos elos de fundo discriminatório que os prendiam ao passado judaico.

O único fator que, nessa conjuntura criada após a Constituição de 1824, talvez ainda lograsse reacender a chama passada e preservar aqueles judeus da assimilação total, teria sido uma imigração maciça e homogênea de judeus, de nível elevado e de tradições afins.

Depois da Independência, o movimento de imigração no Brasil enfraqueceu muito. A imigração judaica praticamente não existiu nesse período. Evidentemente, não se 
pode levar em conta os judeus esporadicamente encontrados no meio de grupos de imigrantes europeus.

Tais elementos isolados, oriundos provavelmente de comunidades já bastante assimiladas da Europa ocidental, passaram a atuar no país de forma exclusivamente individual, sem a menor manifestação de tradições e hábitos judaicos. Cabe, apenas, abrir parênteses para uma exceção ocorrida no extremo norte do país.

Logo após a Independência do Brasil (1822), começaram a chegar para a região da Amazônia (mais precisamente para os atuais estados do Pará e Amazonas), pequenos grupos de imigrantes judeus provenientes do Marrocos, principalmente de Tanger e Tetuan.

Tratando-se de uma imigração de origem nova, sem qualquer afinidade histórica ou cultural com a população brasileira da região, e dado o clima liberal criado pela Constituição de 1824, ficará mais fácil e cômodo a esses judeus marroquinos conservarem sua religião e tradições, vindo a fundar, em 1828, uma sinagoga de nome "Shaar ha Shamayim" ("Porta do Céu"), na cidade de Belém do Pará.

O estatuto da liberdade religiosa, assinado em 1810, beneficiou muito os judeus. Em 1812, o primeiro grupo de sefarditas radicou-se na Amazônia. Em 1850, judeus de todas as procedências espalharam-se pelo Brasil, mas em pequena quantidade e sem organização, não constituindo uma corrente migratória.

Com o passar dos anos, a comunidade judaica da Amazônia, ampliada de maneira contínua com elementos oriundos do norte da África, difundiu-se pelos pontos estratégicos do grande rio, passando a desempenhar um papel relevante no desenvolvimento econômico da região, bem como no intercâmbio comercial com o estrangeiro.

Entretanto, essa pequena comunidade judaica da Amazônia, pouco numerosa, estava isolada cultural e materialmente das regiões vitais e mais adiantadas do país. Por esta razão, a existência dessa comunidade não tira do período compreendido entre 1824-1855 a sua característica inconfundível, que é a de se ter processado a profunda assimilação da população judaica remanescente após a Independência do Brasil. 
Esta migração para a região amazônica acentuou-se em conseqüência do ciclo da borracha iniciado em fins do século XIX. Os lucros auferidos com a extração e venda da borracha atraíram muitos migrantes, inclusive israelitas. Em 1890, a região atinge o seu auge, em virtude da recém-criada indústria automobilística americana.

A situação alterou-se depois de 1912, quando a produção estagnou-se, pois o Brasil não era mais o único produtor de borracha no mundo. As pequenas vilas e cidades minguaram e a maior parte da população se mudou para Manaus e Belém. $O$ mesmo ocorreu com a população judaica que primeiramente concentrou-se nas capitais (Belém e Manaus) e, posteriormente, dirigiu-se para o Centro-Sul do país.

O certo é que não há notícias de ondas migratórias de judeus para o Brasil nos séculos XVII e XVIII. No século seguinte, surgem pequenos núcleos comunitários na região norte, como já citado, e na segunda metade do século XIX, os primeiros judeus ashkenazitas começam a aportar no litoral brasileiro, em cidades como Salvador, Recife, Rio de Janeiro e Santos.

No início do século $X X$, os Estados Unidos da América restringem a entrada de minorias com a "Quota Act". Assim, muitos emigrantes judeus acabam escolhendo o Brasil como residência devido às dificuldades que enfrentavam no continente Europeu, onde, além dos problemas causados pela $1^{\text {a }}$ Guerra Mundial, eram hostilizados em alguns países. Esse fluxo acentuou-se na década de 20.

Segundo o autor Jeffrey Lesser: "A imigração judaica tornou-se foco de atenção entre os intelectuais brasileiros e membros do governo nas décadas de 20 e 30.(...) Os imigrantes vindos do Leste europeu não apenas expandiram a população judaica do Brasil, de aproximadamente quinze mil, em 1920, para cerca de cinco vezes esse número apenas duas décadas mais tarde, mas muitos imigrantes e refugiados judeus também galgaram com sucesso os degraus da ascensão econômica nas cidades brasileiras. (...) Para os judeus (e muitos outros imigrantes), o Brasil era o país do futuro; mas para muitos brasileiros influentes, os judeus eram imaginados como sendo o menos desejável de todos os grupos de imigrantes." 14

\footnotetext{
${ }^{14}$ LESSER, Jeffrey. O Brasil e a questão judaica: imigração, diplomacia e preconceito. Tradução Marisa Sanematsu. Rio de Janeiro, Imago, 1995. Pág. 29
} 
Há registros de que, a partir de 1933 indo até 1942, chegaram ao Brasil aproximadamente 25 mil judeus, em sua maioria provenientes da Europa CentroOriental. Apesar das proibições impostas pelo governo federal a partir de 1935, que simplesmente negavam vistos a imigrantes judeus, o fluxo de imigrantes de origem judaica manteve-se até a entrada do Brasil na $2^{\mathrm{a}}$ Guerra Mundial. Houve inclusive, por parte do Governo Federal, a emissão de circulares secretas que proibiam a entrada de imigrantes semitas.

"Os judeus foram enquadrados nos estereótipos dos inassimiláveis, tornando-se inadequados ao projeto de construção da brasilidade. Os argumentos utilizados foram vários. Ora por serem portadores de uma religião não passível de amálgama, vale dizer, por serem inconvertíveis; ora por serem usurários e, portanto, desprovidos de consciência solidária; ora por serem parasitas sociais, vivendo do comércio que os transformava em usurpadores do trabalhador e do povo brasileiro; ora por estarem ligados à exploração do lenocínio, uma chaga social, ora por serem comunistas subversivos, transformado-se em ameaça ao poder constituído; ora por serem parte do capitalismo internacional e, portanto , materialistas e gananciosos; ora por serem apátridas transformavam-se em agentes a serviço de qualquer país e responsáveis pela disseminação de ideologias estrangeiras. Em suma, indesejáveis em todos os sentidos porque rotulados como opositores do progresso e do engrandecimento da pátria brasileira. O integralismo reforçou ainda mais o perfil negativo do judeu, com base na tese de regeneração nacional, exibindo motivação ideológica para forçar a limitação dos contigentes indesejados, estabelecendo-se, dessa forma, uma diferenciação entre europeus legitimados e não-legitimados como sujeitos do processo imigratório." 15

E isto ocorreu em uma época nada tranqüila, pois o Brasil passava por um período ditatorial conhecido como "Estado Novo", além de flertar com o regime nazista da Alemanha, que gerou por aqui um movimento assemelhado num arremedo do nazismo e conhecido pelo nome de "Integralismo".

\footnotetext{
${ }^{15}$ WALDMAN, Berta. Entre passos e rastros: presença judaica na literatura brasileira contemporânea. São Paulo, Perspectiva, 2003. Pág. XVII (Introdução)
} 
A aproximação da $2^{\mathrm{a}}$ Guerra Mundial e a crescente aproximação americana do Brasil gerou também um conseqüente afastamento do Brasil e Alemanha, o que causou um certo alívio para a comunidade judaica brasileira, que, após o Estado Novo, andava muito preocupada devido a uma série de medidas que escancaravam o anti-semitismo do governo Vargas, de seus partidários e dos intelectuais do novo governo.

"O caráter do regime imposto por Vargas apresentava algumas analogias com os regimes autoritários existentes na Europa de então, principalmente o da Itália de Mussolini. Entretanto, dificilmente poderíamos distinguir as restrições impostas aos judeus daquelas impostas pelo governo norte-americano de Franklin Roosevelt, ou pelo governo britânico, no mesmo momento. “ 16

Um pouco antes do início da Segunda Guerra Mundial, um incidente provocou grande mal estar aos brasileiros e, sobretudo, aos judeus que aqui haviam se refugiados. Getúlio Vargas, então presidente da República, enviou a esposa de Luiz Carlos Prestes, seu adversário político, para a Gestapo. Olga Benário era judia, estava grávida e deu à luz num campo de concentração. Sua filha sobreviveu, mas Olga não teve a mesma sorte. ${ }^{17}$

Apenas com a entrada do país na $2^{a}$ Guerra ao lado dos Aliados é que houve um certo alívio para a comunidade judaica brasileira. "Com o Brasil como membro das forças aliadas, muito do antagonismo direcionado contra os refugiados judeus pareceu diminuir. Essa mudança estava certamente relacionada a uma diminuição da propaganda nazista na imprensa brasileira" 18

A mudança de posição do Brasil no início dos conflitos da Segunda Guerra Mundial gerou também a renúncia de alguns dos mais importantes propagadores da ideologia nazista no país, entre eles Felinto Müller, que chefiava a polícia política de Vargas, além do Ministro da Justiça e o Chefe do Departamento de Imprensa e Propaganda (DIP), órgão responsável pela divulgação do ideário nazista e da propaganda anti-semita que circulava pela imprensa.

\footnotetext{
${ }^{16}$ GRÜN, Roberto. Construindo um lugar ao sol: os judeus no Brasil. In Fazer a América: a imigração em massa para a América Latina. Org. Bóris Fausto. São Paulo, EDUSP, 1999. Pág. 374.

${ }^{17}$ Um estudo aprofundado sobre o assunto foi feito pelo escritor Fernando Morais em seu livro Olga.
} 
Vale salientar que o anti-semitismo no Brasil se fazia presente, principalmente, dentro dos órgãos governamentais e entre os intelectuais do sistema, que, através de seus quadros, defendiam e difundiam os ideais de pensadores como Theodor Fritsch, Conde Arthur de Gobineau, Max Stiner, Chamberlain, entre outros. ${ }^{19}$

Mais tarde, entre 1946 e 1958, outra leva de judeus desembarcaria no Brasil, muitos sobreviventes da Segunda Guerra e outros provenientes do Egito, em virtude da expulsão promovida por Nasser, totalizando algo próximo de 36 mil pessoas.

"Poucos conflitos dentro do governo brasileiro provocaram tanta paixão ou atraíram tanta atenção quanto a imigração judaica durante 1939. Mais de quatro mil judeus entraram no Brasil naquele ano, o maior número registrado desde 1929. Esse aumento significativo não deve sugerir o desaparecimento dos preconceitos contra os judeus em geral e os imigrantes e refugiados judeus em particular. De fato, as imagens tradicionais acerca dos judeus - como estando interessados em se estabelecer nas áreas urbanas, jamais na terra; como voltados para as finanças e poderosos em âmbito internacional - , que haviam dado suporte para tanto ódio contra eles, eram, no final de 1938 e início de 1939, vistas cada vez mais como indicadores de sua utilidade para o desenvolvimento econômico do Brasil. Em outras palavras, os estereótipos sobre os judeus, que anteriormente haviam sido considerados negativos, começaram a ser vistos como atributos positivos por alguns políticos federais influentes." 20

A reação internacional à política brasileira de imigração, o maior comprometimento dos Estados Unidos da América com a questão dos refugiados, entre outros fatores, proporcionou uma chance de sobrevivência a aproximadamente 10 mil judeus que conseguiram abrigo em solo brasileiro, entre os anos de 1939 e 1945.

No Brasil, moderno/contemporâneo, o fato de um indivíduo ser judeu não era, em nenhum momento, um empecilho para seu crescimento pessoal, profissional e econômico. Mesmo quando tratamos da questão da segurança, aqui não houve

${ }^{18}$ LESSER, Jeffrey. O Brasil e a questão judaica: imigração, diplomacia e preconceito. Tradução Marisa Sanematsu. Rio de Janeiro, Imago, 1995. Pág. 250.

${ }^{19}$ Hanna Arendt comenta estes pensadores em O Sistema Totalitário. 
nenhum ataque deliberado à comunidade judaica, diferentemente do que ocorreu em países como a Argentina e na Europa Oriental e Central, além é claro da Alemanha, Austria, Holanda, Bélgica e Itália.

Segundo Roberto Grün, o fato de alguém ser judeu não era um elemento negativo e sim positivo, sendo isto uma qualidade: "é necessário constatar que, no Brasil, ser judeu é um trunfo. Aqui, além de simplesmente satisfazer os desejos familiares, a identificação do indivíduo como judeu também fornece boas expectativas de inserção no mercado de trabalho qualificado, nas redes empresariais e mesmo nas redes de relações sociais." 21

Tudo que foi exposto neste capítulo mostra quão longa é a presença judaica no Brasil, com altos e baixos, com períodos de repressão e liberdade. Presença que ficou ausente dos livros de história por um longo período e que começou a ser resgatada apenas no início do século passado, quando estudiosos como Sergio Buarque de Hollanda e Gilberto Freyre foram em busca das orígens do povo brasileiro, elaborando estudos e levantamentos, descolados do pensamento homogeneizador da elite cultural do país.

Este pequeno relato da presença judaica no Brasil serve para situar o leitor e esclarecer episódios que marcaram significativamente alguns períodos da história do Brasil, especialmente a era Vargas, quando a questão da imigração assume um novo papel, os movimentos nacionalistas tomam vigor e a questão judaica passa a ser discutida mundialmente, fatos que passam a fazer parte da literatura e refletem o momento levantado nesta pesquisa.

\footnotetext{
${ }^{20}$ LESSER, Jeffrey. O Brasil e a questão judaica: imigração, diplomacia e preconceito. Tradução Marisa Sanematsu. Rio de Janeiro, Imago, 1995. Pág. 217.

${ }^{21}$ GRÜN, Roberto. Construindo um lugar ao sol: os judeus no Brasil. In Fazer a América: a imigração em massa para a América Latina. Org. Bóris Fausto. São Paulo, EDUSP, 1999. Pág. 368.
} 


\subsection{OS REFLEXOS NA LITERATURA}

A chegada do século $X X$ foi muito importante para a literatura brasileira, sobretudo os anos compreendidos entre 1920 e 1940, período fértil por conta de grandes transformações sociais, econômicas e culturais, além das duas grandes guerras, que deixaram cicatrizes profundas em todo o mundo.

Ainda no século XIX, o Brasil trocou a monarquia pela república, a escravidão pelo trabalho remunerado e empreendeu mudanças significativas em todas as áreas. $\mathrm{O}$ trabalho passou a ser assalariado, a agricultura aos poucos perdeu espaço para a indústria e a população paulatinamente se transferiu para as cidades.

Assim se inicia o século $X X$, quando os brasileiros assistiram à chegada de grandes levas de imigrantes europeus, ao surgimento de metrópoles como São Paulo e Rio de Janeiro, além da urbanização e industrialização de muitas outras cidades, bem como o aparecimento de uma classe média ávida por adquirir novos conhecimentos e cultura.

Outro fator que merece atenção no período é a problemática do analfabetismo. O Brasil era essencialmente um país de analfabetos, uma vez que, durante séculos, a educação havia sido restrita à elite.

Após 1759, com a expulsão dos jesuítas pelo Marquês de Pombal, ocorreu a primeira reforma do ensino que perdurou sem muitas alterações até a chegada da Família Real, em 1808. Foi D. João VI quem criou as primeiras academias, a militar e a da marinha. Também é de sua autoria o surgimento do ensino de medicina e cirurgia.

Em 1890, o Brasil ainda possuía uma maioria absoluta de analfabetos aproximadamente $84 \%$ da população. Em 1920, houve uma ligeira redução, passando para $75 \%$ da população e em 1940 , final do período estudado, ainda havia uma cifra de analfabetos que correspondia a $57 \%$ da população. 
O brasileiro era formado por um contigente essencialmente pobre, constituído de negros recém-libertos (a abolição da escravatura era muito recente, ocorrera em 1888), muitos imigrantes europeus e japoneses em busca de melhores condições de vida. Em síntese, uma população que vivia essencialmente da agricultura e afastada dos livros e bancos escolares e que, portanto, não dominava a língua portuguesa.

A literatura era feita pela elite e para a elite, pois a maior parte dos brasileiros não tinha condições de compreender o que estava escrito nos livros e tampouco dispunha de condições financeiras para adquirir um, pois os parcos rendimentos serviam, sobretudo, para manter a sobrevivência.

É possível afirmar que, no princípio da colonização brasileira, não havia uma produção literária local, mas sim importada de Portugal ou da França, lembrando que mesmo em Portugal a elite já importava literatura e obras técnicas e/ou científicas da França.

Talvez a literatura seja a área que tenha sofrido maior influência da cultura francesa, pois os movimentos literários brasileiros foram praticamente originários ou inspirados em movimentos semelhantes que surgiram na França.

Essas influências se acentuam ainda mais com a mudança da família real portuguesa para o Brasil, em 1808, trazendo consigo o espírito do Movimento Romântico europeu.

Os escritores brasileiros começaram a enfatizar a liberdade individual, o subjetivismo e uma até então inédita preocupação por assuntos sociais. Logo após a proclamação da independência brasileira, a literatura romântica se expandiu para exaltar a singularidade das regiões tropicais do Brasil e de seus índios, os escravos africanos e descrições da vida urbana.

Nessa época, a imprensa brasileira assimilou da França a idéia da publicação seriada de romances em jornais, forma essa iniciada pelos periódicos franceses $\mathrm{La}$ Presse e Le Siècle. Manuel Antônio de Almeida (1831-1861), creditado como iniciador da literatura picaresca no Brasil com Memórias de um Sargento de Milícias, e José de Alencar, autor de O Guarani, publicaram primeiramente esses romances em jornal, sob a forma de romance em folhetim. 
No Brasil, o desenvolvimento do folhetim se deu quase que simultaneamente a seu surgimento na França. Com intervalo de tempo relativamente curto, o Jornal do Comércio, Correio Mercantil, Diário do Rio de Janeiro e outros jornais brasileiros trazem ao nosso público os grandes folhetins franceses, tais como Os Mistérios de Paris, O Conde de Monte Cristo e O Judeu Errante, este último popularizando entre nós o prenome oriental "Djalma".

O gênero folhetim entrou em declínio no final do século XIX. Com o avançar dos anos e apesar do desenvolvimento da imprensa no século $X X$, o gênero foi sendo deixado de lado. Embora alijado paulatinamente do jornal onde nasceu, o folhetim ganhou, ao longo do século XX, novos espaços. No Brasil, foi para o rádio, atingindo seu auge em forma de radionovelas (décadas de 40 e 50) e, posteriormente, na televisão ressurgiu como telenovela, desde os anos 50 até os dias atuais.

Durante o período compreendido entre a época colonial e a primeira metade do século XX, a porção letrada do país era muito pequena, os pobres muito raramente aprendiam a ler e a escrever, assim a literatura era feita pela rara burguesia e lida por ela mesma. Os mais letrados admiravam os grandes pensadores franceses. Os ideais franceses de liberdade, igualdade e fraternidade eram invejados no país dos golpes de estado e ditaduras.

As grandes transformações sociais que o país sofreu, a industrialização, o surgimento de uma pequena classe média, o enriquecimento das cidades e a expansão do ensino propiciaram uma grande mudança no cenário nacional.

Nas primeiras décadas do século XX, há um grande incremento nas artes em geral, o que explicaria em parte a "Semana de 22". O surgimento de uma pequena burguesia ávida por conhecimento direcionou os rumos das artes e da cultura. A literatura na época era a forma mais popular de expressão cultural e, neste período, a produção literária cresce vertiginosamente, bem como o número de leitores.

Isto pode ser confirmado na própria pesquisa aqui apresentada. Conforme avançamos nos anos, podemos perceber que aumenta significativamente o número de autores e obras, isto sem falar nas novas edições de antigos romances. O próprio formato das obras também sofre alterações. 
Nos primeiros anos do século $\mathrm{XX}$, as obras eram compostas, em sua maioria, de poemas e com um número reduzido de páginas; com o passar dos anos, este formato vai sendo gradativamente alterado, o número de páginas aumenta e a poesia cede espaço à prosa e, pouco a pouco, a cultura francesa, que tanto influenciara os brasileiros até aquele momento, perde força e abre espaço para a cultura brasileira, que começa a receber maior respeito por parte dos intelectuais.

O período que está em estudo coincide com o início do Modernismo no Brasil e que constitui um momento singular na história da literatura nacional. Enquanto São Paulo e Rio de Janeiro exalam os novos ares da modernidade, na região Nordeste o destaque é um movimento ao mesmo tempo similar e antagônico, o Regionalismo.

O Modernismo brasileiro pretendia romper os laços com o passado, com 0 academicismo e com a escola francesa do Parnasianismo. Em contraste, a Escola de Recife (o epicentro do movimento nordestino), encabeçada por Gilberto Freyre, assume um processo de renovação cultural diverso do que se desenvolvia no eixo Rio-São Paulo.

O Regionalismo se apresentava similar ao Modernismo porque também rompia os laços com o academicismo e os muitos movimentos culturais que imitavam a Europa (especialmente a França), mas, ao mesmo tempo, assumia uma identidade própria e divergente, menos homogeneizadora.

Enquanto Mario e Oswald de Andrade lideravam o Modernismo em São Paulo e estavam identificados com a vanguarda na Europa, Gilberto Freyre seguiu por outros caminhos, buscando outros valores, que preteriam os estrangeirismos e valorizavam os hábitos e tradições regionais, que deram ao movimento por este liderado com uma aparência dissonante e que acabou por distingui-lo dos modernistas paulistas e cariocas.

O discurso moderno e simultaneamente conservador de Gilberto Freyre em suas três principais obras (Manifesto Regionalista, Casa Grande \& Senzala e Sobrados e Mucambos), é o que mais chama a atenção no período, tanto por impactar os discursos políticos e acadêmicos, como também pelo fato de desacreditar a verdade assentada no discurso de Oliveira Vianna sobre a formação e evolução do povo 
brasileiro, que reconstituiu a história social de uma sociedade heterogênea e falsamente harmônica.

Esta diferenciação é muito importante para que se possa compreender melhor o Modernismo como um fenômeno cultural e a obra de Gilberto Freyre daquele período, muito voltada para as questões sociais e resgate das tradições do Nordeste brasileiro, conforme veremos mais à frente.

"Gilberto Freyre começou a publicar os seus ensaios nos anos 20, e só na década seguinte é que foram publicados os seus livros mais importantes - Casa Grande \& Senzala, Sobrados e Mucambos e Nordeste -, na ocasião em que, na procura de uma identidade, discutia-se muito o problema racial." 22

Vale salientar que no final dos anos 20 e início da década de 30, havia no Brasil uma grande corrente de escritores conservadores que apregoavam as idéias de raça e de nacionalismo, entre eles Oliveira Viana, Menotti del Picchia, Graça Aranha, Afonso Arinos de Mello Franco, Gustavo Barroso, Miguel Reale e outros. Alguns eram destacados membros da sociedade e faziam parte tanto do cenário literário, como da política nacional, agindo como os intelectuais da era Vargas.

"A imprensa integralista divulgou amplamente a campanha anti-semita de Gustavo Barroso, que distorcia os fatos, transformando-os em grandes peças de ficção. Barroso atacou o deputado Horácio Lafer e outros empresários judeus em $A$ Sinagoga Paulista e apenas raramente era responsabilizado por suas mentiras." 23

Da mesma forma que Gustavo Barroso (um admirador declarado do nazismo e de seu líder), muitos autores utilizavam a literatura para disseminar os ideais do nazismo: de raça, de anti-semitismo; seja escrevendo suas próprias obras ou traduzindo livros estrangeiros como Os Protocolos dos Sábios do Sião, O Judeu Internacional etc.

Segundo afirma Roberto Grün em Construindo um lugar ao sol: judeus no Brasil, o anti-semitismo de Gustavo Barroso era mais um produto simbólico que ideológico, utilizado tanto para ganhar espaço dentro do movimento integralista, como no

${ }^{22}$ ANDRADE, Manoel Correia de. O espaço geográfico na obra de Gilberto Freyre. In Gilberto Freyre em quatro tempos. Bauru, Edusc, 2003. Pág. 225. 
cenário político do período. Tal afirmação é baseada no fato de Barroso ter sido um intelectual muito renomado nas décadas de 40 e 50 e este não fazer qualquer menção sobre seu anti-semitismo após o término da Segunda Grande Guerra.

"Assim, vemos que tensões da Europa repercutiram ponderavelmente aqui. Não mais como transposição, mas como manifestação de uma solidariedade cultural intensificada depois da Primeira Guerra Mundial e do nosso progresso econômico. Direita e esquerda política refletindo na literatura; populismo literário e problemas psicológicos; socialismo e neotomismo; surrealismo e neo-realismo; laicismo e arregimentação católica; libertação de costumes, formação de opinião política; eis alguns traços marcados e freqüentemente contraditórios do decênio de 30, assinalando, quer a projeção estética e ideológica do Modernismo, quer a reação do espiritualismo literário e ideológico." 24

Desta forma, o que vemos é um período muito rico e cheio de novos ideais, que foram transportados para a literatura. Uma literatura que muito refletiu aquele momento histórico/político. Gilberto Freyre, um dos mais festejados escritores do período, é sem dúvida uma boa fonte de pesquisa, onde se encontra muito do que foi falado sobre a presença judaica no país e sobre a literatura, havendo uma fusão de literatura, história, sociologia, o olhar sobre o imigrante e o que mais interessa para esta dissertação, a questão judaica.

\footnotetext{
${ }^{23}$ LESSER, Jeffrey. O Brasil e a questão judaica: imigração, diplomacia e preconceito. Tradução Marisa Sanematsu. Rio de Janeiro, Imago, 1995. Pág. 113.

${ }^{24}$ CÂNDIDO, Antonio. Literatura e Sociedade. São Paulo, Cia. Editora Nacioanl, 1976. Pág. 125, 126.
} 


\section{9 - OS JUDEUS EM GILBERTO FREYRE}

"O Gilberto Freyre que desejo lembrar no momento de sua morte é o que vai de 1933, publicação de Casa Grande \& Senzala, até 1945, quando foi eleito pela Esquerda Democrática deputado à Assembléia Nacional Constituinte. Esse foi o Gilberto da nossa mocidade, cujo grande livro sacudiu uma geração inteira, provocando nela um deslumbramento como deve ter havido poucos na história mental do Brasil”

Antonio Cândido

(trecho de artigo publicado em $O$ Estado de São Paulo, logo ao saber da morte de Gilberto Freyre, em 1987)

Um dos objetivos deste estudo é mensurar a importância dos judeus dentro deste contexto de colonização e formação do povo brasileiro, a partir do olhar de Gilberto Freyre.

Em primeiro lugar, podemos inferir que Freyre foi um dos primeiros autores brasileiros, senão o primeiro, a reconhecer a importância e o papel da comunidade judaica, tanto na formação do povo português, quanto na colonização e formação da população brasileira e no legado judaico que permanece nos hábitos e costumes do Brasil.

Além disto, não podemos deixar de mencionar a importância de Gilberto Freyre na sociologia, antropologia, história e também na moderna literatura brasileira. A originalidade de sua obra ajudou a renovar os estudos sobre o Brasil e o povo brasileiro, revendo o papel do negro, das populações rurais, da imigração em geral e do contato de diferentes culturas que aqui se encontraram.

Porém, não podemos destacar apenas os pontos positivos de sua obra, sendo necessário apontar a dualidade existente em seus textos e as contradições 
suscitadas, a mistura que às vezes ocorre entre raça e cultura, a aproximação e o afastamento que faz em relação ao antropólogo Franz Boas, alemão, de origem judia, que vivia na América e de quem foi discípulo na conceituada Universidade de Columbia.

Suas posições políticas, em particular sua aproximação com o salazarismo (apesar de ter sido eleito, em 1946, deputado federal pela UDN, partido de centro-esquerda), contribuíram e interferiram nas leituras feitas de sua obra.

Seus críticos não lhe pouparam hostilidades que dificultaram a análise e reconhecimento de seu trabalho. Outra questão importante neste estudo é identificar se havia ou não, na obra de Freyre, um discurso anti-semita.

Um exemplo é o que ocorreu na Idade Moderna, onde a Igreja Católica e o Absolutismo Português sustentaram uma situação racista acobertada por argumentos religiosos e justificativas de inquietudes com o bem-estar do povo. Assim, o marrano ou cristão-novo se tornou, na boca do povo e através de documentos oficiais, o responsável pela maior parte das mazelas que afligiam os países ibéricos e suas colônias, entre elas o Brasil.

Tal situação se perpetuava por conta do interesse da aristocracia em dificultar e impedir o enfraquecimento dos partidários do antigo regime e brecar o avanço e a participação de parte da burguesia comercial (especialmente de origem judaica) junto às esferas de poder.

Muito deste ideário foi perpetuado através dos séculos e permaneceu no discurso da classe dominante. Gilberto Freyre era um dos filhos desta classe, nascido em uma família com posses, e teve oportunidades ímpares, como por exemplo a possibilidade de terminar sua formação acadêmica nos Estados Unidos da América. Assim, o que se pergunta é se Freyre pode ter reproduzido em sua obra um discurso que atravessou séculos de história. "Por isso, os dominados aparecem nos textos dos historiadores sempre a partir do modo como eram vistos e compreendidos pelos próprios vencedores". 25

\footnotetext{
${ }^{25}$ CHAUI, Marilena de Souza. O que é ideologia. São Paulo, Brasiliense, 1984 - pág. 124.
} 


\subsection{QUEM FOI GILBERTO FREYRE?}

Para se compreender melhor a obra de um autor, primeiro deve-se saber quem é ele, o que fez, pois em geral seu trabalho irá refletir, ao menos em certa medida, um pouco de sua vida. Assim a pergunta que intitula esta parte do estudo torma-se muito importante para uma melhor compreensão de Freyre, pernambucano nascido na cidade de Recife, a 25 de março do ano de 1900. Filho de Alfredo Freyre e de Francisca de Mello Freyre, ambos membros de famílias renomadas de Pernambuco.

Criado no seio de uma família tradicional e pertencente à oligarquia regional, Gilberto Freyre estudou em um colégio Batista em Recife e, aos 17 anos, seguiu para os Estados Unidos para concluir seus estudos, bacharelando-se em Artes Liberais, com especialização em Ciências Políticas e Sociais, pela Universidade de Baylor.

Aproveitando a estadia fora, após concluir sua graduação, rumou para a Universidade de Colúmbia e lá cursou a pós-graduação, quando trabalhou com o tema Vida social no Brasil em meados do século $X I X^{26}$ e que posteriormente viria a ser retomado e desenvolvido, tornando-se a obra que lhe deu maior prestígio, Casa Grande \& Senzala.

Vivendo em Pernambuco por quase toda sua vida, refletiu o amor à terra natal no conjunto de sua obra, sempre retratando o nordeste, seu povo e sua gente. Merecem destaque os guias práticos que publicou sobre Recife e Olinda, onde pôde mostrar um pouco da vida e do povo pernambucano nos idos das décadas de 20 e 30.

"O Recife foi o primeiro ponto da América do Sul em que tocou o Zeppelin, na viagem que iniciou a linha de comunicação regular da Alemanha com o Brasil. Viagem que trouxe ao Recife uma elegante figura de príncipe e de sportsman - o Infante Dom Alfonso, de Espanha. O infante visitou no Recife vários pontos, a 
começar pelo Departamento de Saúde, que achou admirável. Mas a impressão mais forte que levou foi a do Haras Maranguape (Paulista), dos Lundgren: pernambucanos descendentes de pai sueco e de mãe alemã." 27

Mesmo quando trata dos judeus no Recife, faz uma ponte entre o passado e presente, situando o leitor sobre o que encontrará na cidade: "Hoje o Recife tem duas sinagogas e um número considerável de judeus: mas não de sefardins. Judeus arruivados, vindos da Rússia e da Polônia na maior parte. Os sefardins, depois da reconquista portuguêsa, foram quase todos embora.(...) Os israelitas - vindos da Europa Central, principalmente, e não mais sefardins, como outrora - recomeçam a ser numerosos no Recife (...)." 28

A última citação reflete bem o período, pois Recife realmente abrigou uma considerável comunidade judaica na primeira metade do século XX. Apenas para ilustrar melhor, podemos lembrar de Clarice Lispector que, ainda menina, foi com sua família morar no Recife, em 1924.

"Como a família Lispector contava com parentes no Brasil, a carta de chamada viabilizou a imigração, consumada com sua chegada a Maceió, capital de Alagoas, possivelmente em fevereiro de 1921. De Alagoas a família segue para o Recife, em 1924(...)" 29

Se formos mais a fundo na vida da escritora Clarice Lispector, que é uma figura notória do grande público, teremos mais provas de como Recife possuía uma comunidade judaica presente e visível aos olhos de quem lá estivesse. "Consta que seu pai lia jornais nessa língua, e ela própria freqüentou a escola israelita no Recife - o Colégio Hebreu Ídiche Brasileiro - , onde teria aprendido o hebraico e o ídiche, trajetória comum aos filhos dos imigrantes judeus no Brasil." 30

\footnotetext{
${ }^{26}$ Esta tese posteriormente virou livro, tendo sido publicado em 1964 pelo Instituto Joaquim nabuco de Pesquisas Sociais, com título homônimo.

${ }^{27}$ FREYRE, Gilberto. Guia Prético, Histórico e Sentimental da cidade do Recife. $4{ }^{\text {a }}$ Edição. Rio de Janeiro, José Olympio 1968. pág. 148

${ }^{28}$ FREYRE, Gilberto. Guia Prético, Histórico e Sentimental da cidade do Recife. $4{ }^{\text {a }}$ Edição. Rio de Janeiro, José Olympio 1968. pág. 141

29 WALDMAN, Berta. Entre passos e rastros: presença judaica na literatura brasileira contemporânea. São Paulo, Perspectiva, 2003. Pág. 17
} 
Assim, o que se percebe é que Freyre não só conviveu com muitos judeus no E.U.A., como também em Pernambuco, onde ainda hoje existem rastros da presença judaica no Brasil colonial, além, é claro, da forte presença dos imigrantes judeus ashkenazitas que lá aportaram nos primórdios do século passado. O que por si só não prova que isto o influenciou nos seus escritos, mas deixa uma pista de onde teria advindo o conhecimento que sempre demonstrou possuir sobre os judeus, sua cultura e religião.

Gilberto Freyre possui uma história pessoal muito singular. Nasceu em uma família pernambucana, ainda jovem aproximou-se do protestantismo e estudou em um colégio batista. Enquanto seus pares concluíam seus estudos na Europa e bebiam na fonte da modernidade, Freyre preferiu uma universidade norte-americana, tendo se formado em Ciências Sociais, com direcionamento para a área de antropologia, em Baylor, uma universidade agregada da Igreja Batista, localizada na cidade de Waco, no estado do Texas.

Após o fim de sua graduação, Gilberto Freyre, influenciado pelo embaixador brasileiro em Washington, Oliveira Lima, transfere-se para a Universidade de Colúmbia, onde fez seu curso de mestrado.

Em Colúmbia, foi discípulo do conceituado Franz Boas, um judeu alemão radicado nos Estados Unidos. "Boas estava no auge de sua carreira como antropólogo, como o mais importante acadêmico a se opor ao racismo científico nos E.U.A. Seus alunos teriam um enorme peso ao levar a mensagem anti-racista à comunidade acadêmica norte-americana. Freyre a trouxe para o Brasil". 31

No prefácio da $1^{\mathrm{a}}$ edição de Casa Grande \& Senzala, o próprio Freyre comenta a influência que sofreu de Franz Boas: : "O Professor Franz Boas é a figura de mestre de que me ficou até hoje maior impressão." 32

Ainda referindo-se ao mestre que o orientou na antropologia, Freyre afirma categoricamente que Casa Grande \& Senzala foi escrita com base nas influências de Boas: "Foi o estudo de Antropologia sob a orientação do Professor Boas que

\footnotetext{
${ }^{30}$ WALDMAN, Berta. Entre passos e rastros: presença judaica na literatura brasileira contemporânea. São Paulo, Perspectiva, 2003. Pág. XXV (Introdução)

${ }^{31}$ SKIDMORE, Thomas. in Gilberto Freyre em quatro tempos/organização Ethel Volfzon Kominsky, Claude Lépine, Fernanda Arêas Peixoto. Bauru, EDUSC, 2003. Pág. 48
} 
primeiro me revelou o negro e o mulato no seu justo valor - separados dos traços de raça, dos efeitos do ambiente ou da experiência cultural. Aprendi a considerar fundamental a diferença entre raça e cultura; a discriminar entre os efeitos de relações puramente genéticas e os de influências sociais, de herança cultural e de meio. Neste critério de diferenciação fundamental entre raça e cultura assenta todo o plano deste ensaio." 33

Durante o período em que Freyre esteve ausente do Brasil, o cenário artístico e literário passou por grandes transformações. Quando do seu retorno em 1923, já havia ocorrido a Semana de Arte Moderna de 1922, que mudaria significativamente os rumos da literatura brasileira.

No nordeste, mais tardiamente (segunda metade da década de 20), também se iniciava um movimento modernista, o Regionalismo, embora muitos dos contemporâneos de Freyre discordem sobre o exato papel desempenhado por ele neste cenário. O certo é que sua presença pode ser sentida no Manifesto Regionalista, de 1926, sendo esta talvez uma das obras mais significativas e conhecidas do Movimento. O Regionalismo inicia uma releitura do passado brasileiro, que pode ser muito bem traduzida por Freyre no Manifesto Regionalista, onde procura explicar o que é o Movimento, qual suas finalidades e afinidades, bem como tenta explicar o presente através de uma nova leitura do passado.

Ao retornar ao Recife em 1923, após uma jornada de estudos que durou aproximadamente cinco anos, Freyre estava intelectualmente mais maduro, lastreado por uma formação diferenciada, especialmente na área sociológica.

“E, através do jornal e da ação pessoal, desde o seu regresso do estrangeiro, não só se empenharia em difundir entre nós alguns dos modernos escritores da América do Norte e da Europa, particularmente da Inglaterra, como reagiria violentamente contra o proverbial descaso do brasileiro pela conservação de suas tradições, pelo conhecimento aprofundado delas, sempre seduzidos que fomos pelas

\footnotetext{
${ }^{32}$ FREYRE, Gilberto. Casa Grande \& Senzala. 34 ed. Rio de Janeiro, Record. 1992. Pag. XLVII.

${ }^{33}$ FREYRE, Gilberto. Casa Grande \& Senzala. 34 ${ }^{\mathrm{a}}$ ed. Rio de Janeiro, Record. 1992. Pag. XLVII e XLVIII.
} 
modernizações de superfície, não raro alimentadas por inexplicável complexo de inferioridade." 34

${ }^{34}$ CASTELLO, José Aderaldo. José Lins do Rêgo: Modernismo e Regionalismo. São Paulo, EDART, 1961. Pág. 32 e 33. 


\subsection{A OBRA DE GILBERTO FREYRE}

Vale salientar que não será estudada toda a obra de Gilberto Freyre, mas somente os trabalhos mais representativos e que se encontram dentro do período delimitado por esta pesquisa, ou seja, de 1920 a 1940. São eles:

- Manifesto Regionalista (1926);

- Casa Grande \& Senzala (1933);

- Guia Prático, Histórico e Sentimental da Cidade do Recife (1934);

- Retalhos de Jornais Velhos (1935);

- Sobrados e Mucambos (1936);

- Nordeste (1937);

- Mucambos do Nordeste (1937);

- Conferências na Europa (1938);

- Açúcar (1939);

- Olinda - $2^{\circ}$ Guia Prático, Histórico e Sentimental de Cidade Brasileira (1939);

- Um Engenheiro Francês no Brasil (1940);

- Memórias de um Cavalcanti (1940);

- O Mundo que o Português Criou (1940). 


\subsection{MANIFESTO REGIONALISTA - 1926}

Escrito em 1926 para o $1^{\circ}$ Congresso Brasileiro de Regionalismo, ocorrido no Recife, Pernambuco, foi publicado, neste mesmo ano, em forma de artigos em jornal (Diário de Pernambuco), e só tomou o formato de livro em 1952. O Manifesto é um importante registro do Regionalismo, onde Freyre coloca à mesa a tradição brasileira e o cadinho cultural de nossas origens, tentando romper com a crescente assimilação de culturas estrangeiras que se processava no Brasil.

Freyre inicia o texto expondo o grupo: quem eram seus membros, suas reuniões, o local onde se reuniam e qual sua finalidade: "Toda terça-feira, um grupo apolítico de regionalistas vem se reunindo na casa do Professor Odilon Nestor, em volta da mesa de chá com sequilhos tradicionais da região - inclusive sorvete de Coração da Índia - preparados por mãos de sinhás. Discutem-se então, em voz mais de conversa que de discurso, problemas do Nordeste. (...) Seu fim não é desenvolver a mística de que, no Brasil, só o Nordeste tenha valor. (...) Os animadores desta nova espécie de Regionalismo desejam ver se desenvolverem no País outros regionalismos que se juntem ao do Nordeste, dando ao movimentoo sentido organicamente brasileiro, e até, americano, quando não mais amplo, que ele deve ter." 35

Mais adiante, Freyre dá ênfase à releitura do passado, buscando uma saída diferente para o país, onde a cultura brasileira possa se sobressair rompendo com o colonialismo cultural que tanto influenciava e incomodava o autor: "(...) o caminho indicado pelo bom senso para a reorganização nacional parece ser o de dar-se, antes de tudo, atenção ao corpo do Brasil, vítima, desde que é nação, das estrangeirices que the têm sido impostas, sem nenhum respeito pelas peculiaridades e desigualdades da sua configuração física e social; e com uma outra pena de índio ou um ou outro papo de tucano a disfarçar o exotismo norte-europeu do trajo.

\footnotetext{
${ }^{35}$ FREYRE, Gilberto de Mello. Manifesto Regionalista. Organização e apresentação de Fátima Quintas. $7^{\mathrm{a}}$ edição. Recife, FUNDAJ, Ed. Massangana, 1996. Pág. 49.
} 
Primeiro sacrificaram-se as Províncias ao imperialismo da Corte: uma corte afrancesada ou anglicizada. Com a República - esta ianquizada - as Províncias foram substituídas por Estados que passaram a viver em luta entre si ou com a União (...) ${ }^{\text {"36 }}$

Para o foco privilegiado por esta pesquisa, a importância do Manifesto Regionalista está em resgatar o passado judaico no contexto histórico e na formação da cultura brasileira, alijado da história oficial. Até então, o judeu só era lembrado quando se falava da Inquisição, do Antigo Testamento ou para se reproduzir velhos bordões que só serviam para reforçar o preconceito e a discriminação contra o judeu.

É nesta obra que Freyre, em busca das raízes brasileiras, encontra-se com o passado e traz à tona hábitos e traços da cultura de diversos povos que, depois, viriam a formar o povo brasileiro que conhecemos hoje. "(...) em São Paulo e no Paraná, sinais de influência italiana e alguma influência síria ou árabe, além da israelita, presente também no Rio de Janeiro. (...) É claro que a dívida da cozinha brasileira, em geral, e do Nordeste agrário, em particular, às tradições de forno e de fogão de Portugal, é uma dívida imensa. Sem esse lastro, de toucinho e de paio, de grão-de-bico e de couve, bem diversa seria a situação culinária do Brasil. Não haveria unidade nacional sob a variedade regional." 37

Através da construção de um universo lúdico de receitas e culinária, com todas as suas cores, seus sabores e odores, Freyre vai conquistando o leitor e inserindo aos poucos os elementos da cultura judaica que foram assimilados pelos portugueses e pelos brasileiros. "O costume da feijoada dormida parece ter sido assimilado pelo luso-brasileiro, do israelita, amigo desses mistérios por gosto e pela necessidade de esconder certos quitutes como que de ritual ou liturgia, dos olhos de Cristãos Velhos e segundo seus dias de preceito." 38

Mas não é só dos judeus que Freyre trata. Da mesma forma que se refere à culinária judaica, também comenta a culinária moura, monástica, das cunhãs e

\footnotetext{
${ }^{36}$ FREYRE, Gilberto de Mello. Manifesto Regionalista. Organização e apresentação de Fátima Quintas. $7^{\mathrm{a}}$ edição. Recide, FUNDAJ, Ed. Massangana, 1996. Pág. 50.

${ }^{37}$ FREYRE, Gilberto de Mello. Manifesto Regionalista. Organização e apresentação de Fátima Quintas. $7^{\mathrm{a}}$ edição. Recide, FUNDAJ, Ed. Massangana, 1996. Pág. 60 e 61.

${ }^{38}$ FREYRE, Gilberto de Mello. Manifesto Regionalista. Organização e apresentação de Fátima Quintas. $7^{\mathrm{a}}$ edição. Recide, FUNDAJ, Ed. Massangana, 1996. Pág. 61.
} 
negras de Minas. Ou seja, apresenta a contribuição de cada grupo étnico e/ou religioso para a formação dos hábitos e gostos alimentares dos portugueses e brasileiros.

"Todas essas tradições de mesa e sobremesa de Portugal - a cristã, a pagã, a moura, a israelita, a palaciana, a burguesa, a camponesa, a monástica ou fradeca, a freirática - transmitiu-as de algum modo Portugal ao Brasil, onde as matronas portuguesas - é a informação de Gabriel Soares de Souza - não tardaram a aventurar-se a combinações novas com as carnes, os frutos, as ervas e os temperos da terra americana." 39

Ou ainda: "Enquanto isto, foi se mantendo a tradição, vinda de Portugal, de muito quitute mourisco ou africano: o alfenim, o alféloa, o cuscuz, por exemplo. Foram eles se conservando nos tabuleiros ao lado dos brasileirismos: as cocadas - talvez adaptação de doce indiano, as castanhas de caju confeitadas, as rapaduras, os doces secos de caju, o bolo de goma, o munguzá, a pamonha servida em palha de milho, a tapioca seca e molhada, vendida em folha de bananeira, a farinha de castanha em cartucho, o manuê. E o tabuleiro foi se tornando, nas principais cidades do Brasil, e não apenas no Nordeste, expressão de uma arte, uma ciência, uma especialidade das baianas ou das negras: mulheres, quase sempre imensas de gordas que, sentadas à esquina de uma rua ou à sombra de uma igreja, pareciam tornar-se tão corpulentas, o centro da rua ou pátio da igreja." 40

O Manifesto Regionalista lançava uma campanha pela redescoberta das tradições, convidando todos a uma nova percepção da cultura e dos velhos hábitos brasileiros. Usando uma linguagem terna e cativante, Freyre procura buscar valores que ficaram adormecidos em virtude de modismos europeus e pelo próprio esquecimento de certas tradições. O uso da culinária foi a forma utilizada pelo autor para aproximar-se do leitor que, ao entrar em contato com o texto, pode relembrar de velhos doces e guloseimas que o remetem à infância ou a antigos quitutes que, de alguma forma, nos levam a um passado saboroso.

\footnotetext{
${ }^{39}$ FREYRE, Gilberto de Mello. Manifesto Regionalista. Organização e apresentação de Fátima Quintas. $7^{\mathrm{a}}$ edição. Recide, FUNDAJ, Ed. Massangana, 1996. Pág. 62.

${ }^{40}$ FREYRE, Gilberto de Mello. Manifesto Regionalista. Organização e apresentação de Fátima Quintas. $7^{\mathrm{a}}$ edição. Recide, FUNDAJ, Ed. Massangana, 1996. Pág. 63.
} 
Freyre consegue nesta obra resgatar o passado brasileiro, desmistificando a idéia dos primeiros historiadores de que o Brasil era constituído apenas de portugueses, negros e índios. Ele não só insere outros tipos humanos e culturais na composição do povo brasileiro, como prova, através da culinária, as influências que estas outras culturas nos deixaram de herança. E mais, ele desvia a importância do eixo Rio-São Paulo para o Nordeste, onde estas culturas se fizeram mais presentes e onde conseguiram manter mais vivamente velhas tradições.

"Pois o Brasil é isto: combinação, fusão, mistura. O Nordeste, talvez a principal bacia em que se vêm processando essas combinações, essa fusão, essa mistura de sangue e valores que ainda fervem: portugueses, indígenas, espanhóis, franceses, africanos, holandeses, judeus, ingleses, alemães e italianos." 41

Esta obra foi, talvez, uma das primeiras a reconhecer um passado onde existiram judeus que contribuíram para a formação do povo português e brasileiro. Além disto, Freyre insere o judeu ao lado de arábes ou mouros, de portugueses, índios, negros, frades, freiras e outros tipos que, de alguma forma, deixaram um legado na cultura popular do Brasil.

Também merece destaque a forma que emprega para falar desta profusão de povos, pois insere todos os tipos de maneira uniforme, nenhum grupo sendo apresentado como melhor ou pior. Defendendo a cultura nacional, Gilberto Freyre lança um manifesto contra as invasões culturais chegadas da Europa e dos Estados Unidos.

\footnotetext{
${ }^{41}$ FREYRE, Gilberto de Mello. Manifesto Regionalista. Organização e apresentação de Fátima Quintas. $7^{\mathrm{a}}$ edição. Recide, FUNDAJ, Ed. Massangana, 1996. Pág. 72.
} 


\subsection{CASA GRANDE \& SENZALA E SOBRADOS E MUNCAMBOS}

Falar de Gilberto Freyre e de sua obra não é uma tarefa fácil. Primeiro, porque muito já se comentou e pesquisou sobre o autor e seu trabalho; segundo, porque, embora o foco desta pesquisa seja literário, é quase impossível tratar de um antropólogo e de sua obra sem esbarrar nas questões sociais que aborda.

Hoje há uma grande discussão acerca do hibridismo cultural, especialmente na Europa, onde a questão dos imigrantes ocupa lugar de destaque na mídia e na opinião pública. Este assunto é tratado, na maioria das vezes, como um novo campo de estudos ou mesmo como uma recente invenção, esquecendo-se que Freyre estudou o hibridismo cultural há mais de setenta anos. Suas obras mais importantes, Casa Grande \& Senzala e Sobrados e Mucambos, são os maiores exemplos do hibridismo cultural existente em seus estudos.

Segundo os estudiosos Peter Burke e Maria Lúcia Palhares Burke, "Em certo sentido Freyre era um pós-modernista, ele foi um dos primeiros a usar a palavra (hibridismo cultural), nos anos 50, antes de virar moda. Pensava em uma época pósindustrial, em outro sentido, a sociologia não era científica, nem quantitativa, era deliberadamente ensaística. Agora está na moda. Freyre era um pioneiro e o mundo precisa saber disso. " 42

A primeira edição de Sobrados e Mucambos foi publicada em 1936, percebendo-se que se trata de uma continuação de seu trabalho anterior, não havendo uma precisão ou marcação histórica entre as obras, existindo mesmo um certo ar de déjá vu. Quando escreveu Casa Grande \& Senzala, em 1933, Freyre deixou pistas de que o assunto voltaria a ser objeto de estudo, o que ocorreu com o lançamento de Sobrados e Mucambos.

Conforme o próprio autor explica no primeiro capítulo de Sobrados e Mucambos, "O período antes sociológico que cronológico de formação do Brasil que procuramos 
estudar nestas páginas, alongando o esforço de análise e de interpretação empreendido em ensaio já publicado, por um lado continuou um período de integração: durante ele é que se consolidou a sociedade brasileira, (...)" 43

Resultando da mesma linha de pesquisa, Sobrados e Mucambos repete o sucesso de Casa Grande \& Senzala, que, por sua vez, surgiu do desenvolvimento de sua tese universitária de mestrado, apresentada em 1922, "Vida Social no Brasil em Meados do Século XIX". Reeditado várias vezes, Sobrados e Mucambos apresenta características notadamente regionalistas e, como o próprio subtítulo ressalta, trata da história da sociedade patriarcal no Brasil e da decadência do patriarcado rural e do desenvolvimento urbano.

Segundo Ricardo Benzaquen de Araújo, Sobrados e Mucambos trata da "decadência da sociedade patriarcal - agrária, escravocrata e polígama - discutida em Casa Grande \& Senzala. Assim, ao contrário do que acontecia no seu primeiro livro, a passagem do tempo começa, afinal, a trazer mudanças, ainda que esta própria passagem se mantenha 'espacializada', ou seja, percebida e estudada através das modificações sofridas pela arquitetura e pelas formas de sociabilidade doméstica da cultura brasileira." 44

Assim como seus contemporâneos, Gilberto Freyre também sofreu influências da Semana de 22 e do movimento modernista. A distância geográfica, a sua formação diferenciada e as influências regionais fizeram com que o autor modificasse os ecos modernistas que chegaram ao Recife.

Gilberto Freyre está inserido no primeiro período modernista (1922 a 1945) e, para Antônio Cândido, "Ao lado da ficção, o ensaio histórico-sociológico é o desenvolvimento mais interessante do período. A obra de Gilberto Freyre assinala a expressão, neste terreno, das mesmas tendências do Modernismo, a que deu por assim dizer coroamento sistemático, ao estudar com livre fantasia o papel do negro, do índio e do colonizador na formação de uma sociedade ajustada às condições do

\footnotetext{
${ }^{42}$ Matéria publicada no jornal O Estado de Sào Paulo em 30/01/2005, pág. D11.

${ }^{43}$ FREYRE, Gilberto. Sobrados e Mucambos. $4^{\text {a }}$ edição. Rio de Janeiro, José Olympio, 1968 - $1^{\circ}$ tomo, pag. 21.

${ }_{4}^{44}$ ARAÚJO, Ricardo Benzaquen. Guerra e Paz: Casa Grande e Senzala e a obra de Gilberto Freyre nos anos 30.

São Paulo, Editora 34, 1994 - pag. 109.
} 
meio tropical e da economia latifundiária (...)" ${ }^{45}$ É flagrante o tom memorialista impingido por Freyre, em que o conceito de cultura vai aos poucos substituindo o de raça, numa linha já utilizada anteriormente por João Capistrano de Abreu.

É uma obra extensa, que trata das relações humanas no Brasil e que aponta para a formação contemporânea da sociedade brasileira. Além disto, podemos também destacar as imbricações existentes entre o mundo ibérico e o americano, o oriente e o ocidente, as disputas de região e nação, da vida urbana e da rural, os enfrentamentos entre brancos e negros, ricos e pobres, senhores e escravos e, sobretudo, sobre os antagonismos existentes entre a tradição e a modernidade, deixando clara a existência dos hibridismos culturais na formação do português colonizador e do povo brasileiro.

De todas as disputas, talvez a que tenha recebido maior ênfase seja a da vida urbana e da rural, pois mostra o enfraquecimento da aristocracia rural e tradicional e o fortalecimento da aristocracia urbana, em parte pela descoberta e exploração das minas de ouro, que mudou os interesses da Coroa Portuguesa pois tratava-se de uma atividade mais lucrativa.

Esta disputa se acirra com a chegada de D. João VI e sua Corte, que dá mais incentivos ao comércio em detrimento da lavoura, além de desencadear um acentuado processo de urbanização da ex-colônia, contribuindo para enfraquecer, ainda mais, a autoridade e o poder político dos patriarcas rurais.

Também é interessante salientar que, em Sobrados e Mucambos, Freyre mostra o processo de europeização do país, que essa mesma Corte deflagrou a partir de 1808, acentuando a mudança dos hábitos, a vida urbana paulatinamente tomando o espaço da vida rural, as cidades assumindo a relevância e o papel que antes pertencia aos grandes latifúndios rurais.

"Sob o olhar desse ente superior, o brasileiro do século XIX foi abandonando muitos de seus hábitos tradicionais - como o de dançar dentro das igrejas no dia de São Gonçalo, por exemplo - para adotar as maneiras, os estilos e o trem de vida da nova camada de europeus que foram se estabelecendo nas nossas cidades. Desde as

\footnotetext{
${ }^{45}$ CÂNDIDO, Antonio. Literatura e Sociedade. 5 a edição. São Paulo, Cia. Editora Nacional, 1976 - pag. 124.
} 
dentaduras postiças ao uso - até contato maior com os ingleses quase insignificante - do pão e da cerveja" 46

Freyre procura encontrar no passado explicações que ajudem a entender o Brasil contemporâneo, seu povo, suas tradições e culturas, estando a questão antropológica nitidamente ancorada na antropologia norte-americana do início do século passado, influência clara de sua formação.

Freyre aborda a questão da miscigenação e a mobilidade social por ela gerada, sem esquecer que o próprio português, ou "o branco" que aqui chegou, já tinha passado por um processo semelhante de miscigenação, ainda na Europa. Alguns séculos antes, o português e também o espanhol haviam surgido das misturas ocorridas, na própria península Ibérica, entre cristãos, mouros e judeus.

A todo momento o hibridismo cultural vai ocupando seu espaço, onde diferentes culturas vão se fundindo e formando uma nova gente, uma nova cultura, um novo país. E é isto que Gilberto Freyre tenta canalizar e explicar.

Para esta pesquisa, o que nos interessa prioritariamente é a abordagem que o autor faz da presença dos judeus no meio deste cadinho cultural. Em Sobrados e Mucambos, há dezenas de citações, nos capítulos I, II, VII, VIII e IX, que mostram a presença judaica na colônia, especialmente sob o domínio holandês, a importância que teve no comércio internacional, os hábitos que os judeus deixaram para os portugueses e brasileiros, a contribuição no tipo físico e até mesmo do aparecimento das polacas, temas que só recentemente voltaram a ser objeto de estudos nos meios acadêmicos.

\footnotetext{
${ }^{46}$ FREYRE, Gilberto. Sobrados e Mucambos. $12^{\mathrm{a}}$ ed. Rio de Janeiro, Record, 2000. Pág. 335.
} 


\subsubsection{FREYRE E O USO NEGATIVO DA IMAGEM DO JUDEU EM CASA GRANDE \& SENZALA E SOBRADOS E MUCAMBOS}

No primeiro capítulo de Sobrados e Mucambos, Gilberto Freyre começa discutindo a colônia, Dom João VI e, claro, o período do domínio holandês, época em que floresceu o judaísmo em Pernambuco e a descoberta do ouro em Minas Gerais pelos paulistas, "alguns talvez descendentes de judeus." 47

Quando menciona o surgimento das lavouras de cana de açúcar e do nascente comércio nas vilas e cidades, insere aí os negociantes judeus: "Mesmo cheio de riscos, o financiamento à grande lavoura colonial - a de açúcar - atraiu desde cedo agiotas, que parecem ter se dedicado ao mesmo tempo à importação de escravos para as plantações. E há indícios de haver preponderado entre êsses negociantes, judeus com o espírito de aventura comercial aguçado como em nenhuma outra gente. Daí, talvez o relêvo que alguns historiadores - um deles Sombart - dão aos judeus na fundação da lavoura de cana e na indústria do açúcar no Brasil." 48

No trecho acima, Freyre mostra o quanto é dual o conceito do autor para com os judeus, enquanto no final do parágrafo atribui aos judeus a importância de terem sido os precursores da agricultura da cana-de-açúcar e da indústria açucareira no Brasil; no início do mesmo parágrafo, Ihes atribui a pecha de "agiotas", algo muito comum na década de 30 do século passado.

É importante lembrar que foi neste período que surgiram no Brasil obras que tratavam o judeu como agiotas internacionais e aves da rapina. Na terceira década do século XX, muitas obras foram publicadas, no Brasil, com teorias eugênicas e racialistas, sendo um exemplo o livro "Os Protocolos dos Sábios do Sião" 49. Publicado originalmente na Rússia, no início do século XX, ganhou notoriedade após

\footnotetext{
${ }^{47}$ FREYRE, Gilberto. Sobrados e Mucambos. $4^{\text {a }}$ ed. Rio de Janeiro, José Olympio, 1968 - $1^{\circ}$ tomo, pag. 7. ${ }^{48}$ FREYRE, Gilberto. Sobrados e Mucambos. $4^{\text {a }}$ ed. Rio de Janeiro, José Olympio, 1968 - $1^{\circ}$ tomo, pag. 10. ${ }^{49}$ Uma obra inverídica da polícia secreta russa, que criou atas de reuniões fictícias de lideranças judaicas nos últimos anos do século XIX, onde traçariam seus planos para dominar o mundo
} 
1905 e, numa escala internacional, depois da Primeira Guerra Mundial, sendo posteriormente a base do pensamento anti-judaico na Alemanha nazista a partir dos anos 1920.

"João Lúcio de Azevedo, na obra de mestre que é Épocas de Portugal Econômico (Lisboa, 1929), não admite a tese, defendida por Sombart e por historiadores judeus mais ou menos apologéticos de sua raça, de a agricultura da cana, ou antes, da indústria do açúcar, no Brasil, ter sido obra exclusiva, ou principal, de judeus." 50

Na última citação, fica claro o distanciamento existente entre Freyre e o culturalismo boasiano, pois mistura religião e/ou cultura com raça. Uma vez que os judeus e/ou israelitas não poderiam ser tipificados como raça, o que une este povo ou grupo social é a religião. Caso contrário, como explicar a existência de judeus de origem askenazitas, sefarditas, falachas e outros, cada grupo possuindo características físicas diferenciadas, hábitos parecidos mas não iguais.

Esta associação da raça com cultura está muito mais próxima do francês, Vacher de Lapouge ${ }^{51}$, do Conde de Gobineau ${ }^{52}$ e dos teóricos racistas da segunda metade do século XIX, caracterizando-se por seu traço aristocrático. Tais teorias expressavam um certo fatalismo da aristocracia ao sentir-se marginalizada pelos avanços do liberalismo burguês, além da proximidade com o pensamento nazi-fascista, sendo típicas dos partidários do integralismo, como Vicente Rao, Oliveira Viana, Gustavo Barroso e Plínio Salgado, entre outros. Muitos destes autores mantiveram contato com Freyre, havendo mesmo uma troca recíproca de leituras.

É importante salientar que Gustavo Barroso foi um dos pensadores do movimento de direita brasileiro e do integralismo, na década de 30, sendo dele a tradução para o português do livro Os Protocolos dos sábios do Sião. Escreveu, ainda, História Secreta do Brasil; Judaísmo, Maçonaria e Comunismo; A Sinagoga Paulista e O que o Integralista deve saber, entre outras obras de menor importância. É interessante destacar que Barroso atribuía aos judeus a implantação e sustentação do

\footnotetext{
${ }^{50}$ FREYRE, Gilberto. Sobrados e Mucambos. $4^{\mathrm{a}}$ ed. Rio de Janeiro, José Olympio, 1968 - $1^{\circ}$ tomo, pag. 11.

${ }^{51}$ Lapouge ficou conhecido por sua tese $O$ ariano, seu papel social, datada de 1899, levando o naturalismo às últimas conseqüências.

$52 \mathrm{O}$ Conde Arthur de Gobineau viveu no século XIX, tendo ficado conhecido por seu Ensaio sobre a desigualdade das raças humanas, considerado um clássico das teses racistas em voga no século XIX. Afirmava
} 
capitalismo, "cuja intenção era solapar e destruir a boa sociedade tradicional, baseada em valores cristãos e espirituais." 53

No texto de Sobrados e Mucambos, o autor insere várias citações de outros autores importantes, muitos claramente anti-semitas, talvez para conferir um caráter de relevância aos diversos assuntos tratados na obra e/ou transferir tais conceituações para outros intelectuais e não se "comprometer" em demasia com afirmações delicadas.

Sobre o papel dos judeus na colonização brasileira, não poderia ser diferente. Há citações de Max Weber, Sombart , João Lúcio de Azevedo, entre outros. Dentre estas citações, uma de conotação, no mínimo, racialista do historiador português João Lúcio de Azevedo, na obra Épocas de Portugal Econômico (Lisboa, 1929): "Mas é preciso não esquecer, por outro lado, que entre os da família hebréia, dispersos por vários países e em todos êles entregues a formas diversas, mas entrelaçadas, de mercancia e de usura, existia então - como, até certo ponto, existe hoje - uma como maçonaria. Espécie de sociedade secreta de interêsses comerciais, ligados aos da religião ou da raça perseguida, e funcionando com particular eficiência nos momentos de grande adversidade." 54

Prosseguindo com a leitura, nos deparamos com um parágrafo onde o autor cita Max Weber, expondo que: "É bem provável que, expulsos de Portugal, os judeus que tomaram o rumo da terra de Santa Cruz tenham sido amparados fraternalmente por outros, de comunidades prósperas. Daí lhes teria advindo capital, não diremos para iniciativas agrícolas - que estas aqui, como em tôda parte, devem ter repugnado ao seu horror tradicional e canônico (a expressão é de Max Weber) pela terra e a sua política calculada de aventura comercial em países cujo solo sentiam não Ihes pertencer (...)". ${ }^{55}$

Vale salientar que tanto Weber quanto Sombart, se não eram anti-semitas também não eram muito simpáticos para com os judeus. O discurso nazista utilizou-se da

\footnotetext{
a superioridade inconteste da raça branca, bem como determinava as distinções sociais entre nobreza, burguesia e povo, de acordo com sua maior ou menor participação no sangue ariano.

${ }^{53}$ MOTTA, Rodrigo Patto Sá. O mito da conspiração judaico comunista. In Revista de História, número 138, São Paulo, Humanitas, 1998 - pág. 99.

${ }^{54}$ FREYRE, Gilberto. Sobrados e Mucambos. $4^{\text {a }}$ ed. Rio de Janeiro, José Olympio, 1968 - $1^{\circ}$ tomo, pag. 11 - 12.

${ }^{55}$ FREYRE, Gilberto. Sobrados e Mucambos. $4^{\text {a }}$ ed. Rio de Janeiro, José Olympio, 1968 - $1^{\circ}$ tomo, pag. 12.
} 
obra destes conhecidos autores para fundamentar suas teorias racistas e o arianismo presente no seu conteúdo. O destaque é que o autor usa o texto de Weber para ratificar os mitos de que os judeus não se fixam na terra, possuem horror à agricultura e não têm raízes em lugar algum.

Ao comparar a figura do judeu com a do português (se é que podemos dissociar a figura do judeu da do português), Freyre assume cada vez mais uma postura muito próxima da do discurso integralista e/ou nazista: " A figura do judeu não teve essa grandeza de criador, com um sentido profundo de permanência a animar-lhe o esfôrço. Ao contrário: viveu à sombra do português patriarcal. E quase sempre móvel e provisório nos lugares. Tanto que no Brasil muitos israelitas aqui enriquecidos se transferiram a outras áreas da América. “ 56

O que podemos perceber é que Freyre sempre relata a presença marcante do judeu na vida colonial brasileira, atribuindo-lhe a importância quando lhe é devida, porém geralmente associada a adjetivos de caráter depreciativos, como agiota, gente encoberta, usurário, parasita e outros. Um outro exemplo: "ajustes de que falam tantas tradições de família - parece ter sido, em grande parte, conseqüência das fortunas acumuladas pelos intermediários e negociantes, alguns de origem israelita. (...) O intermediário viveu como médico de um doente a quem explorasse, dessas feridas conservadas abertas." 57

Como já foi mencionado anteriormente, o discurso de Freyre, especialmente no primeiro capítulo do livro, está muito próximo do pensamento da direita brasileira. Mas não é só isto, se compararmos com Mein Kampf (Minha Luta) de Adolf Hitler, perceberemos que as citações anteriores apresentam certa similaridade com o discurso presente no livro de Hitler.

"O judeu não satisfaz à condição prévia mais essencial para um povo civilizador: não tem idealismo (...) É e permanece o parasita típico, o papa jantares que, qual nocivo bacilo, se espalha sempre para mais longe (...) Envenena o sangue dos outros, mas preserva o seu inalterado (...)" 58

\footnotetext{
${ }^{56}$ FREYRE, Gilberto. Sobrados e Mucambos. $4^{\text {a }}$ ed. Rio de Janeiro, José Olympio, 1968 - $1^{\circ}$ tomo, pag. 13.

${ }^{57}$ FREYRE, Gilberto. Sobrados e Mucambos. $4^{\text {a }}$ ed. Rio de Janeiro, José Olympio. 1968 - $1^{\circ}$ tomo, pag. 10.

${ }^{58}$ HITLER, Adolf. Mein Kampf. Paris, Nouvelles Éditions Latines, S.D. - pag 301 - 325.
} 
Gilberto Freyre foi por diversas vezes acusado de difusor do anti-semitismo, sendo sua obra estudada por alguns sociólogos e antropólogos, como Darcy Ribeiro e Julio José Chiavenato, que apontaram a presença do anti-semitismo em seus livros e ensaios.

No livro Ensaios Insólitos, Darcy Ribeiro comenta o retrato feito dos judeus na obra Casa Grande \& Senzala de Freyre, o que se encaixa nas duas obras (Sobrados e Mucambos e Casa Grande \& Senzala), extremamente ligadas e com conteúdo muito parecido, conforme já foi mencionado e havendo, inclusive, passagens idênticas entre os dois títulos.

Assim, o sociólogo e ensaista Darcy Ribeiro observa o tratamento dispensado aos judeus: "Do judeu, ao contrário, o retrato é caricaturesco e impiedoso. Assinala, primeiro, que a sanha anti-semita dos lusitanos não seria racismo, mas simples intolerância em defesa da fé. Salienta, de resto, que isto seria muito explicável, uma vez que o judeu de Portugal tanto se mimetizou e assimilou, que acabou deslembrado de si, como cristão-novo, oriundo de conversões velhas, de séculos. Carecia-se, por isto, descobrir, denunciar e desentocar esses desmemoriados semitas para evitar que recaíssem em judiarias. A odiosidade ao semita viria da ojeriza ao agiota frio, sugando o povo lusitano em proveito próprio, de reis ou de nobre." 59

Em outra citação de Sobrados e Mucambos, Freyre insere os termos "homem da nação" e "mascates", quando se refere aos judeus. "Mascates que por êsses lucros de cento por cento se faziam 'riquíssimos'. Bradônio refere ainda nos Diálogos o caso, que parece também arte de 'homem da nação' ou de cidade que explorasse velhacamente matutos - arte, que depois, tanto se desenvolveu nos negócios de açúcar, de ouro e de café - de comprar um espertalhão (...)" 60

No prefácio do livro Inquisição: rol dos culpados, de Anita Novinsky, Joseph Eskenazi Pernidji explica o significado do termo "homem da nação": O termo homem da nação ou "Gente da Nação é o nome que se dava aos cristãos-novos, isto é, da Nação Hebraica: assim foram conhecidos pelos quatro cantos do mundo, e

\footnotetext{
${ }^{59}$ RIBEIRO, Darcy. Ensaios Insólitos. Porto Alegre, L\&PM, 1979 - pag. 84.

${ }^{60}$ FREYRE, Gilberto. Sobrados e Mucambos. $4^{\text {a }}$ ed. Rio de Janeiro, José Olympio. 1968 - $1^{\circ}$ tomo, pag. 13 e 14
} 
durante os séculos XVII (...)" ${ }^{61} \mathrm{E}$ tudo indica que o termo permaneceu vivo no imaginário e na memória do povo e foi novamente transcrito para livros através de Freyre.

Pelas citações e comentários apontados nesta parte, poderíamos aplicar imediatamente um rótulo ao autor, "anti-semita". O uso de termos e frases estereotipadas transforma-se em elemento indicativo de uma situação que aponta para um pensamento racista. Porém, antes de emitir qualquer parecer sobre o tema é prudente avançar com a leitura do livro, seguir para o capítulo VII, para, posteriormente, apresentar alguma conclusão sobre o assunto.

\footnotetext{
${ }^{61}$ NOVINSKY, Anita Waingort. Inquisição: rol dos culpados: fontes para a história do Brasil(século XVIII). Rio de Janeiro, Expressão Cultural, 1992 - Prefácio pag. VIII.
} 


\subsubsection{FREYRE E A VISÃO POSITIVA DOS JUDEUS EM CASA GRANDE \& SENZALA E SOBRADOS E MUCAMBOS}

Como já foi dito antes, tanto Casa Grande \& Senzala como Sobrados e Mucambos apresentam uma dualidade, com visões antagônicas sobre os judeus. Em alguns trechos, o autor demonstra certa simpatia para com os judeus, como no trecho a seguir: "E muito fidalgo de casa-grande do interior foi caloteiro em tôda a extensão da palavra; e não vítima dos judeus da cidade." 62 Esta passagem é uma das que amenizam as críticas a Freyre.

Assim, não há uma unanimidade entre os estudiosos do autor, havendo quem refute a idéia de que exista uma perspectiva anti-semita em sua obra. Segundo o cientista político da Fundação Oswaldo Cruz, Marcos Chor Maio: "Ainda que a narrativa do sociólogo seja com freqüência ambígua, imprecisa e conquanto utilize por vezes uma linguagem racialista, sugiro que o argumento substantivo de Freyre, informado pela concepção neolamarckiana de raça e pelo enfoque weberiano acerca dos fundamentos do capitalismo moderno, leve à incorporação positiva dos judeus à nova sociedade criada no Brasil." 63

O que é certo é que Freyre, diferentemente de outros autores brasileiros de sua época, estudou na América e não na Europa como os demais. Na universidade, conheceu e foi, além de aluno, amigo de Franz Boas, que era judeu; também manteve contatos com Isaac Goldemberg e Leon Kobrin, ambos judeus.

"Foi Isaac Goldemberg quem deu a Gilberto Freyre uma idéia da literatura ídiche, Leon Kobrin, David Pinsky e outros (...) Foi em seguida Kobrin o apresentador de

\footnotetext{
${ }^{62}$ FREYRE, Gilberto. Sobrados e Mucambos. $4^{\text {a }}$ ed. Rio de Janeiro, José Olympio. 1968 - $1^{\circ}$ tomo, pag. 19.

${ }^{63}$ MAIO, Marcos Chor. Estoque Semita: A presença dos judeus em Casa-Grande \& Senzala. In Luso Brazilian Review, vol. 36, № 1. Wiscosin-EUA, University Wisconsin Press, 1999 - pág. 96.
} 
íntimas imagens de Trotsky, outro Leon, ao Gilberto deslumbrado com tantas iniciações novaiorquinas (...)." 64

O que podemos perceber é que nos dois primeiros capítulos do livro, o autor dá um tratamento diferenciado aos judeus, de caráter extremamente pesado e nitidamente anti-semita, sendo amenizado nos capítulos seguintes, o que leva um leitor mais atento a supor que nem todos os capítulos foram escritos no mesmo período, ou que a posição do autor em relação aos judeus oscilava.

No capítulo VII, a impressão que surge é altamente positiva. Freyre demonstra certa simpatia e apreço pelo judaísmo, parecendo rememorar boas recordações infantis de Recife, falando de brincadeiras de criança, de culinária, de orações e muito mais, o que nos remete diretamente ao Manifesto Regionalista, de 1926.

Demonstrando ter muitos conhecimentos do cotidiano da vida judaica e do judaísmo, Freyre tratou dos marranos, dos cristãos novos, dos sefarditas (judeus oriundos de Espanha e Portugal) e dos ashkenazitas (judeus do Norte da Europa, Europa Central e Oriental).

Assim, é interessante perceber que no início do livro o judeu é retratado como o agiota internacional para, posteriormente, receber elogios a sua tenacidade, cultura e conhecimentos de medicina. Conforme segue:

"Se na Bahia desenvolveu-se o primeiro centro de cultura médica no Brasil, é que na cidade de Salvador, já no século XVII, encantavam-se à sombra das igrejas cheias de Nossas Senhoras maternalmente gordas e de santos triunfantes, marranos peritos na ciência de tratar dos doentes e que receitavam carne de porco para que nenhum volutuoso de delação desconfiasse deles. A medicina foi sempre uma especialização muito dos sefardins; seu meio de competir com os padres confessores e os capelães na influência sobre as grandes famílias dos países cristãos e a gente poderosa dos governos. Foram decerto eles que a trouxeram para o Brasil, nas suas formas mais adiantadas, e a desenvolveram na Bahia e no Recife. Do Recife sairia Velozino, um dos maiores médicos judeus do século XVII" 65

\footnotetext{
${ }^{64}$ CHACON, Vamireh. Gilberto Freyre: uma biografia intelectual. Recife/São Paulo, Massagarana/Nacional, 1993 - pág. 99 e 100.

${ }^{65}$ FREYRE, Gilberto. Sobrados e Mucambos. 12ª edição. Rio de Janeiro, Record, 2000 - pag. 346.
} 
Seguindo no capítulo VII, o autor fala também do período de domínio holandês e da liberdade religiosa que existia na época (1630 a 1654). "Nesse Recife que se diferenciou tanto das outras cidades da colônia pelo seu gênero de vida e pela sua população desigual de neerlandeses, franceses, alemães, judeus, católicos, protestantes, negros e cablocos, não só se falaram, por trinta anos, quase todas as línguas vivas da Europa e várias da África, como estudou-se e escreveu-se nas sinagogas um hebreu diverso do manchado e gasto pela boca dos Ashkenazim: o velho e aristocrático hebreu guardado em toda a sua pureza pelos rabinos de barba preta e olhos tristes que a Congregação de Amsterdã mandara para Pernambuco." 66

Além da medicina e do hebraico falado nas sinagogas, Freyre se deteve também em aspectos mais particulares da vida judaica, como culinária e hábitos religiosos, conforme segue: "Nas cozinhas dos sobrados, com a liberdade que Nassau deu aos Judeus, cozinhou-se, decerto, muito quitute israelita e é possível que dos hebreus nos tenha vindo o hábito da feijoada dormida, isto é, do alimento preparado de véspera e como que encoberto, guardado, dormido; nos quintais, debaixo dos cajueiros, criaram-se carneiros e engordaram-se galinhas para serem sacrificadas e preparadas, segundo o rito de Moisés, e comidas nos dias de preceito, com o pão da Páscoa e as ervas picantes. E nos fundos das lojas, e até em público, adorou-se o Deus de Israel; praticou-se o Judaísmo. E é possível que até a Cabala, tão do gosto dos sefardins de imaginação mais ardente." 67

Mais adiante, o autor fala de religiões, não só de judaísmo ou catolicísmo, mas das principais vertentes religiosas que povoaram e povoam, ainda hoje, o Brasil. Seus comentários sobre religião mostram, além da liberdade religiosa vigente, as imbricações que houveram no Recife Holandês.

"Circuncidaram-se meninos. Recitaram-se, nem sempre em voz baixa nem de medo, piyyutim ${ }^{68}$ saudosos. Talvez à mesma hora em que dentro das igrejas papistas e até

\footnotetext{
${ }^{66}$ FREYRE, Gilberto. Sobrados e Mucambos. 12a edição. Rio de Janeiro, Record, 2000 - pag. 347.

${ }^{67}$ FREYRE, Gilberto. Sobrados e Mucambos. 12a edição. Rio de Janeiro, Record, 2000 - pag. 347.

${ }^{68}$ Poemas e hinos cantados na sinagogas, muitos dos quais foram compostos na Idade Média e incorporados a liturgia. Em geral refletem momentos históricos como as cruzadas, perseguições e outros acotencimentos ligados
} 
na rua, em procissões que saíam com licença do Conde, se entoassem louvores em latim à Virgem Maria e ao Menino Jesus; e nas capelas dos reformados, os crentes cantassem em holandês, francês ou inglês, hinos glorificando outro Deus: o de São Paulo e de Calvino. Enquanto dos matos mais próximos, dos mucambos dos mangues, chegava até às igrejas e às sinagogas de pedra e cal, a assuada de alguma 'santidade' de índios ou o alarido de bandos de negros de Xangô ou Santa Bárbara adorada à africana; loas pedindo ao céu milho que desse para encher as cuias; outras encomendando aos santos algum defunto; as mais atrevidas, chamando Exu." 69

Tais citações reforçam, em muito, as teses dos defensores de Freyre, pois neste trecho do livro não são encontradas referências anti-semitas ou racialistas, havendo um reencontro do autor com o judaísmo e com as demais culturas (minoritárias) que compuseram o Brasil Colonial. É interessante notar que o autor coloca as palavras judeus, judaísmo e cabala com letras maiúsculas, mesmo não se tratando de nomes próprios.

Ainda sobre o capítulo VII, de Sobrados e Mucambos, o autor faz mais elogios ao legado deixado pelos judeus no Brasil:

“(...) foi um dos países mais beneficiados pelo comércio internacional dos Judeus. Beneficiado pelo que o Judeu pôde oferecer de mais substancioso à América, em valores de cultura e em estímulos aos nosso desenvolvimento intelectual.

Através dos doutores e dos mestres que a congregação de Amsterdã mandou para o Recife e para Salvador, o Brasil recebeu da velha cultura sefárdica soma considerável de elementos de valor. Valor científico. Valor intelectual. Valor técnico." 70

Seguindo no texto de Sobrados e Mucambos, o autor volta à questão dos benefícios comerciais deixados pelos judeus, das garras da inquisição e da diáspora ocorrida na Península Ibérica, em um longo trecho, conforme transcrevo nos próximos quatro parágrafos:

ao povo judeu. Alguns poemas também falam de questões rituais ou puramente espirituais (ver o verbete piut no Dicionário Judaico de Lendas e Tradições).

${ }^{69}$ FREYRE, Gilberto. Sobrados e Mucambos. 12a edição. Rio de Janeiro, Record, 2000 - pag. 347 e 348.

${ }^{70}$ FREYRE, Gilberto. Sobrados e Mucambos. 12a edição. Rio de Janeiro, Record, 2000 - pag. 353. 
"O que o Judeu trouxe para o Brasil como elemento de diferenciação foi principalmente a capacidade para o comércio internacional, que nos enriqueceria de uma variedade de contatos, impossíveis dentro da exclusividade portuguesa. Também a especialização científica e literária que neles se aguçara por efeito daquela riqueza de contatos, distanciando-se dos portugueses rurais e cristãosvelhos. Especialização que se aguçara não só no exílio como nas próprias Espanhas quando, excluídos da política e da carreira militar, acharam compensação para o recalque dos seus desejos de glória e de triunfo pessoal ou de família ou raça, nas carreiras intelectuais e científicas: a Medicina, o Professorado, a literatura, um pouco a Matemática e a filosofia. Pais negociantes e filhos doutores - tal foi, em Portugal, o seu processo de ascensão social.

Dispersos pelo norte da Europa, pelas repúblicas italianas, pelo Levante, pela África, os Sefardins que a Inquisição enxotara das Espanhas, onde quer que se fixaram, foram estabelecendo relações comerciais uns com os outros e assim desenvolvendo um grande comércio internacional. Dos benefícios desse sistema de relações internacionais é que o Brasil veio a participar, um pouco no século XVII e outro tanto no século XVIII, comunicando-se, pelos judeus, com a Holanda e com a Inglaterra, com o Levante e com as Repúblicas Italianas.

Assim se explica, em grande parte, o surto cultural, tanto em Pernambuco, naquele primeiro século - onde a força de diferenciação dos Judeus se juntou à dos holandeses, ou mais rigorosamente, à de Maurício de Nassau - como, até certo ponto, nas cidades mineiras do século XVIII - onde a infiltração israelita foi decerto menos ostensiva e talvez mais comercial que social e intelectual. Em Pernambuco, supõem alguns ter sido judeu o próprio Bento Teixeira Pinto. Judeu, o primeiro poeta que cantou no século XVI as belezas do Brasil e as glórias de Portugal.

No sul - principalmente em Minas Gerais - algumas das melhores famílias antigas, com olhos, nariz ou beiços que são clássicos, do semita, autorizam-nos a supor larga infiltração de sangue judaico na velha região dos diamantes. Pelas crônicas se sabe que não foram poucos os indivíduos e até as famílias inteiras, residentes na 
capitania das Minas - principalmente em Vila Rica, Serro Frio e Paracatu condenadas pela Santa Inquisição por culpas de Judaísmo. “ 71

Após este último trecho citado, o autor segue descrevendo alguns dos indivíduos presos pela inquisição. Freyre menciona alguns nomes e tal procedimento reforça o ineditismo de sua obra, uma vez que utilizou fontes até então desconhecidas para aquela época.

Além destas citações Gilberto Freyre também tece comentários sobre o início da prostituição e a chegada das "polacas" 72 ao país. "Para reduzir ou extinguir a prostituição masculina no baixo comércio, predominantemente lusitano, do Rio de Janeiro é que o Cônsul de Portugal na mesma cidade, Barão de Moreira, teria promovido, em 1846, a importação de mulheres ilhoas. Seriam elas sucedidas pelas polacas e francesas, cujo perfil procuraremos traçar em estudo próximo." 73

Freyre realmente retomou o tema na introdução da obra $O$ Velho Félixe suas Memórias de um Cavalcanti, onde retoma o assunto com um pouco mais de conteúdo (ver ficha $\mathrm{n}^{\circ} 038$ e o título seguinte da pesquisa), posteriormente, lançou em 1959 o livro Ordem e Progresso e, em seu capítulo 1, também volta a tratar do assunto.

Esta última citação não se enquadra nem como positiva, nem tão pouco como negativa, apenas possui um grande caráter informativo, histórico e social, pois pontua o aparecimento de um fenômeno que marcou época na sociedade. Muito posteriormente, o termo polaca perdeu a conotação depreciativa de prostituta e passou a ser sinônimo de mulher que tivesse ou usasse cabelos loiros, na gíria popular.

Como se pode acompanhar nas últimas citações extraídas de Sobrados e Mucambos, Freyre, no capítulo VII, trata os judeus de maneira positiva, agregandoIhes valor e, sobretudo, colocando-os como participantes ativos da história brasileira

\footnotetext{
${ }^{71}$ FREYRE, Gilberto. Sobrados e Mucambos. 12a ed. Rio de Janeiro, Record, 2000 - pag. 354 e 355.

${ }^{72}$ As polacas eram mulheres judias, aliciadas em sua maioria na Europa Central e Oriental, que migravam para o Brasil e outros países com o intuito de arrumar bons casamentos ou oportunidades de trabalho, porém quando chegavam ao destino é que ficavam sabendo para que realmente tinham sido chamadas, a prostituição. Um verdadeiro comércio de escravas brancas. Aqui se concentraram principalmente em Recife, Rio de Janeiro e São Paulo. Há estudos relacionados ao tema feito pelos Professores Boris Fausto no livro Ócios e negócios e Ester Largman no livro Jovens Polacas.
} 
e também portuguesa. O judeu não está à frente ou atrás de nenhum outro tipo social, mas sim ao lado de todos os demais protagonistas que compuseram a nossa história.

Outro ponto que merece destaque é o fato de Gilberto Freyre, além de se referir de maneira ácida contra os judeus, em alguns trechos de Casa Grande \& Senzala, também critica outros grupos étnicos/religiosos, não poupando ninguém.

"No século XVI, com exceção dos jesuítas - donzelões intransigentes - padres e frades de ordens mais relassas em grande número se amancebaram com índias e negras; os clérigos de Pernambuco e Bahia escandalizando o Padre Nóbrega. Através dos séculos XVII e XVIII e grande parte do XIX continuou o livre arregaçar de batinas para o desempenho de funções quase patriarcais, quando não para excessos de libertinagem com negras e mulatas." 74

O mesmo ocorreu contra o branco europeu no tratar com os escravos: "Ao muleque companheiro de brinquedo do menino branco e seu leva pancadas (...)Crescem juntos e o escravo torna-se um objeto sobre o qual o menino exerce seus caprichos $(\ldots) " 75$

E o que dizer do próximo comentário, também extraído de Casa Grande \& Senzala, dirigido às mulheres índias e aos europeus brancos que desembarcavam no Brasil: "O Europeu saltava em terra escorregando em índia nua; os próprios padres da Companhia precisavam descer com cuidado, senão atolavam o pé na carne. Muitos clérigos, dos outros, deixaram-se contaminar pela devassidão. Mulheres eram as primeiras a se entregarem aos brancos, as mais ardentes indo esfregar-se nas pernas desses que supunham deuses. Davam-se ao europeu por um pente ou um caco de espelho." 76

Lendo a Obra de Freyre, podemos notar, a todo momento, que este elege este ou aquele grupo étnico/religioso para tecer seus comentários mordazes, assim o que se percebe é que o judeu foi muito criticado, mas não só o judeu, todos os demais

\footnotetext{
${ }^{73}$ FREYRE, Gilberto. Sobrados e Mucambos. $4^{\mathrm{a}}$ ed. Rio de Janeiro, José Olympio. 1968 - $1^{\circ}$ tomo, pag. 159.

${ }^{74}$ FREYRE, Gilberto. Casa Grande \& Senzala. 34a ed. Rio de Janeiro, Record. 1992. Pag. 443.

${ }^{75}$ FREYRE, Gilberto. Casa Grande \& Senzala. 34a ed. Rio de Janeiro, Record. 1992. Pag. 336.

${ }^{76}$ FREYRE, Gilberto. Casa Grande \& Senzala. 34 ed. Rio de Janeiro, Record. 1992. Pag. 93.
} 
elementos que formaram e deram origem à sociedade brasileira também foram alfinetados.

Portanto, não é possível dizer que Freyre foi um autor anti-semita ou nitidamente contrário aos judeus, ou ainda que tenha alimentado a propaganda anti-semita da conturbada década de 30. Mas também não seria possível afirmar que era um ardoroso defensor da comunidade judaica. O que merece destaque é o fato de ter introduzido o judeu na história oficial do país, recolocando-o ao lado de negros, índios, portugueses, holandeses e uma infinidade de etnias que deram origem ao brasileiro que conhecemos hoje. 


\subsection{O VELHO FÉLIX E SUAS MEMÓRIAS DE UM CAVALCANTI}

A obra Memórias de um Cavalcanti teve sua primeira edição datada de 1940, sendo este 0 título da $1^{\mathrm{a}}$ edição, posteriormente alterado para $O$ velho Félix e suas memórias de um Cavalcanti.

Esta pesquisa utilizou a $2^{a}$ edição, publicada em 1959, e que traz, na introdução, uma descrição sobre a vida das prostitutas judias, dos cafetões e como funcionou, desde o final do século XIX, a prostituição no Rio de Janeiro.

O tema, de certa forma, não é novidade, pois o próprio autor já havia feito uma pequena abordagem sobre o assunto no livro Sobrados e Mucambos, onde conta como se institucionalizou a prostituição feminina na corte, o ano que chegaram as primeiras prostitutas etc., mas este ralato não preenchia mais que uma página.

Apesar de não ser um relato muito extenso, com poucas páginas dedicadas ao assunto, Gilberto Freyre faz uma abordagem significativa, tecendo comentários, inclusive, sobre sua fonte, a obra O Lupanar: estudo sôbre o caftismo e a prostituição no Rio de Janeiro, escrito por Ferreira da Rosa, e publicado em 1896, no Rio de Janeiro.

Segundo Freyre, a obra já estava quase ignorada nos meios acadêmicos e intelectuais, tendo sido resgatada do obscurantismo por ele. Assim, Freyre lastreado por Ferreira da Rosa, descreve os dissabores e a difícil vida das prostitutas judias na fronteira dos séculos XIX e XX.

Ferreira da Rosa utiliza-se de cartas e outros documentos pessoais destas prostitutas e cafetões para traçar situações sociais e psico-sociais, que são alinhavadas com entrevistas dos próprios agentes dos fatos ali relatados.

"Mas também se encontra no livro de Ferreira da Rosa documentos pessoais com esta tradução de um fragmento de carta escrita em hebraico em 1896, de Moscou para o Rio, por Jacob lacowitz ao seu filho Salomão, caften no Brasil: Desculpa-me 
por te escrever esta carta mas tenho o coração torturado. Chegaram diversas pessoas ao nosso país e o que dizem de ti faz-me crer que são teus inimigos; se fôssem amigos não falariam tão mal. Desejo saber, portanto, em que te ocupas na América do Sul, qual o gênero de negócios de que vives, enfim. Responde às perguntas que aqui te faço sôbre o teu meio de vida, e isso te peço por favor: dizeme também como passas de saúde, a tua mulher e o teu filho. Recebe lembranças de João, Raquel, de todos os teus amigos e de tua mãe. Teu pai Jacob lacowitz." 77 Há também um trecho onde descreve o conteúdo de uma carta escrita pela prostituta Klara Adam, publicada primeiramente no jornal Gazeta de Notícias, em 22/04/1880, e utilizada posteriormente por Ferreira da Rosa em sua obra. Freyre acabou por fazer uma transcrição de seu conteúdo em seu livro O Velho Félix.

“(..) em 1878 vivia eu em Brieg, na Prussia, em casa de meus queridos pais. Pobre mas honrada fui contratada por Siegmond Richer e sua mulher Augusta Joana ou Leonor Jacobowitz para vir trabalhar com costureira numa loja de modas que eles diziam possuir no Brasil, asseverando-me que, com o meu trabalho assíduo e honesto, tiraria grandes lucros, faria fortuna, podendo casar-me e ser muito feliz. Assim acreditando na seriedade de tais promessas e em que m'as fazia, deixei minha mãe e irmãozinhos e parti em companhia de Siegmond e de sua mulher para Marselha, onde devíamos esperar o paquete para o Brasil. Mas em Marselha aguardava-me a mais terrível das desgraças. No hotel para onde fomos, achavamse diferentes caftens também esperando o paquete e entre eles José Catze foi o escolhido por Siegmond para perder-me, e uma noite, com um poderoso narcótico, fui miseravelmente deshonrada por este infame (...) Este fato acha-se descrito no inquérito a que ultimamente procederam a respeito dos crimes dos caftens os ilustrados Drs. Bulhões e Felix da Costa. (...)" 78

A descrição das desventuras de Klara Adam continua por um longo parágrafo e, mais adiante, conta como fugiu das mãos do cafetão, a carta que este escreu a sua mãe e a colocou em uma cama adoentada para o resto da vida.

\footnotetext{
${ }^{77}$ FREYRE, Gilberto. O Velho Félix e suas memórias de um Cavalcanti. Rio de Janeiro, José Olympio, 1959. Pág. CXV.

${ }^{78}$ FREYRE, Gilberto. O Velho Félix e suas memórias de um Cavalcanti. Rio de Janeiro, José Olympio, 1959. Pág. CXVI.
} 
Depois, aparece uma entrevista com um cafetão de nome Adolpho Gluck, mais alguns relatos sobre outros cafetões, prostitutas e a corrupção das autoridades policiais que sabiam de tudo e não tomavam qualquer providência.

Também merece destaque a maneira do autor tratar da prostituição feminina e masculina em Recife, sua cidade natal, fornecendo inclusive sua fonte de pesquisa, um jornal do século XIX chamado O Binóculo: "Embora sem caftismo, sem polacas e mesmo sem francesas que fôssem vulgares sacerdotisas do amor a serviço de nojentos patrões; embora entusiasmando-se por estrangeiras sacerdotisas da arte, o Recife do tempo de Félix não era nenhuma cidade-môdelo do ponto de vista da moral sexual. Muita era a prostituição de mulheres de côr. A própria prostituição masculina dava-Ihe certo ar de Sodoma crioula. Vem o mal denunciado em $O$ Binóculo de 4 de janeiro de 1888, onde também se acusa de vir desenvolvendo no Recife êsse gênero de prostituição, que já contaminara moços inexperientes e fáceis na catequese, certo monstro de naturalidade estrangeira ou portuguêsa." 79 


\subsection{OS GUIAS PRÁTICOS, HISTÓRICOS E SENTIMENTAIS DE CIDADES BRASILEIRAS}

Os guias práticos de cidades, duas obras que tratam especificamente de Olinda e Recife, foram publicados em 1939 e 1934, respectivamente.

O Guia Prático, Histórico e Sentimental da Cidade do Recife possui muito do que o autor já havia apresentado em Casa Grande \& Senzala (1933), praticamente um resumo, ricamente ilustrado por Luís Jardim.

Fala dos "israelitas" em pouco mais de duas páginas, faz a diferenciação entre sefaraditas e asquenazitas, da fundação de Nova lorque pelos judeus brasileiros, explusos do Brasil em 1654, junto com os holandeses.

"Os israelitas - os vindos da Europa Central, principalmente, e não mais sefardins, como outrora - recomeçam a ser numerosos no Recife: cidade da qual foram no século XVII parte considerável da população e de onde, há três séculos, seguiram para a então Nova Amsterdã, hoje Nova Iorque, os vinte e quatro judeus que com suas famílias fundaram ali uma comunidade de sefardins de origem ibérica que se tornou ilustre. De sefardins descendem norte-americanos eminentes na vida-pública, nas letras e nas indústrias dos Estados Unidos, uns com os nomes ainda portuguêses de Cardozo, outros com êsses nomes anglo-saxonizados." 80

Seguindo a mesma receita básica, Freyre irá publicar em 1939 o segundo guia de cidades. O livro Olinda - 20 Guia Prático, Histórico e Sentimental de Cidade Brasileira, ilustrado por Manuel Bandeira, também trata dos judeus em Pernambuco, mais especificamente na cidade de Olinda, em um curto parágrafo, onde comenta a construção de duas sinagogas no tempo de Nassau.

\footnotetext{
${ }^{79}$ FREYRE, Gilberto. O Velho Félix e suas memórias de um Cavalcanti. Rio de Janeiro, José Olympio, 1959. Pág. CXXV.

${ }^{80}$ FREYRE, Gilberto. Guia prático, histórico e sentimental da cidade do Recife. $4{ }^{\text {a }}$ Edição. Rio de Janeiro, José Olympio, 1968. Pág. 141.
} 
"O sino que tinha a legenda Salvator mundi salve me era talvez da Matriz do Salvador - hoje catedral - que os holandeses, por picardia à Olinda católica, transfomaram em templo calvinista, oficiando aí o ministro Baers. Mas parece que nem os calvinistas nem os judeus se expandiram tão à vontade em Olinda - mesmo depis que as igrejas ficaram mudas, sem os seus grandes sinos de bronze para protestar contra a invasão dos hereges - como no Recife. Aí, os israelitas levantaram duas sinagogas; chegaram a namorar o próprio Palácio das Tôrres do Conde Maurício de nassau para nêle instalarem também uma sinagoga, que seria de uma opulência única; construíram cemitério para a gente de sua religião." 81

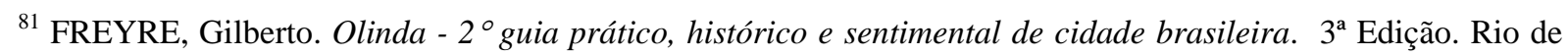
Janeiro, José Olympio, 1960. Pág. 112 e 113.
} 


\subsection{DEMAIS OBRAS DE FREYRE NO PERÍODO}

Ainda dentro do período em estudo, Gilberto Freyre publicou Retalho de Jornais Velhos em 1935, Nordeste em 1937, O Mundo que o Português Criou, em 1938 e Um Engenheiro Francês no Brasil em 1940.

Estas são obras de menor importância, tendo em vista a grandiosidade de Casa Grande \& Senzala e Sobrados e Mucambos e, para o foco privilegiado por esta dissertação de mestrado, não acrescentam muito à pesquisa.

Em todas as obra mencionadas no primeiro parágrafo deste capítulo, existem citações que remetem à cultura e/ou personalidades da comunidade judaica, o que ocorre, porém, de forma muito pontual ou apresentando pouca relavância.

Entre as citações, destacam-se, em Retalho de Jornais Velhos, a visita de Einstein ao Brasil e o fato do autor o identificar como um membro da comunidade judaica (página 119). O texto do livro fora originalmente escrito como matérias jornalísticas para o Diário de Pernambuco.

$\mathrm{Na}$ obra Nordeste, existem poucos elementos que realmente interessam à pesquisa, exceto alguns comentários sobre Samuel Hardman, que estudou a pecuaria e a agricultura da região nordeste do Brasil.

Em O Mundo que o Português Criou, merece destaque o fato de comentar as etnias que migraram para o Brasil desde o final do século XIX, alemães, poloneses, italianos, japoneses, judeus e tantos outros. também fala sobre o aculturamento destes imigrantes e seu "abrasileiramento", citando os professores Meville J. Herskovits e Claude Lévy Strauss.

É muito interessante ler este último livro e, em seguida, a obra de Manuel Diégues Junior, Etnias e Culturas no Brasil, pois o leitor terá uma clara visão de como este autor foi influenciado por Freyre, existindo uma grande similaridade entre os dois trabalhos. 
Quanto à obra Um Engenheiro Francês no Brasil, percebe-se no texto uma forte tendência anti-semita: aqui, o autor se refere aos judeus de forma um tanto pejorativa e inclui citações de outros autores que se referem ao judeu de maneira semelhante ou ainda pior.

Em 1940, quando Freyre publicou pela primeira vez este livro, o Brasil atravessava o auge da ditadura de Getúlio Vargas e o país mantinha muitos laços com a Alemanha, o que sugere que ele pode ter sofrido influências de outros intelectuais e do próprio período, um tanto conturbado e de tendência nacionalista. Na época, Freyre já se correspondia com Gustavo Barroso. 


\subsection{A ESCOLA DE FREYRE E SEUS DISCÍPULOS}

Conforme mencionado antes, Gilberto Freyre é um dos fundadores do Movimento Regionalista, iniciado nos primeiros anos da década de 20 , sendo seu marco oficial o $1^{\circ}$ Congresso Regionalista Brasileiro, realizado em fevereiro de 1926.

Com o surgimento da nova escola regionalista, muitos outros autores da região nordeste trilharam os caminhos abertos por Freyre, que soube com muita sagacidade comandar o barco e dar rumo ao movimento.

Mesmo após décadas do início do movimento regionalista, Freyre continuou inspirando seus pares. Um bom exemplo é Luís da Câmara Cascudo, um dos historiadores mais conhecidos do Brasil, contemporâneo de Freyre. "A receita popular pelo Nordeste, e a que tenho visto e provado no Rio de Janeiro, é a que Gilberto Freyre recolheu: - Pé de Moleque à Moda de Pernambuco: (...)" 82

Em sua História da Alimentação no Brasil, Câmara Cascudo parece mesmo fazer uma interlocução com Gilberto Freyre. As semelhanças com o Manifesto Regionalista denotam que não se trata de uma simples casualidade, e há trechos do livro de Câmara Cascudo, onde uma profusão de povos, hábitos alimentares, elementos da cultura e da história do Brasil se fundem para originar a cultura brasileira, seu povo e o país como um todo. Algo muito próximo do Manifesto Regionalista de Freyre e de outras obras como Casa Grande \& Senzala e Sobrados e Mucambos.

Sem esquecer de nenhum povo, de nenhuma cultura, vai expondo os hábitos e tradições de cada etnia. O que dizer deste pequeno parágrafo: "Os fogões de abóboda e da chapa, panelas, grelhas, frigideiras, de ferro, foram trazidos pelos portugueses, assim como talheres, cadeiras e mesas. Comer no chão era uso indígena e também oriental. Não sobre o solo nu, como faziam os ameríndios mas

\footnotetext{
${ }^{82}$ CASCUDO, Luís da Câmara Cascudo. História da Alimentação no Brasil. $2^{\circ}$ Vol. São Paulo, Cia. Editora Nacional, 1968. Pág. 270.
} 
com tapetes e alcatifas. Quando, por luto, alguém não assentava em esteira nem alcatife, era rito judaico, vedado ao cristão-velho." 83

Existem muitos trechos desta obra que dialogam com o Manifesto Regionalista, sendo impossível neste estudo traçar todos os paralelos e intertextualidades, mesmo porque História da Alimentação no Brasil é uma obra de fôlego, com mais de 500 páginas. Assim, selecionei apenas pequenos trechos que demonstram o fato de 0 autor ter bebido na mesma fonte de Freyre.

Como exemplo, o trecho a seguir, que Câmara Cascudo, parece ter extraído do Manifesto Regionalista. "Por isso, o que chamamos de feijoada é uma solução européia elaborada no Brasil. Técnica portuguesa com o material brasileiro." 84

Estes elementos presentes na obra de Câmara Cascudo indicam o quanto foi importante a obra de Freyre e, mais que isto, que ela sobreviveu ao tempo e ainda hoje é considerada pelo seu ineditismo e também pelo fato de atualmente ser uma das maiores fontes de pesquisa nos campos sociólgico, histórico e também o literário.

Mas não foi apenas Câmara Cascudo que sofreu influências diretas de Gilberto Freyre, outros autores também foram marcados pela literatura freyriana como: José Lins do Rêgo, Ascenso Ferreira, Olívio Montenegro, Sílvio Rabelo, Estevão Pinto, Ademar Vidal, Osíris Coutinho, Danilo Lobo, Munuel Diégues Junior, Ruy Coutinho, Luiz Jardim e tantos outros.

O que ilustra bem este fato é uma observação levantada por um destes autores, Luiz Jardim, que reforça a ação propagadora de Freyre: "Antes não tínhamos, rigorosamente (pelo menos aqui em Pernambuco), o sentido cultural brasileiro. Quero dizer, o sentido que nos devia dar um amplo conhecimento de nós mesmos (...) Foi sem dúvida graças à sua sensibilidade aguçada pelos estudos e pelas viagens, que tivemos tão desenvolvido o senso das nossas tradições de cultura (...) o interesse pelos solares, casarões, sobrados, de arquitetura colonial; o gosto da

\footnotetext{
${ }^{83}$ CASCUDO, Luís da Câmara Cascudo. História da Alimentação no Brasil. $2^{\circ}$ Vol. São Paulo, Cia. Editora Nacional, 1968. Pág. 80 - Informações que o autor extraiu da obra Primeira Visitação do Santo Officio às partes do Brasil, inserindo em seu livro.

${ }^{84}$ CASCUDO, Luís da Câmara Cascudo. História da Alimentação no Brasil. $2^{\circ}$ Vol. São Paulo, Cia. Editora Nacional, 1968. Pág. 108.
} 
fruta, do bolo, do doce, do quitute do norte; a sensibilidade ao colorido e ao mesmo tempo ao langor dos trópicos." 85

Manuel Diégues Junior foi outro autor que, com obras publicadas em período posterior, segue como um continuador da obra de Freyre, utilizando-se muito da obra freyriana em seus livros.

"Da contribuição judaica no Brasil vale destacar aquela já citada por Solidônio Leite: o preparo do ferro laminado, a chamada fôlha-de-flandres. Descoberta de um judeu brasileiro das Minas Gerais, prêso pela Inquisição, a técnica do preparo foi transmitida por aquêle a um companheiro de cela, em Lisboa; êste, quando libertado, a levou para Bruges, de onde se expandiu." 86

Na obra Etnias e Culturas no Brasil, Diégues Junior faz um levantamento de todas as etnias que contribuíram de alguma maneira para a formação do Brasil, havendo capítulos específicos para negros, índios, italianos, japoneses, alemães, árabes, poloneses, judeus e outros mais. Tudo descrito com muita proximidade a Gilberto Freyre, especialmente quando se compara com o livro O Mundo que o Português Criou, além, é claro, de utilizar-se das mesmas fontes de pesquisa (como por exemplo o livro Os Judeus no Brasil, escrito por Solidônio Leite em 1923), como no exemplo citado no parágrafo anterior.

\footnotetext{
${ }^{85}$ CASTELLO, José Aderaldo. José Lins do Rêgo: Modernismo e Regionalismo. São Paulo, EDART, 1961. Pág. 34 ( citação que Castello estraiu do Prefácio do livro Artigos de Jornal de G. Freyre e prefaciado por Luís Jardim).

${ }^{86}$ JUNIOR, Manuel Diégues. Etnias e culturas no Brasil. 4 ed. Rio de janeiro, Paralelo, 1972. Pág. 127.
} 


\section{0 - CONSIDERAÇÕES FINAIS}

Diante de tudo que foi pesquisado e catalogado, foram fichados noventa livros, de onde pode-se extrair algumas conclusões sobre a literatura brasileira, sobre Gilberto Freyre e também é possível traçar um pequeno panorama sobre a presença judaica no Brasil ao longo de mais de 500 anos, a partir da ótica oferecida pela literatura ficcional e do ensaio histórico-sociológico.

Com relação à literatura, é possível observar claramente o impulso que recebeu com a chegada do século XX, sobretudo após a década de 20 , quando esta muda de formato, o gênero poesia é paulatinamente substituído pela prosa, novos tipos e personagens vão povoando estas novas obras, o volume de obras publicadas cresce vertiginosamente, o número de leitores aumenta significativamente e, aos poucos, a cultura brasileira vai conquistando seu espaço (substituindo o lugar que antes era ocupado por culturas estrangeiras, especialmente a francesa).

Até a década de 20, a presença feminina ainda era muito fraca na literatura: . dos livros que foram estudados, encontramos apenas duas autoras, Julia Lopes de Almeida e Rosalina Coelho Lisboa. Após a eclosão do movimento modernista é que a mulher vai, pouco a pouco, conquistando seu lugar como literata e, nas décadas seguintes, aparecem nomes como o de Rachel de Queiroz, Clarice Lispectore Patrícia Galvão, entre outras.

Na maioria das obras que antecederam o Modernismo, percebe-se o quanto o Brasil rendia tributos às culturas estrangeiras, especialmente à cultura francesa, muitos autores inserindo citações em francês e elogiando seus pares franceses, sem falar no grande número de palavras francesas introduzidas nos livros e galicismos (muitos permanecem até os dias de hoje).

Com o surgimento do Modernismo, aparece uma nova faceta da cultura brasileira: não é apenas um modismo ou uma nova escola, mas sim um possível reflexo do nacionalismo escancarado que tomara conta de parte da elite cultural/política do 
país, que buscava lastreamento no passado para poder construir o presente e um possível futuro.

O mesmo nacionalismo que valorizava e glorificava a cultura nacional também menosprezava as culturas estrangeiras e outros povos, mascarando a questão da imigração, algumas vezes proibindo totalmente, em outras estabelecendo cotas a entrada de negros, japoneses, judeus e outros povos, considerados "não brancos", no país.

A política de imigração desde os tempos imperiais proibia a entrada de negros no país. Havia uma clara intenção dos governantes de branquear o Brasil. "Desde os princípios do século $\mathrm{XX}$, as autoridades federais brasileiras mantinham-se como controladoras dos surtos imigratórios e de povoamento com o objetivo de evitar conflitos verticais." 87

Ainda na época de D. Pedro II, nos idos do século XIX, o país recebeu com toda pompa e circunstância o Conde de Gobineau, conhecido por seu Ensaio sobre a desigualdade das raças, uma das mais famosas teses racistas. "A sincera amizade que lhe demonstrou o imperador não bastou para que o irascível diplomata reconsiderasse suas opiniões negativas sobre o Brasil." 88

Gobineau poupou apenas o imperador e sua família. Para o Conde, um dos males do país era a quantidade de negros e mestiços que deixavam os brasileiros indolentes. Assim mesmo, Gobineau foi uma das fontes de inspiração para muitos nacionalistas que estiveram à frente de órgãos governamentais que regulavam a imigração e também para chefes de estado, possuindo muitos adeptos tanto aqui no Brasil, como na Europa.

O ensaio do Conde de Gobineau pode ter sido a inspiração para as políticas imigratórias que foram adotadas pelo Brasil até o final da $2^{\mathrm{a}}$ Guerra Mundial. Mais brandas no tempo do Império, foram aos poucos sendo modificadas e cada vez mais impediam a entrada de imigrantes "considerados indesejados" pelo Estado.

\footnotetext{
${ }^{87}$ WALDMAN, Berta. Entre passos e rastros: presença judaica na literatura brasileira contemporânea. São Paulo, Perspectiva, 2003. Pág. XVI (Introdução)

${ }^{88}$ RAEDERS, Georges. O Conde de Gobineau no Brasil. Tradução Rosa Freire D’Aguiar. Rio de Janeiro, Paz e Terra, 1996. Pág. 7
} 
Tudo isto contado pela literatura, de uma forma mais clara, através de Gilberto Freyre, Solidônio Leite Filho, Roquette Pinto, Arthur Ramos, Eduardo Prado e tantos outros que buscaram as origens do Brasil e do povo brasileiro. Ou mesmo em obras ficcionais, como por exemplo A Marquesa de Santos, de Paulo Setúbal, publicada em 1924. Nela, o autor expressa uma das questões raciais do Brasil ao inserir a seguinte frase: "gente de sangue limpo, com larga parentela na cidade (...) " 89

Este pequeno fragmento sugere, por exemplo, o quanto a questão racial poderia importar para algumas pessoas, sobretudo para uma pequena elite cultural/política que ascendia ao poder e assaltaria a democracia uma década mais tarde.

Não que isto se refletisse na sociedade como um todo, pois no meio do povo a situação do imigrante era bem diferente, especialmente em cidades que receberam grandes levas imigratórias. "No século XIX, com a política de imigração, aportaram aqui novos contigentes culturais, que se foram mesclando à tradição trissecular, em processo dinâmico e renovador da cultura brasileira." 90

São Paulo na década de 20, por exemplo, era constituída em sua maioria por imigrantes, nacionais e não nacionais, das mais diversas origens; bairros quase que inteiros formados por italianos, espanhóis, portugueses, árabes, judeus, japoneses e outros, o que demonstra a enorme distância entre a política do estado brasileiro e seu povo.

Este mesmo governo nacionalista e anti-semita que, a partir de 1937, passa a mascarar a proibição da entrada no país de imigrantes judeus, não conseguia aplicar normas que restringissem a permanência destes mesmos imigrantes no país, pois independente da origem e/ou religião, o imigrante que entrava no país se integrava à sociedade brasileira, não havendo distinção entre este ou aquele estrangeiro. Quanto mais ascendia, maior era sua integração e sua visibilidade social.

Um exemplo significativo é o da escritora Clarice Lispector, nascida na Ucrânia, em uma família judia, que chegou ao Brasil no colo dos pais (a família Lispector é mais uma, das muitas famílias judias, que faz parte do fluxo migratório e que fugia dos pogroms na Rússia Czarista). Ela cresceu e estudou no Brasil e, já adulta, trabalhou

\footnotetext{
${ }^{89}$ SETUBAL, Paulo. A Marquesa de Santos. São Paulo, Cia. Editora Nacional, $3^{\mathrm{a}}$ ed., 1928. Pág. 7

${ }^{90}$ LUCAS, Fábio. Expressões da Identidade Brasileira. São Paulo, Educ, 2002. Pág. 150 e 151.
} 
como redatora na Agência Nacional, por volta de 1940. "É importante lembrar que ela se fixa nesse emprego durante o Estado Novo, tendo esse órgão oficial de informação sido criado por Getúlio Vargas, em 1934, subordinado ao Ministério da Justiça e Negócios Interiores. Ele será o futuro Departamento de Imprensa e Propaganda (DIP), subordinado diretamente à Presidência da República." 91

Assim, não podemos dizer que no Brasil, os judeus foram mais perseguidos que outros grupos de imigrantes, mas, ao contrário, é possível até mesmo afirmar que imigrantes judeus foram naturalmente incorporados à sociedade brasileira, como os demais grupos de imigrantes.

No próprio levantamento de obras do período, foram encontrados livros que defendiam a comunidade judaica como um todo, sendo contrários às ideologias nacionalistas tão em voga naquela época.

Alguns exemplos podemos ter ao ler o livro Os Judeus na Alemanha: no momento actual, escrito por Marcio Campos Lima, em 1933 (ver ficha n 072 do anexo III), e Por que ser anti-semita? um inquérito entre intellectuais brasileiros, também escrito em 1933 (ambos foram encontrados no acervo do Centro de Estudos Judaicos da USP). Com relação a este último, consegui localizar uma fonte primária, a propaganda da editora Civilização Brasileira anunciando o seu lançamento (ver ficha $\mathrm{n}^{\circ} 70$ do anexo III). Esta propaganda posteriormente foi encaminhada ao Arquivo Histórico Judaico Brasileiro para ser integrada ao acervo.

Há, inclusive, alguns estudiosos do tema que afirmam categoricamente que os judeus permaneceram em condições superiores: "Outro ponto que contribui para sustentarmos que no Brasil ser judeu é um trunfo é derivado - conforme foi ressaltado por grande gama de autores - da particularidade de sermos uma sociedade marcada pela abolição tardia da escravidão negra, onde, quanto mais um indivíduo se distingue de uma possível identidade negra, mais é valorizado na esfera do mercado de trabalho, das relações sociais, etc.(...) Nessa trama, ser judeu diz

\footnotetext{
${ }^{91}$ WALDMAN, Berta. Entre passos e rastros: presença judaica na literatura brasileira contemporânea. São Paulo, Perspectiva, 2003. Pág. XXV (Introdução)
} 
respeito a uma ascendência totalmente européia, significando inapelavelmente um não-ser-negro." 92

Os personagens estrangeiros aparecem pouco na literatura do período e quase sempre em papéis secundários e de pouca relevância, muitas das vezes caracterizados de forma estereotipada, como os personagens do livro Novelas Paulistanas, que reúne os livros de António de Alcântara Machado (ver ficha $\mathrm{n}^{\circ} 01$ do anexo III). Com relação ao personagem judeu, este aparece em número, ainda mais, reduzido, o exemplo mais significativo é aquele encontrado no livro Memórias; $1^{a}$ parte 1886-1900, de Humberto de Campos (ver ficha $\mathrm{n}^{\circ} 02$ do anexo III).

As referências encontradas à cultura judaica estão em geral associadas à religião, a elementos e/ou personagens do período bíblico. Algumas personalidades internacionais e oriundas da comunidade judaica aparecem com certa freqüência em crônicas e livros confeccionados a partir de textos publicados em periódicos. Entre elas, destaco o Barão Rothschild, Albert Eistein, Dreyfus, Espinosa, entre outros.

Quanto a Gilberto Freyre, podemos inferir que seu mérito foi resgatar o judeu como um dos personagens na formação do Brasil e de seu povo. Freyre foi um dos primeiros autores brasileiros a reconhecer a importância e o papel da comunidade judaica, tanto na formação do povo português, quanto na colonização e formação da população brasileira e no legado judaico que permanece nos hábitos e costumes do Brasil, especialmente no nordeste brasileiro, uma região que recebeu muitos judeus até a metade do século XVII.

Antes dele, Solidônio Leite Filho já havia publicado, em 1923, uma obra de reconhecido valor, denominada Os Judeus no Brasil. Apesar de sua importância e do próprio Freyre se utilizar da obra deste último em seus estudos, Gilberto Freyre conseguiu maior projeção, tanto no Brasil como no exterior.

Além disto, não se pode deixar de mencionar a importância de Gilberto Freyre na sociologia, antropologia, história e também na moderna literatura brasileira. A originalidade de sua obra ajudou a renovar os estudos sobre o Brasil e o povo

\footnotetext{
92 GRÜN, Roberto. Construindo um lugar ao sol: os judeus no Brasil. In Fazer a América: a imigração em massa para a América Latina. Org. Bóris Fausto. São Paulo, EDUSP, 1999. Pág. 370 e 371.
} 
brasileiro, revendo o papel do negro, das populações rurais, da imigração em geral e do contato de diferentes culturas que aqui se encontraram.

No caráter abrangido por esta pesquisa, não podemos destacar apenas os pontos positivos de sua obra, sendo necessário apontar a dualidade existente em seus textos e as contradições suscitadas, principalmente quando se lê Casa Grande \& Senzala ou Sobrados e Mucambos, mesmo porque muitas das denominações e termos utilizados em sua obra hoje seriam considerados politicamente incorretos ou, no mínimo, de cunho racista, mas o que devemos levar em conta é que Freyre constantemente utilizava como fonte para seus textos, jornais de época e estudos elaborados que refletiam uma realidade anterior; pois buscava no passado explicações para o futuro. Muito do que foi reproduzido em seus livros eram citações ou evocações de outros autores e estudiosos.

Suas posições políticas também contribuíram e interferiram nas leituras feitas de sua obra. Seus críticos não lhe pouparam hostilidades, dificultando a análise e o reconhecimento do valor de seu trabalho. Quem for ler Freyre, portanto, deve ter um olhar crítico, aproveitar a riqueza de informações que sua obra oferece e talvez relativizar as ideologias que surgem nas entrelinhas.

Assim como seus contemporâneos, Gilberto Freyre também sofreu influências da Semana de 22 e do movimento modernista. A distância geográfica, a sua formação diferenciada e as influências regionais fizeram com que o autor modificasse os ecos modernistas que chegaram ao Recife, sendo flagrante o tom memorialista impingido por Freyre, em que o conceito de cultura vai aos poucos substituindo o de raça, uma clara influência de seu mestre Franz Boas.

Gilberto Freyre está inserido no primeiro período modernista (1922 a 1945), e o crítico Antônio Cândido comenta: "Ao lado da ficção, o ensaio histórico-sociológico é o desenvolvimento mais interessante do período. A obra de Gilberto Freyre assinala a expressão, neste terreno, das mesmas tendências do Modernismo, a que deu por assim dizer coroamento sistemático, ao estudar com livre fantasia o papel do negro, 
do índio e do colonizador na formação de uma sociedade ajustada às condições do meio tropical e da economia latifundiária (...)" 93

Freyre procura encontrar no passado explicações que ajudem a entender o Brasil contemporâneo, seu povo, suas tradições e culturas, estando a questão antropológica nitidamente ancorada na antropologia norte-americana do início do século passado, uma conseqüência clara de sua formação.

Fica marcado, dessa maneira, o fato de o Manifesto Regionalista, sua primeira obra dentro do período estudado, resgatar o papel do judeu e de sua cultura na formação do povo e da cultura brasileira, até então ausentes da historia oficial, além de ser um documento muito importante, por inaugurar um movimento literário brasileiro, prenunciando o que viria a ser publicado pelo autor, posteriormente, em Casa Grande \& Senzala e Sobrados e Mucambos, entre outras obras de grande relevância no cenário nacional e internacional.

Também podemos inferir que Freyre influenciou outros autores e ensaístas, que repercutiram os ecos de sua obra e alteraram significativamente os rumos e os estudos sobre a origem e formação do povo brasileiro. Entre eles, podemos destacar Manuel Diégues Júnior e Câmara Cascudo, eminentes autores que publicaram livros lastreados na obra de Gilberto Freyre.

A pesquisa e o levantamento de obras, onde são identificados traços da cultura e religião judaicas, comparando com outras culturas estrangeiras presentes nos livros, como o estudo mais detalhado da obra de Gilberto Freyre, de onde são resgatados elementos importantes sobre a presença judaica no país, são elementos que compõem o universo literário brasileiro e por conseqüência a cultura brasileira. Desta forma, espero que esta pesquisa tenha conseguido contribuir, de alguma forma, para alargar as fronteiras dos estudos judaicos e o reconhecimento do papel do judeu na formação e construção do povo brasileiro.

\footnotetext{
${ }^{93}$ CANDIDO, Antônio. Literatura e Sociedade. São Paulo, Cia. Editora Nacional, 1976. Pág. 124.
} 


\section{1- BIBLIOGRAFIA}

- ANDRADE, Manoel Correia de. O espaço geográfico na obra de Gilberto Freyre. In Gilberto Freyre em quatro tempos. Organização: Ethel Volfzon Kosminsky, Claude Lépine, Fernanda Arêas Peixoto. Bauru, Edusc, 2003.

- $\quad$ ARENDT, Hanna. O Sistema Totalitário. Lisboa, Publicações Dom Quixote, 1978;

- CANDIDO, Antonio. Literatura e Sociedade. São Paulo, Cia. Editora Nacional, 1976.

- CANDIDO, Antonio, J. Aderaldo Castello. Presença da Literatura Brasileira história e antologia: I das origens ao realismo. São Paulo, Difel, 1987.

- CANDIDO, Antonio. "A Personagem do Romance", in A Personagem de Ficção. São Paulo, Perspectiva, 2000.

- CARNEIRO, Maria Luiza Tucci. O Discurso da Intolerância - fontes para estudo do racismo. São Paulo, 1996.

- CASCUDO, Luís da Câmara. História da Alimentação no Brasil - $2^{\circ}$ volume. São Paulo, Cia. Editora Nacional. 1968.

- CAStello, José Aderaldo. José Lins do Rêgo: Modernismo e Regionalismo. São Paulo, EDART, 1961.

- CHAUÍ, Marilena de Souza. O que é ideologia. São Paulo, Brasiliense, 1984.

- CHAVES, Flávio Loureiro. História e Literatura, Porto Alegre, UFRGS, 1999.

- DUARTE, Dina. Rota de Passagem: Historiadores restauram sinagoga dos judeus recifenses que ajudaram a fundar Nova York, in Revista Veja 07/04/1999.

- EBAN, Abba. A História do Povo de Israel. Tradução Alexandre Lissovsky. Rio de Janeiro, Bloch Editores, 1975. 
- FARIA, João Roberto. Idéias Teatrais - o século XIX no Brasil. São Paulo, Perspectiva, 2001.

- FAUSTO, Boris. Negócios e Ócios - história da imigração. São Paulo, Cia. das Letras, 1997.

- FAUSTO, Bóris. Construindo um lugar ao sol: os judeus no Brasil. In Fazer a América: a imigração em massa para a América Latina. São Paulo, EDUSP, 1999.

- FONSECA, Edson Nery. in Gilberto Freyre em quatro tempos/organização Ethel Volfzon Kominsky, Claude Lépine, Fernanda Arêas Peixoto. Bauru, EDUSC, 2003.

- FREYRE, Fernando de Mello. in Gilberto Freyre em quatro tempos/organização Ethel Volfzon Kominsky, Claude Lépine, Fernanda Arêas Peixoto. Bauru, EDUSC, 2003.

- FREYRE, Gilberto. O Velho Félix e suas memórias de um Cavalcanti. Rio de Janeiro, José Olympio, 1959.

- FREYRE, Gilberto. Olinda - $2^{\circ}$ guia prático, histórico e sentimental de cidade brasileira. $3^{a}$ Edição. Rio de Janeiro, José Olympio, 1960.

- FREYRE, Gilberto. Guia prático, histórico e sentimental da cidade do Recife. $4^{\mathrm{a}}$ Edição. Rio de Janeiro, José Olympio, 1968.

- FREYRE, Gilberto. Sobrados e Mucambos. 4a ed. Rio de Janeiro, José Olympio. 1968.

- FREYRE, Gilberto. Vida social no Brasil nos meados do século XIX; tradução Waldemar Valente. $2^{\mathrm{a}}$ ed. Rio de Janeiro, Artenova, 1977.

- FREYRE, Gilberto. Casa Grande \& Senzala. 34a ed. Rio de Janeiro, Record, 1992.

- FREYRE, Gilberto de Mello. Manifesto Regionalista. Organização e apresentação de Fátima Quintas. 7ª ed. Recife, FUNDAJ, Ed. Massangana, 1996. 
- FREYRE, Gilberto de Mello. Interpretações do Brasil: aspectos da formação social brasileira como processo de amalgamento de raças e culturas; tradução Olívio Montenegro. São Paulo, Cia. das Letras, 2001.

- GOMES, Alfredo de Freitas Dias. O Santo Inquérito. Rio de Janeiro, Ediouro, s.d.

- GRÜN, Roberto. Construindo um lugar ao sol: os judeus no Brasil. In Fazer a América: a imigração em massa para a América Latina. Org. Bóris Fausto. São Paulo, EDUSP, 1999.

- HERCULANO, Alexandre. História da origem e estabelecimento da inquisição em Portugal. Tomo I - Livro I - 1ª edição 1852 - Campinas, IFCH/UNICAMP n 43, 2001.

- INTERNAN, Alan. Dicionário Judaico de Lendas e Tradições. Rio de Janeiro, Jorge Zahar Editores, 1992.

- JUNIOR, Manuel Diégues. Etnias e culturas no Brasil. Rio de Janeiro, Ministério da Educação e Cultura, 1952.

- JUNIOR, Manuel Diégues. Etnias e culturas no Brasil. 4 ed. Rio de janeiro, Paralelo, 1972.

- KAYSERLING, M. Isaac Aboab, "The First Jewish Author in America", in American Jewish Hisorical Society, volume V. Nova Iorque, 1897.

- LAMM, Maurice. Bem vindo ao judaísmo: retorno e conversão. Tradução Dagoberto Mensch. São Paulo, Sêfer, 1999.

- LESSER, Jeffrey. O Brasil e a questão judaica: imigração, diplomacia e preconceito. Tradução Marisa Sanematsu. Rio de Janeiro, Imago, 1995.

- LESSER, Jeffrey. O judeu é o turco da prestação: etnicidade, assimilação e imagens das elites sobre árabes e judeus no Brasil. Estudos Afro-Aiáticos (Rio de Janeiro), v27, abril, 1995.

- LESSER, Jeffrey.A Negociação da Identidade Nacional: imigrantes, minorias e a luta pela etnicidade no Brasil. São Paulo, UNESP, 2000. 
- LIPINER, Elias. Gapar da Gama: um converso na frota de Cabral. Rio de Janeiro, Nova Fronteira, 1987.

- $\quad$ LUCAS, Fábio. Expressões da identidade brasileira. São Paulo, Educ, 2002.

- MACHADO, António de Alcântara. Novelas Paulistanas. Rio de Janeiro, Ediouro, 1999.

- MOISÉS, Massaud. Guia Prático de Análise Literária. São Paulo, Cultrix, 1970.

- MOISÉS, Massaud. História da Literatura Brasileira - origens, barroco, arcadismo. São Paulo, Cultrix, 1985.

- MOTTA, Rodrigo Patto Sá. O mito da conspiração judaico comunista. In Revista de História, número 138, São Paulo, Humanitas, 1998.

- NICOLA, José de. Literatura Brasileira - das origens aos nossos dias. São Paulo, Scipione, 1999.

- NOVINSKY, Anita. Cristãos Novos na Bahia: a inquisição. São Paulo, Perspectiva, 1970.

- NOVINSKY, Anita. Inquisição: prisioneiros do Brasil - séculos XVI - XIX. são Paulo, Expressão Cultural, 2001.

- RAEDERS, Georges. O Conde de Gobineau no Brasil. Tradução Rosa Freire D’Aguiar. Rio de Janeiro, Paz e Terra, 1996.

- ROANI, Gerson. Literatura e judaísmo: o rosto judeu de Borges. Porto Alegre, UFRGS, 2003.

- SCHILLING, Voltaire. O nazismo: breve história ilustrada. Porto Alegre, UFRGS, 1995.

- SETUBAL, Paulo. A Marquesa de Santos. São Paulo, Cia. Editora Nacional, $3^{a}$ ed., 1928.

- SKIDMORE, Thomas. in Gilberto Freyre em quatro tempos/organização Ethel Volfzon Kominsky, Claude Lépine, Fernanda Arêas Peixoto. Bauru, EDUSC, 2003. 
- SOARES, Teixeira. Machado de Assis(ensaio e interpretação), Rio de Janeiro, Typ. Guido \& Cia., 1936.

- VARNHAGE, F. A. Os Holandeses no Brasil. Salvador, Editora Progresso, 1955.

- WALDMAN, Berta. Entre passos e rastros: presença judaica na literatura brasileira contenporânea. São Paulo, Perspectiva, 2003. 


\section{2 - ANEXOS}

Os anexos são compostos de:

- Anexos I - ficha de leitura - página 96;

- Anexos II - levantamento bibliográfico - página 98;

- Anexos III - fichamento das obras que foram lidas - página 151. 
UNIVERSIDADE DE SÃO PAULO

FFLCH

DEPARTAMENTO DE LETRAS ORIENTAIS

ANEXO I - FICHA DE LEITURA 
AUTOR:

TÍTULO DA OBRA:

EDIÇÃO:

LOCAL DE PUBLICAÇÃO:

EDITORA:

DATA:

PROSA ( ) POESIA ( )

PERSONAGEM: JUDIA（） ESTRANGEIRA（）

REFERÊNCIAS: A PERSONAGENS OU PESSOAS JUDIAS ( )

A PERSONAGENS OU PESSOAS ESTRANGEIRAS ( )

REFERÊNCIAS: A CULTURA JUDAICA ( )

A CULTURA ESTRANGEIRA（）

REFERÊNCIAS: INTERTEXTUAIS（） TEXTUAIS（）

SE SIM, QUAIS?

CARACTERÍSTICAS DA PERSONAGEM JUDIA:

- NOME:

- CARACTERÍSTICAS FÍSICAS:

\section{A REFERÊNCIA APARECE:}

- CAPÍtULO(s)

- PÁGINA(s)

- PARÁGRAFO(S)

OBSERVAÇÕES ESPECÍFICAS: 
ANEXO II - LEVANTAMENTO BIBLIOGRÁFICO 


\section{Pesquisa bibliográfica período: 1900 - 1945}

Base selecionada: Livros e Outros Materiais - Biblioteca Central FFLCH/Dedalus BUSCA: Ano = AAAA

Ano

Autor. Título

Localização nas bibliotecas da USP

\section{0}

Marques, Xavier. Holocausto

Ed. Garnier Rio de Janeiro

\section{1}

Goulart, Arthur. Dez contos

FD DBC/Q1-27-38

Azevedo, João Lúcio de. Os Jesuítas no Grão-Pará: suas missões e a colonização FD DBC/S12-35-2

Azevedo, Arthur. Contos fora de moda

FFLCH-LE/869.934S^AZ986

Veríssimo, José. Estudos de literatura brasileira

FFLCH-LE/869.909^V619

Menezes, Rodrigo Cesar de. Publicação official de documentos interessantes para a história e costumes de São Paulo

FD DBC/R4-14-8^V12-3

Pennafort, Ulysses de. Mandu (o eremicola) romance indo-brazileiro IEB/MA869.9349^P397m

Melo, Pedro Américo de Figueiredo e. Na cidade eterna

IEB/YAN^869.9349^F4757m^ex.1

Aranha, Graça. Chanaan

IEB/ 869.9348^A662C

Bessa, Alberto. A gíria portugueza

IEB $469.7^{\wedge} \mathrm{C} 329 \mathrm{~g}$.

Barreto, Tobias. Polêmicas (obra póstuma publicada por Sylvio Romero)

FFLCH-LE/869.^M543 


\section{2}

Prado, Eduardo. Viagens

FFLCH-GE/57^P869v^1902

Azevedo, Carlos Magalhães de. Homens e livros

FFLCH-LE/869.945^A985h

Magalhães, Couto de. Viagem ao Araguaya

FFLCH-GE/918.17^M188v

Veríssimo, José. Homenas e cousas estrangeiras

FFLCH-LE/869.9447^V619ho

Araújo, Murillo. lluminação da vida

FFLCH-LE/869.915^A69i

Azevedo, Aluísio de. A condessa Vésper

FFLCH-LE/obra esp.^00400

Almeida, Sílvio de. O antigo vernáculo

FFLCH-LE/obra esp.^00370

Carvalho, Aderbal. Esboços literários (fala sobre arianísmo)

FFLCH-LE/869.909^C321e

\section{3}

Barreto, Tobias 1839-1889 Dias e noites publicação posthuma Tobias Barreto ; dirigida por Sylvio Roméro

FFLCH-LE /869.9142^B264d^1903

Costa, Claudio Manuel da Obras poeticas de claudio manuel da costa (glauceste saturnio)

FFLCH-LE /869.9122^C8710^v.1-2

Silva, Francisca Julia da 1874-1920 Esphinges versos

FFLCH-LE /869.9149^J89e

Azeredo, Carlos Magalhães de 1872-1963 Horas sagradas

FFLCH-LE /869.915^A985h

Brito, Raymundo de Farias Finalidade do mundo o mundo como actividade intellectual FFLCH-GE /101^B862f^1903

Oliveira Lima, Manuel. No Japão impressões da terra e da gente

FFLCH-GE /57:565^L732j^1903

Almeida, Clemente Alvares de Oliveira Mendes E Memorando sobre a independencia; extraido de publicacoes do arquivo nacional FFLCH-HI /981.03^A447m 
Távora, Franklin 1842-1888 Um casamento no arrabalde historia do tempo em estylo de casa por Franklin Távora

FFLCH-HI /CE^5085

Gonzaga da Silva Leme, Luiz 1852- Genealogia paulistana

FFLCH-GE /OBRA ESP.^00085^1903^v.1

Prado, Eduardo 1860-1901 A bandeira nacional

FFLCH-HI /981^P896b

Guimaraes, Jose de Freitas. Musa nova

FFLCH-LE /869.915^G978m

\section{4}

Marinho, Henrique. O theatro brasileiro (alguns apontamentos para a sua historia)

FFLCH-LE /869.9209^M29t

Souza Bandeira, João Carneiro de 1865-1917.Estudos e ensaios

FFLCH-LE /869.9448^B165es

Bilac,Olavo.Critica e fantasia (em minas - chronicas fluminenses - notas diarias - na academia)

FFLCH-LE /869.9845^B492C

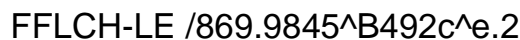

Vasconcellos, Diogo Luiz de Almeida Pereira de 1843-1927. Historia antiga das Minas Geraes FFLCH-HI /981.51^V331ha

Vasconcelos, Diogo de.Historia antiga das minas gerais. Diogo de Vasconcelos FFLCH-HI /981^V331h

\section{5}

Pessoa, Paula. Guia da cidade do rio de janeiro, 3. Congresso scientifico latino - americano

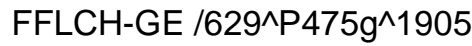

FFLCH-GE /OBRA ESP.^140

Botelho, Carlos. Relatorio apresentado ao dr. Jorge tibirica presidente do estado FFLCH-HI /981.61^B749r

Duarte, Raphael. Campinas de outr'ora

FFLCH-HI /981.6^D812C

Santos, Francisco Quirino dos. Estrellas errantes FFLCH-LE /869.915^S235e^3.ed

Verissimo, Jose. Homens e cousas estrangeiras, segunda serie 1901-1902 FFLCH-LE /OBRA ESP.^00534

Romero, Sílvio 1851-1914.Evolucao da litteratura brasileira (vista synthetica) FFLCH-LE /OBRA ESP.^00546 


\section{6}

Silveira, Álvaro A. da. Viagem pelo brasil notas e impressões colhidas na viagem do Sr. Dr. Affonso Penna, 12 de maio a 24 de agosto de 1906

FFLCH-FI /918.1^S587v

Bezerra, Antonio. Ceara e os cearenses, ligeiras apreciações

FFLCH-HI /981.31^B574c

Santos, Gomes dos. Uma caçada em balão

FFLCH-LE /028.5^Sg235c

Ribeiro, João 1860-1934.Paginas escolhidas

FFLCH-LE /869.9349^R369p^v.1

FFLCH-LE /869.9349^R369p^v.2

\section{7}

Pinto, Adolpho Augusto. Cartas da Europa.

FFLCH-HI /CE^4064

Goulart de Andrade, Jose Maria. Poesias 1900-1905

FFLCH-LE /869.9149^G727p

Redondo, Garcia. Salada de fructas

FFLCH-LE /869.9349^R252s

Cruz, Alcides. Epitome da guerra entre o Brasil e as Provincias Unidas do Rio da Prata

FFLCH-HI $/ 981.04^{\wedge} \mathrm{C} 955 \mathrm{e}$

Coelho Netto, Henrique 1864-1934. Theatro Pecas Em Um Acto

FFLCH-LE $/ 869.9247^{\wedge} \mathrm{C} 618 \mathrm{t}^{\wedge} \mathrm{V} .2$

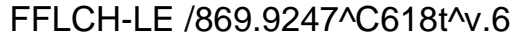

Xavier, Lindolfo. Flores e fructos

FFLCH-LE /869.9349^X21f

\section{8}

Carvalho, Vicente Augusto de 1866-1924.Poemas e canções

FFLCH-LE /869.9149^C329p^1908

Almeida, Júlia Lopes de 1862-1934. A intrusa

FFLCH-LE /869.935^Al448i

Figueiredo, Affonso Celso de Assis. Porque me ufano do meu paiz FFLCH-LE /869.9449^F488p^4 ed.

Silva, Antonio Francisco da Costa E. Sangue FFLCH-HI /CE^4794 


\section{9}

Dias, Gonçalves 1823-1864.Brasil e a oceania Antonio Goncalves Dias FFLCH-LE /869.9133^G625b

Romero, Sílvio 1851-1914.Compendio de historia da literatura brasileira FFLCH-LE /869.909^R672c

\section{0}

Amaral, Amadeu. Nevoa Amadeu Amaral

FFLCH-LE /869.915^A512n

Romero, Sílvio 1851-1914.Provocacoes e debates. (Contribuicoes para o estudo do brazil social) FFLCH-LE /869.945^R672p

Ornellas, Amaral. Illuminuras

FFLCH-LE /869.9149^081i

Goulart de Andrade, Jose Maria. Theatro, 2. Serie os inconfidentes (setembro a dezembro 1907) FFLCH-LE /869.9249^G727th

Azevedo, Arthur 1855-1908. Contos em verso Arthur Azevedo

FFLCH-LE /869.9345^Az986cv^1910

Coelho Netto, Henrique 1864-1934.Scenas e perfis

FFLCH-LE /869.9347^C618sc^e.1

Alencar, Mário de. Alguns escritos

FFLCH-LE /869.985^A354a

Ribeiro, João 1860-1934. O fabordão cronica de vario assunto FFLCH-LE /869.9394^R369fa

Araripe Junior, T A. Gregorio de matos guerra

FFLCH-LE /869.9711^M3911a

\section{1}

Perneta, Emiliano Davi. Illusao

FFLCH-LE /869.9149^P53li

Cruz, Delermando. Bernardo guimaraes perfil bio-biblio-literario

FFLCH-LE /869.9333^G9761C

Oliveira, Alberto de 1857-1937 ed.Paginas de ouro da poesia brasileira

FFLCH-LE /869.9146^O45pa^1911

Guimaraes, Jose de Freitas. Fuga das horas

FFLCH-LE /869.915^G976f 
Schmidt, Afonso. Janellas abertas

FFLCH-LE /869.915^S376j

\section{2}

Coelho Netto, Henrique 1864-1934. Banzo

FFLCH-LE /OBRA ESP.^Coelho

Coelho Netto, Henrique 1864-1934. Inverno em flor

FFLCH-LE /869.9347^C618f

Coelho Netto, Henrique 1864-1934. O morto memorias de um fuzilado

FFLCH-LE /869.9347^C618mor^2.ed

Maya, Alcides. Machado de Assis algumas notas sobre o humor

FFLCH-LE /869.9341^ex.1^m1291may

Garcia Redondo, Manuel Ferreira 1854-1916. Cara alegre (Paginas humoristicas)

FFLCH-LE /869.9849^R252C

Freitas, Leopoldo de. Esboço geral de literatura

FFLCH-LE /801^F936e

\section{3}

Tigre, Bastos 1882-1957.Moinhos de vento [por] D. Xiquote [pseud.] Com um prólogo de Coelho Netto]

FFLCH-LE /869.9149^T448m

Oliveira, Alberto de 1857-1937. Poesias, terceira serie 1904-1911

FFLCH-LE /869.9146^O45p

Durão, José de Santa Rita 1720 (ca.)-1784. Caramurú poema epico do descobrimento da Bahia FFLCH-LE /869.9121^S222c^1913

Almeida, Júlia Lopes de 1862-1934. Correio da roça

FFLCH-LE /869.935^Al448c

Coelho Netto, Henrique 1864-1934.Contos escolhidos

FFLCH-LE /869.9347^C618c

Bilac, Olavo 1865-1918.Poesia

FFLCH-LE /869.9148^B492p^5.ed

Thesouro poetico brasileiro collectanea das melhores poesias nacionaes, 1750-1900 Osorio Duque-Estrada

FFLCH-LE /869.9108^D949t

Oliveira, Alberto d' 1873-1940. Pombos-Correios (notas quotidianas)

FFLCH-LE /869.87^O45po 


\section{4}

Vieira, Antonio Antunes d. O poeta Santa Rita Durão revelações historicas da sua vida e do seu seculo Arthur Viegas

FFLCH-LE /869.9121^S2221v

Papi, Antonio 1865-1934. Gêmeos (romantização eclética) : velhos scenarios do Rio-de-Janeiro Papu Junior

FFLCH-LE /869.9349^P234g

Fernandes, Carlos D. 1875-1942. Os cangaceiros romance de costumes sertanejos

FFLCH-LE /OBRA ESP.^00420

Rangel, Alberto 1871-1945. Inferno verde scenas e scenarios do ; com um prefacio de Euclydes da Cunha

FFLCH-HI /CE^4313

\section{5}

Telles, Goffredo T da Silva. Mar da noite FFLCH-LE /869.9103^T275m

Almeida, Filinto de 1857-1945. Cantos e cantigas

FFLCH-LE /869.9145^A446c

Machado, Gilka da Costa Mello 1893-.Crystaes partidos

FFLCH-LE /869.915^M131C

Fleiuss, Max 1868-1943.A semana, 1893-95 chronica de saudades

FFLCH-LE /869.9849^F625s

Cearense, Catullo da Paixao. Florilegio dos cantores

FFLCH-LE /869.915^C38f

Silva, Laura Da Fonseca E. Poesia

FFLCH-LE /869.915^S581p

\section{6}

Veríssimo, José 1857-1916. Historia da literatura brasileira de Bento Teixeira, 1601 a Machado de Assis, 1908

FFLCH-LE /869.909^V619h^1916

Carvalho, Vicente de 1866-1924. Voz do sino

FFLCH-LE /869.9149^C329v

FFLCH-LE /869.9149^C329v^e.2

Teixeira, Mucio. Terra incognita

FFLCH-LE /869.9149^M267t

Bilac, Olavo 1865-1918.Ironia e piedade

FFLCH-LE /869.9845^B492i 
Paixao, Mucio da. Espirito alheio episodios e anedotas de gente de theatro

FFLCH-LE /869.9209^P172e

\section{7}

Barroso, Gustavo. Heroes e bandidos os cangaceiros do nordeste

FFLCH-LE /869.935^B285h

Amaral, Amadeu. Espumas versos

FFLCH-LE /869.915^A512e

FFLCH-LE $/ 869.915^{\wedge} A 512 \mathrm{e}^{\wedge} \mathrm{e} .2$

FFLCH-LE $/ 869.915^{\wedge} \mathrm{A} 512 \mathrm{e}^{\wedge} \mathrm{e} .3$

Pujol, Alfredo.Conferencias

FFLCH-LE /869.9341^M1291p^levi

Carvalho, Vicente de 1866-1924.Poemas e canções

FFLCH-LE /869.9149^C329p^3.ed

Pujol, Alfredo.Machado de Assis curso literario em sete conferencias na sociedade de cultura artistica de sao paulo

FFLCH-LE /869.9341^M1291p^brazil

Bandeira, Souza. Paginas literarias

FFLCH-LE /869.9448^B165p

Barroso, Gustavo. Ideas e palavras

FFLCH-LE /869.945^B285i

Bilac, Olavo 1865-1918. A defesa nacional (discursos)

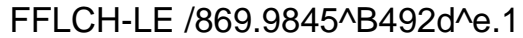

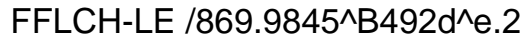

Menezes, Emílio de 1866-1918.Ultimas rimas

FFLCH-LE /869.915^M51u

Coelho, Jose Baptista. Caicaras

FFLCH-LE $/ 869.935^{\wedge} \mathrm{C} 614 \mathrm{c}^{\wedge} 2$.ed.

Franco, Affonso Arinos de Mello. Contractador dos diamantes

FFLCH-HI /CE^163

FFLCH-LE /869.92^F894C

Murat, Luiz. Poesias escolhidas

FFLCH-LE /869.9149^M947p

Lucio, Joao. Bom viver

FFLCH-LE /869.9349^L972b

\section{8}

Azevedo, J Eustachio de.Anthologia amazonica poetas paraenses

FFLCH-LE /869.9108^Aj987a^2.ed. 
Valle, Luiz Ribeiro Do. Psychologia morbida na obra de Machado de Assis

FFLCH-LE /869.9341^M1291/^2.ed^e.1

Sousa, Joao Alberto. Amadeu amaral urzes, nevoa, espumas...

FFLCH-LE /869.915^A5121s

Maciel, Julio Barbosa.Terra martyr

FFLCH-LE /869.9149^M138t

\section{9}

Salles, Antonio.Minha terra

FFLCH-LE /869.915^C162m

Cunha, Euclides da.Castro alves e seu tempo ; discurso proferido no centro academico 11 de agosto de sao paulo

FFLCH-LE /869.9145^C351ct

FFLCH-LE $/ 869.9145^{\wedge} \mathrm{C} 351 \mathrm{ct}^{\wedge} \mathrm{e} .2$

Bilac, Olavo 1865-1918.Tarde

FFLCH-LE /869.9148^B492t^ex.1

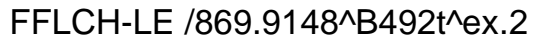

Guimaraes, Jose de Freitas.Olavo bilac

FFLCH-LE /869.9148^B4921g

Costa, Fernandes. Elogio academico de Olavo Bilac ..

FFLCH-LE /869.906^B4921c

Santos, Nestor Victor dos. A critica de hontem

FFLCH-LE /869.9449^V686c

Azeredo, Carlos Magalhaes de. Vida e sonho FFLCH-LE /869.915^A985v

Vieira, Celso 1878-. Endymiao dialogo e aspectos

FFLCH-LE /869.9449^V714e^2.ed

Vieira, Celso 1878-.Semeador

FFLCH-LE /869.9449^V714s

Edmundo, Luiz 1878-1961. Rosa dos ventos

FFLCH-LE /869.915^E26r

Marques, Xavier 1861-1942. A bôa madrasta

FFLCH-LE /869.9349^M317b

Menotti Del Picchia. Flamma e argila romance

FFLCH-LE /869.935^M517fl

Esteves, Lindolpho. Exilio

FFLCH-LE /869.9149^Е84e 


\section{0}

Vasconcelos, Carlos de. Cazados ... na America

FFLCH-LE /869.93^V45c

Almeida, Guilherme de 1890-1969.Livro das horas de soror dolorosa "a que morreu de amor"

FFLCH-LE /869.915^A447|^1920

Amaral, Amadeu. Soneto de bilac

FFLCH-LE /869.9148^B4921a^ex.1

Menotti del Picchia, Paulo 1892-.Mascaras

FFLCH-LE /869.915^M517m^1920

Albuquerque, Medeiros e 1867-1934. Marta

FFLCH-LE /869.9349^M438m

Coelho Neto, Henrique Maximiano 1864-1934.Mysterio

FFLCH-LE /869.9347^^618my

Bandeira, João Carneiro de Sousa 1865-1917. Evocaçåoes e outros escritos; com uma introd. de Mario de Alencar

FFLCH-LE /869.9448^B165e

Amaral, Amadeu 1875?-1929. Letras floridas ..

FFLCH-LE /869.945^A512/^1920^e.1

Peixoto, Afrânio 1876-1947. Parábolas

FFLCH-LE /869.985^P43pr

Lannes, Jose. Vana

FFLCH-LE /869.915^L279v

Silveira, Valdomiro 1870-1941.Os caboclos

FFLCH-FI /869^S587c

Lopes de Almeida, Julia 1862-1934.Jornadas no meu país

FFLCH-LE $/ 869.935^{\wedge} \mathrm{Al} 448 \mathrm{j}^{\wedge} \mathrm{e} .1$

Coutinho, Galeão. Parque antigo

FFLCH-LE /869.9149^C896p

Mello, Canto e. Reliquias da memória

FFLCH-LE /869.935^M477^^1920

\section{1}

Taunay, Alfredo d'Escragnolle Taunay Visconde de 1843-1899.Trechos de minha vida FFLCH-HI /CE^5081

Valle, Luiz Ribeiro do. Certos escriptores brasileiros psycho-pathologistas FFLCH-LE /869.909^V243ce 
Academia Brasileira de Letras. Castro alves apologia e critica Academia Brasileira de Letras FFLCH-LE /869.9145^C351re

Motta, Arthur 1879-. José de Alencar (o escriptor e o politico) sua vida e sua obra FFLCH-HI /CE^3677

FFLCH-LE /869.9334^A3531mot^e.1

Coelho Netto, Henrique 1864-1934. Sertão

FFLCH-LE /869.9347^C618s^4.ed^ex.1

Assis, Machado de 1839-1908.Machado de Assis [selecção] por Alberto de Oliveira e Jorge Jobim FFLCH-LE /869.9341^ex.1^m1291ol

Thiollier, Rene. Senhor dom torres paginas agrodoces

FFLCH-LE /869.935^T372s

Couto, Rui Ribeiro 1898-1963.O jardim das confidencias [poemas]

FFLCH-LE /869.985^R368j

Alves, Constancio. Figuras

FFLCH-LE $/ 869.9849^{\wedge} A 478 f^{\wedge} \mathrm{e} .1$

Obras completas de castro alves Castro Alves ; [Comp] Afranio Peixoto

FFLCH-LE /869.9145^C350^v.1

Magalhães, Carlos Fernando. Poesias

FFLCH-HI /869.915^B595p

Pires, Cornélio. Scenas e paizagens da minha terra (musa caipira)

FFLCH-FI /869^P667s

Schmidt, Afonso. Mocidade

FFLCH-LE /869.9149^S376^e.2.

Cascudo, Luis da Camara. Alma patricia critica litteraria FFLCH-LE /869.909^C331a

Taunay, Alfredo d'Escragnolle Taunay Visconde de 1843-1899.Philologia e crítica impressões e estudos

FFLCH-LE /869.9343^T223p

Taunay, Alfredo d'Escragnolle Taunay Visconde de 1843-1899.Viagens de outr'ora FFLCH-HI /869^T226vi

Torres, Antonio 1885-1934.Verdades indiscretas

FFLCH-LE /869.935^T643v^2.ed.

Lobato, José Bento Monteiro 1882-1948.A onda verde jornalismo

FFLCH-HI /CE^3614

Lisboa, Rosalina Coelho. Rito pagão

FFLCH-LE /869.915^L75r

Marques, Xavier; O sargento pedro FFLCH-LE /869.9349^M317s^2.ed. 
Sette, Mário 1886-1950.Senhora de engenho

FFLCH-LE /869.935^S519s^2.ed.

Peixoto, Afrânio 1876-1947. Maria Bonita

FFLCH-LE /869.935^P43m^4.ed

Taunay, Alfredo d'Escragnolle Taunay Visconde de 1843-1899.Cartas da campanha a cordilheira, agonia de López (1869-1870) Visconde de Taunay

FFLCH-LE /869.9343^T223ca

\section{2}

Taunay, Alfredo d'Escragnolle Taunay Visconde de 1843-1899.Visconde de Taunay por Alberto de Oliveira e Jorge Jobim

FFLCH-LE /869.9343^T22310^1922

Almeida, Guilherme de 1890-1969. Era uma vez versos de Guilherme de Almeida; desenhos de John Graz

FFLCH-LE /869.915^A447e

Peixoto, Afrânio 1876-1947.Castro Alves, o poeta e o poema FFLCH-LE /869.9145^C351p^1922

Carvalho, Ronald de 1893-1935. Epigrammas ironicos e sentimentaes

FFLCH-LE /869.915^C327e^2.ed

Magalhães de Azeredo, Carlos 1872-1963. Adriadne

FFLCH-LE /869.935^A985a

Almeida, Júlia Lopes de 1862-1934. A isca

FFLCH-LE /869.935^Al448i

Alencar, José Martiniano de 1829-1877. José de Alencar com uma introd. por Mario de Alencar FFLCH-LE /869.9334^A3531aL

Lima, Alceu Amoroso 1893-. Affonso Arinos [por] Tristão de Athayde [pseud.]

FFLCH-LE /869.9349^M4851I

Coelho Neto, Henrique Maximiano 1864-1934. Meu dia

FFLCH-LE /869.985^1922^ex.1^c618meu

Correia, Raymundo 1859-1911. Poesias

FFLCH-LE /869.9147^^C849p^^4.ed^ex.1

Menotti del Picchia, Paulo 1892-. Mulher que pecou

FFLCH-LE /869.935^M517m

Menotti del Picchia, Paulo 1892-. Homem e a morte tragedia cerebral

FFLCH-LE /869.935^M517h

Fontes, Hermes Floro Martins. Despertar canto brasileiro

FFLCH-LE /869.915^F766d

Taunay, Alfredo d'Escragnolle Taunay Visconde de 1843-1899. Innocencia

FFLCH-LE /869.9343^T223i^14.ed 
Marques, Xavier 1861-1942. O feiticeiro

FFLCH-LE /869.9349^M321f

Leitão da Cunha, José Maria Tristão 1878-. Cousas do tempo

FFLCH-LE /869.9449^C98c

Andrade, Nuno Ferreira de 1851-1922.Contos e chronicas Felicio Terra

FFLCH-HI /CE^5101

Taunay, Visconde de 1843-1899. Céos e terras do Brasil pelo Visconde de Taunay FFLCH-LE /869.9343^T223c

Correa, Viriato. Terra Santa Cruz

FFLCH-LE /869.935^C846t^2.ed.

Ramos, Hugo de Carvalho 1895-1921. Tropas e boiadas

FFLCH-LE /869.9349^R143t^2.ed.

Menegale, Heli. Azul

FFLCH-LE /869.915^M498a

Silva, João Pinto da. Physionomias de "novos"

FFLCH-HI /CE^4797

Carvalho, Elisio de. Os bastioes da nacionalidade

FFLCH-LE /869.945^C324b

Schmidt, Affonso. Brutalidade

FFLCH-LE /869.935^S376b

Theophilo, Rodolpho Marcos 1853-1932. O reino de Kiato (no Paiz da verdade)

FFLCH-LE /869.9349^T356r

FFLCH-LE /869.9349^T356r^e.2

Souza, Claudio de 1876-1954. Flôres de sombra comedia em 3 actos FFLCH-LE /869.925^S714f^4.ed.

Vasconcelos, Carlos de 1881-1923. Deserdados romance da Amazonia

FFLCH-LE /869.9349^V45d^2.ed.

Fontes, Martins 1884-1937. Arlequinada fantasia funambulesca mimo FFLCH-LE /869.9249^M343a

Corrêa, Francisco de Aquino 1885-1956.Terra natal [

FFLCH-HI /CE^1284^2.ed.

Fontes, Martins 1884-1937.0 mar

FFLCH-LE /869.9549^M343m

\section{3}

Madeiros e Albuquerque, José Joaquim de Campos da Costa 1867-1934.Teatro...meu e dos outros FFLCH-LE /869.9249^M438t 
Bilac, Olavo 1865-1918.Poesias

FFLCH-LE /869.9148^B492p^10.ed

Barros, Joao de. Olavo bilac e euclides da cunha

FFLCH-LE /869.9148^B4921b

Primeiras letras: Cantos de Anchieta, O dialogo de João de Léry, Trovas indígenas

FFLCH-LE /869.911^Pr95

Teixeira, Bento.Prosopopeia Bento Teixeira ; [Pref] Afranio Peixoto (?)

FFLCH-LE /869.9111^T264p^1923

FFLCH-LE /869.9111^T264p^1972

Cruz e Sousa, João da 1861-1898.Poesias broquéis, pharoes, ultimos sonetos Cruz e Souza ; com introducção e annotações de Nestor Victor

FFLCH-LE /869.9149^C964p

Carvalho, Ronald de 1893-1935. O espelho de Ariel

FFLCH-LE /869.915^C327es

Carvalho, Ronald de 1893-1935. Poemas e sonetos

FFLCH-LE /869.915^C327p^2.ed

Academia Brasileira de Letras. Primeiras letras

FFLCH-LE /869.908^A153p

Guerra, Alvaro. José de Alencar (sua vida e suas obras)

FFLCH-LE /869.9334^A3531gu

Aranha, Graça 1868-1931. Machado de Assis e Joaquim Nabuco commentários e notas à correspondência entre estes dous escriptores

FFLCH-LE /869.9648^G753m^e.1

Bello, José Maria. Margem dos livros

FFLCH-LE /869.945^B39m

FFLCH-LE /869.945^B39m^e.2

Campos, Humberto de 1886-1934. Carvalhos e roseiras (figuras politicas e literarias)

FFLCH-LE $/ 869.945^{\wedge} \mathrm{C} 212 \mathrm{c}$

Monteiro Lobato, José Bento. O macaco que se fez homem

FFLCH-LE /869.985^M778ma^1923

Matos Guerra, Gregorio de. Obras de gregorio de mattos lyrica

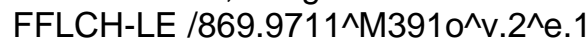

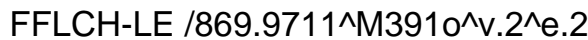

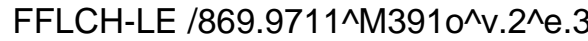

Cunha, Euclydes da 1866-1909.Os sertões (campanha de Canudos)

FFLCH-HI /869.3^C972s^6.ed.

Povina Cavalcanti, Carlos. O accendedor de lampeões

FFLCH-LE /869.904^C336a

Ribeiro, João 1860-1934. Colmeia(Segunda serie de - Notas de um estudante - do mesmo autor) 
FFLCH-LE /869.9394^R369co

Cunha, Euclydes da 1866-1909. Contrastes e confrontos

FFLCH-HI /CE^1380

FFLCH-LE /981^6. ed^^c9771co

Piza, Moacyr. Vespeira

FFLCH-LE /869.9149^P766v

Almeida, Fialho de. Figuras de destaque livro póstumo

FFLCH-HI /869^A447fi

FFLCH-LE /869.869^F464f^1923

Primeiras letras: Cantos de Anchieta, O dialogo de João de Léry, Trovas indígenas

FFLCH-HI /869^A539p

Coelho Netto, Henrique 1864-1934. Pastoral evangelho em 1 prólogo e 3 quadros

FFLCH-LE /869.9247^C618p^e.1

Calmon, Pedro. Pedra de armas contos

FFLCH-LE /869.935^C163p

Oliveira, Alberto de 1857-1937.Poesias terceira serie (1904-1911) nova edicao...

FFLCH-LE /869.9146^O45p^1923

Muniz, Souza. Folhas seccas

FFLCH-HI /CE^3696

Ambrogi, Cesidio. Poemas vermelhos uma tentativa de poesia social

FFLCH-LE /869.915^A529p

Grieco, Agrippino. Cacadores de symbolos

FFLCH-LE /801.95^G863c

\section{4}

Ribeiro Couto, Rui. Poemetos de ternura e de melancolia FFLCH-LE /869.915^R368p^1924

Abreu, Benedito Luis Rodrigues de. Sala dos passos perdidos

FFLCH-LE /869.915^A145s

Seixas, Aristeo. Por de sol FFLCH-LE /869.915^S464p

Silva, João Pinto da. Historia literaria do Rio Grande do Sul

FFLCH-LE /869.909^S58h

Cruz e Sousa, João da 1861-1898. Prosa missal, evocações Cruz e Souza ; com annotações de Nestor Victor

FFLCH-LE /869.9149^C964pm^ex.1

FFLCH-LE /869.9149^C964pm^ex.2 
Silveira Neto. Cruz e sousa

FFLCH-LE /869.9149^C9641s

Azevedo, Arthur 1855-1908. Contos ephemeros

FFLCH-LE /869.9345^Az986ce^4.ed^e.1

FFLCH-LE /869.9345^Az986ce^4.ed^e.2

Azeredo, Magalhães de b. 1872.Casos do amor e do instinto

FFLCH-LE /869.935^A985c

Coelho Netto, Henrique 1864-1934.Balladilhas

FFLCH-LE /869.9347^C618ba^3.ed

Coelho Netto, Henrique 1864-1934.Fabulario

FFLCH-LE /869.9347^C618fa^3.ed

Coelho Netto, Henrique 1864-1934.Misterio do Natal

FFLCH-LE /869.9347^C618mis

Coelho Netto, Henrique 1864-1934.0 morto (memorias de um fuzilado)

FFLCH-LE /869.9347^C618mo^3.ed

Coelho Netto, Henrique Maximiano. Sete dores de $\mathrm{n}$ senhora

FFLCH-LE $/ 869.9347^{\wedge}$ C618se^3.ed

Coelho Neto, Henrique Maximiano 1864-1934. Tormenta

FFLCH-LE /869.9347^C618to

Netto, Coelho 1864-1934. Treva

FFLCH-LE /869.9347^C618tr^e.1

FFLCH-LE /869.9347^^618tr^e.2

Menotti del Picchia, Paulo 1892-.Crime d'aquella noite

FFLCH-LE /869.935^M517c

Coelho Neto, Henrique Maximiano 1864-1934.Quintas janeiro de 1921 a dezembro de 1923

FFLCH-LE /869.9447^C618q

Amaral, Amadeu 1875?-1929.0 elogio da mediocridade estudos e notas de literatura

FFLCH-LE /869.945^A512e

Bilac, Olavo 1865-1918. Ultimas conferencias e discursos

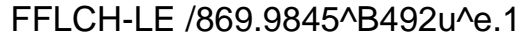

Almeida, Guilherme de 1890-1969. Natalika

FFLCH-LE /869.985^A447n^1924^e.1

Santos, Daltro. Palavras a' juventude discursos e conferencias

FFLCH-HI /869.5^S256p

Cardoso, Vicente Licínio 1889-1931.Pensamentos brasileiros golpes de vista

FFLCH-LE /869.945^C268p

Callage, Roque. Rinção (scenas da vida gaúcha)

FFLCH-LE /869.935^C16r^2.ed 
Campos, Humberto de. A bacia de pilatos

FFLCH-HI /CE^909^2.ed

Ribeiro Couto, Rui. Poemetos de ternura e de melancolia ; um homem na multidao FFLCH-LE /869.915^R368p

Fortes, M. Pereira. Cantares da minha terra versos gauchos

FFLCH-LE /869.915^F845c

Moraes, Durval Borges de. Cheia de graça

FFLCH-LE /869.9149^M819c

Silva, Julio Cesar da. Arte de amar

FFLCH-LE /869.9149^S58a

Rangel, Alberto. Lume e cinza

FFLCH-LE /869.935^R154I

Braga, Belmiro. Rosas versos

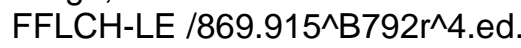

\section{5}

Ribeiro, Julio 1845-1890. Padre Belchior de Pontes romance historico original

FFLCH-HI /CE^4412

Almeida, Guilherme de 1890-1969. Meu

FFLCH-LE /869.915^A477f

FFLCH-LE /869.915^A447r

Menotti del Picchia, Paulo 1892-. Juca mulato

FFLCH-LE /869.915^M517j^5.ed

Azeredo, Carlos Magalhaes de. Symphonia evangelica

FFLCH-LE /869.915^A985s

Tigre, Manuel Bastos. Poema da primeira infancia poesias lyricas

FFLCH-LE /869.915^T448p

Azambuja, Darcy 1903-1970. No galpão (contos gaúchescos)

FFLCH-LE /869.935^A984n^2.ed

Ballao, Jayme. Seara morta novellas de paisagens emotivas e almas humildes

FFLCH-LE /869.935^B144s

Coelho Netto, Henrique 1864-1934. Água de juventa

FFLCH-LE /869.9347^C618a

Setubal, Paulo de Oliveira. Marqueza dos Santos

FFLCH-LE /869.935^S522m

Coelho Neto, Henrique Maximiano 1864-1934. Bico de pena fantasias, contos e perfis : 1902-1903 FFLCH-LE /869.9447^C618bi^3.ed

Almeida, Guilherme de 1890-1969. Raça 
FFLCH-LE /869.915^A447^^1925

Peixoto, Afranio. Razoes do coração

FFLCH-LE /869.935^P43r

Tavares, Adelmar. Linda mentira

FFLCH-LE /869.935^T288I

Bananére, Juo 1892-1933. La Divina Increnca

FFLCH-HI /CE^297

Floreal, Sylvio. A coragem de amar

FFLCH-HI /CE^1979

Mariano, Olegário 1889-1958.Ultimas cigarras

FFLCH-HI /CE^3321

Azevedo, Aluisio. O cortico

FFLCH-LE /869.9345^A986ci^1925

Cancioneiro alegre de poetas portugueses e brasileiros, comentado

FFLCH-LE /869.08^Can222^3.ed.^v.1

FFLCH-LE /869.08^Can222^3.ed.^^v.2

Miranda, Joao Pedro da Veiga. A serpente que dansa

FFLCH-LE /869.935^M643s

\section{6}

Coelho Netto, Henrique 1864-1934. Rei negro romance bárbaro

FFLCH-LE /869.9347^C618r^2.ed

Süssekind de Mendonça, Carlos. Historia do theatro brasileiro Vol. $1^{\circ}$ (1565-1840).

FFLCH-LE /869.9209^M494h

Silveira, Tasso da. Alegorias do homem novo

FFLCH-LE /869.915^S591a

Magalhães, Basílio de 1874-. Bernardo guimaraes esboco biografico e critico

FFLCH-LE /869.9333^G9761 ${ }^{\wedge} \mathrm{e} .1$

Avelino, José. Memórias de João Barriga; [Crit] Alcides Maya

FFLCH-LE /869.935^A967m

Coelho Netto, Henrique 1864-1934. Miragem

FFLCH-LE /869.9347^C618mir^4.ed

Peixoto, Afrânio 1876-1947. Páginas escolhidas

FFLCH-LE /869.935^P43p

FFLCH-LE /869.935^P43p^e.2

Monteiro Lobato, Jose Bento. Choque das racas ou o presidente negro romance americano do anno de 2228

FFLCH-HI /CE^3613

FFLCH-LE /869.935^M778ch 
Carvalho, Ronald de 1893-1935. Toda a América ..

FFLCH-LE /869.915^C327t^ex.1

Karam, Francisco. Palavras de orgulho e de humildade

FFLCH-LE /869.915^K27p

Oliveira, Felippe de 1891-1933. Lanterna verde

FFLCH-LE /869.9149^O47I

Ribeiro, João 1860-1934. Cartas devolvidas

FFLCH-LE /869.9349^R37c

Leite, Aureliano 1886-. Brio de caboclo contos

FFLCH-HI /CE^3014

França Júnior 1838-1890. Folhetins

FFLCH-LE /869.9849^F881f^4.ed.

Salgado, Plínio 1895-. O extrangeiro (chronica da vida paulista)

FFLCH-LE /869.985^S159e

Taunay, Afonso de E.Leonor de avila romance historico brasileiro seiscentista FFLCH-HI /CE^5053

Neiva, Arthur. Daqui e de longe chronicas nacionaes e de viagem

FFLCH-HI /CE^3730

Almeida, Júlia Lopes de 1862-1934. Historias Da Nossa Terra

FFLCH-LE /869.935^Al448h

Campos, Humberto de 1886-1934. O arco de Esopo [por] Conselheiro X.X. Continuação de Pombos de Mahomet, 1925

FFLCH-HI /CE^908

Cunha, Euclydes da. A marjem da historia

FFLCH-HI /CE^1381

Fradique, Mendes. Doutor voronoff

FFLCH-HI /CE^2013

Barreto, Tobias. Obras completas

FFLCH-LE /869.945^B2640^v.9.

\section{7}

Pompêo, Antonio 1885-. Idéas, homens e livros

FFLCH-HI /869.9^P788i

Duarte, Paulo 1899-. Agora nós! Chronica da revolução paulista, com os perfis de alguns heroes da retaguarda

FFLCH-LE /981.61^D812a

Abreu, Benedito Luis Rodrigues de. Casa destelhada e outros poemas

FFLCH-LE /869.915^A145c 
Menotti del Picchia, Paulo 1892-.Angústia de Don João

FFLCH-LE /869.915^M517a^1927

Araujo, Murillo. Illuminacao da vida

FFLCH-LE /869.915^A69i

Coelho Netto, Henrique 1864-1934. Banzo

FFLCH-LE /869.9347^C618b^2.ed^e.1

Coelho Neto, Henrique Maximiano 1864-1934.Contos da vida e da morte

FFLCH-LE /869.9347^C618co

Pati, Francisco 1. Maria leocadia

FFLCH-LE /869.935^P337m^2.ed

Menotti del Picchia, Paulo 1892-.Curupira e o Carão(Paulo Menotti Del Picchia, Plinio Salgado, Cassiano Ricardo)

FFLCH-LE /869.985^M517c

Amaral, Leopoldo Augusto do. Campinas recordações

FFLCH-HI /981.61^A485c

FFLCH-LE /869.985^A515c

Navarro de Andrade, Edmundo 1881-1941. Por ahi além impressões de viagem

FFLCH-LE /869.985^Ae566p

Constantino, Antonio. Este e o canto da minha terra...

FFLCH-LE /869.915^C774e

Setúbal, Paulo 1893-1937. As maluquices do imperador

FFLCH-HI /CE^4756

Fradique, Mendes 1893-1944. Historia Do Brasil Pelo Methodo Confuso

FFLCH-HI /CE^2014.

Edmundo, Luiz 1878-1961.De algumas fabulas de Trilussa

FFLCH-LE /869.935^C873d

Vautel, Clement. Uma menina sem cerimonia romance

FFLCH-HI /CE^5284

Morais, Raimundo. Cartas da floresta

FFLCH-LE /869.985^M826c

Thiollier, Rene. O homem da galeria echos de uma epoca

FFLCH-LE /869.935^T372h

Ribeiro, João 1860-1934. Autores contemporaneos excerptos de escriptores brazileiros e portuguezes contemporaneos

FFLCH-LE /869.9349^R369a^16.ed.

Santos, Marina Quirino dos. Vozes do coração

FFLCH-LE /869.915^M265v

Fontes, Joaquim Martins 1884-1937. O collar partido 
FFLCH-LE /869.9549^M343C

\section{8}

Muir, Edwin. Estrutura do romance

FFLCH-LE /801.953^M921sP

FFLCH-LE /801.953^M921sP^e.2

Almeida, Guilherme de 1890-1969. Livro de horas de soror dolorosa "a quem morreu de amor" FFLCH-LE /869.915^A447I

Anjos, Augusto dos 1884-1914. Eu e outras poesias

FFLCH-LE /869.9148^A619e^3.ed..

Almeida, Paulo Mendes de. Cartazes

FFLCH-LE /869.915^Ap45c

Almeida, José Américo de 1887-. A bagaceira

FFLCH-LE /869.935^A448b^3.ed..

Almeida, Júlia Lopes de 1862-1934. Cruel amor

FFLCH-LE /869.935^al448cr

Coelho Netto, Henrique 1864-1934. Vesperal

FFLCH-LE /869.9347^C618ve^2.ed

Coelho Neto, Henrique Maximiano 1864-1934. Mano

FFLCH-LE /869.985^C618ma^2.ed

Castro, Aloysio de 1881-. Os carmes de Aloysio de Castro

FFLCH-HI /869.1^C355c

Cearense, Catullo da Paixão 1863-1946. Alma do sertão Desafios, A mulher julgada pelos homens FFLCH-LE /869.915^C38a

Meyer, Augusto 1902-1970. Giraluz

FFLCH-LE /869.915^M559g

Setúbal, Paulo 1893-1937.A bandeira de Fernão Dias

FFLCH-HI /CE^4751

Peixoto, Afrânio 1876-1947. Uma mulher como as outras

FFLCH-LE /869.935^P43u^1928

Lima, Alceu Amoroso 1893-. Estudos,

FFLCH-LE /869.909^L696es^2.ser

Octavio, Rodrigo 1866-1944.Coração aberto livro de saudades

FFLCH-LE /869.985^O18c

Ellis Junior, Alfredo 1896-.Pedras lascadas

FFLCH-HI /CE^1792

Cavaco, Carlos. Musa vermelha 
FFLCH-LE /869.915^C363m

Campos, Humberto de. Gansos do capitólio

FFLCH-HI /CE^912

Ellis Junior, Alfredo 1896-. O thesouro de Cavendish romance historico brasileiro

FFLCH-HI /CE^1796

Carvalho, Vicente de 1866-1924. Poemas e cancoes

FFLCH-LE /869.9149^C329p^8 ed

Oliveira, Alberto de 1857-1937. Poesias

FFLCH-LE /869.9146^O45p^2.ed

Pereira Tavares, José org.Poetas do amor Edição organizada por José Pereira Tavares

FFLCH-LE /869.08^Pam798

Souza, Claudio de 1876-1954. De Paris ao Oriente

FFLCH-LE /869.9349^S714d^v.2^3.ed...

\section{9}

Almeida, Guilherme de 1890-1969. Simplicidade versos escritos entre 1910 e 1916

FFLCH-LE /869.915^A447s

Pires, Homero. Junqueira freire, sua vida, sua epoca, sua obra

FFLCH-LE /869.9135^J941p^ex.1

FFLCH-LE /869.9135^J941p^e.2

Olympio, Domingos 1850-1906. Luzia-Homem Prefacio de Gustavo Barroso

FFLCH-LE /869.9349^O39/^2.ed

Aranha, Graça 1868-1931. A viagem maravilhosa

FFLCH-LE /869.9348^G753v

Peixoto, Afrânio 1876-1947. Sinházinha

FFLCH-LE /869.935^P43s^1929

Lessa, Origenes. Escriptor prohibido

FFLCH-LE /869.935^L632e

Azevedo, Fernando de 1894-1974.Ensaios critica literaria para "o estado de sao paulo" 1924-1925

FFLCH-LE /869.9445^A987e

Meyer Junior, Augusto. Poemas de bilu

FFLCH-LE /869.915^M559po

Orico, Osvaldo 1900-. A vida de José de Alencar

FFLCH-LE /869.9334^A35310

Azevedo, Arthur 1855-1908. Vida alheia livro posthumo Arthur Azevedo ; prefacio de Chrysanthème e autobiographia do autor

FFLCH-HI /CE^257

Sette, Mário 1886-1950. As contas do terço 
FFLCH-HI /CE^4749

Tavora, Joao Franklin da Silveira. O matuto

FFLCH-LE /869.9342^T237m

Feira literaria

FFLCH-LE /869.908^F332^v.1

\section{0}

Setubal, Paulo. Nos bastidores da historia

FFLCH-HI /CE^4758

Bilac, Olavo 1865-1918. Poesias

FFLCH-LE /869.9148^B492p^14.ed

Bandeira Filho, Manuel. Libertinagem

FFLCH-LE /869.915^B166I

Valerio, Americo. Machado de Assis e a psychanalyse

FFLCH-LE /869.9341^ex.1^m1291va

FFLCH-LE /869.9341^ex.2^m1291va

Correa, Viriato. Bahu velho roupas antigas da historia do brasileiro

FFLCH-LE /869.985^C846ba^2.ed...

Menotti del Picchia 1892-.A republica 3.000

FFLCH-LE /869.935^M517r

Bilac, Olavo 1865-1918. Conferencias literárias

FFLCH-LE /869.9845^B $492 \mathrm{c}^{\wedge} 2 . \mathrm{ed}^{\wedge} \mathrm{e} .1$

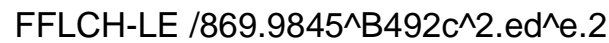

Motta, Arthur 1879-. Historia da litteratura brasileira

FFLCH-LE /869.909^M873h^v.1^e.1

Calmon, Pedro 1902-. José de Anchieta o santo do Brasil

FFLCH-HI /CE^857

FFLCH-LE /869.911^A554cp^1930

Amaral, Azevedo 1881-. Ensaios brasileiros

FFLCH-LE /869.9449^A512e

Pinto da Silva, João. Historia literaria do Rio Grande do Sul FFLCH-LE /869.909^S58h^2.ed...

Orico, Osvaldo. Mitos amerindios sobrevivencias na tradicao e na literatura brasileira FFLCH-LE /398.4^O78m

Motta, Leonardo. No tempo de Lampeão

FFLCH-HI /869^M921n

Ribeiro, Júlio. A carne 
FFLCH-HI /CE^4411

Souza, Claudio de 1876-1954.As mulheres fataes (romance)

FFLCH-HI /CE^4896..

Orico, Oswaldo. O demonio da rejencia

FFLCH-HI /CE^3848

\section{1}

Cunha, Euclydes da 1866-1909. Cartas de Machado de Assis e Euclydes da Cunha coligidas por Renato Travassos

FFLCH-LE /869.965^T712^1931

Peixoto, Afrânio 1876-1947. Missangas; poesia e folklore FFLCH-LE /398.981^^43m^1931

Amaral, Amadeu 1875?-1929.Poesias Amadeu Amaral *

FFLCH-HI /CE^89

FFLCH-LE /869.915^A512p^ex.1

Flórez, Julio 1867-1923. Poesias

FFLCH-LE /869.9148^B492p^15.ed

Peixoto, Afrânio 1876-1947. Noções de historia da literatura brasileira

FFLCH-LE /869.909^P43nb

FFLCH-LE /869.909^P43nb^e.2

Carvalho, Ronald de 1893-1935. Estudos brasileiros 2. e 3. series

FFLCH-LE /869.909^2-3ser^ex.2^c321est

FFLCH-LE /869.909^R327e^ex.1

Menotti del Picchia 1892-. Lais (romance)

FFLCH-LE /869.935^M517/^5.ed

Ozorio de Almeida, Miguel 1890-. A vulgarização do saber; ensaios

FFLCH-LE /869.945^A449v

Bilac, Olavo. Contos patrios para creancas Olavo Bilac, Paulo Coelho Neto

FFLCH-LE /869.9845^B492Co^27.ed

Albuquerque, Medeiros e 1867-1934. Por alheias terras .

FFLCH-LE /869.9849^M438p

Vicente de Azevedo, Vicente de Paulo. Alvares de Azevedo dados para a sua biografia FFLCH-LE /869.9134^A4721av..

Abreu, João Capistrano de 1853-1927.Ensaios e estudos (critica e historia) 1a. [- ] série FFLCH-GE $/ 981^{\wedge} \mathrm{A} 162 \mathrm{e}^{\wedge} \mathrm{V} .1$..

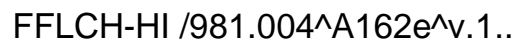

Morais, Raimundo de 1872-1941. O meu diccionario de cousas da Amazonia

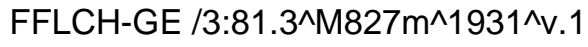

Taunay, Alfredo D'escragnolle Taunay, Visconde de. Brasileiros e estrangeiros 
FFLCH-LE /869.9343^^223b

Ribeiro, João 1860-1934. Floresta de exemplos FFLCH-LE /869.9394^R369fl..

Nascimento, Alba Canizares. Capistrano de Abreu o homem de a obra FFLCH-HI /CE^3721

Miranda, Alfredo do Botelho. Conto e 40 poemas

FFLCH-HI /CE^3560

Delafosse, Maurice. Negros.

FFLCH-HI /301^D333n

Carmilo, Edvard. Humildade poemas em prosa

FFLCH-LE /869.915^C284h

Campos, Cleómenes 1895-. Humildade

FFLCH-HI /CE^903

Costallat, Benjamim 1897-1961. Mysterios do Rio

FFLCH-HI /CE^1316

Barroso, Gustavo. Heroes e bandidos os cangaceiros do nordeste

FFLCH-LE /869.935^B285h^2.ed.

Lopes, Elcias. Teia de aranha

FFLCH-HI /CE^3154

\section{2}

Peixoto, Afranio. Nocoes de historia e literatura geral

FFLCH-LE /801^P43n

Amaral, Edmundo. Rotulas e mantilhas evocacoes do passado

FFLCH-LE /869.985^Ae512^^^1932

Mendes, Murilo 1901-1975. Historia Do Brasil

FFLCH-LE /869.915^M492h^ex.1

Peixoto, Afrânio 1876-1947. Autos

FFLCH-LE /869.925^P43au

Vieira, Celso 1878-. Para as lindas maos; [Pref] Oswaldo Orico

FFLCH-LE /869.9349^V714p

Casasanta, Mario. Minas e os mineiros na obra de Machado de Assis

FFLCH-LE /869.9341^m1291cm..

Octavio, Rodrigo 1866-1944. Contos de hontem e de hoje FFLCH-LE /869.935^Oc18c 
Rio, João do 1881-1921. Celebridades desejo Paulo Barreto [i.e. J. do Rio]

FFLCH-LE /869.985^B264c

Pedro li, Imperador do Brasil. Poesias completas de Pedro II originais e traducoes, sonetos do exilio, autenticas e apocrifas

FFLCH-LE /869.9136^P413p

Gentil, Alcides. Ideas de alberto torres

FFLCH-HI /CE^2185

Abreu, Joao Capistrano de. Ensaios e estudos critica e historia: 2. serie

FFLCH-HI /CE^11

Irajá, Hernani de. Feitiços e crendices

FFLCH-FI /398.30981^165f

FFLCH-FI /398.30981^165f^e.2

Lobato, José Bento Monteiro 1882-1948. América

FFLCH-HI /970^L796a

Pereira, Baptista 1880-1960. A illusão russa

FFLCH-HI /CE^3968

Barroso, Gustavo. A senhora de pangim (romance)

FFLCH-LE /869.935^B285se^1932

\section{3}

Coaracy, Vivaldo. Sala da capela

FFLCH-LE /869.935^C583s

Grieco, Agrippino 1888-1973. Evolução da prosa brasileira

FFLCH-LE /801.95^G683ep

FFLCH-LE /801.95^G683ep^e.2

Barroso, Gustavo 1888-1959. A ronda dos seculos

FFLCH-LE /869.935^B285r^3.ed

Couto, Rui Ribeiro 1898-1963. Bahianinha e outras mulheres

FFLCH-LE /869.935^R368b^2.ed

Correa, Viriato. Mata gallego historia da "noite das garrafadas" e outras historias FFLCH-LE /869.985^C846m

Couto, Rui Ribeiro 1898-1963. Club das esposas enganadas

FFLCH-LE /869.935^R368c/^1933

Lessa, Orígenes 1903-. Ilha Grande (do jornal de um prisioneiro de guerra)

FFLCH-LE /869.985^L632i

Rebelo, Marques 1907-1973. Tres caminhos 
FFLCH-LE $/ 869.935^{\wedge} \mathrm{M} 32 \operatorname{tr}^{\wedge} \mathrm{e} .1$

FFLCH-LE $/ 869.935^{\wedge} \mathrm{M} 32 \operatorname{tr}^{\wedge} \mathrm{e} .2$

Almeida, Guilherme de 1890-1969. Meu Portugal

FFLCH-LE $/ 869.9849^{\wedge} \mathrm{A} 447 \mathrm{~m}^{\wedge} \mathrm{e} .1$

FFLCH-LE $/ 869.9849^{\wedge} \mathrm{A} 447 \mathrm{~m}^{\wedge} \mathrm{e} .2$

Pedro II Emperor of Brazil 1825-1891. Cartas do imperador d. Pedro II ao barão de Cotegipe ordenadas e annotadas por Wanderley Pinho

FFLCH-FI /981.04^P654C..

Menotti del Picchia 1892-. Jesus tragedia sacra

FFLCH-HI /CE^4036

Setúbal, Paulo 1893-1937. O irmãos Leme

FFLCH-HI /CE^4755

Ozorio de Almeida, Miguel 1890-. Almas sem abrigo

FFLCH-LE /869.935^A449a..

Setúbal, Paulo 1893-1937. O ouro de Cuiabá

FFLCH-HI /CE^4760

Campos, Humberto de. Memorias. Primeira parte 1886-1900 Humberto de Campos *

FFLCH-HI /CE^914^v.1^pt.1

Peregrino Júnior, João 1898-. Matupá (typos e costumes da Amazonia)

FFLCH-LE /869.935^P488m

Barroso, Gustavo 1888-1959. O Santo do Bréjo

FFLCH-LE /869.935^B285s

Sylos, Honório de. Itararé! Itararé! .. Notas de campanha

FFLCH-GE /981.061^S984i

FFLCH-HI /CE^4992

Calmon, Pedro 1902-. O rei cavalleiro a vida de D. Pedro I

FFLCH-HI /CE^859

FFLCH-LE $/ 920^{\wedge} \mathrm{P} 413 \mathrm{C}$

Amaral, Luis Gurgel do. Contos fora de tempo

FFLCH-LE $/ 869.93^{\wedge}$ A515c^cep

Campos, Humberto de 1886-1934. Crítica Humberto de Campos Primeira série

FFLCH-HI /CE^910^2.ed

Campos, Humberto de 1886-1934. Crítica Humberto de Campos Segunda série FFLCH-HI /CE^911

Campos, Humberto de. O monstro e outros contos

FFLCH-HI /CE^915^2.ed

Campos, Humberto de 1886-1934. Lagartas e libélulas (cronicas)

FFLCH-HI /CE^913

Peixoto, Afrânio 1876-1947. Fruta do mato 
FFLCH-HI /CE^3946

Martins Fontes, Jose. Terras da fantasia

FFLCH-LE /869.9149^M343t..

\section{4}

Carvalho, Affonso de 1897-1953. A poetica de Olavo Bilac

FFLCH-LE /869.9148^b4921ca

Alves, Castro. Hymnos do equador Castro Alves ; [Intr] Afranio Peixoto

FFLCH-LE /869.9145^C35hy

Campos, Cleomenes. Coracao encantado

FFLCH-LE /869.915^Ca211c^2.ed

Vianna Filho, Oduvaldo. Teatro: Amor .. satira em 3 atos e 38 quadros; Canção da felicidade, romance de figuras animadas, em 3 vols. e 8 capitulos

FFLCH-LE /869.925^Vo671te

Barretto Filho 1908-. Sob o olhar malicioso dos trópicos

FFLCH-LE /869.935^B266s^2.ed

Albuquerque, Medeiros e 1867-1934. Surprezas (contos)

FFLCH-LE /869.9349^M438su

Amorim, Clóvis 1911-1970. O alambique romance

FFLCH-LE /869.935^A543a

Costa Filho, Odylo. Graca aranha e outros ensaios ensaios de critica brasileira

FFLCH-LE /869.9348^G7531c

Pujol, Alfredo. Curso literario em sete conferencias na sociedade de cultura artistica de sao paulo FFLCH-LE /869.9341^M1291p^2.ed^e.1

Couto, Rui Ribeiro 1898-1963. Presença de Santa Teresinha. Ilustrações de Cândido Portinari

FFLCH-LE /869.935^R368p^1934

Lima, Alceu Amoroso 1893-. Estudos; 2a serie (Tristão de Athayde)

FFLCH-LE /869.909^L696es^2.ser

Lima, Jorge de 1893-1953. Anchieta

FFLCH-HI /920^A539I

FFLCH-LE /869.911^A5541Lj^1934

Piccarolo, Antonio 1863-1947. Entre a Ciência e a arte (conferências e prolusões)

FFLCH-FI /504^P587e

Rangel, Alberto 1871-1945.Rumos e perspectivas discursos e conferencias

FFLCH-GE /3:88^R196r^2.ed.

Pereira, Baptista 1880-1960. Figuras do imperio e outros ensaios FFLCH-HI /923.281^P436f

Setúbal, Paulo 1893-1937. El-Dorado; ilustrações de J. Wasth Rodrigues 
FFLCH-HI /CE^4753

Bastos, Abguar. Terra de Icamiaba (romance da Amazonia)

FFLCH-LE /869.935^B326t^2.ed.

Andrade, Oswald de. Escada vermelha

FFLCH-LE /869.935^An568e

Ellis Junior, Alfredo 1896-.A madrugada paulista lendas de Piratininga

FFLCH-HI $/ 981.6^{\wedge} \mathrm{E} 47 \mathrm{ma}$

FFLCH-LE /869.93^E43m

Tavares, Adelmar. A luz do altar palavras de louvor e de saudade

FFLCH-LE /869.904^T288lu..

Campos, Humberto de 1886-1934. A sombra das tamareiras contos orientais

FFLCH-HI /CE^916

Cearense, Catullo. Fabulas e allegorias

FFLCH-HI /CE^1047

Campos, Humberto de 1886-1934. Sombras que sofrem crônicas

FFLCH-HI /CE^917

Neves-Manta, I. De L..A arte e a neurose de João do Rio a individualidade e a obra mental de joao do rio em face da psychiatria

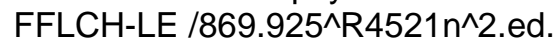

FFLCH-LE /869.925^R4521n^2.ed.^e.2

Carneiro, A. J. de Souza. Furundungo romance

FFLCH-LE /869.935^C287f

Victorino, Jose. Poetas capichabas

FFLCH-LE /869.908^P798

Mennucci, Sud. Humor

FFLCH-LE /869.9749^M516h^2.ed...

\section{5}

Simonsen, Roberto Cochrane 1889-. Aspectos da política econômica nacional; discurso pronunciado na Camara federal dos deputados, em 11 de setembro de 1935 ..

FFLCH-HI /CE^4832

Nina Rodrigues, Raymundo 1862-1906. O animismo fetichista dos negros bahianos; prefacio e notas de Arthur Ramos

FFLCH-FI /264.1^R696an^e.1

Calmon, Pedro 1902-. Vida e amôres de Castro Alves (com ilustrações do poéta)

FFLCH-LE /869.9145^C351cV

Tigre, Manuel Bastos. Entardecer

FFLCH-LE /869.915^T448e

Almeida, José Américo de 1887-. O boqueirão 
FFLCH-LE /869.935^A448bo

Almeida, José Américo de 1887-. Coiteiros

FFLCH-LE /869.935^A448c^2.ed

Carvalho, Ronald de 1893-1935. Caderno de imagens da Europa

FFLCH-LE $/ 869.985^{\wedge} \mathrm{C} 327 \mathrm{c}^{\wedge} \mathrm{e} .1$

Belmonte. Ideias de joao ninguém

FFLCH-LE /869.975^B389i

Couto, Rui Ribeiro 1898-1963. Chão de França

FFLCH-LE /869.985^R368ch^e.1

Couto, Rui Ribeiro 1898-1963. Conversa inocente crônicas

FFLCH-LE /869.985^R368co^e.1

Andrade, Mario de 1893-1945. O Aleijadinho e Alvares de Azevedo

FFLCH-LE /869.945^A568a^1935

Barros, João de 1881-1960. O Caramuru aventuras prodigiosas dum português colonizador do Brasil / adaptação em prosa do poema épico de frei José de Santa Rita Durão por Joao de Barros FFLCH-LE /869.9121^S222cb

Machado, Dyonelio 1895-. Os ratos

FFLCH-LE /869.935^M13r^1935

Penna, Cornélio. Fronteira, romance FFLCH-LE /869.935^P459f

Carvalho, Ronald de 1893-1935. Itinerario: Antilhas, Estados Unidos, Mexico FFLCH-LE /869.985^C327i

Salles, Albano. Chanceller da paz FFLCH-LE /869.9149^S162c

Ramos,Arthur. O folk-lore negro no brasil demopsychologia e psychanalise FFLCH-HI /301.45196^R175f^e.1

Campos, Humberto de. Critica primeira a terceira series

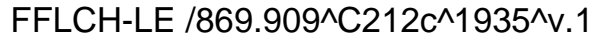

Santos, Maximo de Moura. O professor polycarpo

FFLCH-LE /869.985^S236p

\section{6}

Machado, Alcântara 1875-1941.Gonçalves de Magalhães, ou, O romântico arrependido FFLCH-LE /869.9132^G6271a

Gurgel, Leoncio do Amaral. Ensaios quinhentistas estudos historicos FFLCH-HI /CE^2382

Calógeras, João Pandiá 1870-1934. Problemas de governo 
FFLCH-HI $/ 981^{\wedge} \mathrm{B} 823^{\wedge} \mathrm{V} \cdot 67^{\wedge} 2 . \mathrm{ed}$

Soares, Teixeira. Machado de Assis ensaio de interpretacao

FFLCH-LE /869.9341^ex.1^m1291st

Camargo, Joracy. Deus Ihe pague... Comedia em 3 atos divididos em 9 quadros Joracy Camargo ; [Pref] Ferreira, Procopio

FFLCH-LE $/ 869.925^{\wedge} \mathrm{C} 178 \mathrm{~d}^{\wedge} 1936$

Paixao, Mucio da. Theatro no brasil obra posthuma FFLCH-LE /869.9209^P172t^e.1

Veríssimo, José. Letras e literatos estudinhos criticos da nossa literatura do dia: 1912-1914

FFLCH-LE /869.909^V619le

Monteiro, Mário Ypiranga. Bilac e Portugal

FFLCH-LE /869.9148^B4921m

Machado, Antônio de Alcântara 1901-1935. Mana Maria *

FFLCH-LE /869.935^A319m

Almeida, José Américo de 1887-. A bagaceira romance

FFLCH-LE /869.935^A448b^6.ed

Romero, Sílvio 1851-1914. Machado de Assis

FFLCH-LE /869.9341^M1291^^2.ed

Ramos, Graciliano. Angústia; [II] Tomas Santa Rosa

FFLCH-LE /ESP^R143an

Corrêa, Viriato.Casa de belchior

FFLCH-LE /869.985^C846c

Vergara, Telmo. Cadeiras na calcada

FFLCH-LE /869.935^V612c.

Vieira, Jose Geraldo. Territorio humano

FFLCH-LE /869.935^^715t^1936

Barros, Jayme de 1901-. Espelho dos livros (estudos literarios)

FFLCH-LE /869.945^B278e

Bello, José Maria 1880-. Imagens de ontem e de hoje

FFLCH-LE /869.945^B39i..

Peixoto, Afranio. Humour ensaio de breviario nacional do humorismo

FFLCH-LE /869.975^P43h^2.ed..

Homenagem a Manuel Bandeira

FFLCH-LE /869.915^B1661ho

Moura, Emílio. Canto da hora amarga

FFLCH-LE /869.915^M885c

Cunha, Tristão da 1878-1942. Historias do bem e do mal Edição da Sociedade Felippe d'Oliveira FFLCH-LE /869.935^C98h^1936 
Milliet, Sérgio 1898-1966. Marcha á ré

FFLCH-LE /869.985^M593m

Arinos, Afonso 1868-1916. Pelo sertão

FFLCH-HI /CE^164

Coaracy, Vivaldo 1882-. Zacarias

FFLCH-LE /869.985^C583z

Carvalho, Flávio de Rezende 1899-1973. Os ossos do mundo

FFLCH-LE /869.935^C323os

Campos, Humberto de 1886-1934.Crítica Quarta série Organisado e rev. por Henrique Campos

FFLCH-LE /OBRA ESP.^00408

Salgado, Plínio 1895-. Palavra nova dos tempos novos

FFLCH-HI /CE^4598

Cardoso, Lucio. A luta contra a morte

FFLCH-LE $/ 869.935^{\wedge} \mathrm{C} 264 L^{\wedge} \mathrm{V} .1$

Fernandes, Carlos Dias. Fretana romance

FFLCH-LE /869.935^Fc399f

Palhano, Lauro (Pseud.). Marupiara romance

FFLCH-LE /869.935^P188m

Bittencourt, Liberato. Novas dezenas de imortais ou vinte teoremas de psicologia literaria FFLCH-LE /869.945^B544n^v.3.

Bevilaqua, Amelia de Freitas. Vesta (romance)

FFLCH-LE /869.935^B467v^3.ed...

\section{7}

Rebêlo Gonçalves, Francisco da Luz 1907-. Filologia e literatura

FFLCH-LE /469^R234f^ex.1

Accioli, Joao. Olho d'agua

FFLCH-LE /869.915^A1550..

Ribeiro Neto, Oliveira 1908-. Estrêla d'Alva

FFLCH-LE /869.915^R37es

Carneiro, Edison. Castro alves ensaio de compreensao

FFLCH-LE /869.9145^C351ce

Dias, Gonçalves 1823-1864.Cantos de amor Prefácio e notas de M. Nogueira da Silva FFLCH-LE /869.9133^G625c

Prisco, Francisco. José Verissimo sua vida e suas obras FFLCH-LE /869.909^V619p

Lins, Edison.... Historia e critica da poesia brasileira 
FFLCH-LE /869.9109^L731h..

Amado, Jorge 1912-. Capitães da areia romance FFLCH-LE /869.935^A494cp^1937

Amado, Jorge 1912-. Jubiabá romance

FFLCH-LE /869.935^A494j^2.ed

Azevedo, Aluisio. Condessa vesper

FFLCH-LE /869.9345^A986co

Peixoto, Afrânio 1876-1947. As razões do coração

FFLCH-LE /869.935^P43r^2.ed

Moraes, Carlos Dante de. Tristão de Athayde, e outros estudos FFLCH-LE /869.945^L9691m..

Lessa, Orígenes 1903-. O joguete

FFLCH-LE /869.935^L632j

Moog, Clodomir Vianna 1906-. Novas cartas persas FFLCH-LE /869.935^M81n..

Tigre, Manoel Bastos. Uma coisa e outra FFLCH-LE /869.985^T448u

Rebelo, Marques 1907-1973. Oscarina FFLCH-LE /869.935^M320^2.ed

Seidl, Roberto. Artur de azevedo ensaio bio-bibliografico FFLCH-LE /R016.8699^S46a..

Lima, Joao Francisco de Araujo. Amazônia a terra e o homem FFLCH-HI /CE^3097

FFLCH-GE /304.20981^L732d^2.ed

Camargo, Joracy 1898-1973. Teatro brasileiro teatro infantil FFLCH-LE $/ 028.5^{\wedge} \mathrm{C} 178 \mathrm{t}$

Kelly, Prado. Chronica de nossos dias, 1934-1935

FFLCH-LE /869.9849^K39c

Rebêlo Gonçalves, Francisco da Luz 1907-. Dissertações camonianas

FFLCH-LE /869.124^C1921g

Silveira, Valdomiro. Mixuangos contos

FFLCH-LE /869.9349^S591mi^1937

Ricardo, Cassiano. Brasil no original

FFLCH-HI /981^R488b

FFLCH-LE /981^R376b^2.ed

Adonias Filho. Renascimento do homem FFLCH-LE /869.945^A186r 
Barroso, Gustavo 1888-1959. A sinagoga paulista

FFLCH-LE /869.9849^B285s^3.ed

Bandeira, Manuel 1886-1968. Crônicas da província do Brasil

FFLCH-HI /981^B214c

FFLCH-LE $/ 869.985^{\wedge} \mathrm{B} 166 \mathrm{cr}^{\wedge} \mathrm{ex} .1$

FFLCH-LE /869.985^B166 $\mathrm{cr}^{\wedge} \mathrm{ex} .2$

Fontes, Martins. Indaia ; livro postumo

FFLCH-HI /869.1^M386i

FFLCH-LE /869.9149^M343i

Tigre, Manuel Bastos. As parabolas de christo e outras poesias

FFLCH-LE /869.915^T448pa^2.ed.

Fontes, Martins 1884-1937. Canções do meu vergel

FFLCH-LE /869.9149^M343c

Almeida, Fernando Mendes de. Carrussel fantasma; poesia

FFLCH-HI /CE^55

Castro, Ferreira de 1898-. A selva; prefaciada por Afranio Peixoto

FFLCH-HI /CE^1021

Setubal, Paulo. Confiteor obra postuma

FFLCH-HI /CE^4752

Silveira, Tasso da. 30 espitritos-fontes

FFLCH-LE /869.945^S591t

Azevedo, Aluizio. O cortico

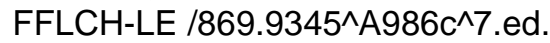

Melo Franco, Afonso Arinos de. Espelho de tres faces

FFLCH-LE /869.945^M485e

\section{8}

Reboucas, Andre. Diario e notas autobiograficas

FFLCH-GE /25^R292d^1938

FFLCH-HI /920^R292

Campos, Calazans de. Marcha heróica

FFLCH-LE /869.915^C211m

Alves, Mario. Borbulhas poesia

FFLCH-LE /869.915^A481b

Bandeira, Manuel 1886-1968 comp. Antologia dos Poetas Brasileiros da Fase Parnasiana FFLCH-LE /869.9108^B166ap

Júnior, Jaime Balão. Impressões literárias

FFLCH-LE /869.909^B144i

Silva, Fafayette. Historia do teatro brasileiro 
FFLCH-LE /869.9209^S581h^1938

Lima, Jorge de 1893-1953. A túnica inconsutil poesia

FFLCH-LE /869.915^L698t^ex.1

Anjos, Cyro dos 1906-. O amanuense Belmiro

FFLCH-LE /869.935^A619am^2.ed

Alphonsus, João 1901-1944.Rola - moça romance

FFLCH-LE /869.935^A651r..

Azevedo, Alvares de. Noite na taverna contos fantasticos

FFLCH-LE /869.9334^A472n^1938

Cardoso, Lúcio 1913-1968. Mãos vasias novela

FFLCH-LE /869.935^C264m

FFLCH-LE /869.935^C264m^e.2

Corrêa, Viriato 1883-. O país do pau de tinta; cronicas históricas da Terra do pau-Brasil

FFLCH-LE /869.985^C846p

Peregrino Júnior, João 1898-. Doença e constituição de Machado de Assis

FFLCH-LE /869.9341^ex.1^m1291pe

Setúbal, Paulo 1893-1937. O principe de Nassau romance historico

FFLCH-LE /869.935^S522p^5.ed

Assis, Machado de 1839-1908. Crítica litteraria

FFLCH-LE /869.9449^M129c/^ex.1

FFLCH-LE /869.9449^M129c/^ex.2

Vitor, Nestor. Os de hoje: figuras do movimentos modernista brasileiro

FFLCH-LE /869.9449^V686os

FFLCH-LE /869.909^V828d

Vellozo, Dario 1869-1937. Atlântida

FFLCH-GE /14^V441a^1938

Tavares Bastos, Aureliano Cândido 1839-1875. Cartas do Solitario

FFLCH-FI /981^B327c

Franco, Cid. Procura de cristo

FFLCH-HI /869.1^F825p

Fontes, Martins 1884-1937. Nos Jardins De Augusto Comte (Livro Posthumo)

FFLCH-FI /869^F682j

Leite, Serafim. História da Companhia de Jesus no Brasil

FFLCH-LE /255.53^L533h^v.1

Almeida, Guilherme de 1890-1969. Acaso; versos de todo tempo

FFLCH-LE /869.915^A447a^1938..

Mendes, Murilo 1901-1975. Metamorfoses; [II] Candido Portinari, Tomas Santa Rosa Junior FFLCH-LE /869.915^M492me.. 
Lessa, Origenes. Feijao e o sonho

FFLCH-LE /869.935^L632f^1938

Ramos, Graciliano 1892-1953. Vidas secas

FFLCH-LE /869.935^R143vi

Leite, Aureliano 1886-. Amador Bueno, o aclamado romance histórico

FFLCH-HI /869^L533a

Fontes, Martins 1884-1937. Nos Jardins De Augusto Comte (Livro Posthumo)

FFLCH-LE /869.9149^M343nj

Dutra, Osorio. O genio poetico de Martins Fontes

FFLCH-LE /869.9149^M3431d

Azevedo, Aluisio. Filomena borges

FFLCH-LE /869.9345^A986f^3.ed

Azevedo, Aluizio 1857-1913. O Mulato

FFLCH-LE /869.9345^A986mu^10.ed

Azevedo, Aluizio 1857-1913. O homem

FFLCH-LE /869.9345^A986h^8.ed

Azevedo, Aluísio 1857-1913. Livro de uma sogra

FFLCH-LE /869.9345^A986Li^7.ed.

França, Serafim. Barra Velha contos e lendas

FFLCH-LE /869.935^F883b

Bloem, Ruy. O primeiro romance brasileiro (retificação de um erro da história literária do Brasil)

FFLCH-LE /869.909^B612p

Mota, Leonardo 1891-1948. A "Padaria Espiritual"

FFLCH-LE /869.909^M871p

Fagundes, Ligia. Porão e sobrado, contos

FFLCH-LE /OBRA ESP.^T274

\section{9}

Verissimo, Erico. Viagem à aurora do mundo; ilustraçoes de Ernst Zeuner

FFLCH-GE /14^V517v^1939

FFLCH-HI /CE^5314

FFLCH-LE /869.935^V6190^v.8^1960

Ribeiro Couto, Rui. Cancioneiro de d afonso

FFLCH-LE /869.915^R368can..

Almeida, Prisciliana Duarte de. Vetiver poesias de vários tempos

FFLCH-LE /869.915^A45v

Maul, Carlos 1888-. Casimiro de Abreu, poeta do amor FFLCH-LE /869.9137^a1451ma.. 
Almeida, Serafim Vieira de. Anthologia de poetas sergipanos *

FFLCH-LE /869.9108^A451a

Bezerra de Freitas, José 1896-. História da literatura brasileira; para o curso complementar FFLCH-LE /869.909^F932h^e.1

Lins, Ivan Monteiro de Barros 1904-. Idade Media A Cavalaria E As Cruzadas

FFLCH-FI /940.18^L759i

FFLCH-LE /869.904^L731i

Fornari, Ernani 1899-1964. Iaia' Boneca; comédia em 4 atos Ilustrações de Hipólito Collombo FFLCH-LE /869.925^F824i

Tavares, Odorico. A sombra do mundo

FFLCH-LE /869.915^T231s

Barroso, Gustavo 1888-1959. O livro dos enforcados

FFLCH-LE /869.935^B285I

Pontes, Eloi. Vida contraditoria de machado de assis

FFLCH-LE /869.9341^m1291po

Queiroz, Dinah Silveira de 1911-. Floradas na serra romance FFLCH-LE /869.935^Q43f

Rêgo, José Lins do 1901-1957. Riacho Doce; romance. Capa de Santa Rosa

FFLCH-LE /869.935^R267r

Carvalho, José Cândido de Melo 1914-. Olha para o ceu, frederico

FFLCH-LE /869.935^C3240

Carvalho, Tito. Bulha d'arroio paginas serrano-catharinenses

FFLCH-LE /869.935^Ca329b

Faria, Octavio de.Caminhos da vida (mundos mortos-II). tragedia burguesa II

FFLCH-LE /869.935^F235c^v.1

FFLCH-LE $/ 869.935^{\wedge} \mathrm{F} 235 \mathrm{c}^{\wedge} \mathrm{V} .2$

Couto, Ruy Ribeiro 1898-. Cabocla; romance

FFLCH-LE /869.935^R368c^2.ed

Amado, Genolino. Um olhar sobre a vida (ensaios) Capa de Santa Rosa FFLCH-LE /869.945^Am494u^e.1

Magalhães, Basílio de 1874-. Folclore no brasil com uma coletanea de 81 contos populares FFLCH-FI /398.30981^M188f

Marques Pereira, Nuno 1652-1718. Compêndio narrativo do peregrino da América FFLCH-FI /869.1^P436c^v.1

Queiroz, Wenceslau de 1865-1921. Rezas do diabo

FFLCH-LE /869.9149^Q48r

Aranha, Graça 1868-1931. Chanaan

FFLCH-HI /CE^145 
FFLCH-LE /869.9348^G753c^8.ed

Campos, Flavio Seabra Pires de. Planalto

FFLCH-HI /CE^907

Ricardo, Cassiano. Academia e a poesia moderna

FFLCH-LE /869.945^R376ac

Licoes de Ruy

FFLCH-HI /869.908^D541I

Gomes da Silva, Francisco 1791-1852. Memórias ; prefácio e anotações de Noronha Santos

FFLCH-LE $1920^{\wedge}$ S58m

Santos, José Carlos dos. Contos regionais

FFLCH-LE /869.935^S235c

Genofre, Edmondo Mourao. Homens e livros

FFLCH-LE /869.909^G293h

Tavares, Adelmar. Caminho enluarado

FFLCH-LE /869.915^T228c^3.ed..

Carneiro, Cecilio J. Memorias de cinco; o drama dos medicos novos

FFLCH-LE /869.935^C288m

Azevedo, Aluísio 1857-1913. O esqueleto (mistério da casa de Bragança)

FFLCH-LE /869.9345^A986e^2.ed

Martins, Jackson de Figueiredo. Correspondencia

FFLCH-LE /869.962^M344c

Freire, Cavalheiro. Primicias

FFLCH-LE /869.9149^F933p

Barroso, Gustavo. A guerra do Vidéo; contos e episodios da campanha da Cisplatina 1825 a 1828 FFLCH-LE /869.935^B285g^1939..

Azevedo, Aluísio. Girandola de amores (publicado com o título Mistério da Tijuca, litteratura dos vinte annos) FFLCH-LE /869.9345^A986g^4.ed.

\section{0}

Sodré, Nelson Werneck 1911-. Historia da literatura brasileira; seus fundamentos economicos FFLCH-LE /869.909^S663h^2.ed^ex.1

Novas cartas jesuíticas (de Nóbrega a Vieira) Serafim Leite

FFLCH-LE /869.962^L55n 
Pereira, Lafayette Rodrigues. Vindiciae; o Sr. Sylvio Romero, critico e philosopho FFLCH-LE /869.9341^M1291p^3.ed...

Barros, Leônidas de. Ascensão poesias

FFLCH-LE /869.915^B279a..

Abreu, Casimiro José Marques de 1839-1860. Obras de Casimiro de Abreu

FFLCH-LE /869.9137^A145o

Bandeira, Manuel 1886-1968. Antologia dos poetas brasileiros da fase romântica FFLCH-LE /869.9108^B166ar^2.ed

Quintana, Mario. A rua dos cataventos

FFLCH-LE /869.915^Q67r

Silveira, Tasso da 1895-1968. O canto absoluto poemas seguido de Alegria do mundo FFLCH-LE /869.915^S591c

Peixoto, Afranio. Panorama da literatura brasileira 1500-1940

FFLCH-LE /869.909^P43p^1940

Bandeira, Manuel 1886-1968. Poesias completas FFLCH-LE /869.915^B166p^2.ed..

Schmidt, Augusto Frederico. Estrella solitaria

FFLCH-LE /869.915^Sch376e

Cruz, Eddy Dias da 1907-1973. Rua Alegre, 12 [por] Marques Rebelo [pseud.]

FFLCH-LE /869.925^M32r

Azevedo, Aluísio 1857-1913. O Coruja

FFLCH-LE /869.9345^A986cor^6.ed

Azevedo, Aluísio 1857-1913. A mortalha de Alzira

FFLCH-LE /869.9345^A986mo^6.ed

Asfora, Perminio. Sape

FFLCH-LE /869.935^A848s

Azambuja, Darcy 1903-1970. Romance antigo

FFLCH-LE /869.935^A984r

Alves, Oswaldo 1912-. Um homem dentro do mundo (romance)

FFLCH-LE /869.935^A482u..

Jorge, J G de Araujo. Besouro contra a vidraca...

FFLCH-LE /869.935^A689u

Lima, Jorge de 1893-1953. O anjo

FFLCH-LE /869.935^L698a^2.ed

Menotti del Picchia 1892-. Salomé romance

FFLCH-LE /869.935^M517s^1940 
Couto, Rui Ribeiro 1898-1963. Largo da Matriz, e outras histórias

FFLCH-LE /869.935^R368la^1940

Couto, Rui Ribeiro 1898-1963. Prima Belinha, romance FFLCH-LE /869.935^R368pr^1940..

Coutinho, Afrânio. A filosofia de Machado de Assís ..

FFLCH-LE /869.9441^M1291co^1940^e.1

Andrade, Oswald de. Marco zero a revolucao melancolica FFLCH-LE /869.935^An568mz^v.1

Sousa, de 1896-1945. Um clarão rasgou o céu romance

FFLCH-LE /869.935^S697u

Ramos, Arthur. Negro brasileiro

FFLCH-FI /264.1^R175n^v.1^2.ed.

Brasil. Me.Lucilio de albuquerque exposicao retrospectiva FFLCH-FI /759.981^B823I.

Silveira, Joel. Roteiro de Margarida, contos FFLCH-LE /869.935^S588r

Monteiro, Adolfo Casais 1908-1972. Sôbre o romance contemporâneo FFLCH-LE /801.953^M774s

Nunes, Arnaldo. Laguna

FFLCH-HI /CE^3777..

Santos, Thomaz Vieira dos. Ressonancias

FFLCH-LE /869.935^S233r

Oliveira, Nelson Tabajara de. Da taba ao arranha-ceu a encruzilhada nacional FFLCH-LE /869.904^O45d

Silva, Oscar Jose de Placido E. Ódios da cidade

FFLCH-LE /869.935^S5810

Fontes, Hermes. Poesias escolhidas

FFLCH-LE /869.915^F766p

Moreira, Albertino. Pouso da estrada

FFLCH-LE /869.935^M836p..

Sette, Mario. Anquinhas e bernardas

FFLCH-LE /869.985^S519a

Azevedo, Aluísio 1857-1913. Casa de pensão

FFLCH-LE /869.9345^A986c^9.ed.

\section{1}


Carvajal, Gaspar de 1504-1584. Descobrimentos do rio das Amazonas traduzidos e anotados por C. de Melo-Leitão

FFLCH-FI /918.11^C331d

FFLCH-GE $/ 918.11^{\wedge} \mathrm{C} 331 \mathrm{~d}^{\wedge} \mathrm{e} .2$

Figueiredo, Fidelino de Sousa 1888-1957. Aristarchos quatro conferencias sobre methodología da critica litteraria no Departamento municipal de cultura de São Paulo, Brasil Fidelino de Sousa Figueiredo

FFLCH-LE /869.47^F49a

Dantas, Mercedes. O nacionalismo de Castro Alves

FFLCH-LE /869.9145^C351d

Mendes, Murilo 1901-1975. O visionario poemas (1930/33)

FFLCH-LE /869.915^M492v^ex.1

Jorge, J G de Araujo. Cantico do homem prisioneiro] e cantico dos canticos] poemas

FFLCH-LE /869.915^J71ca

Rodrigues de Mello, José 1704-1783. Geórgicas brasileiras (cantos sôbre coisas rusticas do Brasil) (1781) Versão em linguagem de João Gualberto Ferreira dos Santos Reis. Biografias e notas de Regina Pirajá da Silva

FFLCH-HI /CE^99

FFLCH-LE /869.9114^A516g

Andrade, Mário de 1893-1945. Poesias

FFLCH-LE /869.915^A568po

Vianna Filho, Oduvaldo. Teatro

FFLCH-LE /869.925^Vo671t

Fornari, Ernani 1899-1964. Sinhá moça chorou .. peça em 6 quadros .. Ilustrações de F. Acquarone FFLCH-LE /869.925^F824s

Guimaraes, Bernardo. Mauricio ou paulistas em S. Joao D'el Rei

FFLCH-LE /869.9333^G976m².ed

Abreu, Adriano de. Dias de maio romance, ficcao e costumes

FFLCH-LE /869.935^Aa145d

Peixoto, Afrânio 1876-1947. Bugrinha

FFLCH-LE /869.935^P43b^4.ed

Queiroz, Dinah Silveira de. Sereia verde contos

FFLCH-LE /869.935^Q43s

Rêgo, José Lins do 1901-1957. Água-mãe

FFLCH-LE /869.935^R267a

Campos, Humberto de 1886-1934. Os párias (crônicas)

FFLCH-LE /869.985^C212^v.4^1941

Machado, Alcântara 1875-1941. Alocucões acadêmicas

FFLCH-LE /869.955^A319a

Silveira, Tasso da 1895-1968. Só tu voltaste? romance 
FFLCH-LE /869.935^S591s

Vasconcellos, Salomão de 1877-1930. Ataíde, pintor mineiro do século XVIII FFLCH-FI /759.981^V331a

Gama, Jose Basilio da. Uruguai

FFLCH-FI /869^G184u

Guimarães, José de Freitas. Ainda e sempre versos

FFLCH-LE /869.915^G976a

Tenorio d'Albuquerque, Acir 1899-. Atentados contra o Brasil por A. Tenorio d'Albuquerque. Com um vibrante prefácio do general Meira de Vasconcellos

FFLCH-HI /869.904^D136a..

Carvalho, Valter Campos de. Banda forra

FFLCH-LE /869.904^C329b..

Caiuby, Amando.Sapezais e tigueras contos sertanejos

FFLCH-LE /869.935^C138s

Guimaraes, Vicente. Os bichos eram diferentes

FFLCH-HI /CE^2370

Leite, Armando Mas. Itinerario

FFLCH-HI /CE^3015

Frieiro, Eduardo. Os livros nossos amigos

FFLCH-LE /869.945^F947I..

Leite, Augusto da Costa. Saudades e lembrancas do caraca

FFLCH-LE /869.935^La55s

Domingues, Octavio. A concepcao hereditaria no d. Casmurro

FFLCH-LE /869.9341^D718c

\section{2}

Egas, Sebastiana. Rosa mystica, coletanea de poesias

FFLCH-LE /869.9108^E26r

Figueiredo, Fidelino de Sousa 1888-1957. Antero quatro conferências promovidas pelo Departamento municipal de cultura de São Paulo

FFLCH-LE /869.163^Q511fi

Pereira Filho, Genésio. Um tema e três obras em tôrno de "Rebecca", "A Sucessora" e "Encarnação"

FFLCH-LE /801.93^P491t

Melo, A. L. Nobre de. Augusto dos Anjos e as origens de sua arte poética 
FFLCH-LE /869.9148^A6191n

Carvalho, Affonso de 1897-1953. Bilac: o homem, o poeta e o patriota FFLCH-LE /869.9148^B4921c

Andrade, Mario de. Movimento modernista

FFLCH-LE $/ 869.904^{\wedge} \mathrm{A} 568 \mathrm{~m}^{\wedge} \mathrm{ex} .1$

Castro, Aloysio de 1881-. Christus

FFLCH-LE /869.915^C35c

Schmidt, Augusto Frederico. Mar desconhecido

FFLCH-LE /869.915^SCH376po

Peixoto, Afranio. Sinhazinha

FFLCH-LE /869.935^P43s^2.ed

Queiroz, Dinah Silveira de 1911-. Cuando la sierra florece

FFLCH-LE /869.935^Q43ce

Queiroz, Rachel de. O quinze romance

FFLCH-LE /869.935^Q47q^3.ed

Freyre, Gilberto. Ingleses Prefacio de José Lins do Rego

FFLCH-LE /869.945^F943i

Maya, Alcides 1878-1944. Machado de Assis (Algumas notas sobre o "humour")

FFLCH-LE /869.9341^2.ed^m1291may..

Faria, Octavio de. Lodo das ruas (os paivas-I) romance. tragedia burguesa III FFLCH-LE $/\left.869.935^{\wedge} F 235\right|^{\wedge} \vee .1$

Lima, Rossini Tavares de. Gregorio de matos, o boca de inferno FFLCH-LE /869.9711^M3911I

Peixoto, Afrânio 1876-1947. Viagem sentimental; kodaks e postais

FFLCH-LE /869.985^P43v^2.ed

Barros, Francisca de. Nemigalha

FFLCH-LE /869.985^B277n

Machado, Dyonelio 1895-. Louco do cati

FFLCH-LE /869.935^M13I

Braga, Theodoro. Artistas pintores no brasil

FFLCH-FI /759.981^B813a

Arinos de Melo Franco, Afonso. Dirceu e Marília drama lirico em três atos llustrações de Luiz Jardim

FFLCH-LE /869.925^F894d^1942..

Rebelo, Marques 1907-1973. Stela me abriu a porta

FFLCH-LE /869.935^M32s

Leite, Ascendino. Notas provincianas .. 
FFLCH-LE /869.945^L55n

Milliet, Sergio 1898-. Fora de forma (arte e literatura)

FFLCH-LE /869.945^M593f..

Carpeaux, Otto Maria 1900-1978. Cinza do purgatorio

FFLCH-LE /801^C298c

Marques, Cicero. Tempos passados...

FFLCH-HI /981.6^M357t

Ferreira, Jurandyr Pires. Derrocada dos preconceitos

FFLCH-HI /869.985^F383d

Peixoto, Afrânio 1876-1947. Pepitas, novos ensaios de critica e de historia

FFLCH-LE /869.945^P43p

\section{3}

Couto, Rui Ribeiro 1898-1963. Cancioneiro do ausente

FFLCH-LE /869.915^R368ca

Accioli, Joao. Olho d'agua poesia

FFLCH-LE /869.915^A1550^2.ed

Barreto, Tobias 1839-1889. O pensamento vivo de Tobias Barreto apresentado por Hermes Lima FFLCH-HI /CE^3100

FFLCH-LE /869.9142^B2641l

Silva Alvarenga, Manuel Ignacio da 1749-1814. Glaura poemas eróticos; prefácio de Afonso Arinos de Melo Franco

FFLCH-LE /869.9126^A47g

Pereira, Lúcia Miguel 1901-1959. Vida de goncalves dias, contendo o diario inedito da viagem de goncalves dias ao rio negro

FFLCH-LE /869.9133^G6251m

Obras-primas da lírica brasileira seleção de Manuel Baneira ; notas de Edgard Cavalheiro

FFLCH-LE /869.9108^B166o

Bastide, Roger 1898-. A poesia afro-brasileira

FFLCH-FI /301.2^B324po

FFLCH-LE /869.9109^B324po

Mennucci, Sud. Machado de Assis conferencia

FFLCH-LE /869.9341^M1291ms

Sodré, Nelson Werneck 1911-. Síntese do desenvolvimento literário no Brasil

FFLCH-LE /869.909^S663s^e.1

Azevedo, Aluisio. Filomena borges (philomena borges) Aluisio Azevedo ; [Pref] M Nogueira Silva FFLCH-LE /869.9345^A986f^4.ed..

Azevedo, Aluizio 1857-1913. Demônios

FFLCH-LE /869.9345^A986d^5.ed 
Azevedo, Aluizio 1857-1913. Uma lágrima de mulher romance original FFLCH-LE /869.9345^A986La^5.ed

Alphonsus, João 1901-1944. Eis a noite! contos \& novelas

FFLCH-LE /869.935^A651e.

Batini, Tito. Entre o chão e as estrêlas... romance

FFLCH-LE /869.935^B335en

Cardoso, Lucio. Dias perdidos romance

FFLCH-LE /869.935^C264d

Azevedo, Aluísio 1857-1913. El conventillo

FFLCH-LE /869.9345^A986ce

Queiroz, Rachel de 1910-. As três Marias (romance)

FFLCH-LE /869.935^Q47t^2.ed

FFLCH-LE /869.935^Q47t^2.ed^ex.2

Rêgo, José Lins do 1901-1957. Doidinho romance

FFLCH-LE /869.935^R267d^4.ed..

Rêgo, José Lins do 1901-1957. Pureza: romance

FFLCH-LE /869.935^R267p^3.ed

Silveira, Tasso da. Silencio

FFLCH-LE /869.935^S591si

Moog, Clodomir Vianna 1906-. Um rio imita o Reno

FFLCH-LE /869.935^M81r^4.ed^e.1

Vieira, Jose Geraldo. Quadragesima porta romance FFLCH-LE /869.935^V715q

Alves, Constancio Antonio. Santo antonio

FFLCH-LE /869.985^A478s

Vieira, Hermes. Vicente de Carvalho o sabiá da Ilha do Sol : biocrítica FFLCH-LE /869.9149^C3291vh^2.ed.

Ramos, Arthur. O negro brasileiro ethnographia religiosa e phychanalyse FFLCH-FI /264.1^R175ne

Barbosa, Rui 1849-1923.Discursos parlamentares camara dos deputados FFLCH-HI /OBRA ESP.^890^v.6^t.1

Anselmo, Manuel 1911-.Família literária luso-brasileira (ensaios de literatura e estética) FFLCH-LE /869.09^A627f

FFLCH-LE $/ 869.09^{\wedge} A 627 f^{\wedge} \mathrm{e} .2$

Lacerda, Carlos. O rio [peça em três atos]

FFLCH-LE /869.925^L135r 
Meyer, Augusto 1902-1970. Prosa dos pagos

FFLCH-LE /398.0981^M559pr^v.3^ex.1

Andrade, Oswald de 1890-1954. Marco Zero ..

FFLCH-LE /869.935^An568mz^v.1

Barbosa de Oliveira, Albino José 1809-1889. Memórias de um magistrado do império revistas e anotadas por Américo Jacobina Lacombe

FFLCH-HI /981^B823^v.231

Alcântara Machado, José de 1875-1941. Vida e morte do bandeirante; introdução de Sérgio Milliet, desenhos de J. Wasth Rodrigues

FFLCH-FI /981.61^M149vi

FFLCH-HI /981.03^A347v

Romero, Sílvio 1851-1914. História da literatura brasileira

FFLCH-HI /869.09^R763h^v.1

Carvalho, Ronald de 1893-1935. Pequena Historia De La Literatura Brasilena

FFLCH-HI /869^C331p

Lapa, Rodrigues. Quadro da cronica de D.João I

FFLCH-HI /869^L864q

Homenagem a Graciliano Ramos [Augusto Frederico Schmidt ... [et al.]]

FFLCH-LE /869.935^R1431

Haddad, Jamil Almansur. Poemas oracoes roxas, novas oracoes negras, oracoes vermelhas FFLCH-LE /869.915^H144p

Dutra, Lia Correa. Navio sem porto

FFLCH-LE /869.935^D975n..

Obras completas de Álvares de Azevedo edição rigorosamente revista, com um prefácio de Edgard Cavalheiro

FFLCH-LE /869.9134^A4720^v. 2

Dutra, Osorio. Mundo sem alma

FFLCH-LE /869.915^D976m..

Lobato, José Bento Monteiro 1882-1948. Urupês, outros contos e coisas; organizada e prefaciada por Artur Neves

FFLCH-LE /869.935^M778u

Dupre, Maria Jose Fleury Monteiro. Eramos seis romance

FFLCH-LE /869.935^D947e^3.ed.

Gusmão, Alexandre de 1695-1753.Obras cartas poesias, teatro

FFLCH-LE /869.98^G990^1943

Homenagem a Guilherme de Almeida

FFLCH-LE /869.915^A4471h

\section{4}


Lima, Silvio. Ensaio sobre a essencia do ensaio

FFLCH-LE /801.954^L71e^1944

Rabello, Sylvio. Itinerario de Sylvio Romero Ed. ilustrada FFLCH-LE /869.909^R114i

Queiroz, Dinah Silveira de 1911-. Floradas na serra romance

FFLCH-LE /869.935^Q43f^5.ed

Almeida, Guilherme de. Tempo, (1914-1944) Prefácio de Jamil Almansur Haddad. Ilustrações de Quirino

FFLCH-LE /869.915^A447te..

Peixoto, Afranio. Trovas brasileiras (populares popularizadas)

FFLCH-LE /869.915^P43t^2.ed

Ivo, Lêdo. As imaginações [poesia]

FFLCH-LE /869.915^193i

Bandeira, Manuel 1886-1968. Poesías completas

FFLCH-LE /869.915^B166q^3.ed

Azevedo, Aluísio 1857-1913. O esqueleto (mistério da casa de Bragança)

FFLCH-LE /869.9345^A986e^3.ed.

Azevedo, Aluisio. Touro negro cronicas e epistolario Aluisio Azevedo ; [Pref] M Nogueira da Silva FFLCH-LE /869.9345^A986t^2.ed

Avila, Aristides. Juizo final alem de outros casos de menor gravidade : contos

FFLCH-LE /869.935^Av971j..

Machado, A. de Alcântara 1901-1935.Bras, bexiga e barra funda e laranja da china *

FFLCH-LE /869.935^A319b^1944

Amado, Jorge 1912-. São Jorge dos Ilhéus

FFLCH-LE /869.935^A494s^2.ed^ex.1

FFLCH-LE /869.935^A494s^2.ed^ex.2

Andrade, Mário de 1893-1945. Amar, verbo intransitivo [idílio]

FFLCH-LE /869.935^A568a

Rêgo, José Lins do 1901-1957. Fogo morto; préfacio de Otto Maria Carpeaux ; apêndice de Alvaro Lins

FFLCH-LE /869.935^R267f^2.ed^e.1

Madeira, Marcos Almir. Ironia de machado de assis e outros temas

FFLCH-LE /869.9341^m1291mad

Couto, Rui Ribeiro 1898-1963. Isaura

FFLCH-LE /869.935^R368i^1944

Freire, Luiz José Junqueira 1832-1855. Poesias completas de Junqueira Freire .. Ed. rigorosamente revista, com um estudo de Roberto Alvim Corrêa

FFLCH-LE /869.9135^J94p^v.1-2 
Ferreira, Tito Lívio. História e lenda (1.a série)

FFLCH-GE /3^F383h

FFLCH-HI /A40.50^F383h^e.2

FFLCH-HI /CE^1916

FFLCH-HI /CE^1917^e.2

Moreira, Thiers Martins. Camões e Fernão Lopes

FFLCH-FI /869^M838c..

Sant'Anna, Nuto. Fábrica

FFLCH-LE /869.935^S223f

Lobato, José Bento Monteiro. A barca de gleyre; quarenta anos de correspondencia literaria entre Monteiro Lobato e Godofredo Rangel; com um prefácio de Edgard Cavalheiro

FFLCH-LE /869.965^M778b^1944

Freire, Gilberto de Melo. Perfil de euclydes e outros perfis

FFLCH-LE /869.945^F943p^ex.1

Ronal, Maia. Segrêdo

FFLCH-LE /869.915^R675s

Rodrigues, Nelson. Vestido de noiva. A mulher sem pecado

FFLCH-LE /869.925^R614v^1944

Machado, Dyonelio 1895-. Os ratos ..

FFLCH-LE /869.935^M13r^2.ed

Silveira, Helena. A humilde espera contos

FFLCH-LE /869.935^S588h. .

Andrade, Carlos Drummond de 1902-1987.Confissões de Minas FFLCH-LE /869.985^D859c^ex.1

Caldas Barbosa, Domingos d. 1800. Viola de Lereno, [Pref.] de Francisco de Assis Barbosa FFLCH-LE /869.9129^B196v^v.1..

Vellinho, Moysés. Letras da província

FFLCH-LE /869.909^V55/^e.1

FFLCH-LE /869.909^V55/^e.2

Marques, Xavier. Ensaios Pref. de Clementino Fraga

FFLCH-LE /869.904^M317 $\mathrm{e}^{\wedge} \mathrm{V} .2$

FFLCH-LE /869.945^M317e^e.2

Bilac, Olavo. Tratado de versificacao a poesia no brasil ; a metrica, generos literarios FFLCH-LE /801.951^B492t^8.ed...

Lobato, Monteiro. Reforma da natureza e o espanto das gentes

FFLCH-HI /CE^3615

Morley, Helena. Minha vida de menina cadernos de uma menina provinciana nos fins do seculo xix FFLCH-LE /869.98^M853m^2.ed... 
Jorge, Salomao Pedro. Tendas do meu deserto

FFLCH-LE /869.915^J71t..

Martins, Ivan Pedro de. Fronteira agreste

FFLCH-LE /869.935^M343f..

Machado, Aníbal Monteiro 1894-1964. Vila feliz

FFLCH-LE /869.935^M129v

Vieira, Jose. Vida e aventura de pedro malasarte romance

FFLCH-LE /869.9349^V715v

Marchini, Marina Stella Quirino. Sursum corda

FFLCH-LE /869.915^M265s

Lima, Jorge de 1893-1953. Anchieta

FFLCH-LE /869.911^A5541Lj^1944..

\section{5}

Amado, Jorge. Bahia de todos os santos guia das ruas e dos misterios da cidade de salvador FFLCH-GE $/ 629^{\wedge}$ A481b^1945

Camargo, Joracy 1898-1973. Anastácio trági-comédia em 3 atos, divididos em 6 quadros FFLCH-LE /869.925^C178a^3.ed

Bento, Almir Rodrigues. Sol poemas; [Intr] Paulo Menotti Del Picchia

FFLCH-LE /869.915^B42s^2.ed

Campos, Humberto de. Poesias completas, 1903-1931

FFLCH-LE /869.985^C212^v.1^2.ed...

Malta Cardozo Neto, Francisco. Castro Alves

FFLCH-LE /869.9145^C351ca

Martins, Mario R. Evolucao Da Literatura Brasileira

FFLCH-LE /869.909^M344e^v.1^e.1

Mendes, Murilo. Mundo enigma (1942) Os quatro elementos (1935)

FFLCH-LE /869.915^M492mu..

Andrade, Oswald de. Poesias reunidas de oswald de andrade FFLCH-LE /869.915^An568p

Camargo, Joracy. Deus Ihe pague... Comedia em 3 atos divididos em 9 quadros FFLCH-LE /869.925^C178d^8.ed

Fornari, Ernani 1899-1964. Nada [peça em 4 atos] FFLCH-LE /869.925^F824n^2.ed

Andrade, Carlos Drummond de. Rosa do povo poesia 
FFLCH-LE /869.915^D859ro..

Cabral de Melo Neto, João. O engenheiro

FFLCH-LE /869.915^M485en..

Mendes, Murilo. O discípulo de Emaús

FFLCH-LE /869.915^M492d..

Anjos, Cyro dos. Abdias - romance - Capa de Santa Rosa

FFLCH-LE /869.935^A619a

Campos, Humberto de. O monstro, e outros contos

FFLCH-LE $/ 869.935^{\wedge} \mathrm{C} 212 \mathrm{~m}^{\wedge} 2$.ed

Rego, José Lins do. Poesia e vida

FFLCH-LE /869.945^R267p

Ramos, Graciliano. Infância ..

FFLCH-LE /869.935^R143i

Campos, Humberto de. Contrastes [cronicas]

FFLCH-LE /869.985^C212^v.13^2.ed.

Campos, Humberto de. Mealheiro de Agripa [crônicas]

FFLCH-LE $/ 869.985^{\wedge} \mathrm{C} 212^{\wedge} \mathrm{v} .3^{\wedge} 2$.ed

Campos, Humberto de. Notas de um diarista 2. série. Obra póstuma

FFLCH-LE $/ 869.985^{\wedge} \mathrm{C} 212^{\wedge} \mathrm{v} .9^{\wedge} 2$.ed

Campos, Humberto de. Perfis

FFLCH-LE /869.985^C212^v.14^2.ed.

Campos, Humberto de. Reminiscencias... Humberto de Campos

FFLCH-LE /869.985^C212^v.11^2.ed.

Castro, Aloysio de. Caixinha de enfeites

FFLCH-LE /869.985^C35c

Viana Filho, Luís. A verdade na biografia

FFLCH-LE /869.945^V667v

Lima, Alceu Amoroso. O crítico literário

FFLCH-LE /869.945^L696c^e.1

FFLCH-LE /869.945^L696c^e.2

Campos, Humberto de. O Brasil anedótico; frases históricas que resumem a crônica do Brasilcolônia, do Brasil-império e do Brasil-república

FFLCH-LE $/ 869.985^{\wedge} \mathrm{C} 212^{\wedge}$ v. $27^{\wedge} 2$.ed.

Lessa, Origenes. Ok america cartas de Nova York

FFLCH-LE /869.985^L632ok..

Bastide, Roger 1898-. Imagens do nordeste místico em branco e prêto FFLCH-GE /621.09^B326i^1945 
Nina Rodrigues, Raymundo. Os africanos no Brasil

FFLCH-FI /301.451^R696a^e.1

Marianno, José. Antônio Francisco Lisboa

FFLCH-FI /730^M333a

Leite, Manoel Cerqueira. Do fato literario, sob o ponto de vista funcional

FFLCH-FI /869^L533d

Dutra, Osorio. Emoção

FFLCH-LE /869.915^D976e

Silveira, Joel. Lua

FFLCH-LE /869.935^S588I

Silveira, Joel. Grã-finos em São Paulo e outras notícias do Brasil ; reportagens...

FFLCH-LE /869.985^S588g

Andrade, João Cunha. Árvore da montanha [poesias]

FFLCH-HI /CE^123

Orta, Teresa Margarida da Silva e b. Aventuras de Diófanes Pref. e estudo bibliográfico de Rui Bloem

FFLCH-LE /869.9329^H811a

Silveira, Valdomiro. Lereias histórias contadas por elles mesmos

FFLCH-LE /869.9349^S591l

Etnografia e lingua tupi-guarani - poesias tupis (sec xvi)

FFLCH-LE /898.3^E85

Sette, Mario. Barcas a vapor cenas do passado brasileiro.

FFLCH-HI /869.909^S495b

Campos, Antônio Sales. Origens e evolução dos temas da primeira geração de poetas românticos brasileiros

FFLCH-HI /869^C1980..

Campos, Humberto de. Critica primeira a quarta series

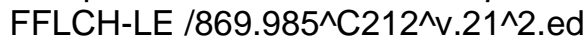

Chaves, Ovidio. Capricornius um dia tem mil seculos

FFLCH-LE /869.935^C439c..

Abreu, Jose M Casimiro de. Primaveras; [Intr] Afranio Peixoto

FFLCH-LE /869.9137^A145p^1945..

Fonseca, Gondin da. Histórias de João Mindinho contos de mágicos e de fadas FFLCH-HI /CE^1991

Campos, Humberto de. Antología da Academia Brasileira de Letras trinta anos de discursos academicos, 1897-1927

FFLCH-LE $/ 869.985^{\wedge} \mathrm{C} 212 \mathrm{a}^{\wedge} 1945$

Montalegre, Duarte de. Ensaio sobre o parnasianismo brasileiro, seguido de uma breve antologia FFLCH-LE /869.909^M763e.. 
Campos, Humberto de. Carvalhos e roseiras figuras políticas e literárias

FFLCH-LE /869.985^C212^v.20^2.ed.

Campos, Humberto de. Da seara de booz 1915-1916

FFLCH-LE $/ 869.985^{\wedge} \mathrm{C} 212^{\wedge} \mathrm{v} .2^{\wedge} 2$.ed

Campos, Humberto de. Destinos...

FFLCH-LE $/ 869.985^{\wedge} \mathrm{C} 212^{\wedge} v .7^{\wedge} 2 . e d$

Campos, Humberto de. Lagartas e libelulas

FFLCH-LE /869.985^C212^v.5^2.ed

Campos, Humberto de. Sepultando os meus mortos

FFLCH-LE $/ 869.985^{\wedge} \mathrm{C} 212^{\wedge} \mathrm{v} .8^{\wedge} 2$.ed

Campos, Humberto de. Um sonho de pobre

FFLCH-LE /869.985^C212^v.12^2.ed...

Campos, Humberto de. Últimas crônicas

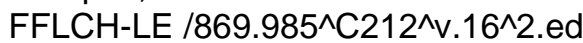

Campos, Humberto de. Poesias completas 1893-1931

FFLCH-LE /869.985^C212^v.1

Monteiro Lobato, Jose Bento. O presidente negro ou o choque das racas romance americano do ano 2228

FFLCH-LE /869.935^M778ch^1945

Pernetta, Emiliano. Poesias completas de emiliano pernetta

FFLCH-LE /869.9149^P531p

Amado, Jorge. Abc de Castro Alves

FFLCH-LE /869.935^A494a^3.ed^1945

Bloem, Ruy. Palmeiras no litoral (anotações à margem dos livros)

FFLCH-LE /869.909^B612pa 
UNIVERSIDADE DE SÃO PAULO

FFLCH

DEPARTAMENTO DE LETRAS ORIENTAIS

ANEXO III - FICHAMENTO DAS OBRAS 


\section{$\begin{array}{llll}\text { FICHA N }^{\circ} & 001 & \text { data } & 14 / 09 / 2002\end{array}$}

AUTOR: ANTONIO DE ALCÂNTARA MACHADO

TÍTULO DA OBRA: NOVELAS PAULISTANAS

EDIÇÃO:

LOCAL DE PUBLICAÇÃO: Rio de Janeiro

EDITORA: Ediouro/1999

DATA DA $1^{\text {a }}$ EDIÇÀO: 1928

PROSA ( $X$ ) POESIA ( )

PERSONAGEM: JUDIA $(X)$ ESTRANGEIRA $(X)$

REFERÊNCIAS: A PERSONAGENS OU PESSOAS JUDIAS ( $X$ )

A PERSONAGENS OU PESSOAS ESTRANGEIRAS $(X)$

REFERÊNCIAS: A CULTURA JUDAICA（）

A CULTURA ESTRANGEIRA $(X)$

REFERÊNCIAS: INTERTEXTUAIS（） TEXTUAIS（）

SE SIM, QUAIS?

\section{CARACTERÍSTICAS DA PERSONAGEM JUDIA:}

- NOME: Lázaro Salém e o "Turco" que morava na Rua Brigadeiro Tobias

- CARACTERÍSTICAS FÍSICAS: não são apresentadas, apenas o autor faz referências ao modo de agir descontraído do personagem Lázaro Salém, um balconista de loja no bairro do Bom Retiro. Quanto ao Turco, há apenas a característica física de que usava costeletas e era identificado pelo autor como um perigo em suma( face a filha do personagem Dagoberto estar apaixonada por ele).

\section{A REFERÊNCIA APARECE:}

- CAPÍTULO(s) "O ingênuo Dagoberto(seu Dagoberto Piedade)"

- PÁGINA(s) 116, 117 e 123

\section{OBSERVAÇÕES ESPECÍFICAS:}

O conto faz parte originalmente do livro Laranja da China, que nesta edição está reunido com outras obras do autor. Há apenas dois personagens que apresentam características que dão a entender que estes são judeus, mas apenas com um olhar mais atento é que se percebe isto, pois o autor não dá qualquer pista neste sentido. A maior parte dos personagens são italianos, espanhóis, portugueses, quase todos imigrantes. Há também uma mistura "macarrônica" da língua portuguesa com a língua italiana. 


$\begin{array}{llll}\text { FICHA N }^{\circ} & 002 & \text { data } & 19 / 09 / 2002\end{array}$

AUTOR: HUMBERTO DE CAMPOS

TÍTULO DA OBRA: MEMÓRIAS: $1^{\circ}$ PARTE 1886-1900

EDIÇÃO:

LOCAL DE PUBLICAÇÃO: São Paulo

EDITORA: W. M. Jackson Inc./1954

DATA DA $1^{\text {a }}$ EDIÇÀO:

PROSA ( $X$ ) POESIA ( )

PERSONAGEM: JUDIA ( $X$ ) ESTRANGEIRA（）

REFERÊNCIAS: A PERSONAGENS OU PESSOAS JUDIAS ( $X$ )

A PERSONAGENS OU PESSOAS ESTRANGEIRAS ( )

REFERÊNCIAS: A CULTURA JUDAICA ( $X$ )

A CULTURA ESTRANGEIRA（）

REFERÊNCIAS: INTERTEXTUAIS（） TEXTUAIS（）

SE SIM, QUAIS?

\section{CARACTERÍSTICAS DA PERSONAGEM JUDIA:}

- NOME: Leoncio de Oliveira - Alfaiate

- CARACTERÍSTICAS FÍSICAS: 55 anos, alto, magro, moreno, usava barba grisalha, nariz aquilino, olhos próximos um do outro, falava devagar e baixo, movia-se com lentidão, corcunda, não conversava muito, nem tinha amigos e usava quipá.

\section{A REFERÊNCIA APARECE:}

- CAPÍTULO(s) XXXVII - Linha, Agulha e Dedal

- PÁGINA(s) 217, 268, 269, 270, 271, 272 e 273

\section{OBSERVAÇÕES ESPECÍFICAS:}

Na página 217 há uma referência à cultura judaica, onde o autor menciona a palavra sinagoga. Nas demais páginas citadas trata do personagem Leoncio de Oliveira, que apresenta características muito próximas dos esteriótipos utilizados na época. 
AUTOR: GILBERTO FREYRE

TÍTULO DA OBRA: MANIFESTO REGIONALISTA

EDIÇÃO: $7^{\mathrm{a}}$ - revista e ampliada

LOCAL DE PUBLICAÇÃO: Recife

EDITORA: Massangana/1996

DATA DA 1ª EDIÇÀO: 1926 como artigos de jornal e 1952 no formato livro

PROSA ( $X$ ) POESIA ( )

PERSONAGEM: JUDIA（） ESTRANGEIRA（）

REFERÊNCIAS: A PERSONAGENS OU PESSOAS JUDIAS ( )

A PERSONAGENS OU PESSOAS ESTRANGEIRAS (X)

REFERÊNCIAS: A CULTURA JUDAICA (X)

A CULTURA ESTRANGEIRA $(X)$

REFERÊNCIAS: INTERTEXTUAIS（） TEXTUAIS（）

SE SIM, QUAIS?

CARACTERÍSTICAS DA PERSONAGEM JUDIA:

- NOME:

- CARACTERÍSTICAS FÍSICAS:

A REFERÊNCIA APARECE:

- CAPÍtUlo(s)

- PÁGINA(s) 60, 61, 62 e 72

OBSERVAÇÕES ESPECÍFICAS:

Escrito para o $1^{\circ}$ Congresso Brasileiro de Regionalismo, a obra insere todos os tipos humanos/religiosos na formação e construção do povo brasileiro. O autor trata da profusão de povos que originou o brasileiro de maneira uniforme, todos como agentes ativos na nossa formação, nenhum tipo aparece como melhor ou pior.

Também merece destaque o fato de Freyre resgatar o judeu na formação da cultura e do povo brasileiro, até então ausente da história oficial. 
AUTOR: GILBERTO FREYRE

TÍTULO DA OBRA: OLINDA: $2^{\circ}$ GUIA PRÁTICO, HISTÓRICO E SENTIMENTAL DE CIDADE BRASILEIRA

EDIÇÃO: $3^{\mathrm{a}}$

LOCAL DE PUBLICAÇÃO: Rio de Janeiro/1960

EDITORA: José Olympio

DATA DA 1ª EDIÇÀO: 1939

PROSA ( $X$ ) POESIA ( )

PERSONAGEM: JUDIA（） ESTRANGEIRA（）

REFERÊNCIAS: A PERSONAGENS OU PESSOAS JUDIAS ( ) A PERSONAGENS OU PESSOAS ESTRANGEIRAS ( )

REFERÊNCIAS: A CULTURA JUDAICA ( $X$ )

A CULTURA ESTRANGEIRA $(X)$

REFERÊNCIAS: INTERTEXTUAIS（） TEXTUAIS（）

SE SIM, QUAIS?

CARACTERÍSTICAS DA PERSONAGEM JUDIA:

- NOME:

- CARACTERÍSTICAS FíSICAS:

A REFERÊNCIA APARECE:

- CAPÍTULO(s) Sepulturas Velhas e em Calvinismo e Judaísmo

- PÁGINA(s) 106 e de 111 à 113

OBSERVAÇÕES ESPECÍFICAS: O autor comenta sobre a presença judaica na cidade de Olinda durante o período conhecido como da Invasão Holandesa. 


$\begin{array}{llll}\text { FICHA No } & 005 & \text { data } & 30 / 09 / 2002\end{array}$

AUTOR: JOSÉ BENTO MONTEIRO LOBATO

TÍTULO DA OBRA: HISTÓRIAS DO MUNDO PARA ÀS CRIANÇAS

EDIÇÃO:

LOCAL DE PUBLICAÇÃO:

EDITORA: BRASILIENSE

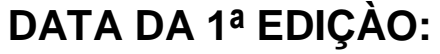

PROSA ( $X$ ) POESIA ( )

PERSONAGEM: JUDIA（） ESTRANGEIRA（）

REFERÊNCIAS: A PERSONAGENS OU PESSOAS JUDIAS ( )

A PERSONAGENS OU PESSOAS ESTRANGEIRAS ( )

REFERÊNCIAS: A CULTURA JUDAICA ( $X$ )

A CULTURA ESTRANGEIRA ( $X$ )

REFERÊNCIAS: INTERTEXTUAIS（） TEXTUAIS（）

SE SIM, QUAIS?

CARACTERÍSTICAS DA PERSONAGEM JUDIA:

- NOME:

- CARACTERÍSTICAS FÍSICAS:

A REFERÊNCIA APARECE:

- CAPÍTULO(s) IX, X, XII e XIII

- PÁGINA(s)

OBSERVAÇÕES ESPECíFICAS: Fala do mito do Judeu Errante e no capítulo que conta a história da II Guerra Mundial não faz qualquer referência ou menção ao Holocausto. 
AUTOR: GILBERTO FREYRE

TíTULO DA OBRA: GUIA PRÁTICO, HISTÓRICO E SENTIMENTAL DA CIDADE DE RECIFE

EDIÇÃO: $4^{\mathrm{a}}$

LOCAL DE PUBLICAÇÃO: Rio de Janeiro

EDITORA: José Olympio/1968

DATA DA $1^{\text {a }}$ EDIÇÀO: 1934

PROSA ( $X$ ) POESIA（ )

PERSONAGEM: JUDIA（） ESTRANGEIRA（）

REFERÊNCIAS: A PERSONAGENS OU PESSOAS JUDIAS ( $X$ )

A PERSONAGENS OU PESSOAS ESTRANGEIRAS $(X)$

REFERÊNCIAS: A CULTURA JUDAICA ( $X$ )

A CULTURA ESTRANGEIRA ( $X$ )

REFERÊNCIAS: INTERTEXTUAIS（） TEXTUAIS（）

SE SIM, QUAIS?

\section{CARACTERÍSTICAS DA PERSONAGEM JUDIA:}

- NOME:

- CARACTERÍSTICAS FÍSICAS:

\section{A REFERÊNCIA APARECE:}

- CAPÍTULO(s) Israelitas no Recife

- PÁGINA(s) 140 e 141

OBSERVAÇÕES ESPECíFICAS: Comenta sobre o período da Invasão Holandesa e a presença judaica, comenta sobre personalidades como Aboab da Fonseca, Rafael Aguilar, Jacob de Andrade Velosino, entre outras personalidades da comunidade judaica no século XVII. Comenta também da fundação de Nova lorque.

Também comenta o período atual (1934, ano da publicação da obra), sobre a cidade de Recife, e o considerável número de judeus, lá residentes, além de distinguir os judeus do século XVII como sefaraditas e os do período atual como Asquenazitas:

Hoje o Recife tem duas sinagogas e um número considerável de judeus: mas não sefardins. judeus arruivados, vindos da Rússia e da Polônia na maior parte.

Os Israelitas - vindos da Europa Central, principalmente, e não mais sefardins, como outrora - recomeçam a ser numerosos no Recife: cidade da qual foram no século XVII parte considerável da população e de onde, há três séculos, seguiram para a então Nova Amsterdã, hoje Nova lorque, os vinte e quatro judeus que com suas famílias fundaram ali uma comunidade de sefardins de origem ibérica que se tornou ilustre. 
AUTOR: GILBERTO FREYRE

TíTULO DA OBRA: CASA-GRANDE \& SENZALA

EDIÇÃO: $12^{\mathrm{a}}$

LOCAL DE PUBLICAÇÃO: Rio de Janeiro

EDITORA: Ed. Universidade de Brasília/1933

DATA DA $1^{\text {a }}$ EDIÇÀO: 1933

PROSA ( $X$ ) POESIA ( )

PERSONAGEM: JUDIA（） ESTRANGEIRA（）

REFERÊNCIAS: A PERSONAGENS OU PESSOAS JUDIAS $(X)$

A PERSONAGENS OU PESSOAS ESTRANGEIRAS $(X)$

REFERÊNCIAS: A CULTURA JUDAICA ( $X$ )

A CULTURA ESTRANGEIRA $(X)$

REFERÊNCIAS: INTERTEXTUAIS ( $X$ ) TEXTUAIS ( )

SE SIM, QUAIS?

Várias

\section{CARACTERÍSTICAS DA PERSONAGEM JUDIA:}

- NOME:

- CARACTERÍSTICAS FÍSICAS:

\section{A REFERÊNCIA APARECE:}

- CAPÍTULO(s)

- PÁGINA(s) 5, 21, 22, 73, 258, 259, 262, 269, 279, 280, 281, 282, 283, 317 e 337 OBSERVAÇÕES ESPECÍFICAS:

Obra de maior destaque na carreira do autor, responsável pela maior parte de seu sucesso, foi traduzida para o inglês, francês e espanhol, além de edições publicadas em Portugal.

Aqui no Brasil chegou a ser editada uma versão resumida em quadrinhos (BD), para o público infanto-juvenil.

Destaque para forma como trata os judeus na obra, pois coloca-os de maneira um tanto preconceituosa, diferente do linguajar utilizado no Manifesto Regionalista e nos Guias Práticos de Cidades. 


FICHA N $^{\circ} 008 \quad$ data $02 / 12 / 2002$

AUTOR: GILBERTO FREYRE

TÍTULO DA OBRA: SOBRADOS E MUCAMBOS

EDIÇÃO: $4^{\mathrm{a}}$

LOCAL DE PUBLICAÇÃO: São Paulo

EDITORA: Companhia Nacional/1968

DATA DA $1^{\text {a }}$ EDIÇÀO: 1933

PROSA ( $X$ ) POESIA ( )

PERSONAGEM: JUDIA（） ESTRANGEIRA（）

REFERÊNCIAS: A PERSONAGENS OU PESSOAS JUDIAS ( )

A PERSONAGENS OU PESSOAS ESTRANGEIRAS（）

REFERÊNCIAS: A CULTURA JUDAICA ( $X$ )

A CULTURA ESTRANGEIRA $(X)$

REFERÊNCIAS: INTERTEXTUAIS（） TEXTUAIS（）

SE SIM, QUAIS?

CARACTERÍSTICAS DA PERSONAGEM JUDIA:

- NOME:

- CARACTERÍSTICAS FÍSICAS:

A REFERÊNCIA APARECE:

- CAPÍTULO(s) I, II e V

- PÁGINA(s) 5, 7, 10, 11, 12, 13, 14, 19, 33, 34, 35, 40, 45, 156, 157, 159, 167 e 186

\section{OBSERVAÇÕES ESPECÍFICAS:}

O judeu é retratado de forma diferenciada nos dois primeiros capítulos, havendo um certo alinhamento com o pensamento eugenista da época, o que não ocorre no capítulo V.

Uma das informações mais importantes existentes no livro é o comentário que faz sobre a institucionalização da prostituição no país e a chegada das "polacas" na corte(pág. 59), no século XIX. 
AUTOR: JOÃO DO RIO (PAULO BARRETO)

TÍTULO DA OBRA: RELIGIÕES NO RIO

EDIÇÃO: $1^{\mathrm{a}}$

LOCAL DE PUBLICAÇÃO: Paris/Rio de Janeiro

EDITORA: H. Garnier, Livreiro - Editor

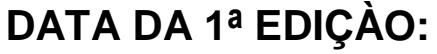

PROSA ( $X$ ) POESIA ( )

PERSONAGEM: JUDIA（） ESTRANGEIRA ( $X$ )

REFERÊNCIAS: A PERSONAGENS OU PESSOAS JUDIAS $(X)$

A PERSONAGENS OU PESSOAS ESTRANGEIRAS $(X)$

REFERÊNCIAS: A CULTURA JUDAICA ( $X$ )

A CULTURA ESTRANGEIRA $(X)$

REFERÊNCIAS: INTERTEXTUAIS（） TEXTUAIS（）

SE SIM, QUAIS?

\section{CARACTERÍSTICAS DA PERSONAGEM JUDIA:}

- NOME:

- CARACTERÍSTICAS FÍSICAS:

\section{A REFERÊNCIA APARECE:}

- CAPÍTULO(s) As Sinagogas

- PÁGINA(s) 06, 07, 66, 163, 237, 238, 239, 240, 241, 242, 243, 244 e 245 OBSERVAÇÕES ESPECÍFICAS:

Crônicas publicadas em jornais e reunidas posteriormente em livro, publicado no início do séc. $X X$, sem haver a indicação precisa do ano de publicação. O livro é composto de crônicas sobre as mais variadas religiões, com comentários ácidos sobre o mercantilismo existente na maioria delas. Fala das religiões afros, mulçumana, evangélicas, cristã, judaica, maronita e outras.

Merece destaque o fato do autor conhecer bem personalidades como os Rothschild, costumes judaicos como os dias sagrados Ano Novo, Dia do Perdão, Pessach), além, é claro, dos prostíbulos onde trabalhavam as polacas. 


\section{FICHA N $^{\circ} 010 \quad$ data $05 / 05 / 2003$}

AUTOR: AMADEU AMARAL

TÍTULO DA OBRA: POESIAS COMPLETAS

EDIÇÃO: $1^{\mathrm{a}}$

LOCAL DE PUBLICAÇÃO: São Paulo

EDITORA: HUCITEC/1977

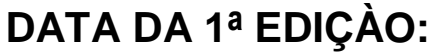

PROSA（ ) POESIA (X)

PERSONAGEM: JUDIA（） ESTRANGEIRA（）

REFERÊNCIAS: A PERSONAGENS OU PESSOAS JUDIAS ( $X$ )

A PERSONAGENS OU PESSOAS ESTRANGEIRAS（）

REFERÊNCIAS: A CULTURA JUDAICA ( $X$ )

A CULTURA ESTRANGEIRA（）

REFERÊNCIAS: INTERTEXTUAIS（） TEXTUAIS（）

SE SIM, QUAIS?

\section{CARACTERÍSTICAS DA PERSONAGEM JUDIA:}

- NOME:

- CARACTERÍSTICAS FÍSICAS:

\section{A REFERÊNCIA APARECE:}

- CAPÍTULO(s) do livro Espumas - Poesia: Jesus entre as crianças

- PÁGINA(s) 172, 173 e 174 OBSERVAÇÕES ESPECÍFICAS:

Esta obra reuni os livros do autor, que foram escritos nas primeiras décadas do séculos XX. 


\section{FICHA N ${ }^{\circ} 011$ data $05 / 05 / 2003$}

AUTOR: AMADEU AMARAL

TÍTULO DA OBRA: LÂMPADA ANTIGA

EDIÇÃO: $1^{\mathrm{a}}$

LOCAL DE PUBLICAÇÃO: SÃO PAULO

EDITORA: Imprensa Methodista

DATA DA 1ª EDIÇÀO: 1922 aproximadamente

PROSA ( ) POESIA (X)

PERSONAGEM: JUDIA（） ESTRANGEIRA（）

REFERÊNCIAS: A PERSONAGENS OU PESSOAS JUDIAS $(X)$

A PERSONAGENS OU PESSOAS ESTRANGEIRAS ( )

REFERÊNCIAS: A CULTURA JUDAICA ( $X$ )

A CULTURA ESTRANGEIRA（）

REFERÊNCIAS: INTERTEXTUAIS（） TEXTUAIS（）

SE SIM, QUAIS?

CARACTERÍSTICAS DA PERSONAGEM JUDIA:

- NOME:

- CARACTERÍSTICAS FÍSICAS:

\section{A REFERÊNCIA APARECE:}

- CAPÍTULO(s) Inimigos Inseparáveis, Sobre uns versos de Castro Alves, O trabalho Libertador

- PÁGINA(s) 25, 26, 53 e 97

OBSERVAÇÕES ESPECÍFICAS:

Fala de Spinosa, Caim e Abel e Ahasverus(qualificado como o hebreu lendário, em poema datado de 1921). 


\section{FICHA N $^{\circ} \quad 012 \quad$ data $06 / 05 / 2003$}

AUTOR: AMADEU AMARAL

TÍTULO DA OBRA: NÉVOA

EDIÇÃO: $1^{\mathrm{a}}$

LOCAL DE PUBLICAÇÃO: São Paulo

EDITORA: Livraria Magalhães

DATA DA 1ª EDIÇÀO: 1910

PROSA（ ) POESIA ( X )

PERSONAGEM: JUDIA（） ESTRANGEIRA（）

REFERÊNCIAS: A PERSONAGENS OU PESSOAS JUDIAS ( $X$ )

A PERSONAGENS OU PESSOAS ESTRANGEIRAS ( )

REFERÊNCIAS: A CULTURA JUDAICA ( $X$ )

A CULTURA ESTRANGEIRA（）

REFERÊNCIAS: INTERTEXTUAIS ( X ) TEXTUAIS ( )

SE SIM, QUAIS?

Ao Cântico dos Cânticos e uma outra citação bíblica do livro dos Reis I:10

\section{CARACTERÍSTICAS DA PERSONAGEM JUDIA:}

- NOME:

- CARACTERÍSTICAS FÍSICAS:

\section{A REFERÊNCIA APARECE:}

- CAPÍtULO(s) Salomão e a Rainha de Sabá I e II, Boaz e Ruth

- PÁGINA(s) 117, 119, 121 e 122

\section{OBSERVAÇÕES ESPECÍFICAS:}

Na parte denominada Evocações estão os dois poemas dedicados as personagens bíblicas(Rei Salomão, Rainha de Sabá, Ruth e Boaz). 
DEPARTAMENTO DE LETRAS ORIENTAIS

FICHA N ${ }^{\circ} \quad 013 \quad$ data $22 / 05 / 2003$

AUTOR: SERAFIM VIEIRA DE ALMEIDA(organizador)

TÍTULO DA OBRA: ANTHOLOGIA DE POETAS SERGIPANOS

EDIÇÃO: $1^{\mathrm{a}}$

LOCAL DE PUBLICAÇÃO: São Paulo

EDITORA: Typographia Cupolo

DATA DA 1ª EDIÇÀO: 1939

PROSA ( ) POESIA (X)

PERSONAGEM: JUDIA ( $X$ ) ESTRANGEIRA（ )

REFERÊNCIAS: A PERSONAGENS OU PESSOAS JUDIAS $(X)$

A PERSONAGENS OU PESSOAS ESTRANGEIRAS $(X)$

REFERÊNCIAS: A CULTURA JUDAICA ( $X$ )

A CULTURA ESTRANGEIRA $(X)$

REFERÊNCIAS: INTERTEXTUAIS（） TEXTUAIS ( $X)$

SE SIM, QUAIS?

Ao Cântico dos Cânticos (pág. 159)

CARACTERÍSTICAS DA PERSONAGEM JUDIA:

- NOME:

- CARACTERÍSTICAS FÍSICAS:

\section{A REFERÊNCIA APARECE:}

- CAPÍTULO(s) Lei do Éden, O festim de Balthazar

- PÁGINA(s) 47, 48, 49, 50, 51, 52, 53, 54 e 112

\section{OBSERVAÇÕES ESPECÍFICAS:}

O livro é composto de 164 poemas escrito por 54 autores diferentes. No Poema Lei do Éden, de Felinto do Nascimento, fala de Adão e Caim. No Poema O Festim de Balthazar, de Elzeario Pinto, fala de Arão, Abrahão, Ephrain, Isaac, David, Salomão, Daniel, do Monte Sinai, de Sodoma, da Torre de Babel e outras citações bíblicas.

A relação de autores é muito extensa, assim citei apenas o nome do organizador e o nome dos poetas que fizeram alguma citação bíblica ou que remeta à cultura judaica. 


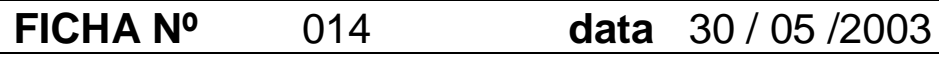

AUTOR: TOBIAS BARRETO

TÍTULO DA OBRA: DIAS E NOITES

EDIÇÃO: $1^{\mathrm{a}}$

LOCAL DE PUBLICAÇÃO: Rio de Janeiro e São Paulo

EDITORA: Laemmert \& Cia. Livreiros e Editores

DATA DA $1^{\text {a }}$ EDIÇÀO: 1903

PROSA（） POESIA ( $X)$

PERSONAGEM: JUDIA（） ESTRANGEIRA（）

REFERÊNCIAS: A PERSONAGENS OU PESSOAS JUDIAS $(X)$

A PERSONAGENS OU PESSOAS ESTRANGEIRAS $(X)$

REFERÊNCIAS: A CULTURA JUDAICA ( $X$ )

A CULTURA ESTRANGEIRA $(X)$

REFERÊNCIAS: INTERTEXTUAIS（） TEXTUAIS（）

SE SIM, QUAIS?

CARACTERÍSTICAS DA PERSONAGEM JUDIA:

- NOME:

- CARACTERÍSTICAS FÍSICAS:

A REFERÊNCIA APARECE:

- CAPÍTULO(s) XXIX - A Polônia; Geraes e Naturalistas

- PÁGINA(s) 89 e 90

OBSERVAÇÕES ESPECÍFICAS:

Obra póstuma publicada por Sylvio Romero em 1903.

Inicialmente dentro do período a ser estudado, a obra ficou excluída da pesquisa com a redução do período(1920-1940), porém em virtude de já ter sido fichada a obra foi mantida na relação de livros pesquisados. 


\section{FICHA N $^{\circ} \quad 015 \quad$ data $01 / 06 / 2003$}

AUTOR: PEDRO CALMON

TÍTULO DA OBRA: JOSÉ DE ANCHIETA - O SANTO DO BRASIL

EDIÇÃO: $1^{\mathrm{a}}$

LOCAL DE PUBLICAÇÃO: São Paulo

EDITORA: Melhoramentos

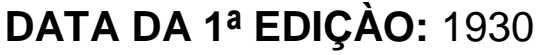

PROSA ( $X$ ) POESIA ( )

PERSONAGEM: JUDIA（） ESTRANGEIRA（）

REFERÊNCIAS: A PERSONAGENS OU PESSOAS JUDIAS ( )

A PERSONAGENS OU PESSOAS ESTRANGEIRAS（）

REFERÊNCIAS: A CULTURA JUDAICA ( $X$ )

A CULTURA ESTRANGEIRA ( $X$ )

REFERÊNCIAS: INTERTEXTUAIS（） TEXTUAIS（）

SE SIM, QUAIS?

CARACTERÍSTICAS DA PERSONAGEM JUDIA:

- NOME:

- CARACTERÍSTICAS FÍSICAS:

\section{A REFERÊNCIA APARECE:}

- CAPÍTULO(s)

- PÁGINA(s) 16, 71, 79, 85 e 99

\section{OBSERVAÇÕES ESPECÍFICAS:}

No texto são inseridas palavras que remetem à cultura judaica ou a episódios históricos que estão relacionados com os judeus, como: pág. 71 fala da inquisição, na pág. 79 aparece a palavra synagoga, na pág. 85 aparece a palavra circuncisão e na pág. 99 está inserida a palavra Israel. 
AUTOR: JORGE DE LIMA

TÍTULO DA OBRA: ANCHIETA

EDIÇÃO: $1^{\mathrm{a}}$

LOCAL DE PUBLICAÇÃO: Rio de Janeiro

EDITORA: Civilização Brasileira

DATA DA 1 ${ }^{a}$ EDIÇÀO: 1934

PROSA (X ) POESIA ( )

PERSONAGEM: JUDIA（） ESTRANGEIRA（）

REFERÊNCIAS: A PERSONAGENS OU PESSOAS JUDIAS ( ) A PERSONAGENS OU PESSOAS ESTRANGEIRAS ( )

REFERÊNCIAS: A CULTURA JUDAICA ( $X$ )

A CULTURA ESTRANGEIRA（）

REFERÊNCIAS: INTERTEXTUAIS（） TEXTUAIS（）

SE SIM, QUAIS?

CARACTERÍSTICAS DA PERSONAGEM JUDIA:

- NOME:

- CARACTERÍSTICAS FÍSICAS:

A REFERÊNCIA APARECE:

- CAPÍTULO(s)

- PÁGINA(s) 32, 62, 64 e 69

OBSERVAÇÕES ESPECÍFICAS:

Pág. 32 - fala da Caim;

Pág. 62 - citação: "João Ramalho era tão agudo que parecia judeu. Certo Investigador, estudando-lhe a assinatura enxergou mesmo nas garatujas deste homem extraordinário o kaf cabalístico."

Pág 64 - citação: "Um dos moradores desta terra era um Joannes de Bolés, homem douto nas letras latinas, gregas, hebraicas,

Pág. 69 - citação: "O pernóstico enfeitara isso tudo com citações em grego e hebraico........." 


$\begin{array}{llll}\text { FICHA N }^{\circ} & 017 & \text { data } & 07 / 06 / 2003\end{array}$

AUTOR: ALPHONSUS DE GUIMARÃES (Afonso Henriques da Costa Guimarães)

TíTULO DA OBRA: CARTA DE AMOR, SALMOS DE PRECE: estudo crítico de Henriqueta Lisboa

EDIÇÃO: $1^{\mathrm{a}}$

LOCAL DE PUBLICAÇÃO: Rio de Janeiro

EDITORA: Cia. José Aguilar Editora

DATA DA $1^{\text {a }}$ EDIÇÀO: 1972

PROSA（） POESIA (X)

PERSONAGEM: JUDIA（） ESTRANGEIRA（）

REFERÊNCIAS: A PERSONAGENS OU PESSOAS JUDIAS ( $X$ )

A PERSONAGENS OU PESSOAS ESTRANGEIRAS（）

REFERÊNCIAS: A CULTURA JUDAICA ( $X$ )

A CULTURA ESTRANGEIRA（）

REFERÊNCIAS: INTERTEXTUAIS（） TEXTUAIS（）

SE SIM, QUAIS?

CARACTERÍSTICAS DA PERSONAGEM JUDIA:

- NOME:

- CARACTERÍSTICAS FÍSICAS:

\section{A REFERÊNCIA APARECE:}

- CAPÍTULO(s)

- PÁGINA(s) 92, 145 e 184

OBSERVAÇÕES ESPECÍFICAS:

A obra recupera a obra do autor que foi publicada no início do século $X X$, como: Dona Mística de 1900, Pastoral aos Crentes de Amor e da Morte de 1923 e Pulvis de 1938(publicado após a sua morte).

Nas poesias aparecem palavras como: sabá, Jerusalém, filhos de Israel, festa a Abraão, e aos descendentes dessa sacrossanta estirpe..... 
AUTOR: ADHERBAL DE CARVALHO

TÍTULO DA OBRA: ESBOÇOS LITERÁRIOS

EDIÇÃO: $1^{\mathrm{a}}$

LOCAL DE PUBLICAÇÃO: Rio de Janeiro

EDITORA: H. Garnier

DATA DA $1^{\text {a }}$ EDIÇÀO: 1902

PROSA ( $X$ ) POESIA ( )

PERSONAGEM: JUDIA $(X)$ ESTRANGEIRA $(X)$

REFERÊNCIAS: A PERSONAGENS OU PESSOAS JUDIAS ( $X$ )

A PERSONAGENS OU PESSOAS ESTRANGEIRAS $(X)$

REFERÊNCIAS: A CULTURA JUDAICA ( $X$ )

A CULTURA ESTRANGEIRA $(X)$

REFERÊNCIAS: INTERTEXTUAIS（） TEXTUAIS ( $X$ )

SE SIM, QUAIS?

Trechos de livros de Aluísio de Azevedo, como: O Mulato e O Cortiço

CARACTERÍSTICAS DA PERSONAGEM JUDIA:

- NOME:

- CARACTERÍSTICAS FÍSICAS:

\section{A REFERÊNCIA APARECE:}

- CAPÍTULO(s) O Naturalismo no Brasil

- PÁGINA(s) 60

\section{OBSERVAÇÕES ESPECÍFICAS:}

Aparece o nome de várias personalidades estrangeiras, entre elas o do higienista Michel Levy.

Esta obra estava inserida no período inicial(1900 à 1945), porém após a redução do período a ser pesquisado, acabou por ser excluída da pesquisa. Como já havia sido feito o fichamento do livro foi mantida no rol de obras estudadas. 
AUTOR: CARLOS DE VASCONCELOS

TÍTULO DA OBRA: CAZADOS NA AMÉRICA

EDIÇÃO: $1^{\mathrm{a}}$

LOCAL DE PUBLICAÇÃO: Nova Yorque

EDITORA: nada consta, o livro apresenta aspecto de impressão particular

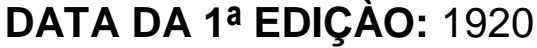

PROSA ( $X$ ) POESIA ( )

PERSONAGEM: JUDIA（） ESTRANGEIRA ( $X$ )

REFERÊNCIAS: A PERSONAGENS OU PESSOAS JUDIAS ( $X$ )

A PERSONAGENS OU PESSOAS ESTRANGEIRAS $(X)$

REFERÊNCIAS: A CULTURA JUDAICA ( $X$ )

A CULTURA ESTRANGEIRA $(X)$

REFERÊNCIAS: INTERTEXTUAIS（） TEXTUAIS（）

SE SIM, QUAIS?

\section{CARACTERÍSTICAS DA PERSONAGEM JUDIA:}

- NOME:

- CARACTERÍSTICAS FÍSICAS:

\section{A REFERÊNCIA APARECE:}

- CAPÍTULO(s) Jim, Evelyn, Gus Mildred

- PÁGINA(s) 25, 93, 151 e 160

\section{OBSERVAÇÕES ESPECÍFICAS:}

Na pág. 93 o autor utiliza o termo "ladino", de forma pejorativa, para dizer que a personagem havia compreendido de forma maliciosa.

Na pág. 151 utiliza o termo Judeu Errante, conforme segue a citação: "É um torresmo seu Joe! - Dizia ao outro, judeu errante que grilhava o português por haver estado na llha da madeira... ......

Na pág. 160 menciona a palavra "caftens". 


\section{FICHA N $^{\circ} \quad 020 \quad$ data $15 / 06 / 2003$}

AUTOR: GUILERME DE ALMEIDA

TíTULO DA OBRA: ACASO: versos de todo tempo

EDIÇÃO: $1^{\mathrm{a}}$

LOCAL DE PUBLICAÇÃO: São Paulo

\section{EDITORA:}

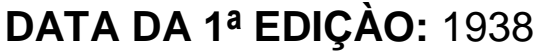

PROSA ( ) POESIA (X)

PERSONAGEM: JUDIA（） ESTRANGEIRA（）

REFERÊNCIAS: A PERSONAGENS OU PESSOAS JUDIAS ( )

A PERSONAGENS OU PESSOAS ESTRANGEIRAS ( $X$ )

REFERÊNCIAS: A CULTURA JUDAICA ( $X$ )

A CULTURA ESTRANGEIRA ( $X$ )

REFERÊNCIAS: INTERTEXTUAIS（） TEXTUAIS（）

SE SIM, QUAIS?

\section{CARACTERÍSTICAS DA PERSONAGEM JUDIA:}

- NOME:

- CARACTERÍSTICAS FÍSICAS:

\section{A REFERÊNCIA APARECE:}

- CAPÍTULO(s)

- PÁGINA(s)

OBSERVAÇÕES ESPECÍFICAS:

A parte II do livro é composta de versos traduzidos para o português pelo próprio autor, há versos dos mais variados autores, entre eles Goethe. 


FICHA No 021 data $20 / 06 / 2003$

AUTOR: GILBERTO FREYRE

TÍTULO DA OBRA: UM ENGENHEIRO FRANCÊS NO BRASIL

EDIÇÃO: $2^{\mathrm{a}}$

LOCAL DE PUBLICAÇÃO: Rio de Janeiro

EDITORA: José Olympio

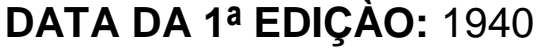

PROSA ( $X$ ) POESIA ( )

PERSONAGEM: JUDIA（） ESTRANGEIRA（）

REFERÊNCIAS: A PERSONAGENS OU PESSOAS JUDIAS ( $X$ )

A PERSONAGENS OU PESSOAS ESTRANGEIRAS $(X)$

REFERÊNCIAS: A CULTURA JUDAICA ( $X$ )

A CULTURA ESTRANGEIRA $(X)$

REFERÊNCIAS: INTERTEXTUAIS（） TEXTUAIS ( $X)$

SE SIM, QUAIS?

De diversos autores

CARACTERÍSTICAS DA PERSONAGEM JUDIA:

- NOME:

- CARACTERÍSTICAS FÍSICAS:

A REFERÊNCIA APARECE:

- CAPÍTULO(s)

- PÁGINA(s) 40, 41, 42, 43, 190 e 200

OBSERVAÇÕES ESPECÍFICAS:

Fala dos judeus em Recife e do Judaismo quando recorda o passado e quando recorda o Recife da era de Nassau. Porém ha uma forte tendência a se referir ao assunto de forma pejorativa ou colocando citações de outros autores que também menosprezam o judeu. 


\section{FICHA N $^{\circ} 022$ data $30 / 06 / 2003$}

AUTOR: GALEÀO COUTINHO

TÍTULO DA OBRA: PARQUE ANTIGO

EDIÇÃO: $1^{\mathrm{a}}$

LOCAL DE PUBLICAÇÃO: São Paulo

EDITORA: SARAIVA

DATA DA $1^{\text {a }}$ EDIÇÀO: 1920

PROSA（ ) POESIA ( $X)$

PERSONAGEM: JUDIA（） ESTRANGEIRA（）

REFERÊNCIAS: A PERSONAGENS OU PESSOAS JUDIAS ( )

A PERSONAGENS OU PESSOAS ESTRANGEIRAS（）

REFERÊNCIAS: A CULTURA JUDAICA ( $X$ )

A CULTURA ESTRANGEIRA（）

REFERÊNCIAS: INTERTEXTUAIS ( $X$ ) TEXTUAIS ( )

SE SIM, QUAIS?

Com versos biblícos

CARACTERÍSTICAS DA PERSONAGEM JUDIA:

- NOME:

- CARACTERÍSTICAS FÍSICAS:

A REFERÊNCIA APARECE:

- CAPÍTULO(s) Sacrifício de Ruth

- PÁGINA(s) 10 e 11

OBSERVAÇÕES ESPECÍFICAS:

Há referências há personagens bíblicos como Ruth, Boaz e Naomi. 


$\begin{array}{lll}\text { FICHA No }^{\circ} & 023 & \text { data } 30 / 08 / 2003\end{array}$

AUTOR: GILBERTO FREYRE

TÍTULO DA OBRA: NORDESTE

EDIÇÃO: $1^{\mathrm{a}}$

LOCAL DE PUBLICAÇÃO: Rio de Janeiro

EDITORA: José Olympio

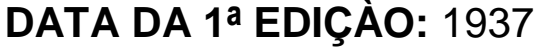

PROSA ( $X$ ) POESIA ( )

PERSONAGEM: JUDIA（） ESTRANGEIRA（）

REFERÊNCIAS: A PERSONAGENS OU PESSOAS JUDIAS ( $X$ )

A PERSONAGENS OU PESSOAS ESTRANGEIRAS $(X)$

REFERÊNCIAS: A CULTURA JUDAICA ( $X$ )

A CULTURA ESTRANGEIRA $(X)$

REFERÊNCIAS: INTERTEXTUAIS ( $X$ ) TEXTUAIS ( )

SE SIM, QUAIS?

A obra Dom Quixote de Miguel de Cervantes, na pág. 45

\section{CARACTERÍSTICAS DA PERSONAGEM JUDIA:}

- NOME:

- CARACTERÍSTICAS FÍSICAS:

\section{A REFERÊNCIA APARECE:}

- CAPÍtULO(s) V - A Canna e o Homem

- PÁGINA(s) 26, 108, 132, 150, 160, 161, 196, 199 e 207

OBSERVAÇÕES ESPECÍFICAS:

Comenta sobre algumas personalidades da comunidade judaica como Duarte Coelho, no período colonial, além de Melville J. Herskovits e Samuel Hardman no período contenporâneo. 


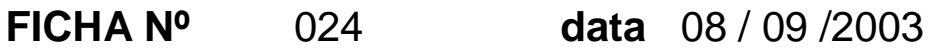

AUTOR: JOSÉ LANNES

TÍTULO DA OBRA: VANA

EDIÇÃO: $1^{\mathrm{a}}$

LOCAL DE PUBLICAÇÃO: São Paulo

EDITORA:

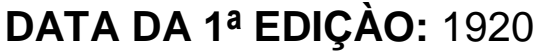

PROSA（） POESIA ( $X)$

PERSONAGEM: JUDIA（） ESTRANGEIRA（）

REFERÊNCIAS: A PERSONAGENS OU PESSOAS JUDIAS ( )

A PERSONAGENS OU PESSOAS ESTRANGEIRAS（）

REFERÊNCIAS: A CULTURA JUDAICA（ )

A CULTURA ESTRANGEIRA（）

REFERÊNCIAS: INTERTEXTUAIS（） TEXTUAIS（）

SE SIM, QUAIS?

CARACTERÍSTICAS DA PERSONAGEM JUDIA:

- NOME:

- CARACTERÍSTICAS FÍSICAS:

A REFERÊNCIA APARECE:

- CAPÍTULO(s)

- PÁGINA(s)

OBSERVAÇÕES ESPECÍFICAS:

Não há elementos a serem estudados 
AUTOR: CANTO E MELO

TÍTULO DA OBRA: RELÍQUIAS DA MEMÓRIA

EDIÇÃO: $1^{\mathrm{a}}$

LOCAL DE PUBLICAÇÃO: São Paulo

EDITORA: O Pensamento

DATA DA $1^{\text {a }}$ EDIÇÀO: 1920

PROSA ( $X$ ) POESIA ( )

PERSONAGEM: JUDIA（） ESTRANGEIRA（）

REFERÊNCIAS: A PERSONAGENS OU PESSOAS JUDIAS ( )

A PERSONAGENS OU PESSOAS ESTRANGEIRAS $(X)$

REFERÊNCIAS: A CULTURA JUDAICA（）

A CULTURA ESTRANGEIRA ( $X$ )

REFERÊNCIAS: INTERTEXTUAIS（） TEXTUAIS（）

SE SIM, QUAIS?

CARACTERÍSTICAS DA PERSONAGEM JUDIA:

- NOME:

- CARACTERÍSTICAS FÍSICAS:

A REFERÊNCIA APARECE:

- CAPÍTULO(s)

- PÁGINA(s)

OBSERVAÇÕES ESPECÍFICAS:

Aborda muito da cultura espanhola e um pouco da cigana, os personagens falam ou escrevem em espanhol, possuem nomes ou mesmo são descendentes de espanhóis 
AUTOR: JULIA LOPES DE ALMEIDA

TÍTULO DA OBRA: JORNADAS DO MEU PAÍS

EDIÇÃO: $1^{\mathrm{a}}$

LOCAL DE PUBLICAÇÃO: Rio de Janeiro

EDITORA: Livraria Francisco Alves

DATA DA $1^{\text {a }}$ EDIÇÀO: 1920

PROSA ( $X$ ) POESIA ( )

PERSONAGEM: JUDIA（） ESTRANGEIRA（）

REFERÊNCIAS: A PERSONAGENS OU PESSOAS JUDIAS ( $X$ )

A PERSONAGENS OU PESSOAS ESTRANGEIRAS $(X)$

REFERÊNCIAS: A CULTURA JUDAICA ( )

A CULTURA ESTRANGEIRA ( $X$ )

REFERÊNCIAS: INTERTEXTUAIS（） TEXTUAIS（）

SE SIM, QUAIS?

CARACTERÍSTICAS DA PERSONAGEM JUDIA:

- NOME:

- CARACTERÍSTICAS FÍSICAS:

\section{A REFERÊNCIA APARECE:}

- CAPÍTULO(s)

- PÁGINA(s)

OBSERVAÇÕES ESPECÍFICAS:

Como era comum na época, a obra comenta sobre diversas personalidades estrangeiras como Augusto Comte, E. Zola, Oscar Wilde e faz referências às culturas francesa, inglesa, americana e argentina. Também comenta sobre o personagem bíblico Abrahão.

O livro também aborda a colonização alemão e polonesa no sul do país. 


\section{FICHA N $^{\circ} \quad 027 \quad$ data $16 / 10 / 2003$}

AUTOR: SOUZA BANDEIRA (J.C.)

TÍTULO DA OBRA: EVOCAÇÕES E OUTROS ESCRITORES

EDIÇÃO: $1^{\mathrm{a}}$

LOCAL DE PUBLICAÇÃO: Rio de Janeiro

EDITORA: Livraria Castilho

DATA DA $1^{\text {a }}$ EDIÇÀO: 1920

PROSA ( $X$ ) POESIA（ )

PERSONAGEM: JUDIA（） ESTRANGEIRA（）

REFERÊNCIAS: A PERSONAGENS OU PESSOAS JUDIAS $(X)$

A PERSONAGENS OU PESSOAS ESTRANGEIRAS $(X)$

REFERÊNCIAS: A CULTURA JUDAICA（）

A CULTURA ESTRANGEIRA ( $X$ )

REFERÊNCIAS: INTERTEXTUAIS（） TEXTUAIS（）

SE SIM, QUAIS?

CARACTERÍSTICAS DA PERSONAGEM JUDIA:

- NOME:

- CARACTERÍSTICAS FÍSICAS:

\section{A REFERÊNCIA APARECE:}

- CAPÍTULO(s)

- PÁGINA(s) 65

\section{OBSERVAÇÕES ESPECÍFICAS:}

Comenta sobre Recife/PE e na página 65 fala sobre Duarte Coelho, porém não o identifica como judeu ou cristão novo. Também aborda o período holandês em Pernambuco sem fazer qualquer menção a judeus que viveram lá naquele mesmo período. 


FICHA No 028 data $27 / 10 / 2003$

AUTOR: COELHO NETO, AFRÂNIO PEIXOTO MEDEIROS DE ALBUQUERQUE E VIRIATO CORRÊA

TÍTULO DA OBRA: O MYSTÉRIO

EDIÇÃO: $3^{\mathrm{a}}$

LOCAL DE PUBLICAÇÃO: São Paulo

EDITORA: CIA. EDITORA NACIONAL/1928

DATA DA $1^{\text {a }}$ EDIÇÀO: 1920

PROSA ( $X$ ) POESIA（ )

PERSONAGEM: JUDIA（） ESTRANGEIRA（）

REFERÊNCIAS: A PERSONAGENS OU PESSOAS JUDIAS ( )

A PERSONAGENS OU PESSOAS ESTRANGEIRAS $(X)$

REFERÊNCIAS: A CULTURA JUDAICA（ )

A CULTURA ESTRANGEIRA ( $X$ )

REFERÊNCIAS: INTERTEXTUAIS（） TEXTUAIS（）

SE SIM, QUAIS?

CARACTERÍSTICAS DA PERSONAGEM JUDIA:

- NOME:

- CARACTERÍSTICAS FÍSICAS:

A REFERÊNCIA APARECE:

- CAPÍTULO(s)

- PÁGINA(s)

OBSERVAÇÕES ESPECÍFICAS:

Não há elementos da cultura judaica a serem estudados. Foi publicado como folhetim de jornal e posteriormente ganhou o formato livro.

Há muitas referências à cultura francesa, inclusive com citações em francês e comentários sobre o escritor Victor Hugo. 


\section{FICHA N $^{\circ} \quad 029 \quad$ data $02 / 11 / 2003$}

AUTOR: AFRÂNIO PEIXOTO

TÍTULO DA OBRA: PARÁBOLAS

EDIÇÃO: $2^{\mathrm{a}}$

LOCAL DE PUBLICAÇÃO: São Paulo

EDITORA: Cia. Editora Nacional/1943

DATA DA 1 ${ }^{\text {a }}$ EDIÇÀO: 1920

PROSA (X) POESIA ( )

PERSONAGEM: JUDIA（） ESTRANGEIRA（）

REFERÊNCIAS: A PERSONAGENS OU PESSOAS JUDIAS ( $X$ )

A PERSONAGENS OU PESSOAS ESTRANGEIRAS $(X)$

REFERÊNCIAS: A CULTURA JUDAICA $(X)$

A CULTURA ESTRANGEIRA ( $X$ )

REFERÊNCIAS: INTERTEXTUAIS（） TEXTUAIS（）

SE SIM, QUAIS?

\section{CARACTERÍSTICAS DA PERSONAGEM JUDIA:}

- NOME:

- CARACTERÍSTICAS FÍSICAS:

\section{A REFERÊNCIA APARECE:}

- CAPÍTULO(s) Crônica Coitado dos Ricos

- PÁGINA(s) 30, 90, 292, 295, 296 e 297 OBSERVAÇÕES ESPECÍFICAS:

Livro de crônicas, onde o autor classifica os judeus como usurários e desonestos.

"A desgraça toda do povo judeu é gostar do dinheiro e guardá-lo, tentando por êle, oprimir os outros." (pág. 295)

Comenta sobre os Rothschild, inquisição, pesquisa de sangue e árvores genealógicas e campos de concentração:

"Antes não ser Rothschild... Ao menos não se tem a perspectiva merecida dos campos de concentração..."(pág. 296) 


FICHA No $030 \quad$ data $14 / 11 / 2003$

AUTOR: COELHO NETO

TÍTULO DA OBRA: CONTOS DA VIDA E DA MORTE

EDIÇÃO: $1^{\text {a }}$

LOCAL DE PUBLICAÇÃO: Porto - Portugal

EDITORA: Livraria Chardron, de Lello e Irmão Ltda.

DATA DA $1^{\text {a }}$ EDIÇÀO: 1927

PROSA (X) POESIA ( )

PERSONAGEM: JUDIA（） ESTRANGEIRA（）

REFERÊNCIAS: A PERSONAGENS OU PESSOAS JUDIAS ( )

A PERSONAGENS OU PESSOAS ESTRANGEIRAS ( $X$ )

REFERÊNCIAS: A CULTURA JUDAICA ( $X$ )

A CULTURA ESTRANGEIRA $(X)$

REFERÊNCIAS: INTERTEXTUAIS（） TEXTUAIS（）

SE SIM, QUAIS?

CARACTERÍSTICAS DA PERSONAGEM JUDIA:

- NOME:

- CARACTERÍSTICAS FÍSICAS:

A REFERÊNCIA APARECE:

- CAPÍTULO(s)

- PÁGINA(s) 153 e 223

OBSERVAÇÕES ESPECÍFICAS:

No meio da obra o autor insere figuras como Ulisses e Penélope, Cyrano de Bergerac e Romeu e Julieta.

Pág. 153 fala em "pão azymo"

Pág. 223 fala em "sabbat" 


\section{FICHA N $^{\circ} 031$ data $02 / 12 / 2003$}

AUTOR: MEDEIROS E ALBUQUERQUE

TÍTULO DA OBRA: MARTA

EDIÇÃO: $1^{\mathrm{a}}$

LOCAL DE PUBLICAÇÃO: Rio de Janeiro

EDITORA: Francisco Alves

DATA DA $1^{\text {a }}$ EDIÇÀO: 1920

PROSA ( $X$ ) POESIA ( )

PERSONAGEM: JUDIA（） ESTRANGEIRA（）

REFERÊNCIAS: A PERSONAGENS OU PESSOAS JUDIAS ( )

A PERSONAGENS OU PESSOAS ESTRANGEIRAS $(X)$

REFERÊNCIAS: A CULTURA JUDAICA ( $X$ )

A CULTURA ESTRANGEIRA ( $X$ )

REFERÊNCIAS: INTERTEXTUAIS（） TEXTUAIS（）

SE SIM, QUAIS?

CARACTERÍSTICAS DA PERSONAGEM JUDIA:

- NOME:

- CARACTERÍSTICAS FÍSICAS:

A REFERÊNCIA APARECE:

- CAPÍTULO(s)

- PÁGINA(s) 7

OBSERVAÇÕES ESPECÍFICAS:

Começa falando de antisemitismo e fala da religião judaica de forma depreciativa.

Na pág. 07 cito: "O ninho de judeus era o hotel White, na Tijuca, Efetivamente havia lá 4 ou 5 famílias judias veraneando." 


\section{$\begin{array}{lll}\text { FICHA N }^{\circ} & 032 & \text { data } 20 / 12 / 2003\end{array}$}

AUTOR: COELHO NETO

TÍTULO DA OBRA: MANO

EDIÇÃO: $4^{\mathrm{a}}$

LOCAL DE PUBLICAÇÃO: Porto

EDITORA: Livraria Lello e Irmão/1936

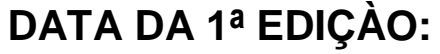

PROSA（ ) POESIA (X)

PERSONAGEM: JUDIA（） ESTRANGEIRA（）

REFERÊNCIAS: A PERSONAGENS OU PESSOAS JUDIAS ( )

A PERSONAGENS OU PESSOAS ESTRANGEIRAS（）

REFERÊNCIAS: A CULTURA JUDAICA（）

A CULTURA ESTRANGEIRA ( $X$ )

REFERÊNCIAS: INTERTEXTUAIS（） TEXTUAIS（）

SE SIM, QUAIS?

CARACTERÍSTICAS DA PERSONAGEM JUDIA:

- NOME:

- CARACTERÍSTICAS FÍSICAS:

A REFERÊNCIA APARECE:

- CAPÍTULO(s)

- PÁGINA(s)

OBSERVAÇÕES ESPECÍFICAS:

Não há elementos a serem estudados 


\section{FICHA N $^{\circ} \quad 033 \quad$ data $25 / 12 / 2003$}

AUTOR: GUILHERME DE ALMEIDA

TíTULO DA OBRA: ERA UMA VEZ: versos de Guilherme de Almeida

EDIÇÃO: $1^{\text {a }}$

LOCAL DE PUBLICAÇÃO: São Paulo

EDITORA:

DATA DA $1^{\text {a }}$ EDIÇÀO: 1922

PROSA ( ) POESIA ( $X)$

PERSONAGEM: JUDIA（） ESTRANGEIRA（）

REFERÊNCIAS: A PERSONAGENS OU PESSOAS JUDIAS ( )

A PERSONAGENS OU PESSOAS ESTRANGEIRAS（）

REFERÊNCIAS: A CULTURA JUDAICA（ )

A CULTURA ESTRANGEIRA ( $X$ )

REFERÊNCIAS: INTERTEXTUAIS（） TEXTUAIS（）

SE SIM, QUAIS?

CARACTERÍSTICAS DA PERSONAGEM JUDIA:

- NOME:

- CARACTERÍSTICAS FÍSICAS:

A REFERÊNCIA APARECE:

- CAPÍTULO(s)

- PÁGINA(s)

OBSERVAÇÕES ESPECÍFICAS:

Não há elementos a serem estudados 


\section{FICHA N $^{\circ} \quad 034 \quad$ data $02 / 01 / 2004$}

AUTOR: PAULO MENOTTI DEL PICCHIA

TÍTULO DA OBRA: AS MÁSCARAS

EDIÇÃO: $5^{\mathrm{a}}$

LOCAL DE PUBLICAÇÃO: São Paulo

EDITORA: Cia. Editora Nacional

DATA DA $1^{\text {a }}$ EDIÇÀO: 1920

PROSA ( $X$ ) POESIA ( )

PERSONAGEM: JUDIA（） ESTRANGEIRA（）

REFERÊNCIAS: A PERSONAGENS OU PESSOAS JUDIAS ( )

A PERSONAGENS OU PESSOAS ESTRANGEIRAS（）

REFERÊNCIAS: A CULTURA JUDAICA ( )

A CULTURA ESTRANGEIRA（）

REFERÊNCIAS: INTERTEXTUAIS（） TEXTUAIS（）

SE SIM, QUAIS?

CARACTERÍSTICAS DA PERSONAGEM JUDIA:

- NOME:

- CARACTERÍSTICAS FÍSICAS:

A REFERÊNCIA APARECE:

- CAPÍTULO(s)

- PÁGINA(s)

OBSERVAÇÕES ESPECÍFICAS:

Não há elementos a serem estudados 


\section{FICHA N $^{\circ} \quad 035 \quad$ data $10 / 01 / 2004$}

AUTOR: HENRIQUE MAXIMILIANO COELHO NETO

TÍTULO DA OBRA: TORMENTA

EDIÇÃO: $3^{\mathrm{a}}$

LOCAL DE PUBLICAÇÃO: Porto

EDITORA: Livraria Chardon, De Lello e irmão Ltda/1924

DATA DA $1^{\text {a }}$ EDIÇÀO:

PROSA (X) POESIA ( )

PERSONAGEM: JUDIA（） ESTRANGEIRA（）

REFERÊNCIAS: A PERSONAGENS OU PESSOAS JUDIAS ( )

A PERSONAGENS OU PESSOAS ESTRANGEIRAS ( $X$ )

REFERÊNCIAS: A CULTURA JUDAICA ( $X$ )

A CULTURA ESTRANGEIRA ( $X$ )

REFERÊNCIAS: INTERTEXTUAIS（） TEXTUAIS（）

SE SIM, QUAIS?

CARACTERÍSTICAS DA PERSONAGEM JUDIA:

- NOME:

- CARACTERÍSTICAS FÍSICAS:

A REFERÊNCIA APARECE:

- CAPÍtUlo(s)

- PÁGINA(s) 197

OBSERVAÇÕES ESPECÍFICAS:

Faz referências a figuras como Sancho Pança da obra de Cervantes e ao músico Wagner.

Na página 197 aparece uma referência ao sabbat associada a Mephistopheles. 


\section{$\begin{array}{llll}\text { FICHA N }^{\circ} & 036 & \text { data } & 15 / 01 / 2004\end{array}$}

AUTOR: COELHO NETO

TÍTULO DA OBRA: SERTÃO

EDIÇÃO:

LOCAL DE PUBLICAÇÃO: Porto

EDITORA: Livraria Lello, Ltda/1933

DATA DA $1^{\text {a }}$ EDIÇÀO: 1921

PROSA ( $X$ ) POESIA ( )

PERSONAGEM: JUDIA（） ESTRANGEIRA（）

REFERÊNCIAS: A PERSONAGENS OU PESSOAS JUDIAS ( )

A PERSONAGENS OU PESSOAS ESTRANGEIRAS（）

REFERÊNCIAS: A CULTURA JUDAICA ( $X$ )

A CULTURA ESTRANGEIRA（）

REFERÊNCIAS: INTERTEXTUAIS（） TEXTUAIS（）

SE SIM, QUAIS?

CARACTERÍSTICAS DA PERSONAGEM JUDIA:

- NOME:

- CARACTERÍSTICAS FÍSICAS:

A REFERÊNCIA APARECE:

- CAPÍTULO(s)

- PÁGINA(s) 47

OBSERVAÇÕES ESPECÍFICAS:

Faz uma referência ao Sabbat: "Os astros puros concorriam, todo o céu cedera o seu contingente fulcite para o sabbat." 


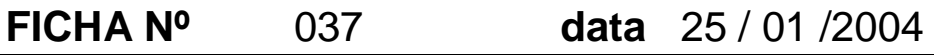

AUTOR: AMADEU AMARAL

TÍTULO DA OBRA: UM SONETO DE BILAC

EDIÇÃO: $1^{\mathrm{a}}$

LOCAL DE PUBLICAÇÃO: Jau/SP

EDITORA: Jahú Club

DATA DA $1^{\text {a }}$ EDIÇÀO: 1920

PROSA ( $X$ ) POESIA ( )

PERSONAGEM: JUDIA（） ESTRANGEIRA（）

REFERÊNCIAS: A PERSONAGENS OU PESSOAS JUDIAS ( )

A PERSONAGENS OU PESSOAS ESTRANGEIRAS ( $X$ )

REFERÊNCIAS: A CULTURA JUDAICA ( $X$ )

A CULTURA ESTRANGEIRA（）

REFERÊNCIAS: INTERTEXTUAIS（）TEXTUAIS（）

SE SIM, QUAIS?

\section{CARACTERÍSTICAS DA PERSONAGEM JUDIA:}

- NOME:

- CARACTERÍSTICAS FÍSICAS:

\section{A REFERÊNCIA APARECE:}

- CAPÍTULO(s)

- PÁGINA(s)

OBSERVAÇÕES ESPECÍFICAS:

A obra é a compilação de uma conferência realizada pelo autor no Jahú Club em 25/08/1920.

No texto aparecem referências a Camões, Victor Hugo e vários outros escritores franceses. Também existem referências a Jacó, Labão e Rachel, personagens bíblicos e que fazem parte da religião judaica. 
AUTOR: JOÃO CARNEIRO DE SOUZA BANDEIRA

TÍTULO DA OBRA: EVOCAÇÕES E OUTROS ESCRITOS

EDIÇÃO: $1^{\mathrm{a}}$

LOCAL DE PUBLICAÇÃO: Rio de Janeiro

EDITORA: Livraria Castilho

DATA DA 1ª EDIÇÀO: 1920

PROSA (X ) POESIA ( )

PERSONAGEM: JUDIA（） ESTRANGEIRA（）

REFERÊNCIAS: A PERSONAGENS OU PESSOAS JUDIAS ( $X$ )

A PERSONAGENS OU PESSOAS ESTRANGEIRAS ( $X$ )

REFERÊNCIAS: A CULTURA JUDAICA（ )

A CULTURA ESTRANGEIRA ( $X$ )

REFERÊNCIAS: INTERTEXTUAIS ( $X$ ) TEXTUAIS ( $X$ )

SE SIM, QUAIS?

Há referências intertextuais com Ulisses e textuais de Shakespeare

\section{CARACTERÍSTICAS DA PERSONAGEM JUDIA:}

- NOME:

- CARACTERÍSTICAS FÍSICAS:

\section{A REFERÊNCIA APARECE:}

- CAPÍTULO(s)

- PÁGINA(s) 65, 162 e 179

OBSERVAÇÕES ESPECÍFICAS:

Faz referências a Giordano Bruno na pág. 162, comenta sobre o caso Dreyfus na pág. 179. Também fala sobre Duarte Coelho(cristão-novo do período colonial).

O livro apresenta várias referências às culturas Inglesa, grega e alemã. O autor comenta sobre Göethe, Shakespeare, Kant, Byron e Schopenhauer. 


$\begin{array}{llll}\text { FICHA N }^{\circ} & 039 & \text { data } & 10 / 02 / 2004\end{array}$

AUTOR: JOÃO DE BARROS

TÍTULO DA OBRA: OLAVO BILAC E EUCLIDES DA CUNHA

EDIÇÃO: $1^{\mathrm{a}}$

LOCAL DE PUBLICAÇÃO: Lisboa

EDITORA: Livraria Aillaud \& Bertrand

DATA DA $1^{\text {a }}$ EDIÇÀO: 1923

PROSA ( $X$ ) POESIA ( $X)$

PERSONAGEM: JUDIA（） ESTRANGEIRA（）

REFERÊNCIAS: A PERSONAGENS OU PESSOAS JUDIAS ( )

A PERSONAGENS OU PESSOAS ESTRANGEIRAS $(X)$

REFERÊNCIAS: A CULTURA JUDAICA ( )

A CULTURA ESTRANGEIRA（）

REFERÊNCIAS: INTERTEXTUAIS（） TEXTUAIS ( $X$ )

SE SIM, QUAIS?

Euclides da Cunha em Os Sertões

CARACTERÍSTICAS DA PERSONAGEM JUDIA:

- NOME:

- CARACTERÍSTICAS FÍSICAS:

A REFERÊNCIA APARECE:

- CAPÍTULO(s)

- PÁGINA(s)

OBSERVAÇÕES ESPECÍFICAS:

Não há elementos a serem estudados 


FICHA N $^{\circ} \quad 040 \quad$ data $26 / 02 / 2004$

AUTOR: GILBERTO FREYRE

TÍTULO DA OBRA: O VELHO FÉLIX E SUAS MEMÓRIAS DE UM CAVALCANTI EDIÇÃO: $1^{\mathrm{a}}$

LOCAL DE PUBLICAÇÃO: Rio de Janeiro

EDITORA: José Olympio/1959

DATA DA $1^{\text {a }}$ EDIÇÀO: 1940

PROSA ( $X$ ) POESIA ( )

PERSONAGEM: JUDIA（） ESTRANGEIRA（）

REFERÊNCIAS: A PERSONAGENS OU PESSOAS JUDIAS $(X)$

A PERSONAGENS OU PESSOAS ESTRANGEIRAS $(X)$

REFERÊNCIAS: A CULTURA JUDAICA（）

A CULTURA ESTRANGEIRA $(X)$

REFERÊNCIAS: INTERTEXTUAIS（） TEXTUAIS（）

SE SIM, QUAIS?

CARACTERÍSTICAS DA PERSONAGEM JUDIA:

- NOME:

- CARACTERÍSTICAS FÍSICAS:

A REFERÊNCIA APARECE:

- CAPÍTULO(s) Introdução e $2^{\circ}$ cap.

- PÁGINA(s) L, CXIV, CXV, CXVI, CXVII, CXVIII, CXX, CXXI, CXXII, CXXV e 46 OBSERVAÇÕES ESPECÍFICAS:

Na primeira edição o título era apenas Memórias de um Cavalcanti. Na introdução utiliza a seguinte expressão "... o próprio bolo de tabuleiro da negra limpa...".

Na página CXIV, comenta sobre a prostituição e o "caftismo" e fala de uma obra escrita no Rio de Janeiro em 1896, por Ferreira da Rosa, intitulada O Lupanar: estudo sôbre o caftismo e a prostituição no Rio de Janeiro. Nesta obra Ferreira da Rosa aborda um certo "Adolpho Abramowitz - especializados em escrever em hebraico cartas em que prostitutas austríacas, russas, polonesas, turcas quase iletradas, exploradas no Brasil por caftens seus compatriotas, ...."

Fala também sobre Jacob lacowitz e seu filho Salomão, ambos caftens no Brasil. Cita também sobre uma carta escrita por uma destas meninas enganadas, que escreve aos pais e esconde sua condição de prostituta.

Outras pessoas também são citadas todas vivendo da prostituição no Brasil. Dando ao leitor um certo panorama da realidade sobre a prostituição de moças judias no Brasil. 


$\begin{array}{llll}\text { FICHA N }^{\circ} & 041 & \text { data } & 10 / 03 / 2004\end{array}$

AUTOR: DR. LUIZ RIBEIRO DO VALLE

TÍTULO DA OBRA: CERTOS ESCRITORES BRASILEIROS PSYCHO - PATHOLOGISTAS EDIÇÃO: $1^{\mathrm{a}}$

LOCAL DE PUBLICAÇÃO: Rio de Janeiro

EDITORA: Typ. Lith. Pimenta de Mello \& C.

DATA DA $1^{\text {a }}$ EDIÇÀO: 1921

PROSA ( $X$ ) POESIA ( )

PERSONAGEM: JUDIA（） ESTRANGEIRA（）

REFERÊNCIAS: A PERSONAGENS OU PESSOAS JUDIAS ( $X$ )

A PERSONAGENS OU PESSOAS ESTRANGEIRAS $(X)$

REFERÊNCIAS: A CULTURA JUDAICA ( )

A CULTURA ESTRANGEIRA $(X)$

REFERÊNCIAS: INTERTEXTUAIS（） TEXTUAIS ( $X)$

SE SIM, QUAIS?

De diversos autores brasileiros e estrangeiros e célebres pensadores

\section{CARACTERÍSTICAS DA PERSONAGEM JUDIA:}

- NOME:

- CARACTERÍSTICAS FÍSICAS:

\section{A REFERÊNCIA APARECE:}

- CAPÍTULO(s)

- PÁGINA(s)

\section{OBSERVAÇÕES ESPECÍFICAS:}

Não há elementos a serem estudados da cultura judaica. Apenas existem pequenas citações de Israel Bernstein e Ibsen.

O livro possui muitas referências às culturas francesa e japonesa.

Entre as citações há: Balzac, Zola, Darwin, Shakespeare entre outros. 


\section{FICHA N $^{\circ} \quad 042 \quad$ data $20 / 03 / 2004$}

AUTOR: TASSO DE OLIVEIRA

TÍTULO DA OBRA: 30 ESPÍRITOS - FONTES

EDIÇÃO: $1^{\mathrm{a}}$

LOCAL DE PUBLICAÇÃO: Rio de Janeiro

EDITORA: Schmidt - Editor

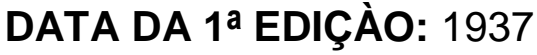

PROSA ( $X$ ) POESIA ( )

PERSONAGEM: JUDIA（） ESTRANGEIRA（）

REFERÊNCIAS: A PERSONAGENS OU PESSOAS JUDIAS ( $X$ )

A PERSONAGENS OU PESSOAS ESTRANGEIRAS ( $X$ )

REFERÊNCIAS: A CULTURA JUDAICA（）

A CULTURA ESTRANGEIRA ( $X$ )

REFERÊNCIAS: INTERTEXTUAIS（） TEXTUAIS ( $X$ )

SE SIM, QUAIS?

De vários autores entre eles Baudelaire, Goethe, Kant, Descartes e outros

\section{CARACTERÍSTICAS DA PERSONAGEM JUDIA:}

- NOME:

- CARACTERÍSTICAS FÍSICAS:

\section{A REFERÊNCIA APARECE:}

- CAPÍTULO(s) Defesa de Max Jacob; Algumas Notas Sobre Stefan Zweig e Baruch Spinoza

- PÁGINA(s) 75 à 81; 83 à 90, 100, 156, 157 e de 235 à 243

OBSERVAÇÕES ESPECÍFICAS:

Comenta sobre Stefan Zweig suas qualidades, valores e a popularidade de sua obra.

Na página 156 fala do movimento racista de Hitler, na pág. 157 cita a herança judaica no pensamento de Fichte e Hegel. 
DEPARTAMENTO DE LETRAS ORIENTAIS

FICHA No $043 \quad$ data $01 / 04 / 2004$

AUTOR: CASTRO ALVES

TÍTULO DA OBRA: CASTRO ALVES APOLOGIA E CRÍTICA: revista da Academia Brasileira de Letras - comemoração do cinquentenário do poeta

EDIÇÃO: $1^{\text {a }}$

LOCAL DE PUBLICAÇÃO: Rio de Janeiro

EDITORA: Francisco Alves

DATA DA $1^{\text {a }}$ EDIÇÀO: 1921

PROSA ( $X$ ) POESIA ( $X)$

PERSONAGEM: JUDIA（） ESTRANGEIRA（）

REFERÊNCIAS: A PERSONAGENS OU PESSOAS JUDIAS $(X)$

A PERSONAGENS OU PESSOAS ESTRANGEIRAS $(X)$

REFERÊNCIAS: A CULTURA JUDAICA ( $X$ )

A CULTURA ESTRANGEIRA ( $X$ )

REFERÊNCIAS: INTERTEXTUAIS（） TEXTUAIS ( $X)$

SE SIM, QUAIS?

Paradiso XXX, 21, 28 -30 de Dante e Macbeth de Shakespeare

CARACTERÍSTICAS DA PERSONAGEM JUDIA:

- NOME:

- CARACTERÍSTICAS FÍSICAS:

A REFERÊNCIA APARECE:

- CAPÍTULO(s)

- PÁGINA(s) 84 e 119

OBSERVAÇÕES ESPECÍFICAS:

Merece destaque o comentário sobre o poema "Hebreá" na página 84 e na página 119 o poeta Luiz Guimaraes Junior inseriu uma poesia de sua autoria intitutalada "Ao Poeta da Hebreá" e que já havia sido publica no jornal "Diário de Notícias" da Bahia. 
AUTOR: AMADEU AMARAL

TÍTULO DA OBRA: LETRAS FLORIDAS

EDIÇÃO: $1^{\mathrm{a}}$

LOCAL DE PUBLICAÇÃO: Rio de Janeiro

EDITORA: Leite Ribeiro \& Maurillo

DATA DA $1^{\text {a }}$ EDIÇÀO: 1920

PROSA ( $X$ ) POESIA ( $X$ )

PERSONAGEM: JUDIA（） ESTRANGEIRA（）

REFERÊNCIAS: A PERSONAGENS OU PESSOAS JUDIAS ( )

A PERSONAGENS OU PESSOAS ESTRANGEIRAS $(X)$

REFERÊNCIAS: A CULTURA JUDAICA（）

A CULTURA ESTRANGEIRA ( $X$ )

REFERÊNCIAS: INTERTEXTUAIS ( $X$ ) TEXTUAIS ( $X$ )

SE SIM, QUAIS?

Há referências textuais e intertextuais de escritores franceses e brasileiros

CARACTERÍSTICAS DA PERSONAGEM JUDIA:

- NOME:

- CARACTERÍSTICAS FÍSICAS:

A REFERÊNCIA APARECE:

- CAPÍTULO(s)

- PÁGINA(s)

OBSERVAÇÕES ESPECÍFICAS:

Há muitas referências às culturas francesas e grega 


\section{$\begin{array}{llll}\text { FICHA N }^{\circ} & 045 & \text { data } & 20 / 04 / 2004\end{array}$}

AUTOR: CONSTÂNCIO ALVES

TÍTULO DA OBRA: FIGURAS: edição do Annuario do Brasil

EDIÇÃO: $1^{\mathrm{a}}$

LOCAL DE PUBLICAÇÃO: Rio de Janeiro

EDITORA: Almanak Laemmert

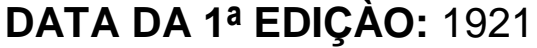

PROSA ( $X$ ) POESIA ( )

PERSONAGEM: JUDIA（） ESTRANGEIRA（）

REFERÊNCIAS: A PERSONAGENS OU PESSOAS JUDIAS ( $X$ )

A PERSONAGENS OU PESSOAS ESTRANGEIRAS $(X)$

REFERÊNCIAS: A CULTURA JUDAICA ( $X$ )

A CULTURA ESTRANGEIRA $(X)$

REFERÊNCIAS: INTERTEXTUAIS（） TEXTUAIS（）

SE SIM, QUAIS?

\section{CARACTERÍSTICAS DA PERSONAGEM JUDIA:}

- NOME:

- CARACTERÍSTICAS FÍSICAS:

\section{A REFERÊNCIA APARECE:}

- CAPÍTULO(s) Paulo Stapfer (sobre)

- PÁGINA(s) 110

\section{OBSERVAÇÕES ESPECÍFICAS:}

A obra é composta de textos escritos entre 1891 e 1921, comentando a literatura brasileira e universal, havendo portanto menções a vários autores, como: Victor Hugo, Bartolomeu Mitre, Musset, Byron, Edgard A. Poe e outros.

Na pág, 110 aborda o caso Dreyfus, comentando sobre o judeu caluniado e amigo de Paulo Stapfer (texto escrito em 29/03/1917). 


\section{FICHA N $^{\circ} 046 \quad$ data $02 / 05 / 2004$}

AUTOR: GILBERTO FREYRE

TÍTULO DA OBRA: O MUNDO QUE O PORTUGUÊS CRIOU

EDIÇÃO: $2^{\mathrm{a}}$

LOCAL DE PUBLICAÇÃO: Rio de Janeiro

EDITORA: José Olympio

DATA DA $1^{\text {a }}$ EDIÇÀO: 1938

PROSA ( $X$ ) POESIA ( )

PERSONAGEM: JUDIA（） ESTRANGEIRA（）

REFERÊNCIAS: A PERSONAGENS OU PESSOAS JUDIAS ( $X$ )

A PERSONAGENS OU PESSOAS ESTRANGEIRAS $(X)$

REFERÊNCIAS: A CULTURA JUDAICA ( $X$ )

A CULTURA ESTRANGEIRA ( $X$ )

REFERÊNCIAS: INTERTEXTUAIS（） TEXTUAIS（）

SE SIM, QUAIS?

\section{CARACTERÍSTICAS DA PERSONAGEM JUDIA:}

- NOME:

- CARACTERÍSTICAS FÍSICAS:

\section{A REFERÊNCIA APARECE:}

- CAPÍTULO(s) Prefácio, Introdução

- PÁGINA(s) 14, 36, 37, 40, 72, 90, 91, 113, 117 à 119, 124 e 155

OBSERVAÇÕES ESPECÍFICAS:

O texto do livro foi originalmente escrito para ser apresentado em conferências, lidas na Universidade de Londres(King's College), em 1937. Ganhou o formato de livro e o título apenas em 1940.

Destauqe para a pluralidade de culturas que o autor faz questão de frisar, dos imigrantes das mais diversas origens(alemães, japoneses, judeus, poloneses, italianos e outros).

Menciona Franz Boas, Claude Lévy Strauss e o prof. Merville J. Herskovits (intelectuais de destaque e membros da comunidade judaica).

Nas pág 113, 117 á 119 e 124 volta-se contra o judeu, reforçando os esteriótipos de comerciante internacional e a atraçào dos judeus pela América, entre outros. 


\section{FICHA N $^{\circ} \quad 047 \quad$ data $20 / 05 / 2004$}

AUTOR: GILBERTO FREYRE

TÍTULO DA OBRA: RETALHOS DE JORNAIS VELHOS

EDIÇÃO: $1^{\mathrm{a}}$

LOCAL DE PUBLICAÇÃO: Rio de Janeiro

EDITORA: José Olympio

DATA DA 1 ${ }^{\text {a }}$ EDIÇÀO: 1935

PROSA ( $X$ ) POESIA ( )

PERSONAGEM: JUDIA（） ESTRANGEIRA（）

REFERÊNCIAS: A PERSONAGENS OU PESSOAS JUDIAS ( $X$ )

A PERSONAGENS OU PESSOAS ESTRANGEIRAS $(X)$

REFERÊNCIAS: A CULTURA JUDAICA（）

A CULTURA ESTRANGEIRA ( $X$ )

REFERÊNCIAS: INTERTEXTUAIS（） TEXTUAIS ( $X$ )

SE SIM, QUAIS?

Cita frases de Adam Smith

\section{CARACTERÍSTICAS DA PERSONAGEM JUDIA:}

- NOME:

- CARACTERÍSTICAS FÍSICAS:

\section{A REFERÊNCIA APARECE:}

- CAPÍTULO(s)

- PÁGINA(s) 63, 195, 106, 119, 143 e 151

OBSERVAÇÕES ESPECÍFICAS:

O autor menciona diversas personalidades internacionais como: Augusto Comte, Goethe, Napoleão, Mussolini e também Eistein Franz Boas e outros.

Na pág 119 comenta a visita que Eistein fizera ao Brasil e na pág 143 fala de jesus e o ponto de vista de um judeu no período bíblico.

Na pág 151 comenta sobre Leopold Bloom, um judeu que vivia emDublin.

Todo o texto do livro foram escritos originalmente para o jornal Diário de Pernambuco, pelo autor entre os anos de 1922 e 1925. por serem matérias jornalísticas expressão muito do que acontecia no período e fatos reais da história. 


$\begin{array}{llll}\text { FICHA N }^{\circ} & 048 & \text { data } & 01 / 06 / 2004\end{array}$

AUTOR: ARTHUR MOTTA

TíTULO DA OBRA: JOSÉ DE ALENCAR: O ESCRITOR E O POLÍTICO

EDIÇÃO: $1^{\mathrm{a}}$

LOCAL DE PUBLICAÇÃO: Rio de Janeiro

EDITORA: F. Briguiet \& Cia

DATA DA 1ª EDIÇÀO: 1921

PROSA ( $X$ ) POESIA ( $X)$

PERSONAGEM: JUDIA（） ESTRANGEIRA（）

REFERÊNCIAS: A PERSONAGENS OU PESSOAS JUDIAS ( )

A PERSONAGENS OU PESSOAS ESTRANGEIRAS ( $X$ )

REFERÊNCIAS: A CULTURA JUDAICA（ )

A CULTURA ESTRANGEIRA ( $X$ )

REFERÊNCIAS: INTERTEXTUAIS（） TEXTUAIS ( $X$ )

SE SIM, QUAIS?

Existem várias referências textuais(em francês), sobre a literatura francesa. Do autor Tayne há referências extraídas de a Histoire de la litterature anglaise e do autor Anatole France

CARACTERÍSTICAS DA PERSONAGEM JUDIA:

- NOME:

- CARACTERÍSTICAS FÍSICAS:

A REFERÊNCIA APARECE:

- CAPÍtUlo(s)

- PÁGINA(s)

OBSERVAÇÕES ESPECÍFICAS:

Não há elementos a serem estudados sobre os judeus e a cultura judaica. 


\section{FICHA N $^{\circ} \quad 049 \quad$ data $15 / 06 / 2004$}

AUTOR: MARIO CASASANTA

TÍTULO DA OBRA: MINAS E OS MINEIROS NA OBRA DE MACHADO DE ASSIS EDIÇÃO: $1^{\mathrm{a}}$

LOCAL DE PUBLICAÇÃO: Belo Horizonte

EDITORA: Amigos do livro

DATA DA 1ª EDIÇÀO: 1932

PROSA (X ) POESIA ( )

PERSONAGEM: JUDIA（） ESTRANGEIRA（）

REFERÊNCIAS: A PERSONAGENS OU PESSOAS JUDIAS ( )

A PERSONAGENS OU PESSOAS ESTRANGEIRAS ( $X$ )

REFERÊNCIAS: A CULTURA JUDAICA（ )

A CULTURA ESTRANGEIRA $(X)$

REFERÊNCIAS: INTERTEXTUAIS（） TEXTUAIS ( $X$ )

SE SIM, QUAIS?

Do próprio Machado de Assis e sua obra

CARACTERÍSTICAS DA PERSONAGEM JUDIA:

- NOME:

- CARACTERÍSTICAS FÍSICAS:

A REFERÊNCIA APARECE:

- CAPÍTULO(s)

- PÁGINA(s)

OBSERVAÇÕES ESPECÍFICAS:

Não há elementos a serem estudados que sejam relevantes para a pesquisa. Destaque para o comentário sobre a obra Esaú e Jacob, nas páginas 12, 54, 62, 63 e 66. 


\section{FICHA N $^{\circ} \quad 050 \quad$ data $30 / 06 / 2004$}

AUTOR: TEIXEIRA SOARES

TÍTULO DA OBRA: MACHADO DE ASSIS (ENSAIO E INTERPRETAÇÃO)

EDIÇÃO: $1^{\mathrm{a}}$

LOCAL DE PUBLICAÇÃO: Rio de Janeiro

EDITORA: Typ. Guido \& Cia.

DATA DA $1^{\text {a }}$ EDIÇÀO: 1936

PROSA (X) POESIA ( )

PERSONAGEM: JUDIA（） ESTRANGEIRA（）

REFERÊNCIAS: A PERSONAGENS OU PESSOAS JUDIAS ( )

A PERSONAGENS OU PESSOAS ESTRANGEIRAS $(X)$

REFERÊNCIAS: A CULTURA JUDAICA（）

A CULTURA ESTRANGEIRA ( $X$ )

REFERÊNCIAS: INTERTEXTUAIS（） TEXTUAIS ( $X$ )

SE SIM, QUAIS?

Do próprio Machado de Assis, de Aldous Huxley, da Bíblia e outras obras

CARACTERÍSTICAS DA PERSONAGEM JUDIA:

- NOME:

- CARACTERÍSTICAS FÍSICAS:

A REFERÊNCIA APARECE:

- CAPÍTULO(s)

- PÁGINA(s)

OBSERVAÇÕES ESPECÍFICAS:

Não há elementos a serem estudados que sejam relevantes a pesquisa.

O autor sempre compara Machado de Assis a Dickens e a Mark Twain, devido a mesma origem pobre destes escritores. 


\section{FICHA N $^{\circ} \quad 051 \quad$ data $09 / 07 / 2004$}

AUTOR: RUI RIBEIRO COUTO

TÍTULO DA OBRA: CHÃO DE FRANÇA

EDIÇÃO: $1^{\mathrm{a}}$

LOCAL DE PUBLICAÇÃO: São Paulo

EDITORA: Cia. Editora Nacional

DATA DA $1^{\text {a }}$ EDIÇÀO: 1935

PROSA ( $X$ ) POESIA ( )

PERSONAGEM: JUDIA（） ESTRANGEIRA（）

REFERÊNCIAS: A PERSONAGENS OU PESSOAS JUDIAS ( )

A PERSONAGENS OU PESSOAS ESTRANGEIRAS ( $X$ )

REFERÊNCIAS: A CULTURA JUDAICA ( $X$ )

A CULTURA ESTRANGEIRA $(X)$

REFERÊNCIAS: INTERTEXTUAIS（） TEXTUAIS（）

SE SIM, QUAIS?

CARACTERÍSTICAS DA PERSONAGEM JUDIA:

- NOME:

- CARACTERÍSTICAS FÍSICAS:

A REFERÊNCIA APARECE:

- CAPÍTULO(s) Avignon

- PÁGINA(s) 129, 136 e 143

OBSERVAÇÕES ESPECÍFICAS:

Na pág. 129 aparecem as palavras: sinagoga e israel; na pág. 136 fala da Inquisição e na pág. 143 aparece a palavra sabbat.

Apesar de aparecerem palavras que fazem parte da cultura e religião judaicas, estas palavras estão fora do contexto. 


\section{FICHA N $^{\circ} \quad 052 \quad$ data $27 / 07 / 2004$}

AUTOR: RENÉ THIOLLIER

TíTULO DA OBRA: O HOMEM DA GALERIA (ECHOS DE UMA ÉPOCA)

EDIÇÃO: $1^{\mathrm{a}}$

LOCAL DE PUBLICAÇÃO: São Paulo

EDITORA: Livraria Teixeira

DATA DA 1ª EDIÇÀO: 1927

PROSA ( $X$ ) POESIA ( )

PERSONAGEM: JUDIA（） ESTRANGEIRA（）

REFERÊNCIAS: A PERSONAGENS OU PESSOAS JUDIAS ( $X$ )

A PERSONAGENS OU PESSOAS ESTRANGEIRAS ( $X$ )

REFERÊNCIAS: A CULTURA JUDAICA（ )

A CULTURA ESTRANGEIRA ( $X$ )

REFERÊNCIAS: INTERTEXTUAIS ( X ) TEXTUAIS ( )

SE SIM, QUAIS?

De Saint Jean Chrysostome (versos em francês) e de Seneca (em latim)

CARACTERÍSTICAS DA PERSONAGEM JUDIA:

- NOME:

- CARACTERÍSTICAS FÍSICAS:

\section{A REFERÊNCIA APARECE:}

- CAPÍTULO(s)

- PÁGINA(s)

OBSERVAÇÕES ESPECÍFICAS:

Mencionao o nome de algumas personalidades nacionais e internacionais. Entre as nacionais está Lasar Segall, artista plástico, judeu, radicado no Brasil. Das personalidades internacionais estão Picasso, Goethe, Anatole France, Victor Hugo entre outros. 
DEPARTAMENTO DE LETRAS ORIENTAIS

FICHA No 053 data $04 / 08 / 2004$

AUTOR: RENÉ THIOLLIER

TÍTULO DA OBRA: SR. DOM TORRES - PÁGINAS AGRODOCES

EDIÇÃO: $1^{\mathrm{a}}$

LOCAL DE PUBLICAÇÃO: São Paulo

EDITORA: Casa Mavença

DATA DA $1^{\text {a }}$ EDIÇÀO: 1921

PROSA (X ) POESIA ( )

PERSONAGEM: JUDIA（） ESTRANGEIRA ( $X$ )

REFERÊNCIAS: A PERSONAGENS OU PESSOAS JUDIAS $(X)$

A PERSONAGENS OU PESSOAS ESTRANGEIRAS $(X)$

REFERÊNCIAS: A CULTURA JUDAICA（ )

A CULTURA ESTRANGEIRA $(X)$

REFERÊNCIAS: INTERTEXTUAIS（） TEXTUAIS ( $X$ )

SE SIM, QUAIS?

De Montesquieu (Lettres Persones), de Montaigne, Sêneca (Cartas a Luciluis) e de Anatole France

CARACTERÍSTICAS DA PERSONAGEM JUDIA:

- NOME:

- CARACTERÍSTICAS FÍSICAS:

A REFERÊNCIA APARECE:

- CAPÍTULO(s)

- PÁGINA(s)

OBSERVAÇÕES ESPECÍFICAS:

Não há elementos da cultura e/ou religião judaicas no texto, apenas menciona o nome de Rockefeller.

Há um personagem que é um açogueiro italiano que possui como característica pessoa não gostar de negros. Também há um personagem que é um japonês que trabalha como criado de uma casa.

Na página 247 fala de uma pensão de imigrantes e da falta do hábito de tomar banho destes mesmos imigrantes. 


\section{$\begin{array}{lll}\text { FICHA No }^{\circ} & 054 \quad \text { data } 30 / 08 / 2004\end{array}$}

AUTOR: RUI RIBEIRO COUTO

TÍTULO DA OBRA: JARDIM DAS CONFIDÊNCIAS

EDIÇÃO: $1^{\mathrm{a}}$

LOCAL DE PUBLICAÇÃO: São Paulo

EDITORA: Monteiro Lobato \& Cia.

DATA DA $1^{\text {a }}$ EDIÇÀO: 1921

PROSA（） POESIA ( $X)$

PERSONAGEM: JUDIA（） ESTRANGEIRA（）

REFERÊNCIAS: A PERSONAGENS OU PESSOAS JUDIAS ( )

A PERSONAGENS OU PESSOAS ESTRANGEIRAS（）

REFERÊNCIAS: A CULTURA JUDAICA（ )

A CULTURA ESTRANGEIRA（）

REFERÊNCIAS: INTERTEXTUAIS（） TEXTUAIS（）

SE SIM, QUAIS?

CARACTERÍSTICAS DA PERSONAGEM JUDIA:

- NOME:

- CARACTERÍSTICAS FÍSICAS:

A REFERÊNCIA APARECE:

- CAPÍTULO(s)

- PÁGINA(s)

OBSERVAÇÕES ESPECÍFICAS:

Não há elementos a serem estudados que sejam relevantes para a pesquisa. 


\begin{tabular}{rrr}
\hline FICHA No & 055 data $10 / 09 / 2004$
\end{tabular}

AUTOR: SERGIO MILLIET

TÍTULO DA OBRA: MARCHA A RÉ

EDIÇÃO: $1^{\mathrm{a}}$

LOCAL DE PUBLICAÇÃO: São Paulo

EDITORA: José Olympio

DATA DA $1^{\text {a }}$ EDIÇÀO: 1936

PROSA ( $X$ ) POESIA ( )

PERSONAGEM: JUDIA（） ESTRANGEIRA（）

REFERÊNCIAS: A PERSONAGENS OU PESSOAS JUDIAS $(X)$

A PERSONAGENS OU PESSOAS ESTRANGEIRAS $(X)$

REFERÊNCIAS: A CULTURA JUDAICA（）

A CULTURA ESTRANGEIRA $(X)$

REFERÊNCIAS: INTERTEXTUAIS（） TEXTUAIS ( $X$ )

SE SIM, QUAIS?

Do líder indiano Ghandi

CARACTERÍSTICAS DA PERSONAGEM JUDIA:

- NOME:

- CARACTERÍSTICAS FÍSICAS:

\section{A REFERÊNCIA APARECE:}

- CAPÍTULO(s)

- PÁGINA(s) 98, 103 e 133

OBSERVAÇÕES ESPECÍFICAS:

A obra é composta de crônicas da época, são mencionadas diversas personalidades internacionais como: Freud, Baudelaire, Anatole France, Goethe, Byron e outros. Entre as personalidades mencionadas estão Einstein (pág. 98).

Na pág. 103 fala sobre o caso Dreyffus e na pág. 133 aborda o nazismo e o facismo, deixando claro ser contra estas ideologias e forma de governar. 


\section{FICHA No $056 \quad$ data $02 / 10 / 2004$}

AUTOR: ALBERTO DE OLIVEIRA e JORGE JOBIM

TÍTULO DA OBRA: MACHADO DE ASSIS

EDIÇÃO: $1^{\mathrm{a}}$

LOCAL DE PUBLICAÇÃO: Rio de Janeiro

EDITORA: Livraria Garnier

DATA DA $1^{\text {a }}$ EDIÇÀO: 1921

PROSA ( $X$ ) POESIA ( )

PERSONAGEM: JUDIA（） ESTRANGEIRA（）

REFERÊNCIAS: A PERSONAGENS OU PESSOAS JUDIAS ( )

A PERSONAGENS OU PESSOAS ESTRANGEIRAS ( $X$ )

REFERÊNCIAS: A CULTURA JUDAICA（）

A CULTURA ESTRANGEIRA $(X)$

REFERÊNCIAS: INTERTEXTUAIS（） TEXTUAIS ( $X$ )

SE SIM, QUAIS?

Nas pág. 380 até 385 foi inserido o discurso que Ruy Barbosa proferiu em 09/10/1908 a beira do ataude de Machado de Assis.

\section{CARACTERÍSTICAS DA PERSONAGEM JUDIA:}

- NOME:

- CARACTERÍSTICAS FÍSICAS:

\section{A REFERÊNCIA APARECE:}

- CAPÍTULO(s)

- PÁGINA(s)

OBSERVAÇÕES ESPECÍFICAS:

Foram analisadas apenas as páginas onde os autores tecem uma introdução sobre Machado de Assis e as análises sobre o mesmo.

O restante da obra, cerca de $80 \%$, não foi estudada em virtude de ser composta pelos textos de Machado, que não pertencem ao período desta pesquisa. 


\begin{tabular}{|lll|}
\hline FICHA No & 057 & data $09 / 10 / 2004$ \\
\hline
\end{tabular}

AUTOR: AFRÂNIO PEIXOTO

TÍTULO DA OBRA: CASTRO ALVES: O POETA E O POEMA

EDIÇÃO: $1^{\mathrm{a}}$

LOCAL DE PUBLICAÇÃO: Lisboa

EDITORA: Livraria Aillaud e Bertrand

DATA DA $1^{\text {a }}$ EDIÇÀO: 1922

PROSA ( $X$ ) POESIA ( )

PERSONAGEM: JUDIA（） ESTRANGEIRA（）

REFERÊNCIAS: A PERSONAGENS OU PESSOAS JUDIAS $(X)$

A PERSONAGENS OU PESSOAS ESTRANGEIRAS $(X)$

REFERÊNCIAS: A CULTURA JUDAICA ( $X$ )

A CULTURA ESTRANGEIRA $(X)$

REFERÊNCIAS: INTERTEXTUAIS（） TEXTUAIS ( $X$ )

SE SIM, QUAIS?

Do próprio Castro Alves, pois são extraídos pequenos fragmentos de sua obra para serem analisados.

\section{CARACTERÍSTICAS DA PERSONAGEM JUDIA:}

- NOME:

- CARACTERÍSTICAS FÍSICAS:

\section{A REFERÊNCIA APARECE:}

- CAPÍTULO(s)

- PÁGINA(s) 22, 52, 54, 154, 155, 276

OBSERVAÇÕES ESPECÍFICAS:

Na pág. 22 menciona uma poesia intitulada $A$ Destruição de Jerusalém, de Castro Alves; na pág. 52 comenta sobre um verso de Castro Alves onde aparece escrito: Moisés no Sinai; na pág. 54 comenta sobre outro poema que aparece a frase: Sou hebreu........ não beijo as plantas; nas páginas 153 e 154 o autor fala do namoro de Castro Alves com duas moças judias da família Amzalack, sobre o poema A Hebréia e sobre uma prima destas moças, chamada Esther que vivia em Lisboa e foi musa inspiradora do poeta Tomás Ribeiro, por volta de 1867; na pág. 276 volta a falar desta mesma Esther. 


\section{FICHA N $^{\circ} \quad 058 \quad$ data $10 / 11 / 2004$}

AUTOR: AFFONSO SCHMIDT

TÍTULO DA OBRA: MOCIDADE

EDIÇÃO: $1^{\mathrm{a}}$

LOCAL DE PUBLICAÇÃO: Santos/SP

EDITORA: Typographia Instituto

DATA DA 1ª EDIÇÀO: 1921

PROSA ( ) POESIA ( $X$ )

PERSONAGEM: JUDIA（） ESTRANGEIRA（）

REFERÊNCIAS: A PERSONAGENS OU PESSOAS JUDIAS ( )

A PERSONAGENS OU PESSOAS ESTRANGEIRAS ( $X$ )

REFERÊNCIAS: A CULTURA JUDAICA（ )

A CULTURA ESTRANGEIRA ( $X$ )

REFERÊNCIAS: INTERTEXTUAIS ( $X$ ) TEXTUAIS ( )

SE SIM, QUAIS?

Com antigas cantigas de roda

CARACTERÍSTICAS DA PERSONAGEM JUDIA:

- NOME:

- CARACTERÍSTICAS FÍSICAS:

A REFERÊNCIA APARECE:

- CAPÍtUlo(s)

- PÁGINA(s) 14 e 20

OBSERVAÇÕES ESPECÍFICAS:

Há referências sobre a cultura alemã e francesa. Faz um pequeno comentário sobre o personagem Dom Quixote.

Na página 14 aparece a palavra cabala e na 20 fala de Jerusalém, mas aparecem descontextualizadas. 


\section{FICHA N N $^{\circ} 059 \quad$ data $19 / 11 / 2004$}

AUTOR: ALFREDO D'ESCRAGNOLLE TAUNAY (VISCONDE DE TAUNAY)

TÍTULO DA OBRA: PHILOLOGIA E CRÍTICA

EDIÇÃO: $1^{\mathrm{a}}$

LOCAL DE PUBLICAÇÃO: São Paulo

EDITORA: Melhoramentos

DATA DA 1ª EDIÇÀO: 1921

PROSA ( $X$ ) POESIA ( )

PERSONAGEM: JUDIA（） ESTRANGEIRA（）

REFERÊNCIAS: A PERSONAGENS OU PESSOAS JUDIAS ( )

A PERSONAGENS OU PESSOAS ESTRANGEIRAS ( $X$ )

REFERÊNCIAS: A CULTURA JUDAICA ( $X$ )

A CULTURA ESTRANGEIRA ( $X$ )

REFERÊNCIAS: INTERTEXTUAIS（） TEXTUAIS ( $X$ )

SE SIM, QUAIS?

Padre Antonio Vieira e demais escritores analisados na II parte do livro: Crítica. Entre eles estão: Émile Zolá, Victor Hugo, A. Dumas Filho, Anatole France, Proust e outros.

\section{CARACTERÍSTICAS DA PERSONAGEM JUDIA:}

- NOME:

- CARACTERÍSTICAS FÍSICAS:

\section{A REFERÊNCIA APARECE:}

- CAPÍTULO(s) Anatole France - L'orme du mail

- PÁGINA(s) 105, 106 e 121

\section{OBSERVAÇÕES ESPECÍFICAS:}

Nas pág. 105 e 106 comenta um dos personagens de A. France e aparece o seguinte trecho: “... o prefeito sobretudo, mescla de judaísmo e irônica descrença, ..." ; na pág. 121 comenta sobre Baruch, um profeta bíblico e a Rainha de Sabá. 


FICHA No 060 data $23 / 11 / 2004$

AUTOR: LUIZ DA CÂMARA CASCUDO

TÍTULO DA OBRA: ALMA PATRÍCIA: CRÍTICA LITTERÁRIA

EDIÇÃO: $1^{\mathrm{a}}$

LOCAL DE PUBLICAÇÃO: Natal/RN

EDITORA: A. Câmara \& Cia.

DATA DA $1^{\text {a }}$ EDIÇÀO: 1921

PROSA ( $X$ ) POESIA ( )

PERSONAGEM: JUDIA（） ESTRANGEIRA（）

REFERÊNCIAS: A PERSONAGENS OU PESSOAS JUDIAS $(X)$

A PERSONAGENS OU PESSOAS ESTRANGEIRAS $(X)$

REFERÊNCIAS: A CULTURA JUDAICA ( $X$ )

A CULTURA ESTRANGEIRA $(X)$

REFERÊNCIAS: INTERTEXTUAIS（） TEXTUAIS（）

SE SIM, QUAIS?

CARACTERÍSTICAS DA PERSONAGEM JUDIA:

- NOME:

- CARACTERÍSTICAS FÍSICAS:

\section{A REFERÊNCIA APARECE:}

- CAPÍTULO(s)

- PÁGINA(s) 21 e 34

OBSERVAÇÕES ESPECÍFICAS:

Esta obra trata-se de um compêndio sobre os escritores e jornalistas do Rio Grande do Norte, o autor também fala sobre inúmeros autores e personagens da literatura universal, entre eles Spinoza.

Na pág. 21 aparece a frase: "Uma cruzada digna, um pouco d'alma eternamente jovem da Hollanda de Spinoza.....".

Na pág 34 mencioa a poesia Judia de Thomaz Ribeiro (poeta português cuja musa inspiradora era a jovem Esther, ambos mencinados na obra Castro Alves: o poeta e o poema de Afrânio Peixoto, ficha $n^{\circ}$ 057) 


\begin{tabular}{|ccc|}
\hline FICHA No & 061 & data $24 / 11 / 2004$ \\
\hline
\end{tabular}

AUTOR: VISCONDE DE TAUNAY

TÍTULO DA OBRA: CARTAS DA CAMPANHA: A CORDILHEIRA - AGONIA DE LOPEZ (1869-1870)

EDIÇÃO: $1^{\mathrm{a}}$

LOCAL DE PUBLICAÇÃO: São Paulo

EDITORA: Melhoramentos

DATA DA $1^{\text {a }}$ EDIÇÀO: 1921

PROSA (X ) POESIA ( )

PERSONAGEM: JUDIA（） ESTRANGEIRA（）

REFERÊNCIAS: A PERSONAGENS OU PESSOAS JUDIAS ( )

A PERSONAGENS OU PESSOAS ESTRANGEIRAS ( $X$ )

REFERÊNCIAS: A CULTURA JUDAICA（ )

A CULTURA ESTRANGEIRA ( $X$ )

REFERÊNCIAS: INTERTEXTUAIS（）TEXTUAIS（）

SE SIM, QUAIS?

CARACTERÍSTICAS DA PERSONAGEM JUDIA:

- NOME:

- CARACTERÍSTICAS FÍSICAS:

A REFERÊNCIA APARECE:

- CAPÍTULO(s)

- PÁGINA(s)

OBSERVAÇÕES ESPECÍFICAS:

Não há elementos a serem estudados que sejam importantes para a pesquisa.

Destauqe para o fato do autor conta sobre a Guerra do Paraguai, fala muito mal de Solano Lopez e do filho deste, Pancho Lopez e de outros líderes paraguaios. 


\section{FICHA N $^{\circ} 062 \quad$ data $01 / 12 / 2004$}

AUTOR: ROSALINA COELHO LISBOA

TÍTULO DA OBRA: RITO PAGÃO

EDIÇÃO: $1^{\mathrm{a}}$

LOCAL DE PUBLICAÇÃO: São Paulo

EDITORA: Oficinas Gráphicas Monteiro Lobato \& Cia.

DATA DA 1ª EDIÇÀO: 1921

PROSA（ ) POESIA ( X )

PERSONAGEM: JUDIA（） ESTRANGEIRA（）

REFERÊNCIAS: A PERSONAGENS OU PESSOAS JUDIAS ( )

A PERSONAGENS OU PESSOAS ESTRANGEIRAS ( )

REFERÊNCIAS: A CULTURA JUDAICA（ )

A CULTURA ESTRANGEIRA ( $X$ )

REFERÊNCIAS: INTERTEXTUAIS（） TEXTUAIS ( $X$ )

SE SIM, QUAIS?

De Dante Alighieri, Omar Khayyám e Wagner

CARACTERÍSTICAS DA PERSONAGEM JUDIA:

- NOME:

- CARACTERÍSTICAS FÍSICAS:

A REFERÊNCIA APARECE:

- CAPÍTULO(s)

- PÁGINA(s)

OBSERVAÇÕES ESPECÍFICAS:

Há referências às culturas italiana, inglesa e Indiana. Quanto a esta última, merece destaque o fato da autora inserir vários poemas que falam dos deuses e de hábitos indianos. 


\section{FICHA N N $^{\circ} 063 \quad$ data $03 / 12 / 2004$}

AUTOR: XAVIER MARQUES

TÍTULO DA OBRA: O SARGENTO PEDRO

EDIÇÃO: $2^{\mathrm{a}}$

LOCAL DE PUBLICAÇÃO: Salvador/BA

EDITORA: Livraria Catilina/1921

DATA DA $1^{\mathrm{a}}$ EDIÇÀO:

PROSA ( $X$ ) POESIA ( )

PERSONAGEM: JUDIA（） ESTRANGEIRA（）

REFERÊNCIAS: A PERSONAGENS OU PESSOAS JUDIAS ( )

A PERSONAGENS OU PESSOAS ESTRANGEIRAS ( $X$ )

REFERÊNCIAS: A CULTURA JUDAICA（ )

A CULTURA ESTRANGEIRA（）

REFERÊNCIAS: INTERTEXTUAIS（）TEXTUAIS（）

SE SIM, QUAIS?

CARACTERÍSTICAS DA PERSONAGEM JUDIA:

- NOME:

- CARACTERÍSTICAS FÍSICAS:

A REFERÊNCIA APARECE:

- CAPÍtUlo(s)

- PÁGINA(s)

OBSERVAÇÕES ESPECÍFICAS:

Trata os personagens portugueses como estrangeiros e perigosos, por conta da Independência brasileira ocorrida em 1822, possui todos os elementos de um romance épico. 


\section{FICHA N $^{\circ} \quad 064 \quad$ data $04 / 12 / 2004$}

AUTOR: VÁRIOS AUTORES

TÍTULO DA OBRA: FEIRA LITERÁRIA

EDIÇÃO: $1^{\mathrm{a}}$

LOCAL DE PUBLICAÇÃO: São Paulo

EDITORA: Divulgação Literária

DATA DA 1ª EDIÇÀO: 1929

PROSA ( $X$ ) POESIA ( $X)$

PERSONAGEM: JUDIA（） ESTRANGEIRA（）

REFERÊNCIAS: A PERSONAGENS OU PESSOAS JUDIAS ( )

A PERSONAGENS OU PESSOAS ESTRANGEIRAS ( $X$ )

REFERÊNCIAS: A CULTURA JUDAICA（ )

A CULTURA ESTRANGEIRA（）

REFERÊNCIAS: INTERTEXTUAIS（） TEXTUAIS (X)

SE SIM, QUAIS?

De Edgar Alan Pöe

CARACTERÍSTICAS DA PERSONAGEM JUDIA:

- NOME:

- CARACTERÍSTICAS FÍSICAS:

A REFERÊNCIA APARECE:

- CAPÍTULO(s)

- PÁGINA(s)

OBSERVAÇÕES ESPECÍFICAS:

A obra agrupa vários autores, com um formato de revista literária, em suas páginas haviam propagandas e era editada mensalmente, o exemplar lido era o de $\mathrm{n}^{\circ} 01$ de 1929.

Alguns autores publicavam textos em prosa, outros em poesia e até pequenas novelas. 


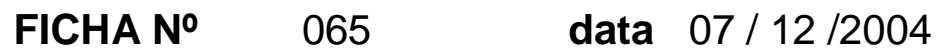

AUTOR: MARIO SETTE

TÍTULO DA OBRA: SENHORA DE ENGENHO

EDIÇÃO: $2^{\mathrm{a}}$

LOCAL DE PUBLICAÇÃO: Recife/PE

EDITORA: Imprensa Industrial/1921

DATA DA $1^{\mathrm{a}}$ EDIÇÀO:

PROSA (X ) POESIA ( )

PERSONAGEM: JUDIA（） ESTRANGEIRA（）

REFERÊNCIAS: A PERSONAGENS OU PESSOAS JUDIAS ( )

A PERSONAGENS OU PESSOAS ESTRANGEIRAS ( )

REFERÊNCIAS: A CULTURA JUDAICA ( $X$ )

A CULTURA ESTRANGEIRA（）

REFERÊNCIAS: INTERTEXTUAIS（） TEXTUAIS（）

SE SIM, QUAIS?

CARACTERÍSTICAS DA PERSONAGEM JUDIA:

- NOME:

- CARACTERÍSTICAS FÍSICAS:

A REFERÊNCIA APARECE:

- CAPÍTULO(s)

- PÁGINA(s) 32 e 116

OBSERVAÇÕES ESPECÍFICAS:

Na página 32 ao falar de Jesus e Maria um dos personagens remonta a origem judaica das figuras bíblicas.

Na página 116 a palavra judiarias como sinônimo de maus tratos. 


\begin{tabular}{|ccc|}
\hline FICHA No & 066 & data $10 / 12 / 2004$ \\
\hline
\end{tabular}

AUTOR: XAVIER MARQUES

TÍTULO DA OBRA: O FEITICEIRO

EDIÇÃO: $1^{\text {a }}$

LOCAL DE PUBLICAÇÃO: Rio de Janeiro

EDITORA: Livraria Editora Leite Ribeiro

DATA DA $1^{\text {a }}$ EDIÇÀO: 1922

PROSA ( $X$ ) POESIA ( )

PERSONAGEM: JUDIA（） ESTRANGEIRA（）

REFERÊNCIAS: A PERSONAGENS OU PESSOAS JUDIAS ( )

A PERSONAGENS OU PESSOAS ESTRANGEIRAS ( $X$ )

REFERÊNCIAS: A CULTURA JUDAICA ( $X$ )

A CULTURA ESTRANGEIRA（）

REFERÊNCIAS: INTERTEXTUAIS（） TEXTUAIS（）

SE SIM, QUAIS?

CARACTERÍSTICAS DA PERSONAGEM JUDIA:

- NOME:

- CARACTERÍSTICAS FÍSICAS:

A REFERÊNCIA APARECE:

- CAPÍTULO(s)

- PÁGINA(s) 41, 1144 e 269

OBSERVAÇÕES ESPECÍFICAS:

Na pág. 41 aparece a frase: "Mas o mysterio da cabala, os gestos do ritual, ... ......".

Na pág. 114: "... e os cabalistas de maior confiança dos chefes."

Percebe-se que o autor mistura cabala com magia. 


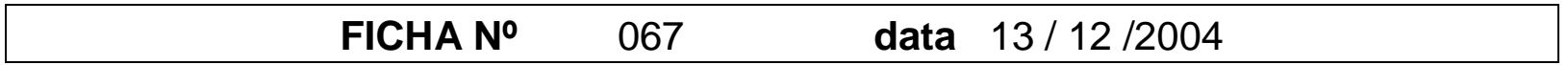

AUTOR: PAULO SETUBAL

TÍTULO DA OBRA: A MARQUEZA DE SANTOS

EDIÇÃO: $6^{\mathrm{a}}$

LOCAL DE PUBLICAÇÃO: São Paulo

EDITORA: Cia. Editora Nacional/1928

DATA DA 1ª EDIÇÀO: 1924

PROSA ( $X$ ) POESIA ( )

PERSONAGEM: JUDIA（） ESTRANGEIRA ( $X$ )

REFERÊNCIAS: A PERSONAGENS OU PESSOAS JUDIAS ( $X$ )

A PERSONAGENS OU PESSOAS ESTRANGEIRAS ( $X$ )

REFERÊNCIAS: A CULTURA JUDAICA（ )

A CULTURA ESTRANGEIRA ( $X$ )

REFERÊNCIAS: INTERTEXTUAIS（） TEXTUAIS ( X )

SE SIM, QUAIS?

Do jornal O Diário Fluminense

CARACTERÍSTICAS DA PERSONAGEM JUDIA:

- NOME:

- CARACTERÍSTICAS FÍSICAS:

\section{A REFERÊNCIA APARECE:}

- CAPÍTULO(s)

- PÁGINA(s) 7, 121, 182 e 275

OBSERVAÇÕES ESPECÍFICAS:

Na pág. 7 aparece a expressão: "gente de sangue limpo, com larga parentela na cidade ........."

Na pág. 121 um personagem ao se referir a protagonista, a Marqueza, fala assim: "uma pessoa agradável de sangue limpo".

Na pág. 182 uma declaração de D. Pedro I é extraída do jornal Diário Fluminense, onde fala sobre sua filha com a Marqueza: "Declaro que tive uma filha de mulher nobre, e limpa de sangue, ........."

Na pág. 275 menciona a existência do Barão Rothschild.

Os trechos constantes nas pág. 7, 121, e 182 demonstram que o Estatuto de Pureza do Sangue, datado no período colonial, ainda ecoava na sociedade brasileira, mesmo tendo sido abolido quase um século antes. 


\section{$\begin{array}{llll}\text { FICHA N }^{\circ} & 068 \quad \text { data } & 16 / 12 / 2004\end{array}$}

AUTOR: F. M. RODRIGUES ALVES FILHO

TíTULO DA OBRA: O SOCIOLOGISMO E A IMAGINAÇÃO NO ROMANCE BRASILEIRO

EDIÇÃO: $1^{\mathrm{a}}$

LOCAL DE PUBLICAÇÃO: Rio de Janeiro

EDITORA: José Olympio

DATA DA $1^{\text {a }}$ EDIÇÀO: 1938

PROSA ( $X$ ) POESIA ( )

PERSONAGEM: JUDIA（） ESTRANGEIRA（）

REFERÊNCIAS: A PERSONAGENS OU PESSOAS JUDIAS $(X)$

A PERSONAGENS OU PESSOAS ESTRANGEIRAS ( $X$ )

REFERÊNCIAS: A CULTURA JUDAICA $(X)$

A CULTURA ESTRANGEIRA ( $X$ )

REFERÊNCIAS: INTERTEXTUAIS（） TEXTUAIS（）

SE SIM, QUAIS?

CARACTERÍSTICAS DA PERSONAGEM JUDIA:

- NOME:

- CARACTERÍSTICAS FíSICAS:

A REFERÊNCIA APARECE:

- CAPÍTULO(s)

- PÁGINA(s)

OBSERVAÇÕES ESPECÍFICAS:

O autor menciona o nome de diversas personalidades, como: Jean Cocteau, Proust, Dickens e outros renomados escritores, inclusive Stefan Zweig. 
DEPARTAMENTO DE LETRAS ORIENTAIS

\section{FICHA No $069 \quad$ data $07 / 01 / 2005$}

AUTOR: ANTONIO TORRES

TÍTULO DA OBRA: VERDADES INDISCRETAS

EDIÇÃO: $2^{\mathrm{a}}$

LOCAL DE PUBLICAÇÃO: Rio de Janeiro

EDITORA: Livraria Castilho/1921

DATA DA 1ª EDIÇÀO: 1920

PROSA ( $X$ ) POESIA ( )

PERSONAGEM: JUDIA ( $X$ ) ESTRANGEIRA ( $X$ )

REFERÊNCIAS: A PERSONAGENS OU PESSOAS JUDIAS ( $X$ )

A PERSONAGENS OU PESSOAS ESTRANGEIRAS ( $X$ )

\section{REFERÊNCIAS: A CULTURA JUDAICA ( $X$ ) \\ A CULTURA ESTRANGEIRA ( $X$ )}

REFERÊNCIAS: INTERTEXTUAIS（） TEXTUAIS ( X )

SE SIM, QUAIS?

Da obra Pamphlet des Pamphlets do autor Paul Louis Courier e da obra Princesa Arminda de Baudelaire

\section{CARACTERÍSTICAS DA PERSONAGEM JUDIA:}

- NOME: Sophia Klein

- CARACTERÍSTICAS FÍSICAS: fala polaco o autor deduz que o nome Klein deve ser alemão e portanto trata-se de uma judia alemã, era proprietária de uma pensão na Rua do Catete, "anda com um pé na rua da Amargura e outro na polícia."

\section{A REFERÊNCIA APARECE:}

- CAPÍtulO(s) Moeda Falsa e Paradoxo; Edouard Drumont; A Política e o Espiritismo; A Desvantagem do Nome

- $\quad$ PÁGINA(s) 15,16, 35, 47, 48, 49, 87, 88,123,124, 139, 178, 179, 180 e 189 à 195

OBSERVAÇÕES ESPECÍFICAS: O livro é composto por crônicas publicadas em jornais da época. Nas pág. 15 e 16 fala de Jesus Cristo como um judeu e conta a passagem bíblica sobre "dar a Cesar o que é de Cesar", sutilmente fala que os judeus só pensam em dinheiro. Na pág. 35 fala sobre Torquemada e suas maldades que praticava contra os judeus. Na pág. 47 comenta sobre o livro La France Juive de Edouard Drumont, uma obra que fala sobre os banqueiros judeus, políticos que se vendiam aos judeus entre outros comentários. Nas pág. 87 e 88 levanta a questão sobre a inquisição.

A outras referências nas demais páginas citadas, destaque para o capítulo A Desvantagem do Nome, onde o autor cria uma persongem judia, mesmo comparando as judias com prostitutas e falando da prostituição no Rio de Janeiro.

Destaque também na página 179, onde o judaismo está ao lado do espiritismo e islamismo, todos considerados como seitas e não como religiões 


\section{$\begin{array}{lll}\text { FICHA N }^{\circ} & 070 \quad \text { data } 06 / 05 / 2005\end{array}$}

AUTOR: VÁRIOS (35 AUTORES)

TÍTULO DA OBRA: POR QUE SER ANTI-SEMITA? UM INQUÉRITO ENTRE INTELLECTUAIS BRASILEIROS

EDIÇÃO: $1^{\mathrm{a}}$

LOCAL DE PUBLICAÇÃO: Rio de Janeiro

EDITORA: Civilização Brasileira

DATA DA $1^{\text {a }}$ EDIÇÀO: 1933

PROSA ( $X$ ) POESIA ( )

PERSONAGEM: JUDIA（） ESTRANGEIRA（）

REFERÊNCIAS: A PERSONAGENS OU PESSOAS JUDIAS ( $X$ )

A PERSONAGENS OU PESSOAS ESTRANGEIRAS ( $X$ )

REFERÊNCIAS: A CULTURA JUDAICA ( $X$ )

A CULTURA ESTRANGEIRA ( $X$ )

REFERÊNCIAS: INTERTEXTUAIS（）TEXTUAIS（）

SE SIM, QUAIS?

\section{CARACTERÍSTICAS DA PERSONAGEM JUDIA:}

- NOME:

- CARACTERÍSTICAS FÍSICAS:

\section{A REFERÊNCIA APARECE:}

- CAPÍtulo(s) todos

- PÁGINA(s) todas

\section{OBSERVAÇÕES ESPECÍFICAS:}

O livro é composto de pequenos textos que relatam o anti-semitismo alemão, o ressurgimento da barbárie e tentam explicar ao leitor o porque de tantas perseguições. Os textos possuem caráter satírico, explicativo, sociológico, histórico e antropológico. Cada autor utilizou deu ao seu texto a característica desejada, alguns autores citaram personalidades como Émile Zolá, S. Zweig, Spinoza, entre outras.

$\mathrm{Na}$ página seguinte há uma propaganda do livro, feita pela própria editora, onde constam os nomes dos autores. O curioso é que autores como Humberto de Campos e Menotti Del Picchia, anteriormente escreveram textos depreciativos ou contrários aos judeus, Del Picchia fez parte do Grupo Ordem, ligado a Plínio Salgado e Gustavo Barroso.

Na pág. 118 Galeão Coutinho conta sobre os judeus na Frota de Cabral e de Vasco da Gama e mas adiante nas pág. 253 à 257, Silveira Bueno fala da origem judaica das populações de São Paulo e Pernambuco. 


FICHA No 071 data $26 / 08 / 2005$

AUTOR: ALFREDO ELLIS JUNIOR

TÍTULO DA OBRA: POPULAÇÕES PAULISTAS

EDIÇÃO: $1^{\mathrm{a}}$

LOCAL DE PUBLICAÇÃO: São Paulo

EDITORA: Cia. Editora Nacional

DATA DA $1^{\text {a }}$ EDIÇÀO: 1934

PROSA (X) POESIA ( )

PERSONAGEM: JUDIA（） ESTRANGEIRA（）

REFERÊNCIAS: A PERSONAGENS OU PESSOAS JUDIAS ( )

A PERSONAGENS OU PESSOAS ESTRANGEIRAS $(X)$

REFERÊNCIAS: A CULTURA JUDAICA ( $X$ )

A CULTURA ESTRANGEIRA $(X)$

REFERÊNCIAS: INTERTEXTUAIS（） TEXTUAIS ( $X$ )

SE SIM, QUAIS?

Do Conde De Gobineau em sua teoria sobre a extinção dos negros

CARACTERÍSTICAS DA PERSONAGEM JUDIA:

- NOME:

- CARACTERÍSTICAS FÍSICAS:

A REFERÊNCIA APARECE:

- CAPÍTULO(s)

- PÁGINA(s) 12, 56, 63,64, 92, 208 e 229

OBSERVAÇÕES ESPECÍFICAS:

Na pág 12 aparecem as palavras semita e judéa; na pág. 56 exemplifica o judeu como um tipo humano, falando que existem judeus loiros, morenos e negros.

Destaque para página 229 onde comenta que Nova lorque é a cidade mais judaica do mundo. 
AUTOR: MARCIO CAMPOS LIMA

TÍTULO DA OBRA: OS JUDEUS NA ALEMANHA: NO MOMENTO ACTUAL EDIÇÃO: $1^{\mathrm{a}}$

LOCAL DE PUBLICAÇÃO: Rio de Janeiro

EDITORA: Flores \& Mano

DATA DA $1^{\text {a }}$ EDIÇÀO: 1933

PROSA ( $X$ ) POESIA ( )

PERSONAGEM: JUDIA（） ESTRANGEIRA（）

REFERÊNCIAS: A PERSONAGENS OU PESSOAS JUDIAS $(X)$

A PERSONAGENS OU PESSOAS ESTRANGEIRAS $(X)$

REFERÊNCIAS: A CULTURA JUDAICA ( $X$ )

A CULTURA ESTRANGEIRA $(X)$

REFERÊNCIAS: INTERTEXTUAIS（） TEXTUAIS ( $X$ )

SE SIM, QUAIS?

De Hitler e do Conde de Gobineau

CARACTERÍSTICAS DA PERSONAGEM JUDIA:

- NOME:

- CARACTERÍSTICAS FÍSICAS:

A REFERÊNCIA APARECE:

- CAPÍTULO(s) todos

- PÁGINA(s) todas

OBSERVAÇÕES ESPECÍFICAS:

O livro é composto por vários textos escritos por autores diferentes e reunidos por Márcio Campos Lima, todos os textos falam contra a perseguição que se processava, na época, contra os judeus, contra o nazismo e sua propaganda que já estava disseminada na imprensa brasileira.

Além do Autor/organizador estào presentes na obra: Coelho Netto, Gilberto Amado, Afrânio Peixoto, e outros. 
AUTOR: J. CABRAL

TÍTULO DA OBRA: A QUESTÃO JUDAICA

EDIÇÃO:

LOCAL DE PUBLICAÇÃO: Porto Alegre

EDITORA: Globo

DATA DA $1^{\text {a }}$ EDIÇÀO: 1937

PROSA ( $X$ ) POESIA ( )

PERSONAGEM: JUDIA（） ESTRANGEIRA（）

REFERÊNCIAS: A PERSONAGENS OU PESSOAS JUDIAS ( $X$ ) A PERSONAGENS OU PESSOAS ESTRANGEIRAS $(X)$

REFERÊNCIAS: A CULTURA JUDAICA ( $X$ ) A CULTURA ESTRANGEIRA（ )

REFERÊNCIAS: INTERTEXTUAIS ( $X$ ) TEXTUAIS $(X)$

SE SIM, QUAIS?

Há várias referências textuais e intertextuais de diversos autores e obras, especialmenteas teorias antisemitas propagadas na época (1937), utilizadas para dar base e justificar as teses defendidas pelo autor.

\section{CARACTERÍSTICAS DA PERSONAGEM JUDIA:}

- NOME:

- CARACTERÍSTICAS FÍSICAS:

\section{A REFERÊNCIA APARECE:}

- CAPÍTULO(s) todos

- PÁGINA(s) todas

\section{OBSERVAÇÕES ESPECÍFICAS:}

O livro conta com o prefácio escrito por Gustavo Barroso, o autor defende o facismo e o nazismo abertamente.

No capítulo XII o autor comenta, especificamente, sobre o livro Os Protocolos dos Sábios do Sião e no capítulo XIX aborda sobre os judeus no Brasil, com estatística sobre o número de judeus no Brasil. 
AUTOR: JULIA LOPES DE ALMEIDA

TÍTULO DA OBRA: A ISCA

EDIÇÃO: $1^{\text {a }}$

LOCAL DE PUBLICAÇÃO: Rio de Janeiro

EDITORA: EDITORA E LIVRARIA LEITE RIBEIRO

DATA DA $1^{\text {a }}$ EDIÇÀO: 1922

PROSA ( $X$ ) POESIA ( )

PERSONAGEM: JUDIA（） ESTRANGEIRA（）

REFERÊNCIAS: A PERSONAGENS OU PESSOAS JUDIAS ( ) A PERSONAGENS OU PESSOAS ESTRANGEIRAS（）

REFERÊNCIAS: A CULTURA JUDAICA（ ) A CULTURA ESTRANGEIRA $(X)$

REFERÊNCIAS: INTERTEXTUAIS（） TEXTUAIS（）

SE SIM, QUAIS?

CARACTERÍSTICAS DA PERSONAGEM JUDIA:

- NOME:

- CARACTERÍSTICAS FÍSICAS:

A REFERÊNCIA APARECE:

- CAPÍTULO(s)

- PÁGINA(s)

OBSERVAÇÕES ESPECÍFICAS:

O livro e composto por 4 novelas, entre elas a que intitula a obra e: $O$ Homem que Olha para Dentro, O Laço Azul e O Dedo do Velho.

Há algumas referências relacionadas com a cultura francesa, mas o destaque fica ao comentário de que os argentinos (já naquela época), chamavam os brasileiros de macaquitos (ver pág. 045). 
AUTOR: CATULLO CEARENSE

TíTULO DA OBRA: ALMA DO SERTÃO: DESAFIOS A MULHER JULGADA PELOS HOMENS

EDIÇÃO:

LOCAL DE PUBLICAÇÃO: Rio de Janeiro

EDITORA: Livraria Editora Leite Ribeiro, Freitas Bastos \& Cia.

DATA DA $1^{\text {a }}$ EDIÇÀO: 1928

PROSA ( ) POESIA (X)

PERSONAGEM: JUDIA（） ESTRANGEIRA（）

REFERÊNCIAS: A PERSONAGENS OU PESSOAS JUDIAS ( ) A PERSONAGENS OU PESSOAS ESTRANGEIRAS（）

REFERÊNCIAS: A CULTURA JUDAICA ( )

A CULTURA ESTRANGEIRA（）

REFERÊNCIAS: INTERTEXTUAIS（） TEXTUAIS（）

SE SIM, QUAIS?

CARACTERÍSTICAS DA PERSONAGEM JUDIA:

- NOME:

- CARACTERÍSTICAS FÍSICAS:

A REFERÊNCIA APARECE:

- CAPÍTULO(s)

- PÁGINA(s)

OBSERVAÇÕES ESPECÍFICAS:

Não há elementos a serem estudados que sejam importantes para a pesquisa.

Destaque para a escrita que obedece o modo de falar do sertão nordestino, sem se prender as regras de ortografia e/ou gramaticais.

Os versos são feitos para o gênero "desafio", comum no nordeste, onde dois interlocutores fazem perguntas e respondem mutuamente sobre um determinado tema. 
DEPARTAMENTO DE LETRAS ORIENTAIS

$\begin{array}{lll}\text { FICHA N }^{\circ} & 076 \quad \text { data } 12 / 11 / 2005\end{array}$

AUTOR: CARLOS CAVACO

TÍTULO DA OBRA: MUSA VERMELHA

EDIÇÃO:

LOCAL DE PUBLICAÇÃO: São Paulo

EDITORA: C. Teixeira \& Cia. (Livraria Teixeira)

DATA DA 1ª EDIÇÀO: 1928

PROSA ( ) POESIA (X)

PERSONAGEM: JUDIA（） ESTRANGEIRA（）

REFERÊNCIAS: A PERSONAGENS OU PESSOAS JUDIAS ( )

A PERSONAGENS OU PESSOAS ESTRANGEIRAS ( $X$ )

REFERÊNCIAS: A CULTURA JUDAICA（）

A CULTURA ESTRANGEIRA ( $X$ )

REFERÊNCIAS: INTERTEXTUAIS（）TEXTUAIS（）

SE SIM, QUAIS?

CARACTERÍSTICAS DA PERSONAGEM JUDIA:

- NOME:

- CARACTERÍSTICAS FÍSICAS:

A REFERÊNCIA APARECE:

- CAPÍTULO(s)

- PÁGINA(s) 117 e 118

OBSERVAÇÕES ESPECÍFICAS:

O livro é composto de poesias que foram escritas pelo autor entre os anos de 1918 e 1922, sendo a maioria escrita no ano de 1920. Nas páginas 117 e 118, aparecerem os seguintes versos:

pág. 117 - "É que essa raça filha de Israel, honrada e pura da cabeça aos pés, aprendeu nas doutrinas de Moysés que da palavra Fé fizeram fél."

pág. 118 - "São esses, judas, os que prejudicam a grandeza da causa da tua seita. são esses afinal, que sacrificam uma doutrina simples e perfeita." 
AUTOR: RONALD DE CARVALHO

TÍTULO DA OBRA: TODA A AMÉRICA

EDIÇÃO:

LOCAL DE PUBLICAÇÃO: São Paulo/1935

EDITORA: Não consta o nome

DATA DA $1^{a}$ EDIÇÀO: Não consta a data

PROSA ( ) POESIA ( $X)$

PERSONAGEM: JUDIA（） ESTRANGEIRA（）

REFERÊNCIAS: A PERSONAGENS OU PESSOAS JUDIAS ( )

A PERSONAGENS OU PESSOAS ESTRANGEIRAS $(X)$

REFERÊNCIAS: A CULTURA JUDAICA（ )

A CULTURA ESTRANGEIRA（）

REFERÊNCIAS: INTERTEXTUAIS（） TEXTUAIS（）

SE SIM, QUAIS?

CARACTERÍSTICAS DA PERSONAGEM JUDIA:

- NOME:

- CARACTERÍSTICAS FÍSICAS:

A REFERÊNCIA APARECE:

- CAPÍTULO(s)

- PÁGINA(s)

OBSERVAÇÕES ESPECÍFICAS:

Não há elementos a serem estudados que sejam importantes para a pesquisa.

Destaque apenas para o fato das poesias serem dedicadas aos amigos do escritor, entre eles: Mario de Andrade, Ruy Ribeiro Couto, Diego Rivera e outros. Algumas poesias são datadas entre 1923 e 1924 


\section{FICHA N $^{\circ} \quad 078 \quad$ data $30 / 11 / 2005$}

AUTOR: OLAVO BILAC

TÍTULO DA OBRA: POESIAS

EDIÇÃO: $8^{\mathrm{a}}$

LOCAL DE PUBLICAÇÃO: Rio de Janeiro

EDITORA: Livraria Francisco Alves/1921

DATA DA $1^{a}$ EDIÇÀO: Não consta a data

PROSA ( ) POESIA (X)

PERSONAGEM: JUDIA（） ESTRANGEIRA（）

REFERÊNCIAS: A PERSONAGENS OU PESSOAS JUDIAS ( ) A PERSONAGENS OU PESSOAS ESTRANGEIRAS ( $X$ )

REFERÊNCIAS: A CULTURA JUDAICA（ ) A CULTURA ESTRANGEIRA ( $X$ )

REFERÊNCIAS: INTERTEXTUAIS（） TEXTUAIS ( $X$ )

SE SIM, QUAIS?

Da Bíblia e do romance Romeu e Julieta de Sheakespeare são intertextuais e Textuais de Dante Alighieri

\section{CARACTERÍSTICAS DA PERSONAGEM JUDIA:}

- NOME:

- CARACTERÍSTICAS FÍSICAS:

A REFERÊNCIA APARECE:

- CAPÍTULO(s)

- PÁGINA(s) 237 e 334

\section{OBSERVAÇÕES ESPECÍFICAS:}

O livro é composto de poesias como sugere o título e algumas delas são oferecidas para grandes autores como: Bocage e Goethe.

Na pág. 237 há um poema intitulado Israel, que fala em terra prometida, jeovah, um dos trechos é este: "A tua raça corre os desastres da vida, insultada na patria e odiada no estrangeiro!"

Na pág. 334 o poema se chama A Rainha de Sabá, há no início um curto trecho transcrito da Bíblia e a poesia possui intertextualidade com passagens bíblicas. 
AUTOR: CESIDIO AMBROGI

TÍTULO DA OBRA: POEMAS VERMELHOS: uma tentativa de poesia social EDIÇÃO:

LOCAL DE PUBLICAÇÃO: Curitiba

EDITORA: Guaíra Limitada

DATA DA $1^{\text {a }}$ EDIÇÀO:

PROSA（） POESIA（ )

PERSONAGEM: JUDIA（） ESTRANGEIRA（）

REFERÊNCIAS: A PERSONAGENS OU PESSOAS JUDIAS ( ) A PERSONAGENS OU PESSOAS ESTRANGEIRAS（）

REFERÊNCIAS: A CULTURA JUDAICA（） A CULTURA ESTRANGEIRA（）

REFERÊNCIAS: INTERTEXTUAIS（） TEXTUAIS（）

SE SIM, QUAIS?

CARACTERÍSTICAS DA PERSONAGEM JUDIA:

- NOME:

- CARACTERÍSTICAS FÍSICAS:

A REFERÊNCIA APARECE:

- CAPÍTULO(s)

- PÁGINA(s)

OBSERVAÇÕES ESPECÍFICAS:

Não há elementos a serem estudados que sejam importantes para a pesquisa.

Com relação ao ano de publicação não consta qualquer referência na obra, porém no levantamento feito na Biblioteca Central da FFLCH, o livro aparece como tendo sido publicado em 1923. 


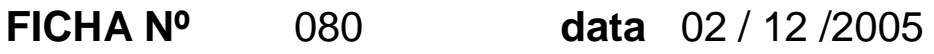

AUTOR: BENEDITO LUÍS RODRIGUES DE ABREU

TÍTULO DA OBRA: A SALA DOS PASSOS PERDIDOS

EDIÇÃO:

LOCAL DE PUBLICAÇÃO: São Paulo/1924

EDITORA: Cia. Graphico-Editora Monteiro Lobato

DATA DA $1^{\text {a }}$ EDIÇÀO:

PROSA ( ) POESIA ( $X)$

PERSONAGEM: JUDIA（） ESTRANGEIRA（）

REFERÊNCIAS: A PERSONAGENS OU PESSOAS JUDIAS ( $X$ )

A PERSONAGENS OU PESSOAS ESTRANGEIRAS $(X)$

REFERÊNCIAS: A CULTURA JUDAICA ( $X$ )

A CULTURA ESTRANGEIRA ( $X$ )

REFERÊNCIAS: INTERTEXTUAIS ( $X$ ) TEXTUAIS ( )

SE SIM, QUAIS?

Com o Cântico dos Cânticos de Salomão

CARACTERÍSTICAS DA PERSONAGEM JUDIA:

- NOME:

- CARACTERÍSTICAS FÍSICAS:

A REFERÊNCIA APARECE:

- CAPÍTULO(s)

- PÁGINA(s) 10, 11, 99 a 103, 128 e 131

OBSERVAÇÕES ESPECÍFICAS:

Na pág. 10 e 11 aparece o Rei Salomão.

Na pág. 99 o poema é intitulado Schahrazade.

Na pág. 103 aparece a figura de Sulamita do Cântico dos Cânticos.

Na pág. 128 o poema chama-se Jerusalém.

No poema que consta na pág. 131, tem um verso que diz: "eu creio em kabalas... ..." 


\section{FICHA No $081 \quad$ data $03 / 12 / 2005$}

AUTOR: ARISTÊO SEIXAS

TÍTULO DA OBRA: PÔR DO SOL

EDIÇÃO:

LOCAL DE PUBLICAÇÃO: São Paulo/1924

EDITORA: Cia. Graphico-Editora Monteiro Lobato

DATA DA $1^{\text {a }}$ EDIÇÀO:

PROSA ( ) POESIA (X)

PERSONAGEM: JUDIA（） ESTRANGEIRA（）

REFERÊNCIAS: A PERSONAGENS OU PESSOAS JUDIAS ( ) A PERSONAGENS OU PESSOAS ESTRANGEIRAS ( $X$ )

REFERÊNCIAS: A CULTURA JUDAICA ( $X$ )

A CULTURA ESTRANGEIRA（）

REFERÊNCIAS: INTERTEXTUAIS（） TEXTUAIS（）

SE SIM, QUAIS?

CARACTERÍSTICAS DA PERSONAGEM JUDIA:

- NOME:

- CARACTERÍSTICAS FÍSICAS:

A REFERÊNCIA APARECE:

- CAPÍTULO(s)

- PÁGINA(s)

OBSERVAÇÕES ESPECÍFICAS:

Não há elementos a serem estudados que sejam importantes para a pesquisa. Exceto o fato de aparecer na pág. 93 a expressão "terra prometida" e na pág. 35, no poema No Éden, aparecer a expressão "paraíso de Adão". 


\section{FICHA N $^{\circ} 082 \quad$ data $04 / 12 / 2005$}

AUTOR: RUI RIBEIRO COUTO

TíTULO DA OBRA: POEMETOS DE TERNURA E DE MELANCOLIA: 1920 - 1922 EDIÇÃO:

LOCAL DE PUBLICAÇÃO: São Paulo

EDITORA: Monteiro Lobato \& Cia.

DATA DA $1^{\text {a }}$ EDIÇÀO: 1924

PROSA ( ) POESIA (X)

PERSONAGEM: JUDIA（） ESTRANGEIRA（）

REFERÊNCIAS: A PERSONAGENS OU PESSOAS JUDIAS ( ) A PERSONAGENS OU PESSOAS ESTRANGEIRAS $(X)$

REFERÊNCIAS: A CULTURA JUDAICA（）

A CULTURA ESTRANGEIRA $(X)$

REFERÊNCIAS: INTERTEXTUAIS（） TEXTUAIS（）

SE SIM, QUAIS?

CARACTERÍSTICAS DA PERSONAGEM JUDIA:

- NOME:

- CARACTERÍSTICAS FÍSICAS:

A REFERÊNCIA APARECE:

- CAPÍTULO(s)

- PÁGINA(s)

OBSERVAÇÕES ESPECÍFICAS:

Não há elementos a serem estudados que sejam importantes para a pesquisa.

Único destaque é para a poesia chamada Milonguita, flor de Buenos Aires, que comenta sobre uma prostituta, portenha e viciada em morfina. 


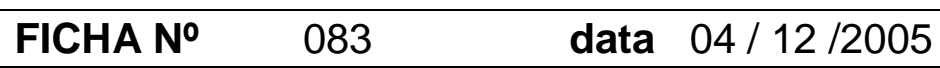

AUTOR: M. PEREIRA FORTES

TÍTULO DA OBRA: CANTARES DA MINHA TERRA: VERSOS GAÚCHOS EDIÇÃO:

LOCAL DE PUBLICAÇÃO: São Paulo

EDITORA: Livraria Rio Grandense

DATA DA $1^{\text {a }}$ EDIÇÀO: 1924

PROSA ( ) POESIA (X)

PERSONAGEM: JUDIA（） ESTRANGEIRA（）

REFERÊNCIAS: A PERSONAGENS OU PESSOAS JUDIAS ( ) A PERSONAGENS OU PESSOAS ESTRANGEIRAS（）

REFERÊNCIAS: A CULTURA JUDAICA ( )

A CULTURA ESTRANGEIRA $(X)$

REFERÊNCIAS: INTERTEXTUAIS（） TEXTUAIS（）

SE SIM, QUAIS?

CARACTERÍSTICAS DA PERSONAGEM JUDIA:

- NOME:

- CARACTERÍSTICAS FÍSICAS:

A REFERÊNCIA APARECE:

- CAPÍTULO(s)

- PÁGINA(s)

OBSERVAÇÕES ESPECÍFICAS:

Não há elementos a serem estudados que sejam importantes para a pesquisa.

Exceto nas páginas 98 à 102 onde aparece uma poesia escrita em espanhol. 


\section{FICHA N $^{\circ} \quad 084 \quad$ data $05 / 12 / 2005$}

AUTOR: BELMIRO BRAGA

TÍTULO DA OBRA: ROSAS: VERSOS

EDIÇÃO: $4^{\mathrm{a}}$

LOCAL DE PUBLICAÇÃO: São Paulo/1924

EDITORA: Cia. Teixeira \& C. - Editores

DATA DA 1 ${ }^{\text {a }}$ EDIÇÀO: 1911

PROSA ( ) POESIA (X)

PERSONAGEM: JUDIA（） ESTRANGEIRA（）

REFERÊNCIAS: A PERSONAGENS OU PESSOAS JUDIAS ( ) A PERSONAGENS OU PESSOAS ESTRANGEIRAS（）

REFERÊNCIAS: A CULTURA JUDAICA（）

A CULTURA ESTRANGEIRA ( $X$ )

REFERÊNCIAS: INTERTEXTUAIS ( $X$ ) TEXTUAIS ( )

SE SIM, QUAIS?

De textos de Victor Hugo, De Coppée e outros autores franseces menos conhecidos

CARACTERÍSTICAS DA PERSONAGEM JUDIA:

- NOME:

- CARACTERÍSTICAS FÍSICAS:

A REFERÊNCIA APARECE:

- CAPÍTULO(s)

- PÁGINA(s)

OBSERVAÇÕES ESPECÍFICAS:

Não há elementos a serem estudados que sejam relevantes para a pesquisa. 


\section{FICHA N $^{\circ} 085 \quad$ data $05 / 12 / 2005$}

AUTOR: FELIPPE D'OLIVEIRA

TÍTULO DA OBRA: LANTERNA VERDE

EDIÇÃO: $1^{\mathrm{a}}$

LOCAL DE PUBLICAÇÃO: Rio de Janeiro

EDITORA: Pimenta de Mello \& Cia.

DATA DA $1^{\text {a }}$ EDIÇÀO: 1926

PROSA ( ) POESIA (X)

PERSONAGEM: JUDIA（） ESTRANGEIRA（）

REFERÊNCIAS: A PERSONAGENS OU PESSOAS JUDIAS ( ) A PERSONAGENS OU PESSOAS ESTRANGEIRAS ( )

REFERÊNCIAS: A CULTURA JUDAICA（）

A CULTURA ESTRANGEIRA ( $X$ )

REFERÊNCIAS: INTERTEXTUAIS（） TEXTUAIS（）

SE SIM, QUAIS?

CARACTERÍSTICAS DA PERSONAGEM JUDIA:

- NOME:

- CARACTERÍSTICAS FÍSICAS:

A REFERÊNCIA APARECE:

- CAPÍTULO(s)

- PÁGINA(s)

OBSERVAÇÕES ESPECÍFICAS:

Não há elementos a serem estudados que sejam relevantes para a pesquisa. 


\section{FICHA N $^{\circ} 086 \quad$ data $06 / 12 / 2005$}

AUTOR: BENEDITO LUÍS RODRIGUES DE ABREU

TÍTULO DA OBRA: CASA DESTELHADA

EDIÇÃO:

LOCAL DE PUBLICAÇÃO: São Paulo/1927

EDITORA: Helios Limitada

DATA DA $1^{\text {a }}$ EDIÇÀO:

PROSA（） POESIA ( $X$ )

PERSONAGEM: JUDIA（） ESTRANGEIRA（）

REFERÊNCIAS: A PERSONAGENS OU PESSOAS JUDIAS ( ) A PERSONAGENS OU PESSOAS ESTRANGEIRAS（）

REFERÊNCIAS: A CULTURA JUDAICA（）

A CULTURA ESTRANGEIRA（）

REFERÊNCIAS: INTERTEXTUAIS（） TEXTUAIS（）

SE SIM, QUAIS?

CARACTERÍSTICAS DA PERSONAGEM JUDIA:

- NOME:

- CARACTERÍSTICAS FÍSICAS:

A REFERÊNCIA APARECE:

- CAPÍTULO(s)

- PÁGINA(s)

OBSERVAÇÕES ESPECÍFICAS:

Não há elementos a serem estudados que sejam relevantes para a pesquisa. 


\section{FICHA N $^{\circ} \quad 087 \quad$ data $07 / 12 / 2005$}

AUTOR: PLÍNIO SALGADO

TÍTULO DA OBRA: O EXTRANGEIRO

EDIÇÃO:

LOCAL DE PUBLICAÇÃO: Rio de Janeiro/1936

EDITORA: José Olympio

DATA DA $1^{\text {a }}$ EDIÇÀO:

PROSA ( $X$ ) POESIA ( )

PERSONAGEM: JUDIA $(X)$ ESTRANGEIRA $(X)$

REFERÊNCIAS: A PERSONAGENS OU PESSOAS JUDIAS $(X)$

A PERSONAGENS OU PESSOAS ESTRANGEIRAS $(X)$

REFERÊNCIAS: A CULTURA JUDAICA（）

A CULTURA ESTRANGEIRA ( $X$ )

REFERÊNCIAS: INTERTEXTUAIS（） TEXTUAIS（）

SE SIM, QUAIS?

\section{CARACTERÍSTICAS DA PERSONAGEM JUDIA:}

- NOME: Fritz Nagel

- CARACTERÍSTICAS FÍSICAS: É um personagem bem secundário que aparece num curto trecho, não aparece características físicas, único elemento que aparece é que era Bávaro.

\section{A REFERÊNCIA APARECE:}

- CAPÍtUlo(s)

- PÁGINA(s) 95 e 96

\section{OBSERVAÇÕES ESPECÍFICAS:}

O livro é composto de pequenos contos que se entrelaçam e seguem um fio temporal. Há vários personagens italianos, um árabe, um espanhol e todos eles são esteriotipados.

Na pág. 21 aparece o comentário: "Para a lavoura, os russos não prestam. Vadios e insolentes. Além do mais anarchistas."

Na pág. 95 comenta sobre os judeus: "Travou conhecimento com diversos judeus que se diziam russos e allemães. Tinham garras de vampiros e olhos vulturino." 


FICHA No $^{\circ} 088 \quad$ data $08 / 12 / 2005$

AUTOR: MENOTTI DEL PICCHIA, PLÍNIO SALGADO E CASSIANO RICARDO TÍTULO DA OBRA: O CURUPIRA E O CARÃO EDIÇÃO:

LOCAL DE PUBLICAÇÃO: São Paulo/1927

EDITORA: Helios Limitada

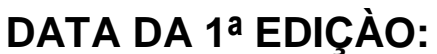

PROSA ( $X$ ) POESIA ( )

PERSONAGEM: JUDIA（） ESTRANGEIRA（）

REFERÊNCIAS: A PERSONAGENS OU PESSOAS JUDIAS ( ) A PERSONAGENS OU PESSOAS ESTRANGEIRAS $(X)$

REFERÊNCIAS: A CULTURA JUDAICA（）

A CULTURA ESTRANGEIRA（）

REFERÊNCIAS: INTERTEXTUAIS（） TEXTUAIS（）

SE SIM, QUAIS?

CARACTERÍSTICAS DA PERSONAGEM JUDIA:

- NOME:

- CARACTERÍSTICAS FÍSICAS:

A REFERÊNCIA APARECE:

- CAPÍTULO(s)

- PÁGINA(s)

OBSERVAÇÕES ESPECÍFICAS:

Não há elementos a serem estudados que sejam importantes para a pesquisa.

Destaque para o fato do livro ser compostos de artigos publicados entre 1922 e 1927, que comentam sobre a Semana de 22. 


\section{FICHA N $^{\circ} \quad 089 \quad$ data $09 / 12 / 2005$}

AUTOR: BRAZ DO AMARAL

TÍTULO DA OBRA: CARTAS E DESCRIÇÕES

EDIÇÃO:

LOCAL DE PUBLICAÇÃO: Porto/1924

EDITORA: Typographia Economica

DATA DA $1^{\mathrm{a}}$ EDIÇÀO:

PROSA ( $X$ ) POESIA ( )

PERSONAGEM: JUDIA（） ESTRANGEIRA（）

REFERÊNCIAS: A PERSONAGENS OU PESSOAS JUDIAS ( )

A PERSONAGENS OU PESSOAS ESTRANGEIRAS ( $X$ )

REFERÊNCIAS: A CULTURA JUDAICA ( )

A CULTURA ESTRANGEIRA（）

REFERÊNCIAS: INTERTEXTUAIS（） TEXTUAIS（）

SE SIM, QUAIS?

CARACTERÍSTICAS DA PERSONAGEM JUDIA:

- NOME:

- CARACTERÍSTICAS FÍSICAS:

A REFERÊNCIA APARECE:

- CAPÍTULO(s)

- PÁGINA(s)

OBSERVAÇÕES ESPECÍFICAS:

Não há elementos a serem estudados que sejam importantes para a pesquisa.

O livro tem o formato brochura e é composto por cartas escritas em Londres, pelo autor, para o Jornal de Notícias da Bahia, entre os anos de 1912 e 1921. 


FICHA No $^{\circ} 090 \quad$ data $12 / 12 / 2005$

AUTOR: ED NAVARRO DE ANDRADE

TÍTULO DA OBRA: POR AHI ALÉM: IMPRESSÕES DE VIAGEM EDIÇÃO:

LOCAL DE PUBLICAÇÃO: São Paulo/1927

EDITORA: Typ. Brasil de Rothschild \& Cia.

DATA DA $1^{\text {a }}$ EDIÇÀO:

PROSA ( $X$ ) POESIA ( )

PERSONAGEM: JUDIA（） ESTRANGEIRA（）

REFERÊNCIAS: A PERSONAGENS OU PESSOAS JUDIAS ( ) A PERSONAGENS OU PESSOAS ESTRANGEIRAS ( $X$ )

REFERÊNCIAS: A CULTURA JUDAICA ( $X$ )

A CULTURA ESTRANGEIRA $(X)$

REFERÊNCIAS: INTERTEXTUAIS（） TEXTUAIS（）

SE SIM, QUAIS?

CARACTERÍSTICAS DA PERSONAGEM JUDIA:

- NOME:

- CARACTERÍSTICAS FÍSICAS:

A REFERÊNCIA APARECE:

- CAPÍTULO(s)

- PÁGINA(s) 48 à 52 e 76 à 83

\section{OBSERVAÇÕES ESPECÍFICAS:}

Na pág. 36 aparece o comentário: "No Japão, não queriam deixar-me desembarcar sem que eu declarasse o que ia fazer à India, o que recusei terminantemente. Fiz ver a esses idiotas que, além de ser passageiro em trânsito, era representante official do único paiz do mundo em que, infelizmente, os japoneses têm entrada livre e são considerados gente".

Na pág. 51 descreve um armênio assim: "Um armênio, com todas as características da patifaria de sua raça, ..."

Nas pág. 48 à 52 e 76 à 83 fala da cidade de Jerusalém e outras cidades, da então, Palestina. Comenta sobre o Muro das Lamentações e outros locais. Não faz nenhum comentário que desabone os judeus ou a religião judaica. Será que é por conta do nome da editora? 


\section{FICHA N $^{\circ} \quad 000 \quad$ data $00 / 00 / 2000$}

AUTOR: A

TÍTULO DA OBRA: A

EDIÇÃO: $1^{\mathrm{a}}$

LOCAL DE PUBLICAÇÃO: São Paulo Rio de Janeiro

EDITORA: A

DATA DA $1^{\text {a }}$ EDIÇÀO: 19

PROSA ( $X$ ) POESIA ( )

PERSONAGEM: JUDIA $(X)$ ESTRANGEIRA $(X)$

REFERÊNCIAS: A PERSONAGENS OU PESSOAS JUDIAS $(X)$

A PERSONAGENS OU PESSOAS ESTRANGEIRAS ( $X$ )

REFERÊNCIAS: A CULTURA JUDAICA ( $X$ )

A CULTURA ESTRANGEIRA ( $X$ )

REFERÊNCIAS: INTERTEXTUAIS（） TEXTUAIS（）

SE SIM, QUAIS?

CARACTERÍSTICAS DA PERSONAGEM JUDIA:

- NOME:

- CARACTERÍSTICAS FÍSICAS:

A REFERÊNCIA APARECE:

- CAPÍTULO(s)

- PÁGINA(s)

OBSERVAÇÕES ESPECÍFICAS:

Não há elementos a serem estudados que sejam importantes para a pesquisa. 